Rodrigo Vieira Rodrigues

\title{
IDENTIFICAÇÃO E CARACTERIZAÇÃO DE MARCADORES MOLECULARES EM CARCINOMAS EPIDERMÓIDES DE CABEÇA E PESCOÇO
}

\author{
IDENTIFICATION AND CHARACTERIZATION OF \\ MOLECULAR MARKERS IN HEAD AND NECK \\ SQUAMOUS CELL CARCINOMA
}


Rodrigo Vieira Rodrigues

Versão Corrigida

\title{
IDENTIFICAÇÃO E CARACTERIZAÇÃO DE MARCADORES MOLECULARES EM CARCINOMAS EPIDERMÓIDES DE CABEÇA E PESCOÇO
}

\author{
IDENTIFICATION AND CHARACTERIZATION OF \\ MOLECULAR MARKERS IN HEAD AND NECK \\ SQUAMOUS CELL CARCINOMA
}

Tese apresentada ao Instituto de Biociências da Universidade de São Paulo, para obtenção de Título de Doutor em Ciências, na área de Biologia/Genética.

Orientadora: Eloiza Helena Tajara da Silva

São Paulo

2011 


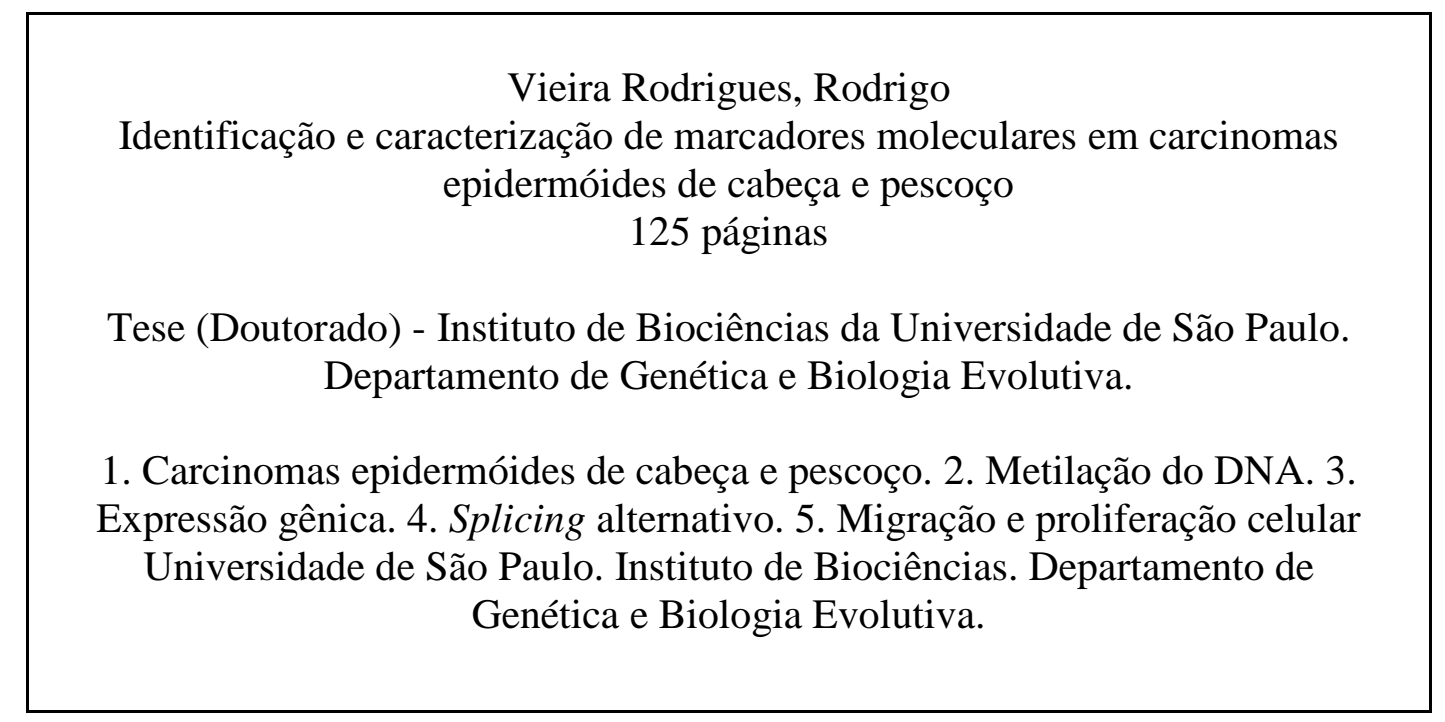

\section{Comissão Julgadora}

Prof.a. Dra. Regina Célia Mingroni-

Netto

Instituto de Biociências - USP

Prof.a. Dra. Luciana Haddad

Instituto de Biociências - USP

Prof. Dr. André Lopes Carvalho

Prof. Dr. Fábio Daumas Nunes

Hospital do Câncer de Barretos

Faculdade de Odontologia - USP

Prof.a. Dra. Eloiza Helena Tajara da Silva

Orientadora 
Dedicatória

Aos pacientes e seus familiares,

por sua coragem e determinação

na luta contra o câncer. 


\section{Agradecimentos}

À Dra. Eloiza Helena Tajara da Silva, orientadora deste trabalho, exemplo de pesquisadora, meus sinceros agradecimentos pelos ensinamentos, pelas críticas e pela oportunidade. Parabéns pela sua carreira brilhante e obrigado por tudo!

Ao Dr. Roger Chammas pela oportunidade e confiança depositadas em mim e pelas sugestões valiosas nos ensaios funcionais desenvolvidos eu seu laboratório.

Aos amigos do Grupo de Adesão Celular e Câncer (FMUSP), especialmente à Dra. Andréia Otake, Ana, Dra. Camila Machado, Camila Melo, Guilherme, Lara, Luiza, Flávia, Pedro, Moacyr, Mariana, Raimundo, Rafael, Renata, Rodrigo, Silvina, Tharcísio, Tatiane, Vanessa, pela agradável acolhida e amizade.

Ao Dr. Jean Pierre-Issa, por ter me recebido e me acolhido tão bem em seu laboratório, pela sua orientação e conselhos.

Ao Dr. Marcos Roberto Higino Estécio, pela participação ativa na realização deste trabalho e pela amizade presente em grande parte deste trabalho.

Aos amigos do laboratório do Dr. Issa pela amizade, carinho, vivência, compreensão. Agradeço em especial ao Dr. Jumpei Yamazaki, Hai Long, Dr. Tomomitsu Tahara, Saira Ahmed, Chunlei Jin, Dr. Woonbok Chung e Dr. Jaroslav Jelinek.

À Dra. Anamaria Aranha Carmargo pela contribuição essencial para o desenvolvimento deste trabalho e pela disponibilidade em me receber em seu laboratório.

Aos amigos do laboradório de Biologia Molecular e Genômica do Ludwig Institute for Cancer Research - São Paulo. Especialmente ao Ricardo P. Moura pela ajudas nos experimentos envolvendo PCR-MSP. 
Aos pesquisadores que participaram do projeto temático de metilação em câncer de cabeça e pescoço. Especialmente ao Dr. Sandro Roberto Valentini, à Dra. Dirce Carraro, ao Dr. Cleslei Zanelli, à Dra. Marília Calmon, à Dra Paula Rahal e ao Dr. Wilson Araújo da Silva Júnior.

Ao Dr. Fábio Daumas Nunes e aos membros de seu laboratório, especialmente à Dra. Camila Rondini e à Fernanda Rodrigues

À Dra. Monica Beatriz Mathor, à Dra. Fátima Klingbeil e à Daniele Yoshito, pela ajuda nas culturas de queratinócitos primários bucais.

Ao Instituto de Biociências da Universidade de São Paulo - IB/USP, por me propiciar uma excelente formação acadêmica.

Aos coordenadores e funcionários do programa de pós-graduação em Genética do Instituto de Biociências da USP, em especial à Dra Regina Célia Mingoni-Netto, à Dra. Célia Priszkulnik Koiffmann, à Deisy Santos de Morais, Érika Harumi Takamoto de Camargo e Helder Rossi Santos Souza pela competência e disposição, auxiliando sempre que necessário.

Aos pesquisadores do grupo GENCAPO (Head and Neck Genome Project), responsáveis pela coleta das amostras biológicas e respectivas análises patológicas, além de disponibilizarem os dados dos pacientes.

Aos pacientes, que voluntariamente doaram as amostras para a pesquisa científica.

Aos amigos do Laboratório de Marcadores Moleculares e Bioinformática Médica (LMMBM) pelas conversas, vivência e compreensão. Agradeço ao Caíque, Dr. Ulises Mancini, Dr. Nelson Silveira, Flávio, Tiago, Dra. Andréia Leopoldino, Dra. Flávia Lisoni, Giovana, Fernanda, Bianca, Natália, Juliana, Jaqueline e Alessandra.

À FAPESP (Fundação de Amparo à Pesquisa Científica do Estado de São Paulo) pelo financiamento deste trabalho. 
Aos meus grandes amigos Eder Públio, Pedro Guimarães, Cíntia Milani, Sebastião e Conceição Abreu, Natália, Letícia, Lucas Guerra, Fernandes e Denise Inoue, Maria Arpálice e à minha prima Bianca Pinheiro, por me receberem de braços abertos em São Paulo, pelos momentos de alegria e pelo seu carinho.

Aos eternos amigos Mário Sérgio Spinelli, Breno Motta, Rodrigo Vela, Alex Braccialli, Gustavo Gregoracci, Diego Alonso, Aripuanã Watanabe, Marcelo Miranda, Pablo Calderero, Edenilson Públio, Rodrigo Carlotti, José Licurgo, Edenilson Públio, Marcelo Piloni e Rodrigo Pradella.

Aos meus pais Waldomiro e Alaíde, à minhas irmãs Daniela e Isis e à minha sobrinha Valentina, por todo apoio que me deram e fizeram com que fosse possível a concretização de mais essa etapa em minha vida.

À minha namorada Thais de Almeida Prado Inoue por todo apoio, pela compreensão da ausência de seis meses, pelo companheirismo, pelo incentivo e pelo amor que recebo.

A todas as pessoas que, direta ou indiretamente, contribuíram para o desenvolvimento desta Tese de Doutorado. 


\section{SUMÁRIO}

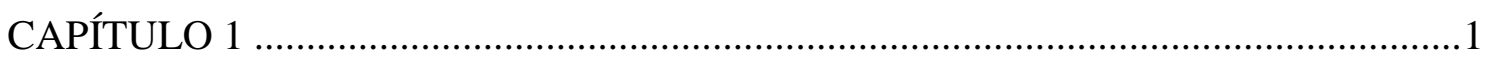

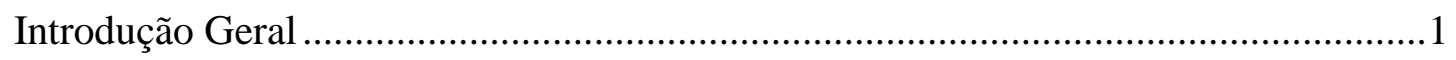

Carcinoma epidermóide de cabeça e pescoço .......................................................

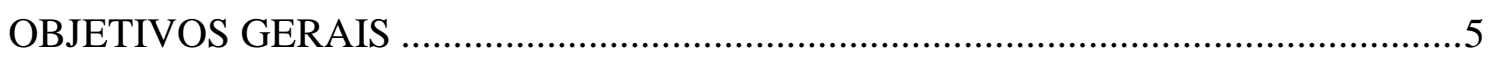

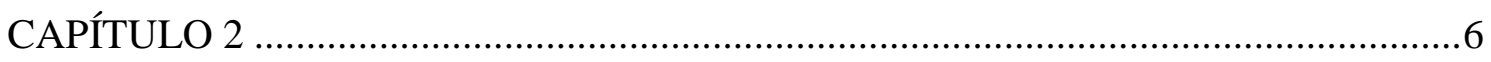

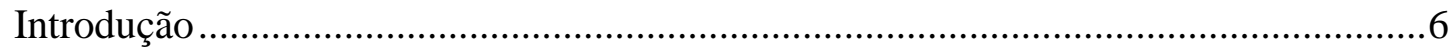

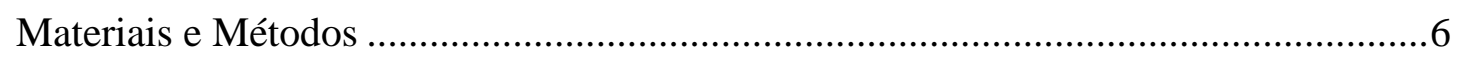

Resultados e Discussão....................................................................................

Epigenetic silencing of $C R A B P 2$ and $M X 1$ in head and neck tumors.......................... 8

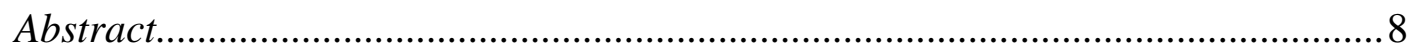

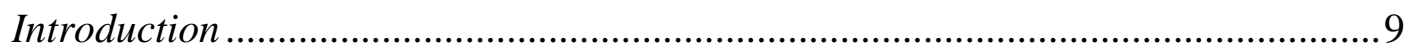

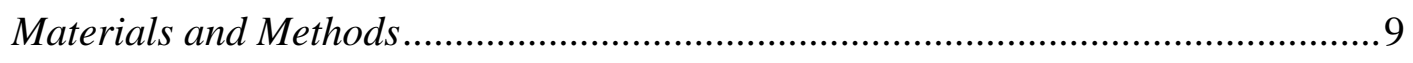

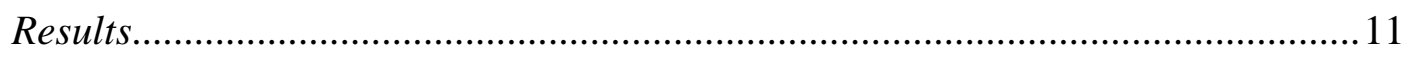

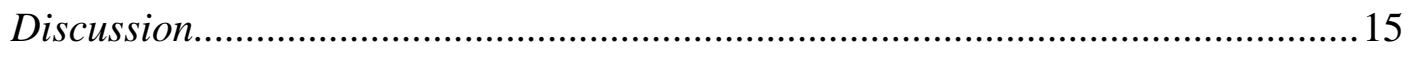

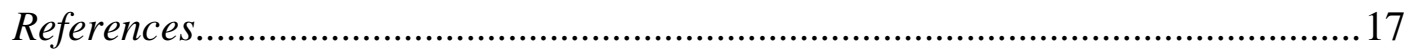

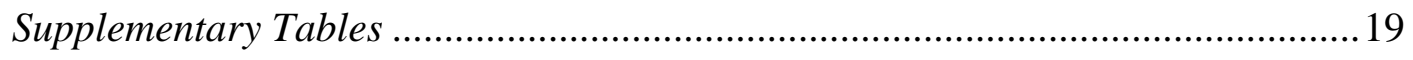

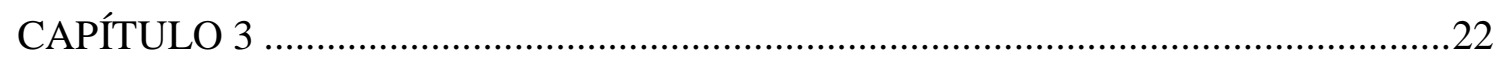

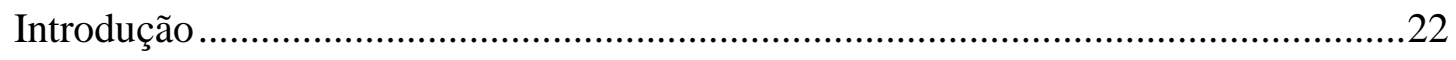

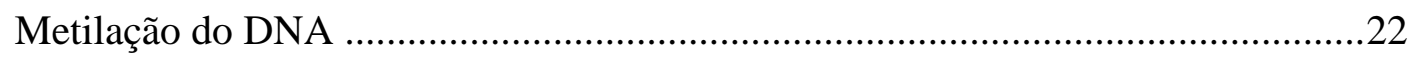

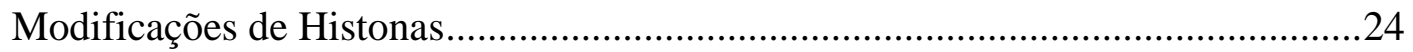


Objetivos

Materiais e Métodos

Amostras

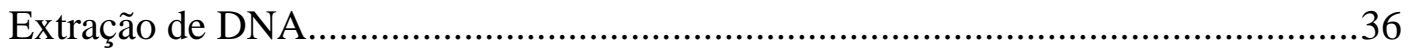

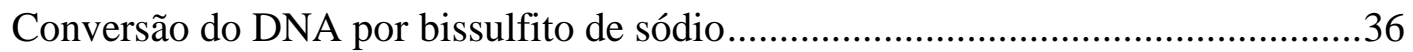

Desenho de iniciadores para Nested PCR e Pirosequenciamento ...........................36

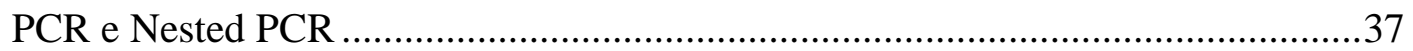

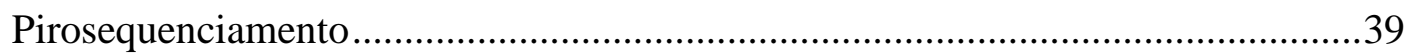

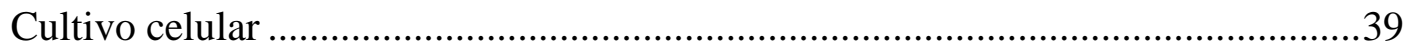

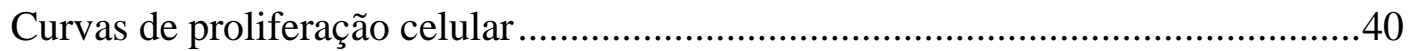

Silenciamento de expressão gênica por RNA de interferência...............................41

Extração de RNA e síntese de cDNA ......................................................................41

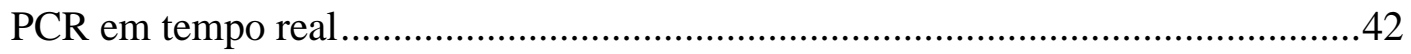

Avaliação de ciclo e morte celular .......................................................................44

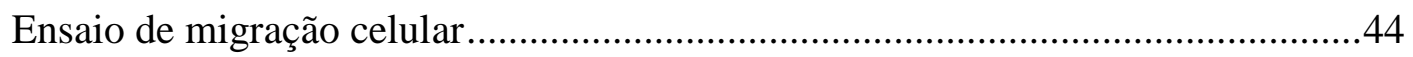

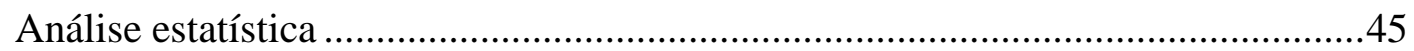

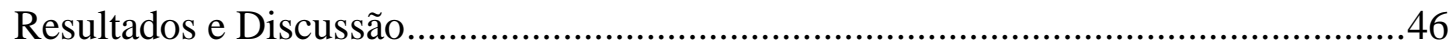

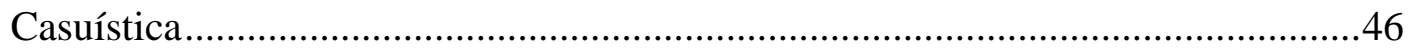

Avaliação da metilação do DNA por pirosequencimento .......................................46

Comparação do perfil de expressão gênica com o padrão de metilação do promotor

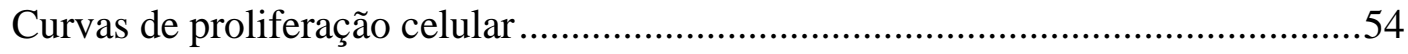

Silenciamento de expressão gênica por RNA de interferência...............................57

Avaliação de ciclo e morte celular ........................................................................59

Ensaio de migração celular..........................................................................6 
RESUMO

\section{CAPÍTULO 4}

Introdução

Materiais e Métodos

Resultados e Discussão

Searching for molecular markers in head and neck squamous cell carninoma (HNSCC) by statistical and bioinformatics analysis of larynx-derived SAGE libraries

Abstract.

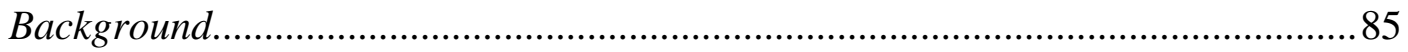

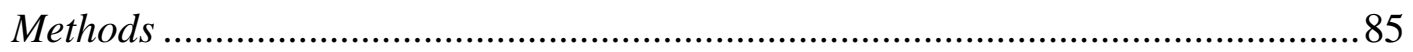

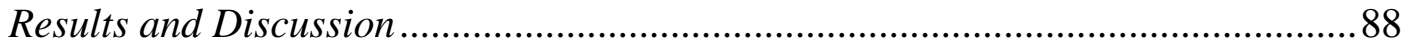

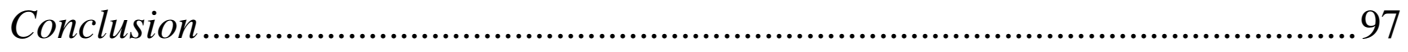

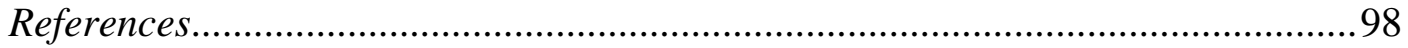

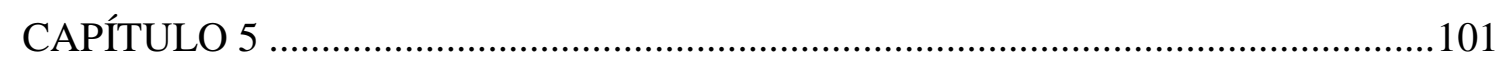

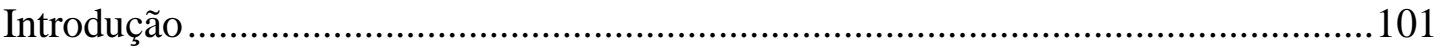

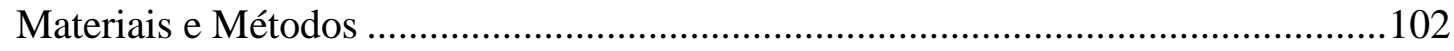

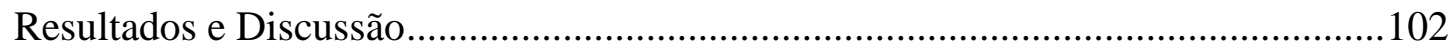




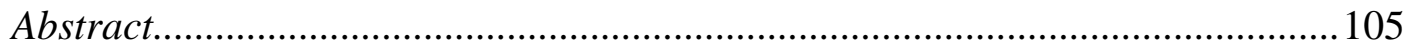

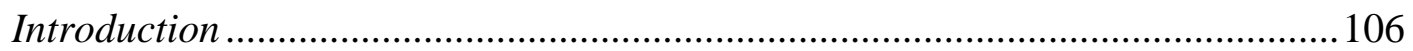

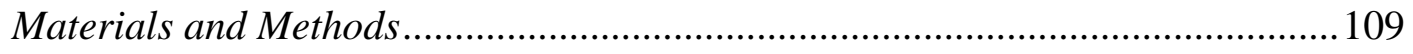

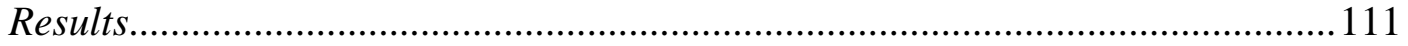

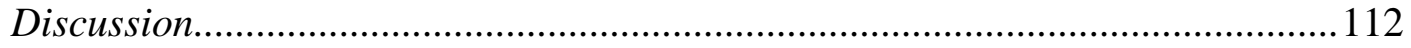

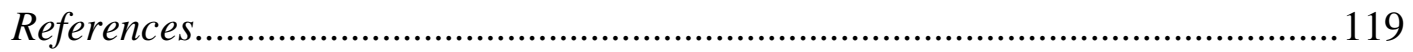




\section{CAPÍTULO 1}

\section{INTRODUÇÃO GERAL}

\section{CARCINOMA EPIDERMÓIDE DE CABEÇA E PESCOÇO}

O carcinoma epidermóide de cabeça e pescoço (CECP) é uma doença heterogênea de origem epitelial que atinge a cavidade oral, a faringe e a laringe (McMahon and Chen 2003), sendo seu principal fator etiológico a exposição crônica ao álcool e ao tabaco (Goldenberg, Lee et al. 2004; Hashibe, Brennan et al. 2009). Embora seja bem conhecido o fato de que há uma elevação da sua freqüência com a idade (Llewellyn, Johnson et al. 2001; Reichart 2001), alguns estudos relatam um aumento de incidência em homens jovens (Patel, Carpenter et al. 2011), mesmo entre aqueles que nunca fumaram ou consumiram álcool. Esses dados indicam que as causas da doença ainda não são bem conhecidas (Llewellyn, Johnson et al. 2001).

No Brasil, foram estimados cerca de 14 mil novos casos em 2010, considerando somente os de cavidade oral (Brasil. Ministério da Saúde 2009), o que representa a maior taxa de incidência desse subgrupo em países com renda média-alta (de Camargo Cancela, Voti et al. 2010). Mundialmente, mais de 500.000 novos casos de carcinomas de CECP são diagnosticados por ano e a incidência varia em diferentes países, provavelmente como resultado de exposição a fatores ambientais distintos (Parkin, Bray et al. 2005). Por exemplo, na França são encontradas taxas mais altas de carcinoma de cavidade oral em comparação aos Estados Unidos e ao Brasil (Moriniere 2006; Jemal, Siegel et al. 2007; Brasil. Ministério da Saúde 2009).

Apesar do uso de tabaco e do consumo de álcool serem os principais fatores de risco em CECP (Goldenberg, Lee et al. 2004; Hashibe, Brennan et al. 2009), outros agentes etiológicos estão relacionados com diferentes etapas da tumorigênese de cabeça e pescoço, como ocupação profissional, características hereditárias, deficiência imunológica e infecção viral (Gallo 1996). Por exemplo, diversos trabalhos indicam o envolvimento do papilomavírus humano (HPV) na etiologia dos CECPs (D'Souza, Kreimer et al. 2007; IARC 2007; Ang, Harris et al. 2010; Jung, Briolat et al. 2010), especialmente nos tumores de orofaringe (Syrjanen 2005; Smeets, Brakenhoff et al. 2009). Alguns polimorfismos em enzimas que metabolizam tabaco e álcool (Hashibe, Boffetta et al. 2006), história familial (Suarez, Rodrigo et al. 2006; Negri, Boffetta et al. 
2009) e baixa ingestão de frutas e vegetais (Freedman, Park et al. 2008; Sapkota, Hsu et al. 2008) também são fatores de risco conhecidos.

Embora tenham ocorrido avanços significativos no tratamento dessa doença, levando à diminuição da morbidade, a taxa de sobrevida em cinco anos permaneceu praticamente inalterada ao longo das últimas décadas. A evolução clínica e a resposta à terapia dos carcinomas epidermóides de cabeça e pescoço são bastante variáveis, mesmo nos casos histologicamente semelhantes (Lingen, Sturgis et al. 2001; Rodrigo, Suarez et al. 2001). Aqueles pacientes com tumores em estágios iniciais geralmente apresentam poucos sintomas, o que costuma atrasar o diagnóstico e reduzir a expectativa de vida. Muitas vezes, o câncer é diagnosticado e tratado apenas quando suas células já invadiram tecidos adjacentes (Wulfkuhle, Paweletz et al. 2003).

Atualmente, as decisões sobre tratamento e prognóstico têm como base a avaliação histopatológica dos tumores e de suas margens cirúrgicas, a presença de metástases em linfonodos e o tamanho do tumor. Contudo, essas variáveis são frequentemente insuficientes para predizer o desfecho clínico. Por exemplo, o status das margens cirúrgicas é utilizado na avaliação do prognóstico, tanto para recorrência como para metástases à distância (Martone, Gillio-Tos et al. 2007). Entretanto, alguns pacientes com margens negativas manifestam lesões múltiplas no mesmo sítio anatômico ou em outros sítios do trato aerodigestivo superior (Poh, Zhang et al. 2006; Roblyer, Kurachi et al. 2009). Estes achados corroboram a hipótese de cancerização de campo proposta por Slaughter e colaboradores (1953) (Slaughter, Southwick et al. 1953), segundo a qual o epitélio ao redor do tumor e de sítios anatômicos vizinhos apresenta alterações que o tornam mais suscetível ao aparecimento de novos tumores. Isto ocorre devido à exposição crônica a insultos carcinogênicos em toda a mucosa do trato aerodigestivo (Lopez-Blanc, Collet et al. 2009).

Essas alterações do tecido são, provavelmente, decorrentes de modificações genéticas e epigenéticas que afetam vias metabólicas importantes e podem ser exploradas tanto para o diagnóstico quanto para o prognóstico de doenças (Leemans, Braakhuis et al. 2011). Califano e colaboradores (1996) sugeriram um modelo de progressão tumoral em CECP envolvendo modificações moleculares durante as várias etapas do desenvolvimento neoplásico (Califano, van der Riet et al. 1996). Nesse modelo, a inativação de genes supressores de tumor e a ativação de proto-oncogenes surgem sequencialmente, desde lesões hiperplásicas benignas até carcinoma invasivo. Alguns estudos moleculares têm continuamente acrescentado novos elementos ao 
modelo de Califano, incluindo mudanças epigenéticas e do microambiente tumoral (Argiris, Karamouzis et al. 2008).

O estabelecimento do padrão de metilação apropriado do DNA é essencial para o desenvolvimento e o funcionamento celular normal. Qualquer anormalidade nesse processo pode levar ao surgimento de várias doenças, incluindo o câncer. A inativação epigenética de genes relacionados com o controle normal do crescimento celular é um evento frequente em câncer é tão importante quanto a inativação por mutação (Esteller and Herman 2002; Park, Claus et al. 2011). A repressão transcricional epigenética tem sido demonstrada em uma ampla variedade de tipos tumorais e ocorre em genes de reparo do DNA, supressores de tumor, reguladores do ciclo celular e em genes envolvidos em processos de invasão e metástase (Garinis, Patrinos et al. 2002; Jaenisch and Bird 2003; Hill, Ricketts et al. 2011; Paluszczak, Misiak et al. 2011).

Nos últimos anos, muitos pesquisadores têm concentrado seus esforços na busca de marcadores moleculares que possam ser utilizados como alvos terapêuticos ou que auxiliem no diagnóstico precoce desse grupo de neoplasias, no seu prognóstico e na identificação de populações de risco (Hunter, Parkinson et al. 2005; Karamouzis, Grandis et al. 2007; Argiris, Karamouzis et al. 2008). Nesse contexto, várias técnicas de análise de expresssão gênica de amplo alcance foram desenvolvidas. Entre essas técnicas, estão os microarranjos de cDNA, a análise seriada de expressão gênica (SAGE) e, mais recentemente, as técnicas de sequenciamento em larga escala, que têm fornecido uma lista crescente de biomarcadores potenciais.

Tais avanços tecnológicos, principalmente no que se refere às novas metodologias de sequenciamento, bem como a novos métodos de isolamento de complexos de DNA, RNA e proteínas, têm possibilitado a melhor compreensão de processos moleculares como splicing alternativo e regulação da transcrição gênica por RNAs não codificantes (Licatalosi, Mele et al. 2008; Sultan, Schulz et al. 2008; Yang, Tschaplinski et al. 2011). Na verdade, os dados têm mostrado que o dogma central da biologia molecular, que coloca os RNAs apenas como intermediários entre as moléculas de DNA e proteína, está caindo por terra.

Vários estudos recentes têm fornecido evidências de que mais de $90 \%$ dos genes humanos sofrem splicing alternativo (Pan, Shai et al. 2008; Wang, Sandberg et al. 2008). Os mecanismos de splicing alternativo e trans-splicing têm revelado a versatilidade do genoma e a importância da unidade de transcrição como fonte de informação genética (Costa, 2010). Tais mecanismos podem ser regulados 
diferencialmente dependendo do tipo celular, do estágio do desenvolvimento ou por diferentes padrões de sinalização (Cooper, Wan et al. 2009) e, quando alterados, representam um fator causal de doenças humanas, incluindo o câncer (Cork, Lennard et al. 2008; Tazi, Bakkour et al. 2009).

Apesar do enorme conhecimento acumulado nos últimos anos, muitos dos eventos genéticos responsáveis pelo desenvolvimento e pela progressão neoplásica permanecem desconhecidos e poucos marcadores moleculares são comumente utilizados na prática médica (Goerner, Seiwert et al. 2010). A busca de novos marcadores moleculares para esse grupo de doenças é, portanto, muito importante, especialmente aqueles relacionados com detecção precoce que podem elevar consideravelmente a taxa de sobrevida dos pacientes. 
OBJETIVOS GERAIS

O objetivo geral do presente trabalho foi investigar biomarcadores de diagnóstico e prognóstico em carcinomas epidermóides de cabeça e pescoço. Os objetivos específicos compreenderam:

1. Identificar diferenças no padrão de metilação do DNA entre linhagens celulares tratadas e não tratadas com droga desmetilantes, bem como em tumores primários de carcinomas epidermóides de cabeça e pescoço.

2. Analisar, pelos métodos de SAGE (Serial Analysis of Gene Expression) e PCR quantitativo em tempo real (qRT-PCR), o perfil de expressão gênica global em amostras de carcinomas epidermóides de cabeça e pescoço.

3. Analisar o perfil de expressão de variantes de splicing alternativo em linhagens celulares submetidas a condições de estresse de temperatura, bem como validar a expressão diferencial de transcritos alternativos em amostras primárias de carcinomas epidermóides de cabeça e pescoço. 


\section{CAPÍTULO 2}

\section{INTRODUÇÃO}

O carcinoma epidermóide de cabeça e pescoço (CECP) é uma doença heterogênea de origem epitelial que atinge a cavidade oral, a faringe e a laringe, sendo seu principal fator etiológico a exposição crônica ao álcool e ao tabaco. Embora tenham ocorrido avanços significativos no tratamento dessa doença, levando à diminuição da morbidade, a taxa de sobrevida em cinco anos permaneceu praticamente inalterada ao longo das últimas décadas. A busca de novos marcadores moleculares para esse grupo de doenças é, portanto, muito importante, especialmente aqueles relacionados com detecção precoce que podem elevar consideravelmente a taxa de sobrevida dos pacientes.

O fenótipo maligno é caracterizado pelo acúmulo de mutações e eventos epigenéticos que modificam a função de proteínas e/ou causam alterações nos padrões transcricionais. A metilação do DNA é uns dos mais importantes mecanismos de silenciamento gênico em tumores e geralmente confere vantagens às células neoplásicas. Sua análise compreende uma ferramenta importante na avaliação de alguns dos mecanismos envolvidos no processo neoplásico.

\section{MATERIAIS E MÉTODOS}

Neste estudo, os métodos de hibridização subtrativa rápida (Rapid Subtractive Hybridization - RaSH), microarranjos de cDNA (cDNA microarrays) e PCR quantitativa em tempo real foram combinados de maneira hierárquica para selecionar genes que são supostamente reativados pelo agente desmetilante 5-aza-2'-deoxicitidina (5-Aza-dC) em linhagens celulares de carcinomas epidermóides de cabeça e pescoço (FaDu, UM-SCC-14A, UM-SCC-17A, UM-SCC-38A). O perfil de metilação do DNA das ilhas CpGs associadas aos promotores dos genes reativados pela droga 5-Aza-dC foram investigados pela técnica de sequenciamento por bissulfito. A análise de metilação diferencial do DNA foi analisada, pelo método de MSP (methyl-specific $P C R$ ), em um painel de 140 amostras de carcinomas primários de cabeça e pescoço. Além disso, a expressão de proteínas de interesse foi avaliada por imunohistoquímica em 75 amostras de CECP, com o objetivo de correlacionar a expressão protéica com o perfil de metilação do DNA e com variáveis clínico-patológicas. 


\section{RESULTADOS E DISCUSSÃO}

No presente trabalho, as técnicas de $\mathrm{RaSH}$ e microarranjos de cDNA foram combinadas com o objetivo de identificar genes com expressão elevada em linhagens celulares de cabeça e pescoço após a utilização de droga desmetilante. Utilizando essa abordagem, foram identificados 78 genes reativados após o tratamento com 5-Aza-dC. Dentre esses, 35 genes que apresentaram expressão elevada em pelo menos duas linhagens celulares e que possuíam ilha $\mathrm{CpG}$ associada aos seus promotores foram selecionados para experimentos de validação por PCR em tempo real. Três deles (CRABP2, MX1 e SLC15A3) exibiram expressão aumentada nas linhagens tratadas com 5-Aza-dC em relação às linhagens não tratadas, com valor superior ao cut off estabelecido, ou seja, um valor de expressão pelo menos três vezes maior que o controle.

O perfil de metilação dos promotores gênicos desses genes foi investigado pela técnica de sequenciamento por bissulfito. As análises de metilação global das ilhas CpG mostraram que os genes $C R A B P 2, M X 1$ e $S L C 15 A 3$ são metilados em pelo menos uma das linhagens celulares não tratadas com o agente desmetilante. O próximo passo foi determinar se os genes seu padrão de metilação em tumores primários de cabeça e pescoço. Utilizando a metodologia de MSP-PCR, os resultados mostraram uma alta freqüência de metilação dos genes $C R A B P 2(58,1 \%)$ e $M X 1$ (46.3\%) em amostras de CECP. As análises imunohistoquímicas revelaram que a ausência da proteína CRABP2 está associada com sobrevida livre de doença. Estes dados sugerem que a expressão de CRABP2 pode ser utilizada como um fator prognóstico para pacientes com CECP. 


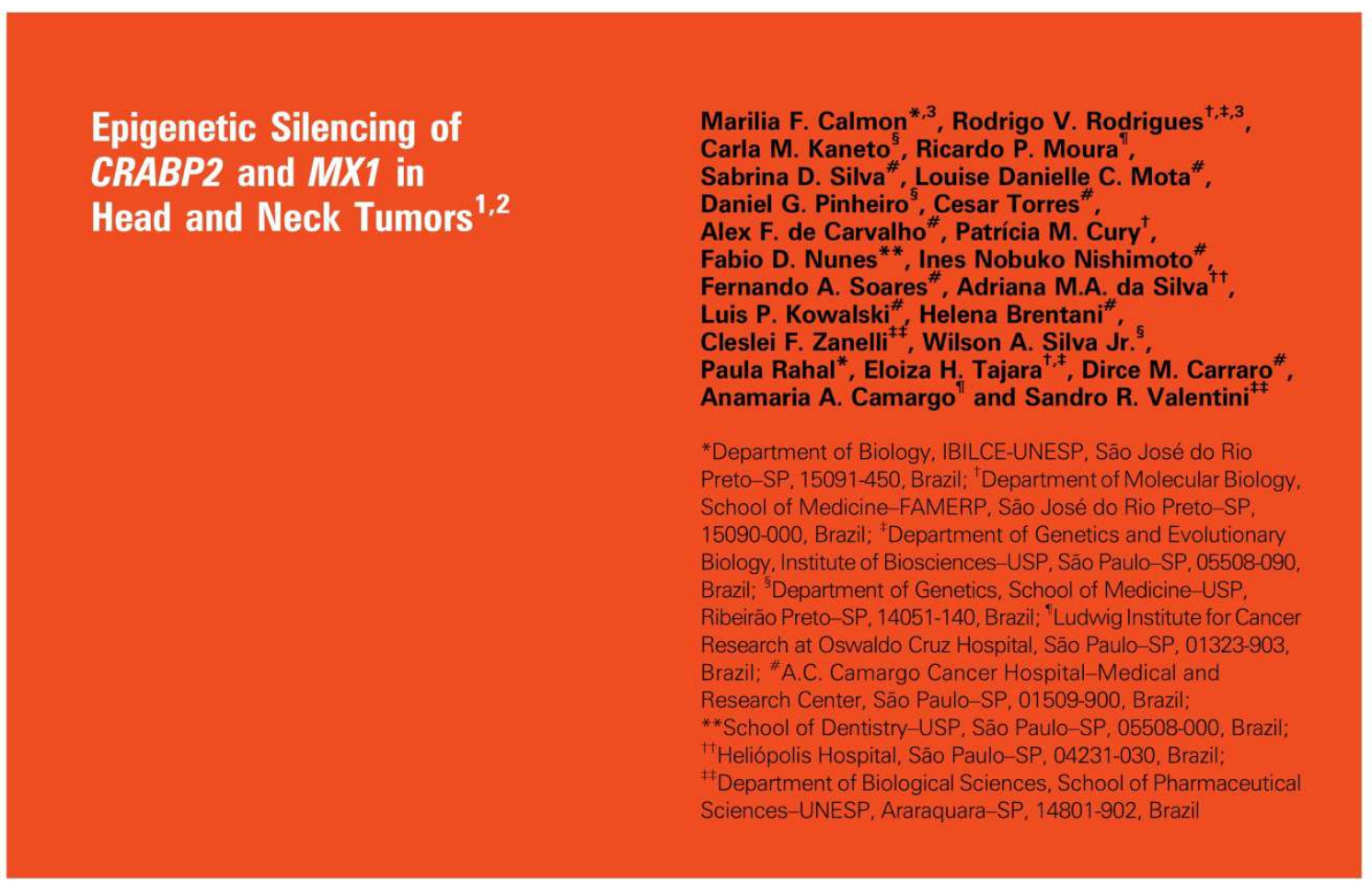

\section{Abstract}

Head and neck squamous cell carcinoma (HNSCC) is a heterogeneous disease affecting the epithelium of the oral cavity, pharynx and larynx. Conditions of most patients are diagnosed at late stages of the disease, and no sensitive and specific predictors of aggressive behavior have been identified yet. Therefore, early detection and prognostic biomarkers are highly desirable for a more rational management of the disease. Hypermethylation of $\mathrm{CpG}$ islands is one of the most important epigenetic mechanisms that leads to gene silencing in tumors and has been extensively used for the identification of biomarkers. In this study, we combined rapid subtractive hybridization and microarray analysis in a hierarchical manner to select genes that are putatively reactivated by the demethylating agent 5-aza-2'-deoxycytidine (5Aza-dC) in HNSCC cell lines (FaDu, UM-SCC-14A, UM-SCC-17A, UM-SCC-38A). This combined analysis identified 78 genes, 35 of which were reactivated in at least 2 cell lines and harbored a CpG island at their $5^{\prime}$ region. Reactivation of 3 of these 35 genes (CRABP2, MX1, and SLC15A3) was confirmed by quantitative real-time polymerase chain reaction (PCR; fold change, $\geq 3$ ). Bisulfite sequencing of their $\mathrm{CpG}$ islands

Abbreviations: 5Aza-dC, 5-aza-2'-deoxycytidine; HNSCC, head and neck squamous cell carcinoma; MSP, methylation-specific polymerase chain reaction; qRT-PCR, quantitative real-time polymerase chain reaction; $\mathrm{RaSH}$, rapid subtractive hybridization; TSS, transcription start site; TMA, tissue microarray

Address all correspondence to: Sandro R. Valentini, Faculdade de Ciências Farmacêuticas - UNESP, Rodovia Araraquara-Jaú, km 01, Araraquara, SP 14801-902, Brazil. E-mail: valentsr@fcfar.unesp.br

${ }^{1}$ This work was supported by grants from FAPESP and CNPq.

${ }^{2}$ This article refers to supplementary materials, which are designated by Tables W1 to W4 and are available online at www.neoplasia.com.

${ }^{3}$ These authors contributed equally.

Received 26 June 2009; Revised 5 August 2009; Accepted 7 August 2009

Copyright () 2009 Neoplasia Press, Inc. All rights reserved 1522-8002/09/\$25.00 DOI $10.1593 /$ neo. 91110 
revealed that they are indeed differentially methylated in the HNSCC cell lines. Using methylation-specific PCR, we detected a higher frequency of CRABP2 $(58.1 \%$ for region 1$)$ and $M X 1(46.3 \%)$ hypermethylation in primary HNSCC when compared with lymphocytes from healthy individuals. Finally, absence of the CRABP2 protein was associated with decreased disease-free survival rates, supporting a potential use of CRABP2 expression as a prognostic biomarker for HNSCC patients.

Neoplasia (2009) 11, 1329-1339

\section{Introduction}

Head and neck squamous cell carcinoma (HNSCC) comprises a heterogeneous disease, which arises from the epithelium of the oral cavity, pharynx, and larynx [1], and is associated with tobacco and alcohol abuse [2]. According to worldwide cancer statistics, approximately 450,000 new oral and laryngeal carcinomas are diagnosed annually, and the incidence varies between countries, probably as a result of environmental risk factors [3]. For example, the incidence rates for oral cancer in males are high in France and comparatively low in the United States and Brazil [4-6].

Although detection of HNSCC in early stages improves the survival rate, most patients present advanced stages of the disease at the time of diagnosis, and no sensitive and specific predictors of aggressive behavior have been identified. Lymph node status is still the most powerful prognostic factor, but the routine histopathologic examination of neck dissection specimens is unable to detect all micrometastases [7]. Therefore, the identification of early detection and prognostic biomarkers is highly desirable for planning an efficient and appropriate treatment procedure.

Evidence for a fundamental role for epigenetic modifications in head and neck cancer cells has been widely reported in the literature, including DNA methylation and histone deacetylation [8,9]. Both promoter hypermethylation of specific genes [10-12] and global hypomethylation are implicated in head and neck tumorigenesis [13,14].

Aberrant DNA methylation, such as regional gains or global loss, is an early event that occurs as a nonrandom signature in almost all tumors [15] and may be used for the identification of biomarkers. Strategies for assessing genome-wide methylation changes include genomic scanning after methylation-specific cleavage of the DNA and two-dimensional electrophoresis, amplification of intermethylated sites by arbitrarily primed polymerase chain reaction (PCR), and microarray gene expression analysis after treatment with DNA demethylating agents such as the DNA methyltransferase inhibitor 5aza-2'-deoxycytidine (5Aza-dC) $[16,17]$. 5Aza-dC is incorporated into genomic DNA during replication, where it acts as an irreversible inhibitor of methyltransferase by forming a covalent complex with methyltransferase active sites. This suicide inhibition depletes methyltransferase activity, resulting in generalized DNA demethylation and release of specific genes from methylation-mediated transcriptional silencing [18].

In the present study, we carried out a genome-wide screening of $5 \mathrm{Aza}-\mathrm{dC}$-reactivated genes in four human squamous cell carcinoma cell lines derived from different topographical sites, using a combination of rapid subtractive hybridization $(\mathrm{RaSH})$ and complementary DNA (cDNA) microarray analysis. This analysis revealed two genes reactivated by $5 \mathrm{Aza}-\mathrm{dC}$ (CRABP2 and $M X 1)$, and they were frequently hypermethylated in primary HNSCCs. Furthermore, the ab- sence of CRABP2 protein was associated with decreased disease-free survival rates, supporting a potential use of CRABP2 expression as a prognostic biomarker for HNSCC.

\section{Materials and Methods}

\section{Tumor Cell Lines and 5Aza-dC Treatment}

Four HNSCC cell lines derived from distinct topographical sites, pharynx $(\mathrm{FaDu})$, floor of the mouth (UM-SCC-14A), supraglottis (UM-SCC-17A), and tonsil (UM-SCC-38A), were used in this study. UM-SCC-14A, UM-SCC-17A, and UM-SCC-38A cell lines were kindly provided by Dr. Thomas E. Carey of the University of Michigan, USA, and FaDu (HTB-43) was purchased from American Type Culture Collection (ATCC, Manassas, VA). Cell lines were routinely cultured as monolayers in minimum essential medium (Eagle) supplemented with $10 \%$ fetal calf serum, $1 \% \mathrm{~L}$-glutamine, and $1 \%$ penicillin/streptomycin, at $37^{\circ} \mathrm{C}$ and $5 \%$ carbon dioxide. Cells were seeded at a density of $10^{6}$ cells $/ 10$-cm dish, cultured for 48 hours, and treated for 4 days with freshly prepared $2.5 \mu \mathrm{M}$ 5Aza-dC (Sigma, St Louis, MO) dissolved in $50 \%$ acetic acid.

\section{Tumor Samples}

For methylation-specific PCR (MSP) analysis, 140 HNSCC samples and 10 lymphocyte samples from normal individuals were used. The samples were obtained from the Tumor Tissue Biobank of the Medical and Research Center - A.C. Camargo Hospital, São Paulo, and from the Head and Neck Genome Project/Gencapo - Brazil after Institutional Ethics Committee approval. Tumor samples were microdissected to enrich for tumor cells. Five-micrometer-thick sections from the frozen tumors were cut onto glass slides, fixed, and stained with hematoxylin and eosin. The hematoxylin and eosinstained section was used as a guide for manual dissection, and only samples with more than $70 \%$ of tumor area were used in this study. All samples were reviewed by two independent pathologists. The main clinicopathological characteristics corresponding to these samples are shown in Table W3. None of the patients received preoperative treatment, and $41.3 \%, 42.0 \%$, and $16.7 \%$ of patients were treated by surgery alone, surgery + radiotherapy, or surgery + radiotherapy + chemotherapy, respectively. The mean follow-up for these patients was approximately 31 months.

For the tissue microarray (TMA) analysis, an independent set of 75 HNSCC samples was used. These samples were obtained from the archives of the Department of Anatomic Pathology, A.C. Camargo Hospital, São Paulo, Brazil, and were reviewed by two independent pathologists. The main clinicopathological characteristics corresponding to these samples are also shown in Table W3. None of the patients received preoperative treatment, and $41.3 \%, 42.0 \%$, and 
$6.7 \%$ of patients were treated by surgery alone, surgery + radiotherapy, or surgery + radiotherapy + chemotherapy, respectively. The average follow-up period was approximately 56 months.

\section{DNA and RNA Extraction}

Genomic DNA from tumor cell lines was purified using a Super Quick Gene DNA Isolation kit (Analytical Genetic Testing Center) following the protocol instructions. Total RNA was isolated using TRIzol Reagent for Molecular Biology (Invitrogen/Life Technologies, Carlsbad, CA). Genomic DNA from tumor samples was purified by standard phenol/chloroform purification. DNA quality was verified by electrophoresis through agarose gel on visualization with ethidium bromide. For microarray experiment, total RNA was further purified using the RNeasy Mini Kit (Qiagen, Valencia, CA). For quantitative real-time PCR (qRT-PCR), $5 \mu \mathrm{g}$ of total RNA was previously treated with the RQ1 RNase-free DNase (Promega, Madison, WI). The RNA integrity after the purification procedure was evaluated using the Agilent 2100-Bioanalyser revealing a minimal RIN value of 7.9.

\section{Rapid Subtractive Hybridization}

$\mathrm{RaSH}$ cDNA libraries were prepared by a modified protocol taken from Jiang et al. [19]. The cDNA were initially digested with $M b o l$ (Gibco, Gaithersburg, MD) at $37^{\circ} \mathrm{C}$ for 1 hour. The fragments were inserted into XhoI-digested pZERO plasmid $(1 \mu \mathrm{g} / \mu \mathrm{l})$ at $16^{\circ} \mathrm{C}$ for 3 hours. The constructs were introduced into the DH10-B competent cells. Two RaSH cDNA libraries were prepared: one using cDNA from the $\mathrm{FaDu}$ cell line treated with $5 \mathrm{Aza}-\mathrm{dC}$ as tester and the mock-treated $\mathrm{FaDu}$ cell line as driver and the other using cDNA from the mocktreated $\mathrm{FaDu}$ cell line as tester and cDNA from the FaDu cell line treated with $5 \mathrm{Aza}-\mathrm{dC}$ as driver.

Bacterial colonies were selected randomly and PCR amplified, using M13 forward and reverse primers. Inserts were sequenced with forward and reverse M13 primers using a DYEnamic ET Dye Terminator Sequencing kit (Amersham Biosciences, Piscataway, NJ) and a MegaBACE 1000 sequencer (Amersham Biosciences). The sequences were analyzed, using an annotation pipeline that consists of four steps: 1) quality checking, phred base-calling, cutoff 0.05 [20,21]; 2) vector trimming and removal of undesirable sequences such as bacterial, mitochondrial, and rRNA sequences; 3) masking of repetitive elements and screening of low-complexity regions by Repeat Masker, using the default settings [22]; and 4) annotation against existing databases, using BLASTN with default parameters. Significant hits were determined by using an $E$-value threshold of $10^{-15}$ for searches against nucleotide sequence databases [23].

\section{cDNA Microarray}

A total of $151 \mathrm{RaSH}$ cDNA clones were amplified by PCR, purified, and spotted onto glass slides (Corning, Corning, NY) with a Flexys Robot (Genomic Solutions, Ann Arbor, MI). A total of 2352 spots, including $151 \mathrm{RaSH}$ cDNA clones, 496 negative controls (pure $\mathrm{H}_{2} \mathrm{O}$ or DMSO), 48 positive controls ( $Q$ gene fragment from phage lambda), and $1657 \mathrm{cDNA}$ fragments derived from other projects were arranged on this customized cDNA platform. Positive hybridization signals from all spots were considered for evaluation of hybridization quality, normalization, and statistical analysis. However, for the purpose of this study, only differences in the expression levels of RaSH cDNA clones were used.
Total RNA extracted from HNSCC cell lines was further purified using the RNeasy Mini Kit (Qiagen) before the RNA amplification procedure. A two-round RNA amplification procedure was carried out as previously described [24]. Amplified RNA was used in a reverse transcription reaction in the presence of random hexamer primer (Invitrogen/Life Technologies), Cy3- or Cy5-labeled dCTP (Amersham Biosciences), and SuperScript II (Invitrogen/Life Technologies). Equal amounts of Cy3- or Cy5-labeled cDNA derived from cell lines treated or not with $5 \mathrm{Aza}-\mathrm{dC}$ were mixed and cohybridized to the customized platform. Dye swap was performed, and hybridizations were carried out in duplicates, resulting in four independent hybridizations for each cell line. Self-self hybridization experiments were performed by pooling the cDNA derived from the four untreated cell lines, labeling them with $\mathrm{Cy} 3$ and $\mathrm{Cy} 5$ independently. Labeled cDNA were then cohybridized to the customized platform. Dye swap was also performed, and hybridizations were carried out in duplicates, resulting in four independent hybridizations for self-self experiments. Arrays were scanned and extracted as previously described [25]. Self-self experiments-based statistical test for low-replication microarray studies was performed to select genes reactivated by $5 \mathrm{Aza}-\mathrm{dC}$ treatment. This strategy has been used to derive intensity-dependent cutoffs to classify a gene as differentially expressed in microarray studies [26]. The cutoff for all comparisons between treated and untreated samples was $99 \%$.

\section{Selection of Genes for Validation by $q R T-P C R$}

Genes that were reactivated by $5 \mathrm{Aza}-\mathrm{dC}$ in at least two of the four cell lines and that possessed a CpG island in their $5^{\prime}$ region were selected for qRT-PCR validation. Genomic sequences corresponding to $5^{\prime}$ regions of reactivated genes were analyzed for the presence of a CPG island using the UCSC Genome Browser (http://genome.ucsc. $\mathrm{edu} /$ ). Criterion for a CpG island was based on those of GardinerGarden and Frommer [27], as a GC content of $50 \%$ or greater, length greater than $200 \mathrm{bp}$, and a ratio greater than 0.6 of the observed number of CG dinucleotides to the expected number for the total number of Gs and Cs in the segment. Repeat Masker (ftp.genome. washington.edu/cgi-bin/Repeat-Masker) was used to determine whether selected $\mathrm{CpG}$ islands contained repetitive elements.

\section{Quantitative Real-time Polymerase Chain Reaction}

qRT-PCR amplification was performed with Power SYBR Green and an ABI 7500 Real-time PCR System (Applied Biosystems, Foster City, CA). The PCR total volume was $20.0 \mu \mathrm{l}$ containing $10.0 \mu \mathrm{l}$ of PCR Power SYBR Green Master Mix, $2.0 \mu \mathrm{l}$ of diluted cDNA, and optimized primer concentrations for each primer pair (Table W4). Conditions were set as an initial polymerase activation step for $2 \mathrm{~min}$ utes at $50^{\circ} \mathrm{C}$ and 10 minutes at $95^{\circ} \mathrm{C}$, followed by 40 cycles of $15 \mathrm{sec}-$ onds at $95^{\circ} \mathrm{C}$ for template denaturation, 1 minute at $60^{\circ} \mathrm{C}$ for extension and fluorescence measurement. Afterward, a dissociation protocol was used for each primer pair to verify the specificity of the qRT-PCR reaction and the absence of primer dimer. All samples were amplified in triplicates and the mean was used for qRT-PCR analysis, and a no-template control was also included. Primers were located in different exons and designed for optimal hybridization kinetics with Primer Express 2.0 (Applied Biosystems). Relative quantification of gene expression was carried out with the mathematical model developed by Pfaffl [28]. All PCR efficiencies were greater than $95 \%$. Nontreated cell lines were used as reference samples, and TUBA1C (TUBAG) was selected as endogenous control gene after GeNorm [29]. 


\section{Bisulfite Sequencing}

Genomic DNA was subjected to sodium bisulfite treatment to modify unmethylated cytosine to uracil, as previously described [30]. Hypermethylation in HNSCC cell lines was determined by the bisulfite sequencing. Bisulfite-treated DNA was amplified by a nested-PCR protocol, using primers designed to amplify $\mathrm{CpG}$-rich regions located at the $5^{\prime}$ regions of $C R A B P 2$ ( -450 to -117 relative to transcription start site [TSS] encompassing $22 \mathrm{CpG}$ dinucleotides), $M X 1$ ( -71 to +845 relative to TSS encompassing $78 \mathrm{CpG}$ dinucleotides), and SLC15A3 ( +351 to +845 relative to TSS encompassing 58 CpG dinucleotides; Figure 2). Primer sequences and PCR amplification conditions are available on request. Amplified products were cloned using the InsTAclone PCR Cloning Kit (Fermentas, Hanover, MD). Five positive clones were sequenced for each cell line using the Big Dye Terminator v3.1 Cycle Sequencing kit and an ABI3130 sequencer, in accordance with manufacturer's instructions (Applied Biosystems). The methylation percentage for each sample was calculated as the proportion of unconverted $\mathrm{CpG}$ dinucleotides among all the CpGs analyzed in all five positive clones.

\section{Methylation-Specific PCR}

Hypermethylation in head and neck tumors was determined by the MSP method as reported by Herman et al. [30], but amplified fragments were analyzed on silver-stained $8 \%$ polyacrylamide gels. Bisulfite-modified DNA was PCR amplified with primers specific for methylated versus unmethylated DNA. Two primer pairs were designed for MSP analysis of the $C R A B P 2$ gene, and a single primer pair was used for the $M X 1$ gene, as indicated in Figure 2. Primer sequences and PCR amplification conditions are available on request.

\section{Tissue Microarray}

To construct the TMA, core biopsies were taken from previously defined areas, with a Tissue Microarrayer (Beecher Instruments, Silver Springs, MD). Tissue cores with a dimension of $1.0 \mathrm{~mm}$ were punched from each specimen and arrayed in duplicate on a recipient paraffin block. Each core was spaced $0.2 \mathrm{~mm}$ apart. After cutting $(3 \mu \mathrm{m})$ on the recipient block and transferring with an adhesive tape to coated slides for subsequent UV cross-linkage (Instrumedics Inc, Hackensack, $\mathrm{NJ}$ ), the slides were dipped in a layer of paraffin to prevent oxidation and kept in a $-20^{\circ} \mathrm{C}$ freezer.

For immunostaining, the sections were deparaffinized and rehydrated in graded ethanol solutions, treated with peroxide to quench endogenous peroxidase $\left(0.3 \% \mathrm{H}_{2} \mathrm{O}_{2}\right.$ for $\left.15 \mathrm{~min}\right)$, and blocked for avidin/biotin (Biotin Blocking System; DAKO, Carpinteria, CA) and for protein (Protein Block Serum-Free; DAKO). Antigenic recovery was performed by wet heating in a pressure cooker. Slides were incubated with anti-CRABP2 (MAB5488, 1:2000; Chemicon, Inc, Temecula, CA). The immunohistochemical reaction was carried out in duplicate at different TMA levels, representing four-fold redundancy for each case. Positive and negative controls were included in all reactions. Positive controls were obtained using normal breast slides incubated with the CRABP2 antibody. CRABP2 binding was assessed by two kinds of negative controls: 1) omitting the primary antibody and incubating slides with phosphate-buffered saline; 2 ) replacing the primary antibody with normal mouse serum.

After scanning each tumor specimen in low power field to choose the most stained area, at least five fields were evaluated under high power. The presence of a clearly visible dark brown precipitation was considered an immunoreaction. Evaluation of CRABP2 included the proportion of reactive cells within the tumors and the staining intensity. The proportion score described the fraction of positively stained tumor cells ( $<10 \%$ of positive cells; $\geq 10 \%$ of tumors cells stained).

The immunostaining intensities were assessed visually by two pathologists using blind analysis by determining the color intensity of stained cells. The samples were classified as negative (no visible reaction or positivity in $<10 \%$ of positive cells) or positive reaction (weak and strongly positive present in $\geq 10 \%$ of tumors cells stained). For statistical analysis, the samples were categorized into two groups: negative and weakly/strongly positive cases.

\section{Statistical Analysis}

For frequency analysis in contingency tables, statistical analyses of associations between variables were performed by the $\chi^{2}$ test or Fisher's exact test (with significance set at $P<.05$ ). The overall survival was defined as the interval between the beginning of treatment and the date of death or the last information for censored observations. The disease-free interval was measured from the date of the treatment to the date when locoregional recurrence or distant metastasis was diagnosed. Overall survival and disease-free survival probabilities were estimated by the Kaplan-Meier method, and the log-rank test was applied to assess the significance of differences among actuarial survival curves. Multivariate analysis was carried out using Cox proportional hazards model (stepwise forward selection). All variables presenting $P<.20$ on the univariate analysis were selected for building a multiple model. For all tests, type I error $(\alpha)$ was established as 0.05 , and results were considered statistically significant when $P<$ .05 . All statistical analyses were performed with the STATA software (Intercooled Stata release 7.0; Stata Corporation, College Station, TX).

\section{Results}

\section{Identification of Genes Reactivated by $5 A z a-d C$}

To identify novel methylation-silenced genes in HNSCC cell lines, we treated the FaDu cell line with the demethylating agent $5 \mathrm{Aza}-\mathrm{dC}$ and used a combination of $\mathrm{RaSH}$ and cDNA microarray analysis to identify genes reactivated on treatment. Initially, two RaSH cDNA libraries were constructed: one using cDNA prepared from the $\mathrm{FaDu}$ cell line treated with $5 \mathrm{Aza}-\mathrm{dC}$ as tester and the mock-treated $\mathrm{FaDu}$ cell line as driver (5Aza-dC tester library) and the other using cDNA prepared from mock-treated $\mathrm{FaDu}$ cell line as tester and cDNA from the $\mathrm{FaDu}$ cell line treated with $5 \mathrm{Aza}-\mathrm{dC}$ as driver (mock tester library; Figure 1). A total of 1773 cDNA clones were sequenced, corresponding to 876 and 897 clones derived from the $5 \mathrm{Aza}$-dC tester and mock tester libraries, respectively. After similarity searches in public databases, we found that these sequences correspond to 415 known genes of which 65 were present in both RaSH libraries. A total of 181 and 169 genes were found exclusively in the 5Aza-dC tester and mock tester libraries, respectively. Of the $181 \mathrm{cDNA}$ clones reactivated by the $5 \mathrm{Aza}-\mathrm{dC}, 151$ were successfully amplified and spotted onto glass slides (Figure 1; Table W1).

Microarray analysis was then carried out with RNA extracted from $\mathrm{FaDu}$ and three additional HNSCC cell lines (UM-SCC-14A, UMSCC-17A, and UM-SCC-38A) derived from distinct topographical sites and treated with 5Aza-dC. Self-self experiments based on a statistical test for low-replication microarray studies were performed to 


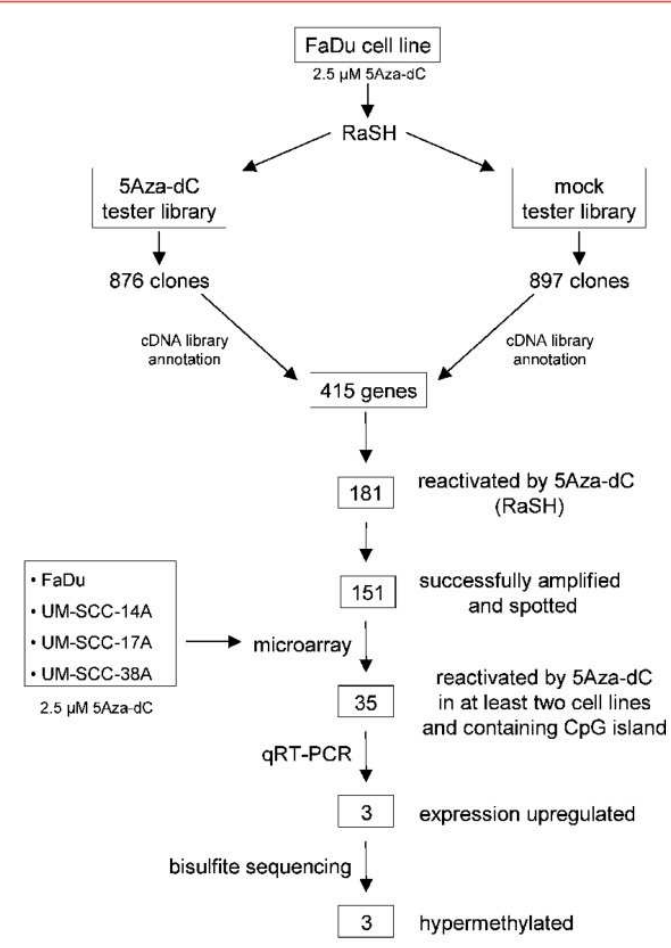

Figure 1. Flowchart for the identification of differentially methylated genes in HNSCC cell lines. FaDu cell line was treated with 5Aza-dC, and purified mRNA was used to construct RaSH cDNA libraries. A set of 151 nonredundant genes was used to prepare an enriched cDNA platform for microarray analysis. A total of 48 genes were reactivated in at least two cell lines. From them, 35 genes harboring a CpG island located at their $5^{\prime}$ region were submitted to qRT-PCR. Up-regulation of gene expression by 5 Aza-dC was confirmed for three genes. Bisulfite sequencing revealed three differentially methylated genes.

identify genes reactivated on treatment. A total of 78 reactivated genes were identified using this combined approach, of which $31,18,47$, and 46 were identified in the FaDu, UM-SCC-14A, UM-SCC-17A, and UM-SCC-38A cell lines, respectively. A total of 48 genes were reactivated in at least two cell lines and used for further investigation. We reasoned that commonly reactivated genes, inactivated in at least two HNSCC, were more likely to represent genes frequently inactivated in tumors.

\section{Validation Analysis by qRT-PCR of Genes Reactivated by} $5 A z a-d C$ in HNSCC Cell Lines

Of the 48 genes selected by the microarray analysis, 35 harbored a bona fide $\mathrm{CpG}$ island in the $5^{\prime}$ region and were further selected for qRT-PCR quantification of gene expression in the same cell lines used in the microarray analysis (Table W2). Three genes (CRABP2, $M X 1$, and $S L C 15 A 3$ ) were confirmed to be reactivated at least threefold in at least one of the cell lines after $5 \mathrm{Aza}-\mathrm{dC}$ treatment. All these genes were upregulated in the $\mathrm{FaDu}$ cell line. In addition, the CRABP2 and $M X 1$ genes were also upregulated in the UM-SCC-14A and UMSCC-38A cell lines, respectively (Table 1 ).

\section{DNA Methylation Analysis in HNSCC Cell Lines}

The methylation status of the $\mathrm{CpG}$ island at the $5^{\prime}$ region site of the CRABP2, MX1, and SLC15A3 genes was then investigated by bisulfite sequencing in HNSCC cell lines that showed induction of gene expression after $5 \mathrm{Aza}-\mathrm{dC}$ treatment.

A significant reduction in the global methylation level (from $40.00 \%$ to $5.50 \%$ ) of the $5^{\prime}$ region of CRABP2 was observed in the $\mathrm{FaDu}$ cell line after treatment with the demethylating agent, which is in agreement with the 4.6-fold increase in the CRABP2 messenger RNA (mRNA) level observed in this cell line treated with 5 Aza-dC. Corroborating this result (Figure 2), reduction in the methylation levels was observed for almost all $\mathrm{CpG}$ dinucleotides analyzed.

A less pronounced reduction in the DNA methylation level of the $M X 15^{\prime}$ region was observed in the $\mathrm{FaDu}$ (from $27.70 \%$ to $12.70 \%$ ) and UM-SCC-14A (from $7.80 \%$ to $1.02 \%$ ) cell lines (Figure 2). The reduction was limited to dinucleotides 39 to 56 located within the first exon of the $M X I$ gene. Reduction in the methylation levels of these specific dinucleotides was directly correlated with induction of gene expression on treatment observed in these cell lines, as measured by qRTPCR (22.4-fold for FaDu and 4.5-fold for UM-SCC-14A), suggesting that these dinucleotides play a critical role in transcription regulation.

In the case of SLC15A3 gene, an increase of 7.3- and 3.0-fold in its expression level was observed in the $\mathrm{FaDu}$ and UM-SCC-38A cell lines, respectively. However, a significant reduction (from $96.6 \%$ to $5.5 \%$ ) in the DNA methylation level of the $S L C 15 A 35^{\prime}$ region was exclusively observed in the UM-SCC-38A cell line. These results suggest that other epigenetic mechanisms, such as histone modification, may also play a critical role in regulating the expression of the SLC15A3 gene.

\section{DNA Methylation Analysis in Primary HNSCC}

We next sought to determine whether CRABP2 and $M X 1$ hypermethylation, identified in the preceding experiments using cell lines, was also present in primary HNSCC. The methylation status of $S L C 15 A 3$ was not further investigated in primary tumors because

Table 1. Validation of Gene Expression Reactivation by Microarray Analysis and qRT-PCR in 5Aza-dC-Treared HNSCC Cell Lines.

\begin{tabular}{|c|c|c|c|c|c|c|c|c|}
\hline \multirow[t]{2}{*}{ Official Symbol } & \multicolumn{4}{|c|}{ Microarray } & \multicolumn{4}{|c|}{ qRT-PCR (Fold Change) } \\
\hline & $\mathrm{FaDu}$ & UM-SCC-14A & UM-SCC-17A & UM-SCC-38A & $\mathrm{FaDu}$ & UM-SCC-14A & UM-SCC-17A & UM-SCC-38A \\
\hline CRABP2 & Up & Up & Up & - & 4.6 & 1.9 & 1.7 & ND \\
\hline$M X 1$ & Up & Up & - & Up & 22.4 & 4.5 & ND & 0.2 \\
\hline SLCI5A3 & $\mathrm{Up}_{\mathrm{p}}$ & $U_{p}$ & Up & Up & 7.3 & 2.2 & 1.0 & 3.0 \\
\hline
\end{tabular}

$N D$ indicates not determined; $U p$, upregulated. 
A

\section{CRABP2}

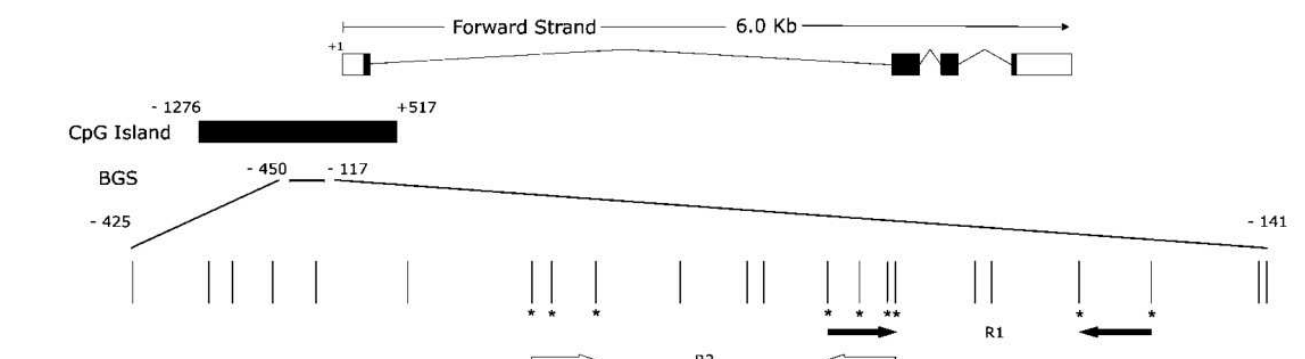

$\begin{array}{rrrrrr} & & & \\ 8 & 8 & 8 & 8 & 8 & 8 \\ 18 & 8 & 8 & 8 & 8 & 8 \\ \mathbf{1} & 8 & 8 & 8 & 8 & 8\end{array}$

B
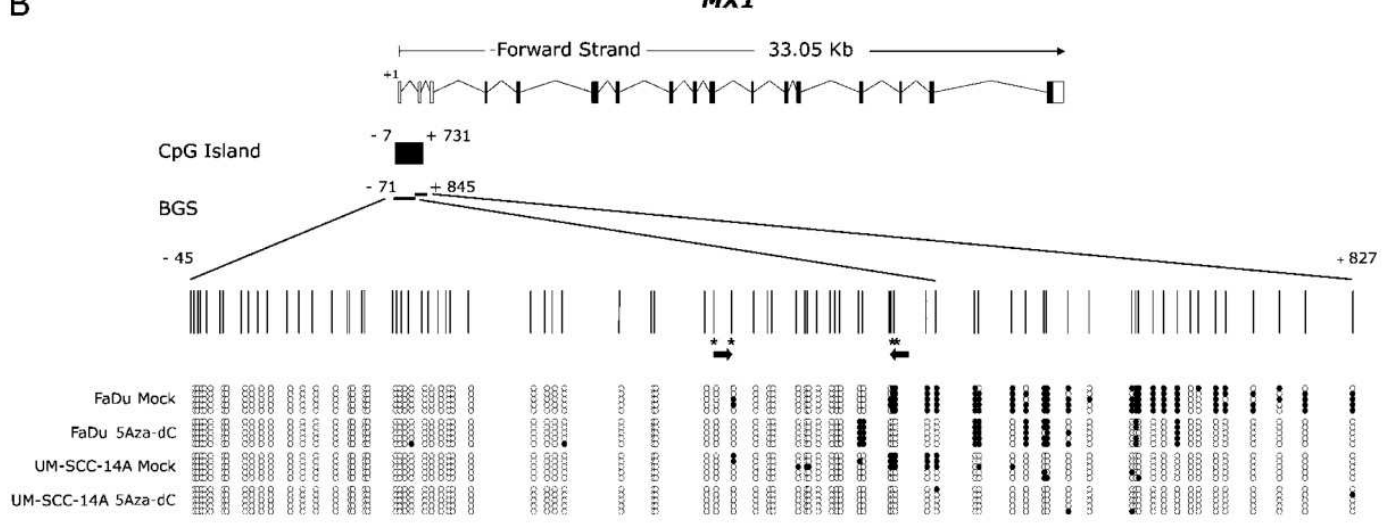

C

SLC15A3

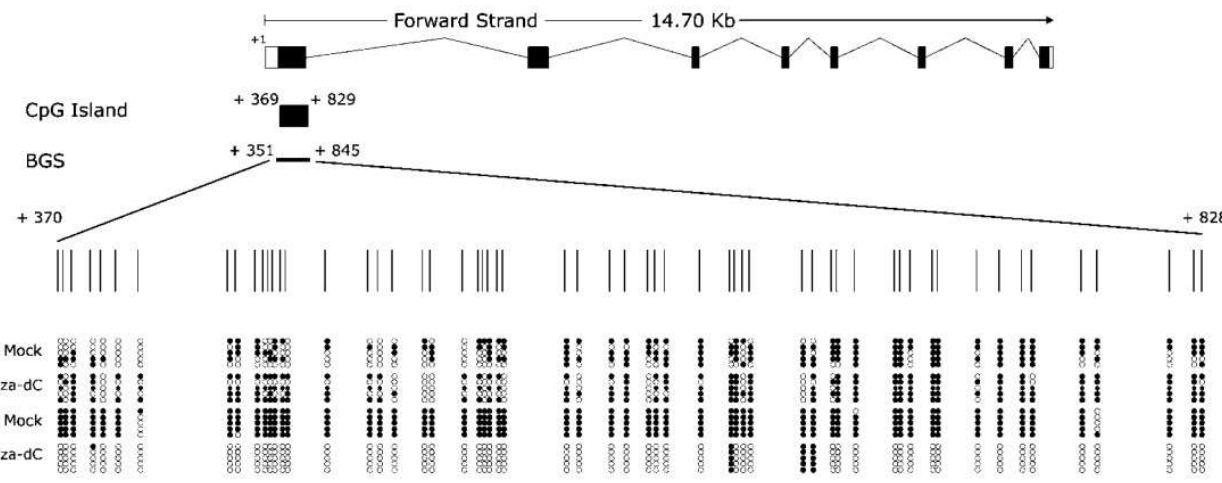

Figure 2. A representative result of bisulfite sequencing. Each panel represents a schematic representation of the genome structure of each gene including their $5^{\prime} \mathrm{CpG}$ islands. Exons and untranslated regions are represented by filled or open boxes, respectively. The transcription initiation site is represented by +1 . Expanded view shows the position of $\mathrm{CpG}$ islands and the region analyzed by bisulfite sequencing. Vertical marks represent individual $\mathrm{CpG}$ dinucleotides and their spacing accurately reflects the $\mathrm{CpG}$ density of the region. MSP primers are represented by horizontal arrows in the panels. Primer sets $\mathrm{M}$ and $U$ were designed for the same CpG dinucleotide (indicated by an asterisk). Methylation profiles of the treated (5Aza-dC) and untreated (mock) cell lines are indicated in the lower part of the panels. Each row represents one sequenced clone, and open and filled circles represent unmethylated and methylated CpG dinucleotides, respectively. (A) Bisulfite sequencing of $C R A B P 2$ in the FaDu cell line. (B) Bisulfite sequencing of $M X 1$ in the FaDu and UM-SCC-14A cell lines. (C) Bisulfite sequencing of SLC15A3 in the FaDu and UM-SCC-38A cell lines. 


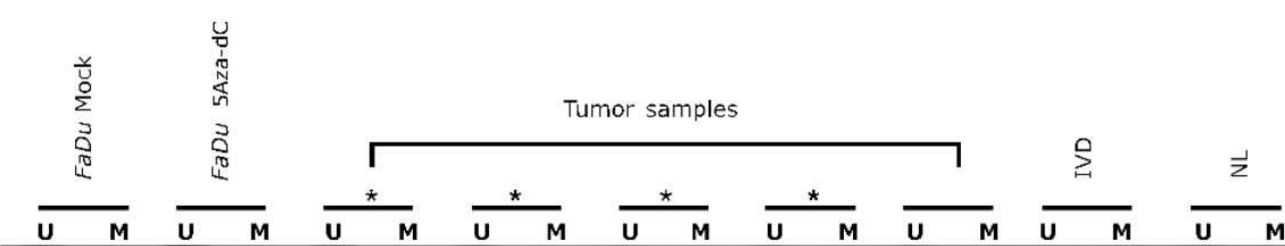

A
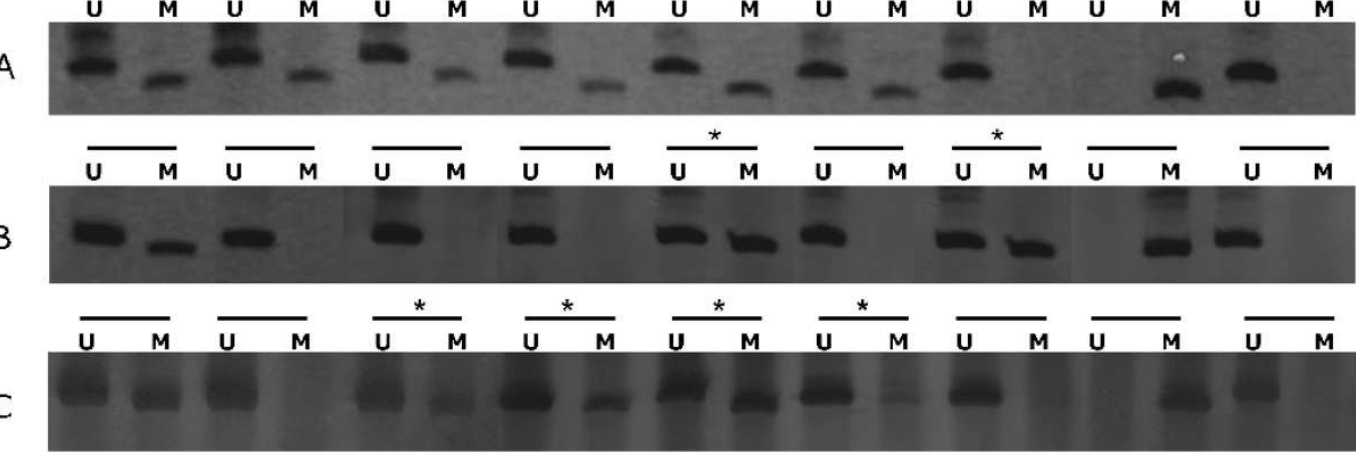

Figure 3. MSP analysis of $C R A B P 2$ and $M X 1$ genes. Representative results of MSP analysis of $C R A B P 2$ and $M X 1$ genes in the FaDu cell line and five different HNSCC samples. Methylated tumors are indicated with asterisks. The lanes indicated by $\mathrm{M}$ and $\mathrm{U}$ correspond to the products amplified by MSP primer sets specific for methylated and unmethylated DNA, respectively. In vitro methylated DNA (IVD) and normal human peripheral lymphocytes (NL) were used as positive and negative methylation controls, respectively. (A) MSP of CRABP2 R1. (B) MSP of CRABP2 R2. (C) MSP of MX1.

we were unable to detect a direct correlation between DNA methylation level and gene expression. MSP analysis of CRABP2 and $M X 1$ was carried out in 140 HNSCC samples and 10 lymphocyte samples from normal individuals. The main clinicopathological characteristics of the HNSCC patients are shown in supplementary data (Table W3), and representative MSP results are shown in Figure 3. MSP primers were designed to target the most frequently methylated CpG dinucleotides and those with a direct correlation with mRNA expression as revealed by bisulfite sequencing of the tumor cell lines. Two primer pairs were designed for MSP analysis of the CRABP2 (one pair for region $1-\mathrm{R} 1$ and one pair for region $2-\mathrm{R} 2$ ) and a single primer pair was used for the $M X I$ gene, as indicated in Figure 2.

CRABP2 hypermethylation was detected in $56.4 \%(79 / 140)$ of the samples when primers for R1 were used and in $10.0 \%$ (14/ 140 ) of the samples when reactions were carried out with R2 primers. For 13 patients $(9.3 \%)$, hypermethylation was detected with both primer pairs. No CRABP2 hypermethylation was detected in normal lymphocytes for both primer pairs. We then investigated the association between CRABP2 hypermethylation and well-established clinicopathological parameters used for HNSCC. As shown in Table 2,

Table 2. Relationship between Methylation Analyses of $C R A B P 2$ and $M X I$ and Clinicopathological Variables in HNSCC Parients.

\begin{tabular}{|c|c|c|c|c|c|c|c|c|c|c|}
\hline \multirow[t]{2}{*}{ Variables } & \multirow[t]{2}{*}{ Category } & \multicolumn{3}{|c|}{$C R A B P 2 \mathrm{R} 1,{ }^{*} n(\%)$} & \multicolumn{3}{|c|}{$C R A B P 2 \mathrm{R} 2,{ }^{*} n(\%)$} & \multicolumn{3}{|l|}{$M X I, * n(\%)$} \\
\hline & & Unmethylated & Methylated & $P$ & Unmethylated & Merhylated & $P$ & Unmethylated & Methylated & $P$ \\
\hline \multirow[t]{2}{*}{ Age } & $\leq 53$ & $26(44.07)$ & $23(29.49)$ & .078 & $47(38.52)$ & $2(14.29)$ & .074 & $29(40.85)$ & $20(30.30)$ & .198 \\
\hline & $>53$ & $33(55.93)$ & $55(70.51)$ & & $75(61.48)$ & $12(85.71)$ & & $42(59.15)$ & $46(69.70)$ & \\
\hline \multirow[t]{3}{*}{ Tumor site } & Oral cavity & $29(49.16)$ & 34 (43.04) & $.010^{+}$ & $58(47.15)$ & $4(28.57)$ & .097 & $39(54.17)$ & $24(36.36)$ & .095 \\
\hline & Larynx & $15(25.42)$ & $8(10.13)$ & & $22(17.89)$ & $1(7.14)$ & & $9(12.50)$ & $14(21.21)$ & \\
\hline & Hypopharynx & $15(25.42)$ & $37(46.84)$ & & $43(34.96)$ & $9(64.29)$ & & $24(33.33)$ & $28(42.43)$ & \\
\hline \multirow[t]{2}{*}{ Tumor size } & $\mathrm{T} 1+\mathrm{T} 2$ & $14(25.00)$ & $20(26.32)$ & .864 & $30(25.42)$ & $4(30.77)$ & .676 & $13(18.31)$ & $21(34.43)$ & $.035^{\dagger}$ \\
\hline & $\mathrm{T} 3+\mathrm{T} 4$ & $42(75.00)$ & $56(73.68)$ & & $88(74.58)$ & $9(69.23)$ & & $58(81.69)$ & $40(65.57)$ & \\
\hline \multirow[t]{2}{*}{ Lymph nodes } & No & $10(17.54)$ & $16(21.33)$ & .588 & $21(17.80)$ & $5(38.46)$ & .076 & $15(21.13)$ & $11(18.03)$ & .656 \\
\hline & $\mathrm{N}_{+}$ & $47(82.46)$ & $59(78.67)$ & & $97(82.20)$ & $8(61.54)$ & & $56(78.87)$ & $50(81.97)$ & \\
\hline \multirow[t]{3}{*}{ Grade } & 1 & $11(19.64)$ & $25(34.25)$ & .184 & $34(29.57)$ & $2(15.38)$ & .595 & $21(31.34)$ & $15(24.19)$ & .563 \\
\hline & 2 & $36(64.29)$ & $39(53.42)$ & & $65(56.52)$ & $9(69.23)$ & & $36(53.73)$ & $39(62.90)$ & \\
\hline & 3 & $9(16.07)$ & $9(12.33)$ & & $16(13.91)$ & $2(15.38)$ & & $10(14.93)$ & $8(12.90)$ & \\
\hline \multirow[t]{2}{*}{ Vascular invasion } & No & $35(60.34)$ & $51(68.92)$ & .305 & $76(64.41)$ & $10(76.92)$ & .367 & $40(57.14)$ & $45(72.58)$ & .055 \\
\hline & Yes & $23(39.66)$ & $23(31.08)$ & & $42(35.59)$ & $3(23.08)$ & & $30(42.86)$ & $17(27.42)$ & \\
\hline \multirow[t]{2}{*}{ Lymphatic permeation } & No & $49(84.48)$ & $64(87.67)$ & .599 & $100(84.75)$ & $12(100)$ & .145 & $57(82.61)$ & $56(90.32)$ & .200 \\
\hline & Yes & $9(15.52)$ & $9(12.33)$ & & $18(15.25)$ & 0 & & $12(17.39)$ & $6(9.68)$ & \\
\hline \multirow[t]{2}{*}{ Perineural infiltration } & No & $27(46.55)$ & $42(57.53)$ & .211 & $60(51.28)$ & $9(69.23)$ & .219 & $38(55.07)$ & $31(50.00)$ & .562 \\
\hline & Yes & $31(53.45)$ & $31(42.47)$ & & $57(48.72)$ & $4(30.77)$ & & $31(44.93)$ & $31(50.00)$ & \\
\hline
\end{tabular}

$R l$ indicates region $1 ; R 2$, region 2 .

"Percentages considering cases with complete information.

${ }^{4}$ Statistically significant. 
a statistically significant association was found between tumor site and CRABP2 hypermethylation in region $1(P=.010)$. It was observed that hypopharynx tumors showed a higher frequency of methylation (37/52 or $71.2 \%$ ) when compared with the other tumor sites. KaplanMeier analysis was then used to estimate the relationship between the methylation status of the $C R A B P 2$ gene with overall and disease-free survival. No difference in terms of overall or disease-free survival was observed between patients with or without $C R A B P 2$ hypermethylation in their primary tumors.

Hypermethylation in the $5^{\prime}$ region of the $M X 1$ gene was detected in $45.0 \%(63 / 140)$ of the HNSCC patients. Similar to what was observed for $C R A B P 2$, no $M X 1$ hypermethylation was detected in normal lymphocytes. A statistically significant association was observed between $M X 1$ hypermethylation and tumor size $(P=.035)$ and a marginal association with vascular invasion $(P=.055$; Table 2$)$. However, as for $C R A B P 2$, no difference in terms of overall or disease-free survival was observed between patients that did or did not show $M X 1$ hypermethylation in primary tumors.

\section{CRABP2 Protein Expression in HNSCC Primary Tumors}

CRABP2 protein expression was then analyzed in HNSCC tumors by immunohistochemistry using a TMA containing 75 HNSCC samples. As shown in Figure $4 A$, CRABP2 protein immunostaining was detected in the morphologically normal epithelium samples used as controls, more intense staining being detected in the suprabasal (postmitotic) epithelial cells. Among the 75 HNSCC samples, 8 cases (11\%) were negative, 37 cases (51\%) were weakly positive, and 28 cases (38\%) were strongly positive (Figure $4, B-D$ ). Two samples did not con- tain representative sections of the tumor tissue and were not considered in the analysis. For all further analysis, weakly and strongly positive tumors were treated as a single group with positive CRABP2 protein expression.

We then analyzed the possible association between the expression of CRABP2 protein and clinicopathological variables. As shown in Table 3 , a statistically significant association was observed between CRABP2 staining and increased tumor size $(\mathrm{T} 3+\mathrm{T} 4 ; P=.029)$ and absence of lymphatic permeation $(P=.014)$. Univariate analysis was used to estimate the association between CRABP2 protein expression and overall or disease-free survival. No difference in terms of overall survival was observed with CRABP2 protein expression. Interestingly, our data show that an absence of CRABP2 expression was associated with a worse disease outcome because patients whose tumors were negative for $C R A B P 2$ expression had a higher risk of locoregional recurrence or distant metastasis than patients with CRABP2-positive tumors (log-rank test, $P=.0531$; Figure 5 ). In the Cox regression univariate model, CRABP2 protein expression showed a protective hazard ratio of 0.40 (95\% confidence interval, 0.1-1.0). However, in the multivariate analysis, CRABP2 protein expression was not shown to be an independent prognostic factor for disease-free survival owing to the small number of CRABP2-negative tumors or to the presence of confounding variables such as tumor size and site and the occurrence of lymphatic permeation.

\section{Discussion}

Treatment with $5 \mathrm{Aza}-\mathrm{dC}$ in combination with histone deacetylase inhibitors has been widely used to reactivate epigenetically silenced
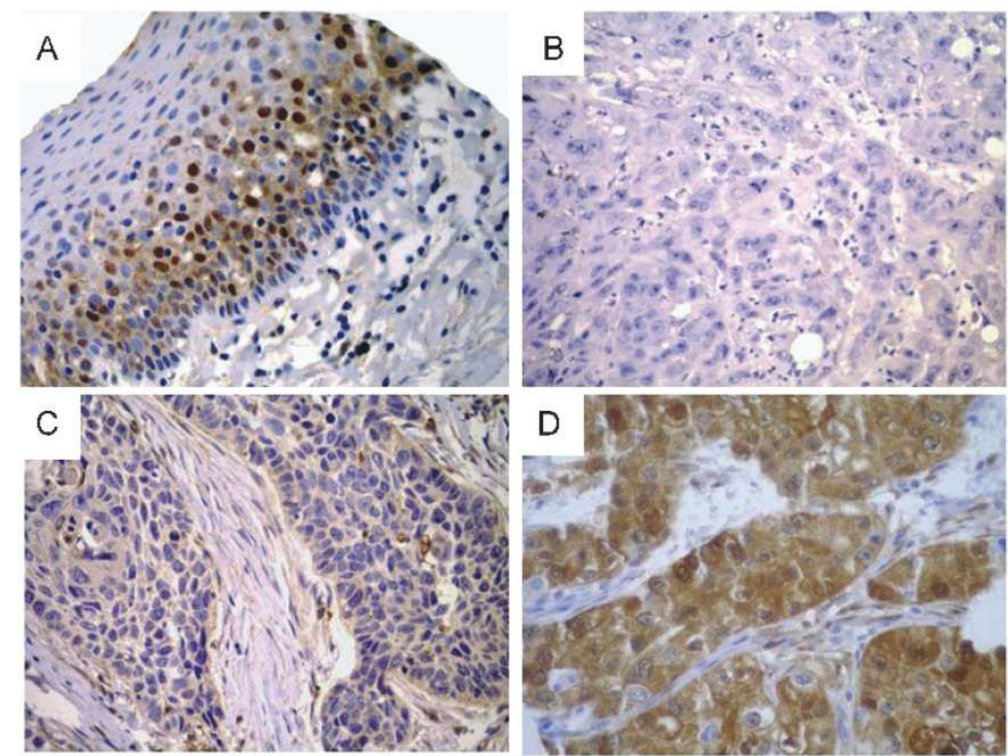

Figure 4. CRABP2 protein immunostaining patterns. Representative immunostainings of (A) morphologically normal epithelium and (B-D) HNSCC samples for CRABP2. Chromogenic detection (brown precipitate) counterstained with hematoxylin. Original magnifications: A, $\times 200$ (A); B-D, $\times 400$. Staining was scored as negative (B), weakly positive (C), or strongly positive (D). 
Table 3. Relationship between CRABP2 Protein Expression and Clinicoparhological Variables in HNSCC Patients.

\begin{tabular}{|c|c|c|c|c|}
\hline \multirow[t]{2}{*}{ Variables } & \multirow[t]{2}{*}{ Caregory } & \multicolumn{2}{|c|}{ CRABP $2,{ }^{*} n(\%)$} & \multirow[t]{2}{*}{$P$} \\
\hline & & Negative & Positive & \\
\hline \multirow[t]{2}{*}{ Age } & $\leq 53$ & $1(50.00)$ & $13(55.38)$ & \multirow[t]{2}{*}{$>.999$} \\
\hline & $>53$ & $7(50.00)$ & $52(44.62)$ & \\
\hline \multirow[t]{3}{*}{ Tumor site } & Oral cavity & $3(37.50)$ & $20(30.77)$ & \multirow[t]{3}{*}{ NA } \\
\hline & Larynx & $4(50.00)$ & $26(40.00)$ & \\
\hline & Hypopharynx & $1(12.50)$ & $19(29.23)$ & \\
\hline \multirow[t]{2}{*}{ Tumor size } & $\mathrm{T} 1+\mathrm{T} 2$ & $5(71.43)$ & $17(29.82)$ & \multirow[t]{2}{*}{$.029^{\dagger}$} \\
\hline & $\mathrm{T} 3+\mathrm{T} 4$ & $2(28.57)$ & $40(70.18)$ & \\
\hline \multirow[t]{2}{*}{ Lymph nodes } & No & $5(62.50)$ & $56(91.80)$ & \multirow[t]{2}{*}{.075} \\
\hline & $\mathrm{N}_{+}$ & $3(37.50)$ & $5(8.20)$ & \\
\hline \multirow[t]{3}{*}{ Histologic grade } & 1 & $3(37.5)$ & $22(33.85)$ & \multirow[t]{3}{*}{ NA } \\
\hline & 2 & $5(62.5)$ & $36(55.38)$ & \\
\hline & 3 & 0 & 7 (10.77) & \\
\hline \multirow[t]{2}{*}{ Vascular invasion } & No & $6(75.00)$ & $50(80.65)$ & \multirow[t]{2}{*}{.707} \\
\hline & Yes & $2(25.00)$ & $12(19.35)$ & \\
\hline \multirow[t]{2}{*}{ Lymphatic permeation } & No & $2(25.00)$ & $43(69.35)$ & \multirow[t]{2}{*}{$.014^{\dagger}$} \\
\hline & Yes & $6(75.00)$ & $19(30,65)$ & \\
\hline \multirow[t]{2}{*}{ Perineural infiltration } & No & $6(75.00)$ & $34(54.84)$ & \multirow[t]{2}{*}{.278} \\
\hline & Yes & $2(25.00)$ & $28(45.16)$ & \\
\hline
\end{tabular}

$N A$ indicates not applied.

*Percentages considering cases with complete information.

"Percentages considering
${ }^{\dagger}$ Statistically significant.

genes in cell lines from several types of tumor [31-35]. Although this approach can lead to secondary effects on gene expression, it seems to be very efficient compared with alternative strategies in which CpG island arrays are hybridized with genomic DNA digested with methylation-sensitive restriction enzyme $[15,36]$ because it relies directly on the reactivation of gene expression rather than on the presence of a CpG island.

In the present study, we have used $5 \mathrm{Aza}-\mathrm{dC}$ to identify genes putatively silenced by DNA hypermethylation. Histone deacetylase inhibitors were not used because previous studies using similar strategies have demonstrated that most genes are reactivated by high-dose $5 \mathrm{Aza}-\mathrm{dC}$ treatment, and only a small subset of genes is induced by the synergistic treatment with demethylating agents and deacetylase inhibitors $[32,33]$.

To evaluate changes in gene expression induced by $5 \mathrm{Aza}-\mathrm{dC}$ treatment, we used a combination of $\mathrm{RaSH}$ and cDNA microarray analysis. The RaSH methodology has been extensively used in the identification of differentially expressed genes, and in our study, it was used in an attempt to enrich the cDNA microarray for $5 \mathrm{Aza}-\mathrm{dC}$ reactivated genes and not limit our analysis to a set of predefined genes represented in commercial arrays. Two RaSH cDNA libraries were constructed: 5Aza$\mathrm{dC}$ tester and mock tester. The mock tester library was constructed in an attempt to identify false-positive genes that were found in both cDNA libraries and as a control of the subtraction efficiency. We identified 415 known genes of which only 65 were present in both RaSH libraries, indicating a high subtraction efficiency. In addition, we were able to identify 181 genes putatively induced by $5 \mathrm{Aza}-\mathrm{dC}$ in the $\mathrm{FaDu}$ cell line, and 151 of these genes were spotted on the microarray platform and analyzed for gene reactivation in three additional HNSCC cell lines. Using this combined approach, we identified 78 genes induced on treatment and selected 35 genes, induced in at least two of the cell lines and which contained a CpG island at the $5^{\prime}$ region for technical validation by qRT-PCR. Gene expression increased at least three-fold on $5 \mathrm{Aza}-\mathrm{dC}$ treatment in 3 of the 35 genes analyzed (CRABP2, MX1, and SLC15A3) and 2 of them (CRABP2 and MXI) were indeed hypermethylated in the cell lines used in this study. MSP was then used to examine the DNA methylation status of CRABP2 and $M X 1$ in a set of 140 primary HNSCCs. MSP primers were designed to target the most frequently methylated $\mathrm{CPG}$ dinucleotides and those with a direct correlation with mRNA expression as revealed by bisulfite sequencing of the tumor cell lines. Because the $\mathrm{CpG}$-rich region located at the $5^{\prime}$ region of $C R A B P 2$ contains 22 CpG dinucleotides, two primer pairs (R1 and R2) were designed for MSP analysis of $C R A B P 2$ in primary tumors. Unfortunately, owing to the higher GC content of the $5^{\prime}$ region of the $M X 1$ gene, we were able to design a single primer pair for MSP analysis of MX1. CRABP2 hypermethylation was specifically detected in $56.4 \%$ and in $10.0 \%$ of the tumors when reactions were carried out with R1 and R2 primers, respectively. The difference in the methylation frequencies observed for different primer pairs is expected because MSP primers were placed at different CpG dinucleotides. $M X 1$ hypermethylation was specifically detected in $45.0 \%$ of primary HNSCCs. Taken together, these results suggest that $C R A B P 2$ and $M X 1$ mRNA expression is regulated by DNA methylation and that $C R A B P 2$ and $M X 1$ hypermethylation is frequent among HNSCCs. Interestingly, CRABP2 (R1) or $M X 1$ hypermethylation showed statistically significant association with tumor site or tumor size, respectively. In the case of $C R A B P 2$, hypopharynx tumors showed a higher frequency of promoter methylation when compared with the other tumor sites.

The human $M X 1$ (myxovirus resistance 1) gene, also named IFI78 (interferon-inducible protein $\mathrm{p} 78$ ), encodes a member of the dynamin superfamily of large GTPases, which mediates vesicle trafficking and organelle homeostasis [37]. Similarly to other Mx proteins, human MX1 has antiviral activities against several RNA viruses and is transcriptionally induced by interferon through the JAK/STAT pathway [38]. $M X 1$ is upregulated in cells of some Fanconi anemia complementation groups, which may be related to phenotypic features of this disease, particularly bone marrow failure [23]. $M X 1$ is downregulated in prostate carcinomas [39] and methylated in acute myeloid leukemia cells [40], which provide a potential link between $M X 1$ silencing and tumorigenesis. Supporting this link are the observations by Mibayashi et al. [41] that MX1 promotes cell death induced by apoptotic stimuli. Therefore, low levels of MX1 protein might contribute to apoptosis resistance during cancer development.

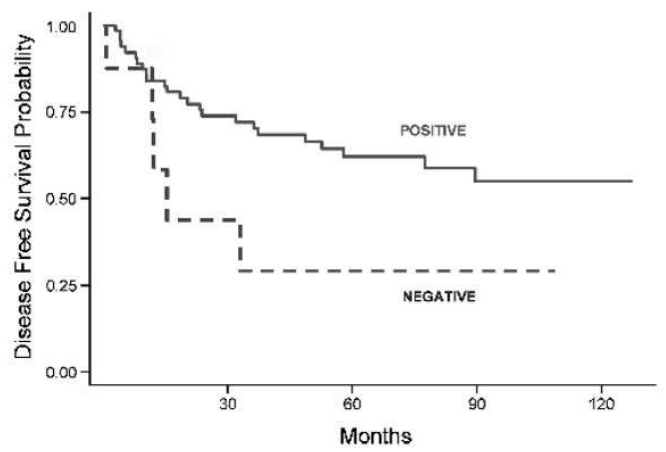

Figure 5. Kaplan-Meier disease-free survival estimates from 73 patients for CRABP2 expression. Continuous and dashed lines depict patients with positive (weak and strong) or negative CRABP2 expression $(P=.0531)$, respectively. 
CRABP2 (cellular retinoic acid binding protein 2) encodes a small protein $(15 \mathrm{kDa})$ harboring a lipocalin domain involved in retinoic acid (RA) binding $[42,43]$. CRABP2 binds to all-trans RA in the cytoplasm, which triggers its nuclear targeting to associate with RA receptors (RARs). Owing to the poor water solubility of RA, its binding by CRABP2 allows the intracellular RA levels and availability to increase [44]. The association between CRABP2 and RAR in the nucleus enables direct channeling of RA and increases the RAR-RXR heterodimer transcriptional activity at RA-responsive sites [44].

$\mathrm{RA}$ and its derivatives (retinoids) are responsible for the regulation of multiple biologic processes, such as embryogenesis, apoptosis, cell proliferation, and differentiation [45]. Several authors have described retinoids as useful pharmaceuticals for the prevention and treatment of various types of human cancer. These studies demonstrated their efficiency in the treatment of tumors of head and neck $[46,47]$, lung [48], skin [49], breast [50], and also of acute promyelocytic leukemia [51]. However, development of RA resistance frequently occurs [52]. Importantly, two major RA pathways were described as responsible for the antiproliferative and proliferative effects observed, respectively: the classic CRABP2/RAR and, more recently described, the FABP5/ PPAR $\beta / \delta$ [53]. Therefore, both endogenous and exogenous retinoids may only inhibit tumor growth if the RAR pathway is predominant in the tumor cells, and this idea is supported by data showing that diverting RA from PPAR $\beta / \delta$ to RAR is sufficient to overcome RA resistance of mammary carcinomas [54]. In a related manner, abnormalities in the expression or in the function of retinoid receptors, particularly the suppression of RARB expression, have been found in several types of cancer, including premalignant oral lesions [55] and HNSCC [56,57]. Interestingly, CRABP2 mRNA and protein levels were shown to be downregulated in carcinoma cells, relative to normal glandular cells, in the prostate $[58,59]$. Also, CRABP2 was identified as downregulated in an oligomicroarray analysis of genes related to lymph node metastasis in esophageal squamous cell carcinoma [60]. More recently, CRABP2 expression was demonstrated to be suppressed as a result of promoter DNA methylation in non-small cell lung tumor [61].

Finally, in confirmation that CRABP2 is an important component of the antiproliferative effects of the RAR pathway in response to RA, it was shown that CRABP2 induces apoptosis in MCF-7 mammary carcinoma cells because of the induction of transcription of cell cycleregulating genes $[62,63]$ and that overexpression of $C R A B P 2$ in the $\mathrm{HaCaT}$ keratinocyte cell line significantly increased tumor necrosis factor $\alpha$-induced apoptosis [53]. The correlation of CRABP2 protein with the antiproliferative effect of RA and the induction of apoptosis in various cells are in agreement with the results of our study showing that $C R A B P 2$ expression loss leads to survival disadvantage.

In the present study, we have demonstrated for the first time that $C R A B P 2$ and $M X 1$ mRNA expression is regulated by DNA methylation and that hypermethylation of both genes is frequent among HNSCC. Although a direct correlation between CRABP2 hypermethylatin and absence of protein expression was not directly evaluated in the present work, we observed similar frequencies for both CRABP2 hypermethylation (region $2-10.2 \%$ ) and absence of CRABP2 protein $(11.0 \%)$ in different sets of HNSCC samples, suggesting that DNA hypermethylation might also affect CRABP2 protein levels. Moreover, a statistically significant association between absence of CRABP2 protein and lower survival rates was observed in our study, suggesting that CRABP2 could be used as a prognostic biomarker for patients with HNSCC.

\section{Acknowledgments}

The authors thank the members of the GENCAPO (Head and Neck Genome) Project for sample collection, initial on-site sample processing, and for providing the epidemiological and pathological data on the cases. The authors also thank FAPESP, CNPq and CAPES for fellowships awarded to M.F.C., R.V.R. and C.M.K.

\section{References}

[1] McMahon S and Chen AY (2003). Head and neck cancer. Cancer Metastasis Rev 22, 21-24.

[2] Goldenberg D, Lee J, Koch WM, Kim MM, Trink B, Sidransky D, and Moon CS (2004). Habitual risk factors for head and neck cancer. Otolaryngol Head Neck Surg 131, 986-993.

[3] Parkin DM, Bray F, Ferlay J, and Pisani P (2005). Global cancer statistics, 2002. CA Cancer J Clin 55, 74-108.

[4] Moriniere S (2006). Epidemiology of head and neck cancer [in French]. Rev Prat 56, $1637-1641$

[5] Jemal A, Siegel R, Ward E, Murray T, Xu J, and Thun MJ (2007). Cancer statistics, 2007. CA Cancer J Clin 57, 43-66.

[6] Brasil (2007). Estimativa 2008: Incidência de Câncer no Brasil. Rio de Janeiro: Ministério da Saúde. Secretaria de Atençāo à Saúde. Brasil: Instituto Nacional do Câncer.

[7] Barnes L, Eveson JW, Reichart P, and Sidransky D (2005). World Health Organization Classification of Tumors. Pathology and Genetics of Head and Neck Tumors. Lyon, France: IARC Press.

[8] Ha PK and Califano JA (2006). Promoter methylation and inactivation of tumoursuppressor genes in oral squamous-cell carcinoma. Lancet Oncol 7, 77-82.

[9] Shaw R (2006). The epigenetics of oral cancer. Int J Oral Maxillofac Surg 35, 101-108.

[10] Hasegawa M, Nelson HH, Peters E, Ringstrom E, Posner M, and Kelsey KT (2002). Patterns of gene promoter methylation in squamous cell cancer of the head and neck. Oncogene 21, 4231-4236.

[11] Calmon MF, Colombo J, Carvalho F, Souza FP, Filho JF, Fukuyama EE, Camargo AA, Caballero OL, Tajara EH, Cordeiro JA, et al. (2007). Methylation profile of genes $C D K N 2 A$ (p14 and p16), DAPK1, CDH1, and ADAM23 in head and neck cancer. Cancer Genet Cytogenet 173, 31-37.

[12] Kozaki K, Imoto I, Mogi S, Omura K, and Inazawa J (2008). Exploration of tumor-suppressive microRNAs silenced by DNA hypermethylation in oral cancer. Cancer Res 68, 2094-2105.

[13] Smith IM, Mydlarz WK, Mithani SK, and Califano JA (2007). DNA global hypomethylation in squamous cell head and neck cancer associated with smoking, alcohol consumption and stage. Int J Cancer 121, 1724-1728.

[14] Richards KL, Zhang B, Baggerly KA, Colella S, Lang JC, Schuller DE, and Krahe R (2009). Genome-wide hypomethylation in head and neck cancer is more pronounced in HPV-negative tumors and is associated with genomic instability. PLOS ONE 4, e4941.

[15] Costello JF, Fruhwald MC, Smiraglia DJ, Rush LJ, Robertson GP, Gao X, Wright FA, Feramisco JD, Peltomaki P, Lang JC, et al. (2000). Aberrant CpG-island methylation has non-random and tumour-type-specific patterns. Nat Genet 24, 132-138.

[16] Esteller M (2007). Cancer epigenomics: DNA methylomes and histone-modification maps. Nat Rev Genet 8, 286-298.

[17] Shames DS, Minna JD, and Gazdar AF (2007). Methods for detecting DNA methylation in tumors: from bench to bedside. Cancer Lett 251, 187-198.

[18] Jones PA and Buckley JD (1990). The role of DNA methylation in cancer. Adv Cancer Res 54, 1-23.

[19] Jiang H, Kang DC, Alexandre D, and Fisher PB (2000). RaSH, a rapid subtraction hybridization approach for identifying and cloning differentially expressed genes. Proc Natl Acad Sci USA 97, 12684-12689.

[20] Ewing B, Hillier L, Wendl MC, and Green P (1998). Base-calling of automated sequencer traces using phred. I. Accuracy assessment. Genome Res 8, 175-185.

[21] Ewing B and Green P (1998). Base-calling of automated sequencer traces using phred. II. Error probabilities. Genome Res 8, 186-194.

[22] Smit AF (1999). Interspersed repeats and other mementos of transposable elements in mammalian genomes. Curr Opin Genet Dev 9, 657-663.

[23] Altschul SF, Madden TL, Schaffer AA, Zhang J, Zhang Z, Miller W, and Lipman DJ (1997). Gapped BLAST and PSI-BLAST: a new generation of protein database search programs. Nucleic Acids Res 25, 3389-3402.

[24] Gomes LI, Silva RL, Stolf BS, Cristo EB, Hirata R, Soares FA, Reis LF, Neves EJ, and Carvalho AF (2003). Comparative analysis of amplified and nonamplified RNA for hybridization in cDNA microarray. Anal Biochem 321, 244-251. 
[25] Maschietto M, de Camargo B, Brentani H, Grundy P, Sredni ST, Torres C, Mota LD, Cunha IW, Patrao DF, Costa CM, et al. (2008). Molecular profiling of isolated histological components of wilms tumor implicates a common role for the Wnt signaling pathway in kidney and tumor development. Oncology 75 , $81-91$.

[26] Vencio RZ and Koide T (2005). HTself: self-self based statistical test for low replication microarray studies. DNA Res 12, 211-214.

[27] Gardiner-Garden $M$ and Frommer $M$ (1987). CpG islands in vertebrate genomes. J Mol Biol 196, 261-282.

[28] Pfaffl MW (2001). A new mathematical model for relative quantification in real-time RT-PCR. Nucleic Acids Res $\mathbf{2 9}$, e45.

[29] Vandesompele J, De Preter K, Pattyn F, Poppe B, Van Roy N, De Paepe A, and Speleman F (2002). Accurate normalization of real-time quantitative RT-PCR data by geometric averaging of multiple internal control genes. Genome Biol 3; RESEARCH0034.

[30] Herman JG, Graff JR, Myohanen S, Nelkin BD, and Baylin SB (1996). Methylationspecific PCR: a novel PCR assay for methylation status of CPG islands. Proc Natl Acad Sci USA 93, 9821-9826.

[31] Liang G, Gonzales FA, Jones PA, Orntoft TF, and Thykjaer T (2002). Analysis of gene induction in human fibroblasts and bladder cancer cells exposed to the methylation inhibitor 5-aza-2'-deoxycytidine. Cancer Res 62, 961-966.

[32] Suzuki H, Gabrielson E, Chen W, Anbazhagan R, van Engeland M, Weijenberg MP, Herman JG, and Baylin SB (2002). A genomic screen for genes upregulated by demethylation and histone deacetylase inhibition in human colorectal cancer. Nat Genet 31, 141-149.

[33] Yamashita K, Upadhyay S, Osada M, Hoque MO, Xiao Y, Mori M, Sato F, Meltzer SJ, and Sidransky D (2002). Pharmacologic unmasking of epigenetically silenced tumor suppressor genes in esophageal squamous cell carcinoma. Cancer Cell 2, 485-495.

[34] Sato N, Fukushima N, Maitra A, Matsubayashi $\mathrm{H}$, Yeo CJ, Cameron JL, Hruban $\mathrm{RH}$, and Goggins M (2003). Discovery of novel targets for aberrant methylation in pancreatic carcinoma using high-throughput microarrays. Cancer Res 63 , $3735-3742$.

[35] Lodygin D, Epanchintsev A, Menssen A, Diebold J, and Hermeking H (2005). Functional epigenomics identifies genes frequently silenced in prostate cancer. Cancer Res 65, 4218-4227.

[36] Wei SH, Chen CM, Strathdee G, Harnsomburana J, Shyu CR, Rahmatpanah F, Shi H, Ng SW, Yan PS, Nephew KP, et al. (2002). Methylation microarray analysis of late-stage ovarian carcinomas distinguishes progression-free survival in patients and identifies candidate epigenetic markers. Clin Cancer Res 8, 2246-2252.

[37] Haller O, Staeheli P, and Kochs G (2007). Interferon-induced Mx proteins in antiviral host defense. Biochimie 89, 812-818.

[38] Holzinger D, Jorns C, Stertz S, Boisson-Dupuis S, Thimme R, Weidmann M, Casanova JL, Haller O, and Kochs G (2007). Induction of $M x A$ gene expression by influenza A virus requires type I or type III interferon signaling. J Virol $\mathbf{8 1}$, 7776-7785.

[39] Schulz WA, Alexa A, Jung V, Hader C, Hoffmann MJ, Yamanaka M, Fritzsche S, Wlazlinski A, Muller M, Lengauer T, et al. (2007). Factor interaction analysis for chromosome 8 and DNA methylation alterations highlights innate immune response suppression and cytoskeletal changes in prostate cancer. Mol Cancer 6, 14.

[40] Desmond JC, Raynaud S, Tung E, Hofmann WK, Haferlach T, and Koeffler HP (2007). Discovery of epigenetically silenced genes in acute myeloid leukemias. Leukemia 21, 1026-1034.

[41] Mibayashi M, Nakad K, and Nagata K (2002). Promoted cell death of cells expressing human MxA by influenza virus infection. Microbiol Immunol 46, $29-36$.

[42] Astrom A, Tavakkol A, Pettersson U, Cromie M, Elder JT, and Voorhees JJ (1991). Molecular cloning of two human cellular retinoic acid-binding proteins (CRABP). Retinoic acid-induced expression of CRABP-II but not CRABP-I in adult human skin in vivo and in skin fibroblasts in vitro. J Biol Chem 266, $17662-17666$.

[43] Banaszak L, Winter N, Xu Z, Bernlohr DA, Cowan S, and Jones TA (1994). Lipid-binding proteins: a family of fatty acid and retinoid transport proteins. Adv Protein Chem 45, 89-151
[44] Budhu AS and Noy N (2002). Direct channeling of retinoic acid between cellular retinoic acid-binding protein II and retinoic acid receptor sensitizes mammary carcinoma cells to retinoic acid-induced growth arrest. Mol Cell Biol 22, 2632-2641.

[45] De Luca LM (1991). Retinoids and their receptors in differentiation, embryogenesis, and neoplasia. Faseb J 5, 2924-2933.

[46] Hong WK, Lippman SM, Itri LM, Karp DD, Lee JS, Byers RM, Schantz SP, Kramer AM, Lotan R, Peters LJ, et al. (1990). Prevention of second primary tumors with isotretinoin in squamous-cell carcinoma of the head and neck. $N$ Engl J Med 323, 795-801.

[47] Jetten AM, Kim JS, Sacks PG, Rearick JI, Lotan D, Hong WK, and Lotan R (1990). Inhibition of growth and squamous-cell differentiation markers in cultured human head and neck squamous carcinoma cells by $\beta$-all-trans retinoic acid. Int J Cancer 45, 195-202.

[48] Pastorino U, Infante M, Maioli M, Chiesa G, Buyse M, Firket P, Rosmentz N, Clerici M, Soresi E, Valente M, et al. (1993). Adjuvant treatment of stage I lung cancer with high-dose vitamin A. J Clin Oncol 11, 1216-1222.

[49] Kraemer KH, DiGiovanna JJ, Moshell AN, Tarone RE, and Peck GL (1988). Prevention of skin cancer in xeroderma pigmentosum with the use of oral isotretinoin. N Engl J Med 318, 1633-1637.

[50] Jing Y, Waxman S, and Mira-y-Lopez R (1997). The cellular retinoic acid binding protein II is a positive regulator of retinoic acid signaling in breast cancer cells. Cancer Res 57, 1668-1672.

[51] Chomienne C, Fenaux P, and Degos L (1996). Retinoid differentiation therapy in promyelocytic leukemia. FASEB J 10, 1025-1030.

[52] Garattini E, Gianni M, and Terao M (2007). Retinoids as differentiating agents in oncology: a network of interactions with intracellular pathways as the basis for rational therapeutic combinations. Curr Pharm Des 13, 1375-1400.

[53] Schug TT, Berry DC, Shaw NS, Travis SN, and Noy N (2007). Opposing effects of retinoic acid on cell growth result from alternate activation of two different nuclear receptors. Cell 129, 723-733.

[54] Schug TT, Berry DC, Toshkov IA, Cheng L, Nikitin AY, and Noy N (2008). Overcoming retinoic acid-resistance of mammary carcinomas by diverting retinoic acid from PPAR $\beta / \delta$ to RAR. Proc Natl Acad Sci USA 105, 7546-7551.

[55] Hu L, Crowe DL, Rheinwald JG, Chambon P, and Gudas LJ (1991). Abnormal expression of retinoic acid receptors and keratin 19 by human oral and epidermal squamous cell carcinoma cell lines. Cancer Res 51, 3972-3981.

[56] Zou CP, Clifford JL, Xu XC, Sacks PG, Chambon P, Hong WK, and Lotan R (1994). Modulation by retinoic acid (RA) of squamous cell differentiation, cellular RA-binding proteins, and nuclear RA receptors in human head and neck squamous cell carcinoma cell lines. Cancer Res 54, 5479-5487.

[57] Youssef EM, Lotan D, Issa JP, Wakasa K, Fan YH, Mao L, Hassan K, Feng L, Lee JJ, Lippman SM, et al. (2004). Hypermethylation of the retinoic acid receptor$\beta(2)$ gene in head and neck carcinogenesis. Clin Cancer Res 10, 1733-1742.

[58] Okuducu AF, Janzen V, Ko Y, Hahne JC, Lu H, Ma ZL, Albers P, Sahin A, Wellmann A, Scheinert P, et al. (2005). Cellular retinoic acid-binding protein 2 is down-regulated in prostate cancer. Int J Oncol 27, 1273-1282.

59] Thompson M, Lapointe J, Choi YL, Ong DE, Higgins JP, Brooks JD, and Pollack JR (2008). Identification of candidate prostate cancer genes through comparative expression-profiling of seminal vesicle. Prostate 68, 1248-1256.

[60] Uchikado $\mathrm{Y}$, Inoue $\mathrm{H}$, Haraguchi N, Mimori K, Natsugoe S, Okumura H, Aikou T, and Mori M (2006). Gene expression profiling of lymph node metastasis by oligomicroarray analysis using laser microdissection in esophageal squamous cell carcinoma. Int J Oncol 29, 1337-1347.

[61] Park JC, Chae YK, Son CH, Kim MS, Lee J, Ostrow K, Sidransky D, Hoque $\mathrm{MO}$, and Moon C (2008). Epigenetic silencing of human T (brachyury homologue) gene in non-small-cell lung cancer. Biochem Biophys Res Commun 365 , 221-226.

[62] Donato LJ and Noy N (2005). Suppression of mammary carcinoma growth by retinoic acid: proapoptotic genes are targets for retinoic acid receptor and cellular retinoic acid-binding protein II signaling. Cancer Res 65, 8193-8199.

[63] Donato LJ, Suh JH, and Noy N (2007). Suppression of mammary carcinoma cell growth by retinoic acid: the cell cycle control gene $B \operatorname{tg} 2$ is a direct target for retinoic acid receptor signaling. Cancer Res 67, 609-615. 
Table W1. List of the 181 Reactivated Genes after 5Aza-dC Treatment Identified by RaSH Table W1. (continued) cDNA Library.

\begin{tabular}{|c|c|c|c|}
\hline Sequence & Official Symbol & CpG Island & Spotred in Array \\
\hline CV341138 & - & Yes & Yes \\
\hline NM_000700 & ANXAI & No & Yes \\
\hline NM_001008897 & $T C P I$ & Yes & Yes \\
\hline NM_002462 & $M X I$ & Yes & Yes \\
\hline NM_005562 & LAMC2 & No & Yes \\
\hline NM_005347 & HSPAS & Yes & Yes \\
\hline NM_004509 & SP110 & Yes & No \\
\hline NM_005610 & RBBPA & Yes & Yes \\
\hline NM_001001977 & ATPSE & Yes & Yes \\
\hline NM_022073 & EGLN3 & Yes & Yes \\
\hline NM_006476 & ATP5L & Yes & Yes \\
\hline NM_002893 & RBBP7 & Yes & No \\
\hline NM_001799 & $C D K 7$ & Yes & Yes \\
\hline NM_016237 & ANAPC5 & Yes & Yes \\
\hline NM_002463 & $M \times 2$ & Yes & Yes \\
\hline NM_001852 & COL9A2 & Yes & No \\
\hline NM_022121 & PERP & Yes & Yes \\
\hline NM_001012456 & SEC6IG & Yes & Yes \\
\hline NM_002535 & OAS2 & Yes & No \\
\hline NM_015013 & $A O F 2$ & Yes & Yes \\
\hline NM_006135 & CAPZAI & Yes & Yes \\
\hline NM_018835 & $\mathrm{RC} 3 \mathrm{H} 2$ & Yes & No \\
\hline NM_144596 & TTC8 & Yes & No \\
\hline NM_002227 & JAKI & No & Yes \\
\hline NM_014352 & $P O U 2 F 3$ & Yes & Yes \\
\hline NM_004923 & MTL5 & Yes & Yes \\
\hline NM_003406 & YWHAZ & Yes & Yes \\
\hline NM_001007074 & RPL32 & Yes & Yes \\
\hline NM_033407 & $D O C K 7$ & Yes & No \\
\hline NM_001686 & $A T P 5 B$ & Yes & Yes \\
\hline NM_017688 & BSPRY & Yes & Yes \\
\hline NM_000979 & RPL18 & Yes & No \\
\hline NM_005056 & JARIDIA & No & Yes \\
\hline NM_020675 & $S P C 25$ & Yes & Yes \\
\hline NM_004371 & COPA & Yes & No \\
\hline NM_012420 & IFIT5 & Yes & Yes \\
\hline NM_019606 & $M E P C E$ & Yes & Yes \\
\hline NM_015091 & FAM179B & Yes & Yes \\
\hline NM_014612 & FAMI20A & Yes & No \\
\hline NM_139266 & STATI & Yes & Yes \\
\hline NM_014969 & WDR47 & Yes & Yes \\
\hline NM_006004 & UQCRH & Yes & Yes \\
\hline NM_006819 & STIPI & Yes & Yes \\
\hline NM_004487 & GOLGBI & Yes & Yes \\
\hline NM_002421 & MMP1 & No & No \\
\hline NM_006603 & STAG2 & Yes & Yes \\
\hline NM_015340 & LARS2 & Yes & Yes \\
\hline NM_000602 & SERPINEI & No & Yes \\
\hline NM_198076 & FAM36A & Yes & Yes \\
\hline NM_003746 & DYNLLI & Yes & Yes \\
\hline NM_005782 & THOC4 & Yes & Yes \\
\hline NM_018660 & ZNF395 & Yes & Yes \\
\hline NM_003792 & $E D F I$ & Yes & Yes \\
\hline NM_005381 & $N C L$ & Yes & Yes \\
\hline NM_005762 & TRIM28 & Yes & Yes \\
\hline NM_002231 & CD82 & Yes & Yes \\
\hline NM_002797 & PSMBS & No & Yes \\
\hline NM_001748 & CAPN2 & Yes & No \\
\hline NM_001009925 & C20orf3o & Yes & Yes \\
\hline NM_000646 & $A G L$ & Yes & Yes \\
\hline NM_183356 & ASNS & Yes & Yes \\
\hline NM_005100 & AKAPI2 & Yes & Yes \\
\hline NM_006421 & ARFGEFI & Yes & No \\
\hline NM_198829 & $R A C l$ & Yes & Yes \\
\hline NM_006931 & $S L C 2 A 3$ & No & Yes \\
\hline NM_000366 & TPMI & Yes & Yes \\
\hline NM_005365 & MAGEA9 & No & Yes \\
\hline NM_006815 & TMED2 & Yes & Yes \\
\hline NM_022754 & SFXNI & Yes & Yes \\
\hline NM_004755 & RPSGKAS & Yes & Yes \\
\hline NM_015382 & HECTDI & Yes & No \\
\hline NM_005243 & EWSRI & Yes & Yes \\
\hline
\end{tabular}

\begin{tabular}{|c|c|c|c|}
\hline Sequence & Official Symbol & CpG Island & Spotted in Array \\
\hline NM_004130 & $G Y G 1$ & Yes & Yes \\
\hline NM_153649 & TPM3 & Yes & Yes \\
\hline NM_021101 & $C L D N$ & Yes & Yes \\
\hline NM_006549 & CAMKK2 & Yes & Yes \\
\hline NM_001175 & ARHGDIB & No & Yes \\
\hline NM_002673 & PLXNBI & Yes & Yes \\
\hline NM_198147 & LOC116236 & Yes & Yes \\
\hline NM_014758 & $S N X 19$ & Yes & Yes \\
\hline NM_016565 & CHCHD8 & Yes & Yes \\
\hline NM_020914 & RNF213 & Yes & No \\
\hline NM_000576 & $I L 1 B$ & No & Yes \\
\hline NM_005388 & PDCL & Yes & No \\
\hline NM_001080 & $A L D H 5 A I$ & Yes & Yes \\
\hline NM_014611 & $M D N I$ & Yes & No \\
\hline NM_015509 & NECAPI & Yes & Yes \\
\hline NM_003932 & ST13 & Yes & Yes \\
\hline NM_002274 & KRTI3 & No & Yes \\
\hline NM_005789 & PSME3 & Yes & Yes \\
\hline NM_182972 & $I R F 2 B P 2$ & Yes & No \\
\hline NM_004859 & CLTC & Yes & Yes \\
\hline NM_133337 & FERIL3 & Yes & Yes \\
\hline NM_178868 & CMTM8 & Yes & Yes \\
\hline NM_018043 & ANOI & Yes & Yes \\
\hline NM_003405 & YWHAH & Yes & Yes \\
\hline NM_016816 & $O A S I$ & Yes & Yes \\
\hline NM_001457 & $F L N B$ & Yes & Yes \\
\hline NM_003670 & BHLHB2 & Yes & Yes \\
\hline NM_014014 & $A S C C 3 L I$ & Yes & No \\
\hline NM_002094 & GSPTI & Yes & No \\
\hline NM_002080 & GOT2 & Yes & Yes \\
\hline NM_005113 & GOLGAS & Yes & Yes \\
\hline NM_032547 & $S C O C$ & Yes & Yes \\
\hline NM_000526 & KRTI4 & No & No \\
\hline NM_203459 & CAMSAPIL & Yes & Yes \\
\hline NM_030920 & ANP32E & Yes & Yes \\
\hline NM_015575 & GIGYF2 & Yes & Yes \\
\hline NM_005744 & ARIHI & Yes & Yes \\
\hline NM_032565 & $E B P L$ & Yes & Yes \\
\hline NM_177423 & PPFIAI & Yes & Yes \\
\hline NM_000989 & RPL3O & Yes & Yes \\
\hline NM_014752 & SPCS2 & Yes & Yes \\
\hline NM_201517 & $H 2 A F V$ & Yes & Yes \\
\hline XM_031689 & - & Yes & Yes \\
\hline NM_031430 & RILP & Yes & No \\
\hline NM_213646 & WARS & Yes & No \\
\hline NM_001975 & ENO2 & Yes & No \\
\hline NM_032940 & POLR2C & Yes & Yes \\
\hline NM_032366 & C16orfl3 & Yes & Yes \\
\hline NM_024881 & SLCBSEI & Yes & Yes \\
\hline NM_005389 & PCMT1 & Yes & Yes \\
\hline NM_020899 & ZBTBA & Yes & Yes \\
\hline NM_002822 & TWFI & Yes & Yes \\
\hline NM_016582 & $S L C 15 A 3$ & Yes & Yes \\
\hline NM_016286 & $D C X R$ & Yes & Yes \\
\hline NM_001614 & ACTGI & Yes & Yes \\
\hline NM_001878 & $C R A B P 2$ & Yes & Yes \\
\hline NM_144570 & $H N I L$ & Yes & Yes \\
\hline NM_002272 & KRT4 & No & Yes \\
\hline NM_001539 & DNAJAI & Yes & Yes \\
\hline NM_018156 & VPS13D & Yes & Yes \\
\hline NM_001005340 & GPNMB & Yes & Yes \\
\hline NM_003039 & SLC2AS & Yes & Yes \\
\hline NM_003467 & CXCR4 & Yes & Yes \\
\hline NM_000661 & RPL9 & Yes & Yes \\
\hline NM_014831 & $L B A I$ & Yes & No \\
\hline NM_017830 & OCIADI & Yes & Yes \\
\hline NM_007146 & $V E Z F 1$ & Yes & Yes \\
\hline NM_016091 & EIF3EIP & Yes & Yes \\
\hline NM_001331 & $C T N N D$ & Yes & No \\
\hline NM_013230 & $C D 24$ & Yes & Yes \\
\hline NM_005556 & KRT7 & Yes & Yes \\
\hline NM_002211 & $I T G B I$ & Yes & No \\
\hline NM_031899 & GORASPI & Yes & Yes \\
\hline
\end{tabular}


Table W1. (continued)

\begin{tabular}{llll}
\hline Sequence & Official Symbol & CpG Island & Spotted in Array \\
\hline NM_003972 & BTAFI & Yes & Yes \\
NM_016284 & CNOT1 & Yes & Yes \\
NM_006362 & NXFI & Yes & Yes \\
NM_006018 & GPRI09B & No & Yes \\
NM_181777 & UBE2A & Yes & Yes \\
NM_006306 & SMC1A & Yes & Yes \\
NM_013236 & ATXN10 & Yes & Yes \\
NM_015384 & NIPBL & Yes & Yes \\
NM_002828 & PTPN2 & Yes & No \\
NM_018127 & ELAC2 & Yes & Yes \\
NM_002880 & RAF1 & Yes & Yes \\
NM_001008493 & ENAH & Yes & Yes \\
NM_025137 & SPG11 & Yes & Yes \\
BC038574 & - & Yes & Yes \\
NM_003376 & VEGFA & Yes & No \\
NM_001025 & RPS23 & Yes & No \\
CV571660 & - & Yes & Yes \\
CV411881 & - & Yes & Yes \\
AL523333 & - & Yes & Yes \\
NM_005121 & MEDI3 & Yes & Yes \\
NM_016072 & GOLT1B & Yes & Yes \\
NM_004966 & HNRPF & Yes & Yes \\
NM_015630 & EPC2 & Yes & Yes \\
NM_001002857 & ANXA2 & Yes & Yes \\
NM_016520 & C9orf78 & Yes & Yes \\
NM_006472 & TXNIP & No & Yes \\
NM_003324 & TULP3 & Yes & Yes \\
NM_201281 & MTMR2 & Yes & Yes \\
NM_006796 & AFG3L2 & Yes & Yes \\
NM_005358 & LMO7 & Yes & Yes \\
BC027471 & - & Yes & Yes \\
BM685726 & - & Yes & Yes \\
NM_182926 & KTN1 & Yes & Yes \\
NM_001087 & AAMP & Yes & Yes \\
NM_001008844 & DSP & Yes & Yes \\
AW105461 & - & Yes & Yes \\
\hline & & & \\
\hline
\end{tabular}

Table W2. Validation of Gene Expression Reactivation by qRT-PCR in 5Aza-dC-Treated HNSCC Cell Lines.

\begin{tabular}{|c|c|c|c|c|}
\hline \multirow[t]{2}{*}{ Official Symbol } & \multicolumn{4}{|c|}{ Cell Lines } \\
\hline & $\mathrm{FaDu}$ & UM-SCC-14A & UM-SCC-17A & UM-SCC-38A \\
\hline AAMP & 1.7 & 1.7 & ND & ND \\
\hline ACTGI & ND & ND & 0.8 & 0.6 \\
\hline$A F G 3 L 2$ & ND & ND & 1.0 & 0.5 \\
\hline ASNS & ND & ND & 1.1 & 0.3 \\
\hline ATP5E & 0.8 & 1.7 & 1.6 & ND \\
\hline ATXN1O & ND & ND & 0.9 & 0.4 \\
\hline CAPZAI & ND & 2.5 & 1.7 & ND \\
\hline CLDNI & 1.9 & 2.4 & ND & ND \\
\hline$C R A B P 2$ & 4.6 & 1.9 & 1.7 & 0.4 \\
\hline$D C X R$ & ND & ND & 1.3 & 1.1 \\
\hline EIF3EIP & ND & ND & 1.0 & 0.8 \\
\hline$E P C 2$ & 1.3 & ND & ND & 0.7 \\
\hline MEPCE & 0.9 & ND & 1.5 & 1.7 \\
\hline GOT2 & 0.6 & 1.1 & ND & ND \\
\hline HNRPF & ND & ND & 0.8 & 0.5 \\
\hline KTNI & ND & ND & 1.2 & 2.7 \\
\hline MED13 & 1.3 & 1.8 & ND & ND \\
\hline$M X I$ & 22.4 & 4.5 & ND & 0.2 \\
\hline OCLADI & 1.1 & ND & 1.4 & 0.7 \\
\hline PCMT1 & 0.9 & ND & 1.2 & ND \\
\hline PERP & 2.1 & 1.7 & ND & ND \\
\hline PLXNBI & 1.8 & ND & ND & 0.3 \\
\hline PSME3 & ND & ND & 1.0 & 0.6 \\
\hline$R A C I$ & 1.3 & ND & 1.1 & ND \\
\hline$R A F I$ & ND & ND & 1.2 & 1.1 \\
\hline RPL 30 & ND & 1.3 & 1.1 & 0.6 \\
\hline SFXNI & 0.7 & ND & 1.3 & 0.6 \\
\hline SLC15A3 & 7.3 & 2.2 & 1.0 & 3.0 \\
\hline SPG11 & 1.0 & 2.0 & 1.0 & ND \\
\hline STAG2 & 1.4 & ND & 1.9 & 1.8 \\
\hline THOC4 & ND & ND & 0.8 & 0.8 \\
\hline TNRC15 & 0.8 & ND & ND & 0.7 \\
\hline UQCRH & ND & 1.6 & 1.3 & ND \\
\hline WDRA7 & 1.5 & ND & 1.6 & 0.4 \\
\hline YWHAH & ND & ND & 0.9 & 1.0 \\
\hline
\end{tabular}

ND indicates not determined. 
Table W3. Distribution of the HNSCC Cases According to Demographic, Lifestyle, and Clinicopathological Variables

\begin{tabular}{lllr}
\hline Variables & Caregory & TMA, $n(\%)$ & MSP, $n(\%)$ \\
\hline Age & $\leq 53$ & $14(19.18)$ & $51(36.43)$ \\
& $>53$ & $59(80.82)$ & $89(63.57)$ \\
Tumor site & Oral cavity & $23(30.67)$ & $64(45.71)$ \\
& Larynx & $31(41.33)$ & $24(17.14)$ \\
Tumor size & Hypopharynx & $21(28.00)$ & $52(37.14)$ \\
& T1 + T2 & $22(33.85)$ & $34(25.37)$ \\
Lymph nodes & T3+ T4 & $43(66.15)$ & $100(74.63)$ \\
& No & $8(11.43)$ & $26(19.40)$ \\
Grade & N+ & $62(88.57)$ & $108(80.60)$ \\
& 1 & $25(34.24)$ & $36(27.48)$ \\
Vascular invasion & 2 & $41(56.16)$ & $77(58.78)$ \\
& 3 & $7(9.60)$ & $18(13.74)$ \\
Lymphatic permeation & No & $57(79.17)$ & $115(86.47)$ \\
& Yes & $15(20.83)$ & $18(13.53)$ \\
Perineural infiltration & No & $46(63.89)$ & $87(64.93)$ \\
& Yes & $26(36.11)$ & $47(35.07)$ \\
& No & $40(55.56)$ & $69(51.88)$ \\
& Yes & $32(44.44)$ & $64(48.12)$ \\
\hline
\end{tabular}

\begin{tabular}{|c|c|c|c|}
\hline Official Symbol & Sense & Sequence $\left(5^{\prime} \rightarrow 3^{\prime}\right)$ & $\mu \mathrm{M}$ \\
\hline \multirow[t]{2}{*}{ AAMP } & Forward & CACCTTTGCATTGCACTCAG & 0.4 \\
\hline & Reverse & TATGGCCTGCACACTCAAAG & \\
\hline \multirow[t]{2}{*}{ ACTGI } & Forward & AGCCTTCCTTCCTGGGTATG & 0.5 \\
\hline & Reverse & TGTTGGCGTACAGGTCTTTG & \\
\hline \multirow[t]{2}{*}{$A F G 3 L 2$} & Forward & ACGAGGTGGCAAGAAAGATG & 0.4 \\
\hline & Reverse & ATGACTCCACCCCAGAACAG & \\
\hline \multirow[t]{2}{*}{ ASNS } & Forward & AAGACAGCCCCGATTTACTG & 0.5 \\
\hline & Reverse & AGAGCCTGAATGCCTTCCTC & \\
\hline \multirow[t]{2}{*}{ ATPSE } & Forward & TGGCAGCAACGTAAAAATTTG & 0.4 \\
\hline & Reverse & ACATGTGCCCACACATCTTC & \\
\hline \multirow[t]{2}{*}{ ATXN1O } & Forward & GCGAGTGGAACAGGAATCTC & 0.5 \\
\hline & Reverse & AGTTCTGGGAAAGCATGCAC & \\
\hline \multirow[t]{2}{*}{ CAPZAI } & Forward & TCGGATGAGGAGAAGGTACG & 0.5 \\
\hline & Reverse & СССTTCCCTGAGGAGATTG & \\
\hline \multirow[t]{2}{*}{ CLDNI } & Forward & GGTGCAGAAGATGAGGATGG & 0.4 \\
\hline & Reverse & CATTGACTGGGGTCATAGGG & \\
\hline \multirow[t]{2}{*}{$C R A B P 2$} & Forward & GACCTCGTGGACCAGAGAACTG & 0.4 \\
\hline & Reverse & CCTGGTGCACACAACGTCAT & \\
\hline \multirow[t]{2}{*}{$D C X R$} & Forward & GGCCTTTGACAGATCCTTTG & 0.5 \\
\hline & Reverse & AGCACTGGCTGGAGACATTC & \\
\hline \multirow[t]{2}{*}{ EIF3EIP } & Forward & ACTACCAGGCCATCAAGGTG & 0.5 \\
\hline & Reverse & GATGGCATCCTGGTAACGAC & \\
\hline \multirow[t]{2}{*}{ EPC2 } & Forward & GCAAGGACATGCCTGATCTC & 0.4 \\
\hline & Reverse & TTGCTGTGCTGAAATTGCTC & \\
\hline GOT2 & Forward & AATGTTTGCCTCTGCCAATC & 0.4 \\
\hline & Reverse & CATCCGCATCITTGCAGAC & \\
\hline HNRPF & Forward & GCCTGGTAGCAACAGAAACC & 0.5 \\
\hline & Reverse & CAGGTGATCTTGGGTGTGG & \\
\hline KTNI & Forward & GTTTCCCCAGAAACGGAGTC & 0.5 \\
\hline & Reverse & TGTGAGCTGTTGGTTTACCG & \\
\hline MEDI3 & Forward & TGAAGAGCATATCACCCTTGC & 0.4 \\
\hline & Reverse & TTGAATGCCTGTCCTGTGAG & \\
\hline MEPCE & Forward & CAACCCTGGTCGTCGTATG & 0.4 \\
\hline & Reverse & CTGGCTTCAATTGGATTCG & \\
\hline MXI & Forward & CAATCAGCCTGCTGACATTG & 0.4 \\
\hline & Reverse & TGTCTCCTGCCTCTGGATG & \\
\hline OCIADI & Forward & GAATGGGAGGGCTGATTTTC & 0.4 \\
\hline & Reverse & TGCATTCTGCGAAGACTCTC & \\
\hline PCMTI & Forward & CTACAGACCGCTCCСACTATG & 0.6 \\
\hline & Reverse & GGAGCACTGATTGTTGCTTG & \\
\hline PERP & Forward & TACGAGGAGGGCTGTCAGAG & 0.4 \\
\hline & Reverse & GGCGAAGAAGGAGAGGATG & \\
\hline PLXNBI & Forward & TGGTTGCAAGCCATCAGAG & 0.4 \\
\hline & Reverse & СTCTTGCAGGAGGGTCTGG & \\
\hline PSME3 & Forward & CCAAGGAACCAAGGTGTTTG & 0.5 \\
\hline & Reverse & TGGGAATCAGGAGCTGTACC & \\
\hline RACI & Forward & TGCTTTTCCCTTGTGAGTCC & 0.4 \\
\hline & Reverse & ATGGGAGTGTTGGGACAGTG & \\
\hline RAFI & Forward & GCCGAACAAGCAAAGAACAG & 0.5 \\
\hline & Reverse & AACACTGCACAGCACTCTGG & \\
\hline RPL3O & Forward & CCTGGGGTACAAGCAGACTC & 0.4 \\
\hline & Reverse & TGATGGACACCAGTTTTAGCC & \\
\hline SFXNI & Forward & GCAAGTTGTCGTGTCCAGGATT & 0.6 \\
\hline & Reverse & TTCCAAAGTGTTCATAATGAATGG & \\
\hline SLCI5A3 & Forward & AAGCTCGCTCTCCAAAACTG & 0.4 \\
\hline & Reverse & GCACATTGACGGTCTCTGG & \\
\hline SPGII & Forward & TCTCCCCAGGATAAGTCCAG & 0.4 \\
\hline & Reverse & GAGGGCTTCAGGGGAATATG & \\
\hline STAG2 & Forward & AAACCAAAAGCAAGGCAAAG & 0.4 \\
\hline & Reverse & GGTTTTCCTCCTCCATTTCC & \\
\hline THOCA & Forward & CTCAGACGCCGATATTCAGG & 0.5 \\
\hline & Reverse & CTCAAAGTGCACGTCTGCTG & \\
\hline TNRC15 & Forward & CTCCAGGAGGAACCCCTTC & 0.6 \\
\hline & Reverse & TCCTCCTCGTCCTGTCAATC & \\
\hline UQCRH & Forward & CGGAGGAGCTCTTTGACTTC & 0.5 \\
\hline & Reverse & TGCCCAGATGATGAAGACTG & \\
\hline WDR47 & Forward & CCAGGGGTACAAAACCTCAG & 0.4 \\
\hline & Reverse & GATAGGCCTCTGTGCATCAAC & \\
\hline YWHAH & Forward & GCGGTGACAGAGCTGAATG & 0.5 \\
\hline & Reverse & TGGTTTTCTGCTCAATGCTG & \\
\hline
\end{tabular}

Table W4. Sequence and Concentration of the Primer Pairs Used in the qRT-PCR Validation of

4




\section{CAPÍTULO 3}

\section{INTRODUÇÃ̃O}

A programação epigenética do genoma é muito importante para o desenvolvimento e o crescimento normal dos mamíferos. Esse mecanismo é essencial para os processos de gametogênese, embriogênese, expressão de genes tecidoespecíficos e silenciamento gênico ( $\mathrm{Li}$ 2002) e, quando alterado está associado com diversas doenças humanas (Robertson 2005; Park, Claus et al. 2011). Os dois principais mecanismos de regulação epigenética relacionada com expressão gênica são a metilação da região promotora dos genes e a modificação das histonas.

\section{METILAÇÃO DO DNA}

A metilação do DNA é um processo complexo pelo qual as metiltransferases de DNA (DNMTs) catalisam a adição de um grupo metil $\left(-\mathrm{CH}_{3}\right)$ do doador universal Sadenosil-L-metionina para a posição carbono-5 das citosinas presentes em posições 5 , de guaninas, formando os dinucleotídeos CpGs. Atualmente, são conhecidas três metiltransferases de DNA em mamíferos, DNMT1, DNMT3A e DNMT3B.

A metilação de citosinas em dinucleotídeos $\mathrm{CpG}$ é a mais prevalente alteração epigenética no genoma mamífero (Hendrich and Bird 2000) e influencia profundamente muitos processos, incluindo regulação transcricional, modulação da estrutura da cromatina, inativação do cromossomo $\mathrm{X}$ e silenciamento de elementos parasitas do DNA (Jones and Laird 1999; Baylin, Esteller et al. 2001; Robertson 2001). Ao contrário, a metilação de citosinas que não estão em dinucleotídeos $\mathrm{CpG}$ é um fenômeno incomum em mamíferos e ocorre somente em células tronco embrionárias.

No genoma humano, estima-se que as citosinas metiladas correspondam a 36\% do total de bases do DNA. Essa proporção vem diminuindo ao longo da evolução, pois muitos dinucleotídeos CpGs foram convertidos em TpGs, por desaminação hidrolítica espontânea (Yoder, Walsh et al. 1997; Egger, Liang et al. 2004). Os sítios CpGs remanescentes apresentam uma alta freqüência de metilação e participam de mudanças na estrutura da cromatina e do bloqueio da transcrição de determinados genes.

A metilação do DNA não está distribuída aleatoriamente no genoma. Ao contrário, regiões discretas, incluindo a maioria dos elementos repetitivos e de 
elementos parasitas, são hipermetiladas, enquanto outras regiões são hipometiladas (Bird 2002; Suzuki and Bird 2008). Também, existem no genoma seqüências curtas de DNA ricas em CpGs, conhecidas como ilhas $\mathrm{CpG}$, que não exibem metilação e estão geralmente localizadas nos promotores de genes essenciais para a função celular.

As ilhas CpGs são usualmente definidas como uma região com pelo menos 200 pares de bases, cujo conteúdo de guaninas e citosinas é igual ou superior a 50\%, e que apresentam uma razão entre a freqüência observada e a freqüência esperada de dinucleotídeos CpGs igual ou superior a 0,6 (Gardiner-Garden and Frommer 1987). Essas regiões são encontradas em locais próximos aos promotores dos genes de expressão constitutiva e em $40 \%$ das regiões promotoras dos genes de expressão tecidoespecífica (Wang and Leung 2004). A ausência de metilação na região promotora pode ser um pré-requisito para a atividade transcricional desses últimos (Jaenisch and Bird 2003).

O padrão de metilação do DNA muda radicalmente durante o desenvolvimento embrionário. Uma onda de desmetilação generalizada ocorre na fertilização e é seguida por ondas de metilação de novo durante a implantação do embrião. Entretanto, nem todas as seqüências do genoma são desmetiladas no momento da fertilização e também nem todas são metiladas de novo após a implantação. Tais exceções enfatizam a especificidade regional do padrão de metilação do DNA (Reik, Dean et al. 2001). Como evidências da importância de tal padrão podem ser citadas as mutações em genes envolvidos no controle da metilação do DNA que resultam nas síndromes de Rett, do X frágil, da imunodeficiência do tipo ICF (immunodeficiency, centromere instability and facial anomalies) e da alfa talassemia ATRX (alpha-thalassemia/mental retardation) (Robertson and Wolffe 2000; Robertson 2005).

O silenciamento gênico, por meio da metilação do DNA, parece ser um processo regulado por diversos mecanismos. Um desses mecanismos consiste no bloqueio da interação de fatores de transcrição com seus sítios de ligação no DNA. Membros da família das proteínas de ligação a CpGs metilados (do inglês Methyl-CpG binding proteins - MBP), como MeCP2, MBD1-MBD4, induzem o silencimento gênico por se associarem a vários complexos de remodelamento da cromatina e atraírem histonas desacetilases (HDACs), que promovem a compactação da cromatina (Boyes and Bird 1992; Wade 2001). Os dados da literatura sugerem que a ligação do fator CTCF (binding factor-CCCTC) a ilhas $\mathrm{CpG}$ resulta em um efeito protetor contra a metilação e que o fator BORIS (também chamado de CCCTC-binding factor like) 
compete pelos mesmos sítios, deslocando o CTCF e permitindo a atuação de DNMTs e subsequente metilação (Robertson 2005) (Figura 1A).

Recentemente, um grande número de estudos tem mostrado o envolvimento de proteínas do complexo polycomb (PcG; do inglês Polycomb complex group) no estabelecimento de padrões de metilação. As proteínas desse complexo, principalmente PRC1 e PRC2 (Polycomb repressive complex 1 e 2), interagem com DNA metiltransferases e promovem o silenciamento gênico (Vire, Brenner et al. 2006; Jin, Yao et al. 2009; Margueron and Reinberg 2011) (Figura 1A).

\section{MODIFICAÇÃO DE HISTONAS}

Além da metilação do DNA, outro mecanismo epigenético envolve modificações de histonas, principalmente nos resíduos de lisina. Tais modificações incluem acetilação/desacetilação e metilação/desmetilação. As três primeiras são catalisadas enzimaticamente, mas a desmetilação compreende um processo mais complexo. Em geral, a acetilação de histonas está associada com cromatina ativa e a desacetilação com uma estrutura condensada da cromatina (Tyler and Kadonaga 1999; Wade 2001; Jaenisch and Bird 2003) (Figura 2).

A acetilação de resíduos específicos nas histonas H3 e H4 é tipicamente associada com a ativação da transcrição. Por outro lado, a metilação de resíduos específicos nestas histonas promove a ativação ou a repressão da transcrição, dependendo de qual resíduo é modificado e do grau de metilação. Por exemplo, a trimetilação da lisina 4 em histona $\mathrm{H} 3$ (H3K4me3) está associada a regiões de promotores de genes transcricionalmemte ativos enquanto a tri-metilação das lisinas 9 e 27 em histona $\mathrm{H} 3$ (H3K9me3 e H3K27me3) está presente em promotores de genes inativos (Bannister and Kouzarides 2011; Wong, Wong et al. 2011) (Figura 2).

As modificações de histonas mais associadas ao câncer são: a desacetilação de histonas H3 e H4, a perda de trimetilação da lisina 4 da histona H3 (H3K4me3) (Ellinger, Kahl et al. 2010; Benedikt, Baltruschat et al. 2011), a metilação de H3K9 (Chen, Hua et al. 2010) e a trimetilação de H3K27 (Sneeringer, Scott et al. 2010; Testoni, Schinzari et al. 2011). Um fato importante é que estas modificações são acompanhadas de metilação do DNA e, juntas, estas marcas epigenéticas levam a repressão transcricional (Figura 2). 


\section{METILAÇÃO DO DNA E CÂNCER}

A ausência do padrão normal de metilação é um dos achados mais comuns em células transformadas e vários estudos têm revelado que tal alteração é um evento precoce no processo tumorigênico e contribui diretamente para a transformação maligna. Nas células tumorais, a regulação normal da maquinaria de metilação do DNA está severamente comprometida, de tal forma que a especificidade regional dos padrões de metilação é revertido, resultando em metilação de novo das ilhas $\mathrm{CpG} \mathrm{e}$ hipometilação do DNA repetitivo (Jones and Laird 1999; Baylin, Esteller et al. 2001; Robertson 2001; Gaudet, Hodgson et al. 2003; Kaneda, Tsukamoto et al. 2004).

As ilhas $\mathrm{CpG}$ em regiões não promotoras são geralmente mantidas desmetiladas em células normais e são mais sensíveis à metilação que as ilhas em regiões promotoras (Nguyen, Liang et al. 2001). Sua metilação, que não bloqueia a transcrição, é observada tanto em câncer como em tecidos não neoplásicos, embora em alguns tumores sejam marcadores úteis de diagnóstico (Ushijima 2005). Na verdade, esse padrão varia ao longo da ilha CpG. 


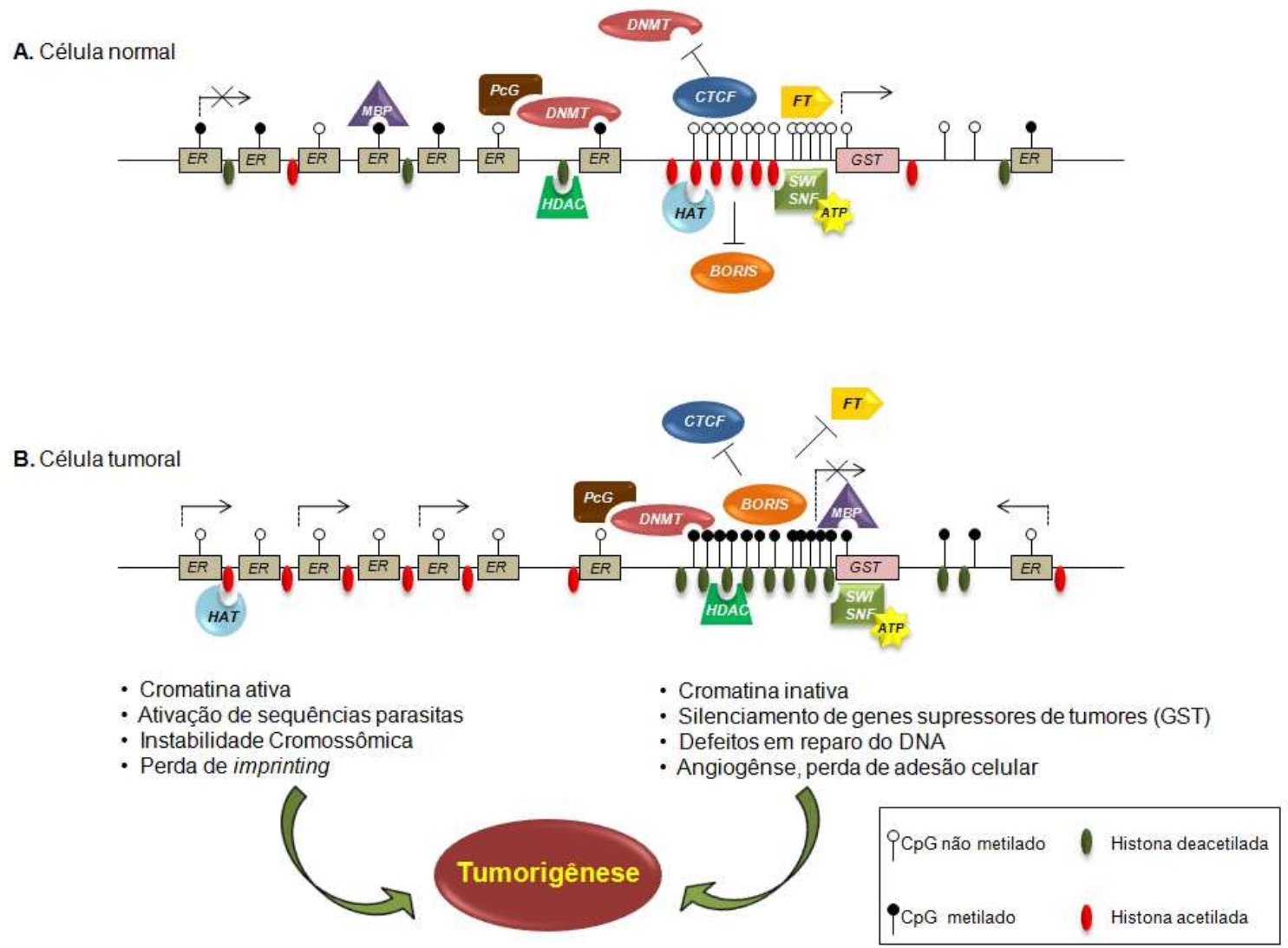

Figura 1. Mecanismos de regulação epigenética na célula normal e no câncer. $O$ diagrama mostra uma região representativa do genoma de uma célula normal (A) e (B) a mesma região em uma célula tumoral. Essa região genômica contém sequências de elementos repetitivos (ER) e de um gene supressor de tumor (GST) com promotor associado a uma ilha CpG. (A) Em células normais, nas regiões de genes supressores de tumor, o DNA é mantido desmetilado e a cromatina contém alta densidade de histonas desacetiladas. Nestas regiões, atuam diversos elementos reguladores da maquinaria epigenética $(\mathrm{CTCF}, \mathrm{HAT})$ que permitem à cromatina ser permissiva aos fatores de transcrição (FT), o que contrasta com as regiões de elementos repetitivos. (B) Em células tumorais, ocorre a alteração desses mecanismos epigenéticos, o que resulta na hipermetilação do DNA e na desacetilação de histonas em regiões de GST, com subsequente ligação de complexos repressivos (BORIS, MBP) a esse DNA metilado impedindo, dessa forma, a transcrição gênica. PcG - complexo repressivo polycomb; MBP - proteína de ligação à metil-CpG; DNMT - DNA metiltransferases; HDAC - histonas desacetilases; HAT histonas acetilases; SWI/SNF - remodelador da cromatina dependente de ATP; FT - fatores de transcrição; GST - gene supressor de tumor; CTCF/BORIS - reguladores de metilação do DNA. Modificado de Esteller, 2007 (Esteller 2007). 


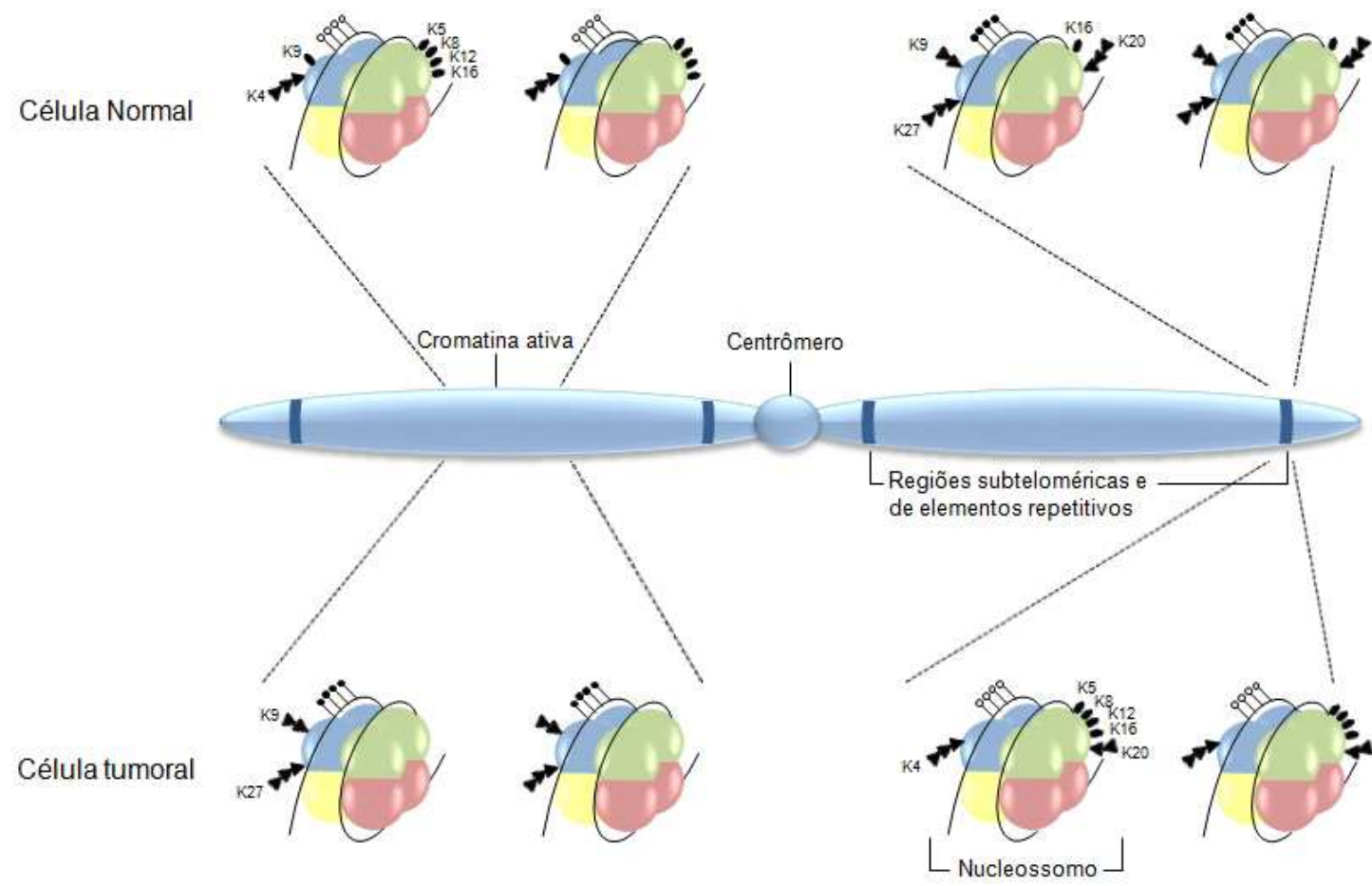

\begin{tabular}{|c|c|c|c|c|}
\hline $\boldsymbol{\Lambda}$ & Metilação em Histona & i CpGNão Metilado & (i) Histona $\mathrm{H} 3$ & Histona $\mathrm{H} 2 \mathrm{~A}$ \\
\hline - & Acetilação em Histona & - CpGMetilado & - Histona $\mathrm{H} 2 \mathrm{~B}$ & Histona H4 \\
\hline
\end{tabular}

Figura 2. Principais modificações no código de histonas em célula normal e no câncer. Os nucleossomos consistem de um octâmero de histonas (H2A, H2B, H3 e H4), representadas como semi-esferas. Em células normais, as regiões genômicas que incluem genes supressores de tumor são ricas em histonas associadas a cromatina transcricionalmente ativa, como a acetilação de resíduos de lisina (K) em histona H3 (K9) e H4 (K5, K8, K12, K16) e a trimetilação de H3K4. Nessas células, regiões de DNA repetitivo ou outras regiões de heterocromatina são caracterizadas pela trimetilação de H3K27, dimetilação de H3K9 e trimetilação de H4K20, que funcionam como marcas repressivas. Em células tumorais, essas marcas são perdidas e frequentemente invertidas. Por exemplo, em regiões de genes supressores de tumor, as histonas perdem as marcas de cromatina ativa e ganham marcas repressoras, como a trimetilação de H3K27 e a dimetilação de H3K9. O contrário ocorre em regiões de DNA repetitivo e de heterocromatina, nas quais a perda de metilação da H3K20 e de trimetilação de H3K27 leva à formação de uma cromatina mais "relaxada" e, consequentemente, ativa. Modificado de Esteller, 2007 (Esteller 2007). 
A metilação consistentemente associada com silenciamento gênico ocorre em um pequeno segmento da região promotora que cobre o sítio de inicio de transcrição (Hagihara, Miyamoto et al. 2004). No entanto, também pode ocorrer fora deste segmento principal mas ainda dentro da ilha, sem bloquear a transcrição, sendo frequentemente observada em câncer e mesmo em células normais (Issa, Ahuja et al. 2001).

A metilação isolada do segmento principal, não associada àquela de regiões flanqueadoras, é rara (Hagihara, Miyamoto et al. 2004). Alguns pesquisadores sugerem que a metilação dessas sequiências flanqueadoras ou de seqüências repetitivas próximas invadem o segmento principal e eventualmente levam à perda de expressão gênica (Jones and Baylin 2002). Outros pesquisadores acreditam que a perda de expressão e a metilação esparsa na ilha CpG são as responsáveis pela indução da metilação densa no segmento principal da ilha (Ushijima 2005). As duas hipóteses não são exclusivas e o padrão de metilação de segmentos flanquadores é potencialmente útil como marcador de risco.

Em diferentes tipos de câncer, já foram identificados muitos genes mostrando alterações epigenéticas. Entre eles estão genes envolvidos na regulação da divisão, da diferenciação e da proliferação celular. Muitos são supressores de tumor cujos promotores apresentam-se metilados nas células tumorais, contudo estão desmetilados nas células normais. Alguns exemplos de genes com padrões epigenéticos aberrantes podem ser citados, como RASSF1, RARB, DAPK1, CDKN2A, CDKN2B, MGMT e GSTP1 em câncer de pulmão, CDKN2A, CALCA, MGMT e TIMP3 em câncer de esôfago, GSTP1 em câncer de próstata e HICl e TP53 em câncer de mama (Esteller and Herman 2002). O gene $C D X 1$, cujo produto está envolvido na regulação do desenvolvimento normal do epitélio intestinal in útero, também exibe correlação positiva entre o estado de metilação de sua região promotora e o padrão de expressão em células de carcinoma colorretal (Wong, Britton et al. 2004). A reativação de muitos desses genes em células tumorais pode levar à supressão do crescimento celular ou à alteração da sensibilidade das células neoplásicas a terapias anticâncer.

Ao contrário do que ocorre com os genes supressores de tumor, os protooncogenes exibem um nível baixo de metilação em células tumorais. Por exemplo, a hipometilação dos genes $R A F 1, M Y C, F O S, H R A S$ e $K R A S$ foi descrita em câncer de fígado, em animais modelo (Verma and Srivastava 2002). Outros exemplos incluem hipometilação do gene $R A S$ em cânceres humanos (Fang, Zhu et al. 1996) e a correlação 
inversa entre metilação e grau de expressão do gene $B C L-2$ em leucemia linfocítica aguda de células B (Hanada, Delia et al. 1993).

A metilação anormal do DNA é um evento epigenético frequente em tumores de cabeça e pescoço (Smiraglia and Plass 2003; Ha and Califano 2006; Worsham, Chen et al. 2006) e representa uma fonte importante de marcadores moleculares. A recorrência de CECP parece ser mais frequente quando há inativação do gene pl6 (CDKN2A) (Kresty, Mallery et al. 2002), enquanto a invasão óssea está associada com metilação do gene $D C C$ (Ogi, Toyota et al. 2002). Entre os genes comumente metilados estão o CDKN2A, o FIHT, o DAPK1, o CDH1, o RASSF1A e o RARB (Rosas, Koch et al. 2001; Hasegawa, Nelson et al. 2002; Kwong, Lo et al. 2002; Ha and Califano 2006; Perez-Ordonez, Beauchemin et al. 2006; Paluszczak, Misiak et al. 2011). Tais resultados abrem a possibilidade de utilização de painéis de genes metilados para o prognóstico desses pacientes.

Realmente, as alterações epigenéticas podem ser empregadas para monitoramento da gênese e da progressão do câncer e constituem alvos terapêuticos potenciais em função de sua reversibilidade. Tratamentos com inibidores de metilação do DNA podem restaurar a atividade de genes silenciados e diminuir a taxa de crescimento de células tumorais em um modo herdável. Por exemplo, a capacidade das células em reparar o DNA danificado pode ser restaurada pela ativação do gene $M L H 1$. A reversão parcial do fenótipo tumoral pelo uso de inibidores de metilação é, portanto, possível \{Costa, 2010 \#163; Datta, 2009 \#164\}.

Recentemente, algumas drogas que revertem a inativação epigenética estão sendo utilizadas em protocolos clínicos para tratamento de pacientes com câncer, como a 5-aza-2'-deoxicitidina (5-Aza-dC). Entretanto, sua alta citotoxicidade, possivelmente decorrente de efeitos não diretamente relacionados com suas atividades desmetilantes, restringe sua aplicação clínica (Silverman, Demakos et al. 2002; Villar-Garea, Fraga et al. 2003). Observações recentes referem que o uso de doses baixas de 5-Aza-dC parece facilitar a reativação de genes metilados. Também têm sido vistas como promissoras sua administração associada a inibidores de desacetilases de histonas (Bryan, Jabbour et al. 2010) e a utilização de oligonucleotídeos antissense para DNA metiltransferases (Winquist, Knox et al. 2006).

Embora os resultados sejam muito interessantes, a relação definitiva entre eficiência clínica e desmetilação de genes-alvo ainda não foi estabelecida. Os dados disponíveis indicam que a cooperação entre diferentes mecanismos de regulação 
epigenética (metilação do DNA, metilação e acetilação de histonas, remodelamento da cromatina) é essencial para o controle apropriado da transcrição gênica. Os diferentes níveis epigenéticos envolvidos nessa complexa cooperação significam que as estratégias de desenvolvimento de drogas devem considerar ambos os eventos, metilação do DNA e modificação das histonas. Realmente, até o presente, inibidores de DNMT, tal como a 5-Aza-dC, são aparentemente os compostos mais ativos para induzir a expressão de genes silenciados epigeneticamente em células tumorais modelos. Entretanto, inibidores das acetilases de histonas podem aumentar os níveis de expressão gênica e existem evidências de que trabalham junto com inibidores de DNMT nesse processo (Bryan, Jabbour et al. 2010).

Os dados acima referidos indicam que o estudo da metilação do DNA e dos elementos da cromatina associados ao silenciamento gênico e à caracterização cuidadosa dos padrões de metilação no câncer humano é muito importante. A precisa quantificação do status de metilação de ilhas $\mathrm{CpG}$ pode, sem dúvida, resultar no desenvolvimento de um marcador molecular poderoso para diagnóstico e prognóstico de neoplasias e levar à identificação de novos alvos terapêuticos. 


\section{OBJETIVOS}

Em função do (a) papel relevante da metilação do DNA na carcinogênese, (b) da importância e da necessidade de identificação de marcadores moleculares precoces em tumores de cabeça e pescoço e (c) dos resultados já obtidos anteriormente pelo nosso grupo, o presente trabalho teve como objetivo geral investigar o perfil de metilação de ilhas CpG em carcinomas epidermóides de cabeça e pescoço (CECP), bem como identificar e iniciar estudos funcionais de biomarcadores candidatos para diagnóstico e prognóstico desses tumores. Os objetivos específicos compreenderam:

1. Analisar, em amostras de carcinomas epidermóides de cabeça e pescoço, o perfil de metilação do DNA na região dos promotores dos genes MX1 e SLC15A3 e correlacionar os resultados obtidos com os dados clínico-patológicos dos pacientes e com a evolução da doença.

2. Analisar, em amostras de carcinomas epidermóides de cabeça e pescoço, o perfil de metilação do DNA em sequência próxima ao sítio de início de transcrição de genes conhecidamente metilados em diversas neoplasias humanas e correlacionar os resultados obtidos com os dados clínico-patológicos dos pacientes e com a evolução da doença.

3. Analisar, em linhagens celulares, o perfil de expressão de dois transcritos variantes do gene $M X 1$ e correlacioná-lo com o padrão de metilação das ilhas CpGs associadas aos seus promotores.

4. Analisar, em linhagens celulares, o perfil de expressão do gene SLC15A3 e correlacioná-lo com o padrão de metilação das ilhas CpGs associadas aos seus promotores.

5. Investigar o efeito do silenciamento da expressão gênica por RNA de interferência contra o $M X 1$ pela análise do índice de proliferação e por estudos de migração e do ciclo celular. 


\section{MATERIAIS E MÉTODOS}

\section{Amostras}

\section{Linhagens celulares de cabeça e pescoço}

No presente trabalho, foram utilizadas linhagens celulares de carcinomas epidermóides de cabeça e pescoço e de outros tipos tumorais, sendo a maioria proveniente da "American Type Culture Collection" (ATCC, Manassas - VA E.U.A.). As características gerais dessas células são mostradas na Tabela 1.

Tabela 1. Características das linhagens utilizadas no estudo.

\begin{tabular}{|c|c|c|c|c|}
\hline \multirow{2}{*}{ Linhagem } & \multirow{2}{*}{ Tecido de origem } & \multirow{2}{*}{ ATCC } & \multicolumn{2}{|c|}{$\begin{array}{l}\text { Dados dos } \\
\text { pacientes }\end{array}$} \\
\hline & & & Idade & Sexo \\
\hline$S C C-4$ & Carcinoma epidermóide de língua & CRL-1624 & 55 & homem \\
\hline$S C C-9$ & Carcinoma epidermóide de língua & CRL-1629 & 25 & homem \\
\hline$S C C-15$ & Carcinoma epidermóide de língua & CRL-1623 & 55 & homem \\
\hline$S C C-25$ & Carcinoma epidermóide de língua & CRL-1628 & 70 & homem \\
\hline$S C C-38$ & Carcinoma epidermóide de laringe & ND & 66 & homem \\
\hline$F a D u$ & Carcinoma epidermóide de hipofaringe & HTB-43 & 56 & homem \\
\hline$T A L L$ & Leucemia linfoblástica aguda & CRL-11386 & 2 & homem \\
\hline LOUCY & Leucemia linfoblástica aguda de células $\mathrm{T}$ & CRL-2629 & 38 & mulher \\
\hline WDT4 & Leucemia linfocítica aguda $(B C R / A B L+)$ & ND & ND & ND \\
\hline WDT5 & Leucemia linfocítica aguda $(B C R / A B L+)$ & ND & ND & ND \\
\hline HL60 & Leucemia promielocitica aguda & CCL-240 & 36 & mulher \\
\hline CEM & Leucemia linfoblástica aguda & CRL-2264 & 4 & mulher \\
\hline$B V-173$ & Leucemia aguda $(\mathrm{Ph}+)$ & ND & 46 & homem \\
\hline$R S 4$ & Leucemia linfoblástica aguda & CRL-1873 & 32 & mulher \\
\hline MCF12 & Epitélio de mama & CRL-10782 & 60 & mulher \\
\hline CAMA1 & Adenocarcinoma de mama & HTB-21 & 51 & mulher \\
\hline MCF7 & Adenocarcinoma de mama & HTB-22 & 69 & mulher \\
\hline$M B-468$ & Adenocarcinoma de mama & HTB-132 & 51 & mulher \\
\hline SKBR3 & Adenocarcinoma de mama & HTB-30 & 43 & mulher \\
\hline HCT116 & Carcinoma colorretal & CCL-247 & adulto & homem \\
\hline SW620 & Adenocarcinoma colorretal & CCL-227 & 51 & homem \\
\hline$S W 480$ & Adenocarcinoma colorretal & CCL-228 & 50 & homem \\
\hline KM12 & Adenocarcinoma colorretal & $\mathrm{ND}$ & ND & $\mathrm{ND}$ \\
\hline H460 & Carcinoma de pulmão & HTB-177 & ND & homem \\
\hline
\end{tabular}

ND - não determinado. 


\section{Amostras de doadores normais (sangue)}

Como controle, foram utilizadas sete amostras de sangue periférico de doadores normais, gentilmente cedidos pela prof.a. Fernanda Carregaro.

\section{Amostras de carcinomas epidermóides de cabeça e pescoço}

No presente estudo, também foram utilizadas amostras de tumores e margens cirúrgicas provenientes de 54 pacientes com carcinoma epidermóide das vias aerodigestivas superiores. Na Tabela 2, estão apresentados os dados clínico-patológicos de cada paciente. Tais amostras foram colhidas após ressecção cirúrgica pelas equipes de médicos do Projeto Temático (Processo FAPESP 04/12054-9) "Marcadores de agressividade em tumores de cabeça e pescoço" (Instituto Arnaldo Vieira de Carvalho, SP; Hospital Heliópolis; Hospital das Clínicas da Faculdade de Medicina, USP, SP; UNIVAP, São José dos Campos) e imediatamente armazenadas em nitrogênio líquido ou freezer $-80^{\circ} \mathrm{C}$, para posterior microdissecção, extração de RNA, DNA e proteínas. De todos os pacientes foram obtidas informações clínicas e laboratoriais. O projeto temático foi aprovado pelo CONEP (Parecer 1763/05 - Proc. 25000.152864/2005-50, Registro no. 12380/CONEP, Data 18/095/2005). 
Tabela 2 - Característica clínico patológicas das amostras de carcinomas epidermóides de cabeça e pescoço

\begin{tabular}{|c|c|c|c|c|c|c|c|c|c|c|c|c|c|}
\hline Caso & Sexo & Idade & Fuma & Etilista & Sítio & TNM & Estadio & $\begin{array}{l}\text { Diferenciação } \\
\text { Histológica }\end{array}$ & $\begin{array}{l}\text { Infilitração } \\
\text { Vascular } \\
\text { Sanguínea }\end{array}$ & $\begin{array}{c}\text { Infilttração } \\
\text { Linfática }\end{array}$ & $\begin{array}{c}\text { Invasão } \\
\text { Perineural }\end{array}$ & $\begin{array}{c}\text { Infiltrado } \\
\text { Inflamatório } \\
\text { peri-tumoral }\end{array}$ & Óbito \\
\hline CP1/0012 & $\mathrm{M}$ & 55 & Sim & Sim & Faringe & T4N2BM0 & IV & Moderadamente & Ausente & Presente & Ausente & Escasso & Pela Neoplasia \\
\hline CP1/0019 & $\mathrm{F}$ & 59 & No passado & No passado & Língua & T4N2CM0 & IV & Bem diferenciado & Ausente & Presente & Presente & Moderado & Pela Neoplasia \\
\hline CP1/0174 & M & 68 & Sim & No passado & Laringe & T2N0M0 & II & Bem diferenciado & Ausente & Ausente & Ausente & Intenso & Não \\
\hline CP1/0271 & $\mathrm{F}$ & 50 & $\operatorname{Sim}$ & Nunca & Laringe & T2N1M0 & III & Pouco diferenciado & Ausente & Ausente & Ausente & Moderado & Não \\
\hline СР3/0018 & M & 61 & Sim & No passado & Laringe & T4N2BM0 & IV & Moderadamente & Ausente & Ausente & Ausente & Moderado & Pela Neoplasia \\
\hline СР3/0019 & $\mathrm{M}$ & 54 & Sim & Sim & Laringe & T4N0M0 & IV & Moderadamente & Ausente & Ausente & Ausente & Escasso & Não \\
\hline СР3/0020 & M & 53 & No passado & No passado & Laringe & T1N1M0 & III & Moderadamente & Ausente & Ausente & Presente & Moderado & Não \\
\hline СР3/0031 & M & 54 & Sim & Sim & Laringe & T4N2CM0 & IV & Moderadamente & Ausente & Ausente & Presente & Moderado & Pela Neoplasia \\
\hline СР3/0069 & M & 58 & Sim & Sim & Língua & T1N0M0 & I & Pouco diferenciado & Ausente & Ausente & Ausente & Moderado & Não \\
\hline СР3/0076 & M & 64 & No passado & No passado & Laringe & T4N2BM0 & IV & Pouco diferenciado & Ausente & Ausente & Presente & Escasso & Não \\
\hline СР3/0084 & $\mathrm{M}$ & 61 & Sim & Nunca & Laringe & T3NOM0 & III & Bem diferenciado & Ausente & Ausente & Ausente & Moderado & Não \\
\hline СР3/0085 & M & 59 & Sim & Sim & Laringe & T4N3M0 & IV & Pouco diferenciado & Ausente & Ausente & Ausente & Moderado & Não \\
\hline СР3/0096 & M & 54 & Sim & Nunca & Laringe & T4N0M0 & IV & ND & Ausente & Ausente & Ausente & Escasso & Não \\
\hline СР3/0102 & M & 49 & Sim & Sim & Laringe & T2N1M0 & III & Bem diferenciado & Presente & Ausente & Ausente & Escasso & Não \\
\hline СР3/0105 & M & 67 & No passado & Sim & Laringe & T4N2CM0 & IV & Moderadamente & Ausente & Ausente & Presente & Moderado & Pela Neoplasia \\
\hline СР3/0113 & M & 67 & Nunca & Sim & Língua & T4N1M0 & IV & Bem diferenciado & Ausente & Ausente & Ausente & Moderado & Não \\
\hline СР3/0119 & M & 67 & Sim & Sim & Laringe & T4N2CM0 & IV & Bem diferenciado & Ausente & Presente & Presente & ND & Pela Neoplasia \\
\hline СР3/0124 & M & 68 & Sim & Sim & Laringe & T4N2CM0 & IV & Moderadamente & Ausente & Ausente & ND & Escasso & Pela Neoplasia \\
\hline СР3/0125 & M & 63 & No passado & No passado & Laringe & T4N3M0 & IV & Pouco diferenciado & Presente & Presente & Presente & Moderado & Não \\
\hline CP3/0136 & M & 65 & Sim & Sim & Laringe & T4N2BM0 & IV & Bem diferenciado & Ausente & Ausente & Ausente & Escasso & Pela Neoplasia \\
\hline CP3/0147 & M & 44 & No passado & Nunca & Laringe & T2NOM0 & II & Moderadamente & Ausente & Ausente & Ausente & ND & Não \\
\hline CP3/0153 & M & 49 & Sim & No passado & Laringe & T3N3M0 & IV & Moderadamente & Presente & Presente & Presente & Moderado & Pela Neoplasia \\
\hline СР3/0193 & M & 49 & No passado & No passado & Língua & T2N1M0 & III & Bem diferenciado & Ausente & Ausente & Ausente & ND & Não \\
\hline СР3/0199 & M & 74 & Sim & Nunca & Laringe & T4N0M0 & IV & Bem diferenciado & Ausente & Ausente & Ausente & Moderado & Não \\
\hline СР3/0209 & M & 67 & No passado & No passado & Laringe & T4N0M0 & IV & Bem diferenciado & Ausente & Ausente & Presente & Escasso & Pela Neoplasia \\
\hline СР $3 / 0246$ & M & 69 & No passado & Nunca & Laringe & T4NOM-ND & ND & Moderadamente & Ausente & Ausente & Presente & Escasso & Não \\
\hline СР3/0377 & M & 78 & No passado & No passado & Laringe & T4NOM-ND & ND & Moderadamente & Ausente & Ausente & Presente & ND & Outras Causas \\
\hline СР3/0390 & M & 55 & Sim & Sim & Laringe & T4N0M-ND & ND & Moderadamente & Ausente & Ausente & Ausente & Intenso & Não \\
\hline СР3/0411 & M & 49 & Sim & Sim & Laringe & T4N2BM-ND & ND & Moderadamente & Presente & Ausente & Presente & Intenso & Outras Causas \\
\hline СР3/0433 & M & 56 & Sim & Sim & Laringe & T4NOM-ND & ND & Bem Diferenciado & Ausente & ND & Ausente & Escasso & Não \\
\hline CP3/0464 & M & 79 & Sim & No passado & Laringe & T4N2BM-ND & ND & Moderadamente & Ausente & Ausente & Ausente & Intenso & Pela Neoplasia \\
\hline СР3/0485 & M & 47 & Sim & No passado & Laringe & T3NOM-ND & ND & Moderadamente & Ausente & Ausente & Ausente & ND & $\mathrm{ND}$ \\
\hline CP4/0002 & M & 56 & Sim & Sim & Laringe & T3NOM-ND & ND & Bem Diferenciado & Ausente & Ausente & Ausente & Moderado & Não \\
\hline CP4/0008 & M & 46 & Sim & Sim & Laringe & T3NOM-ND & ND & Moderadamente & Ausente & Ausente & Ausente & Intenso & Não \\
\hline
\end{tabular}




\begin{tabular}{|c|c|c|c|c|c|c|c|c|c|c|c|c|c|}
\hline СР $4 / 0016$ & $\mathrm{~F}$ & 52 & Sim & Sim & Laringe & T1NOM-ND & ND & Bem diferenciado & Ausente & Ausente & Ausente & Escasso & Não \\
\hline CP $4 / 0024$ & M & 45 & Sim & No passado & Laringe & T4NOM-ND & ND & Bem diferenciado & Ausente & Ausente & Ausente & Intenso & ND \\
\hline 271901 & M & 56 & Sim & Sim & Faringe & ND & ND & ND & ND & ND & ND & ND & ND \\
\hline 275296 & M & 50 & No passado & Nunca & Laringe & ND & ND & ND & ND & ND & ND & ND & ND \\
\hline 279422 & $\mathrm{~F}$ & 58 & Sim & Sim & Laringe & ND & ND & ND & ND & ND & ND & ND & ND \\
\hline 281415 & M & 50 & Sim & Sim & Laringe & T4N1M0 & ND & ND & ND & ND & ND & ND & ND \\
\hline СР1/0001 & M & 53 & Sim & Sim & Laringe & $\mathrm{T} 2 \mathrm{~N} 2 \mathrm{M} 0$ & IV & Moderadamente & Presente & Presente & Presente & Moderado & Pela neoplasia \\
\hline CP1/0006 & M & 57 & Sim & Sim & Laringe & T4N1M0 & IV & Moderadamente & Ausente & Presente & Presente & Escasso & Pela neoplasia \\
\hline CP1/0017 & M & 55 & Sim & No passado & Língua & T2N0M0 & II & Moderadamente & Ausente & Ausente & Ausente & Moderado & Não \\
\hline CP1/0027 & M & 48 & Sim & Sim & Laringe & T4N2CM0 & IV & Bem diferenciado & Ausente & Presente & Ausente & Escasso & Pela neoplasia \\
\hline CP1/0023 & M & 56 & Sim & Sim & Faringe & T4N0M0 & IV & Moderadamente & Ausente & Ausente & Ausente & Moderado & Pela neoplasia \\
\hline CP1/0042 & M & 70 & Sim & Sim & Laringe & T4N2CM0 & IV & Moderadamente & Ausente & Presente & Ausente & Escasso & Pela neoplasia \\
\hline CP $1 / 0036$ & M & 66 & No passado & No passado & Laringe & T4N0M0 & IV & Moderadamente & Ausente & Ausente & Presente & Escasso & Pela neoplasia \\
\hline CP1/0037 & M & 55 & Sim & No passado & Faringe & T4N2BM0 & IV & Moderadamente & Presente & Presente & Presente & Moderado & Pela neoplasia \\
\hline СР1/0041 & M & 44 & Sim & No passado & Faringe & T4N2BM0 & IV & Moderadamente & Ausente & Presente & Ausente & Moderado & Não \\
\hline CP1/0046 & M & 60 & No passado & Sim & Laringe & T4N2CM0 & IV & Moderadamente & Ausente & Presente & Presente & Escasso & Outra causa \\
\hline CP1/0058 & M & 50 & Sim & No passado & Laringe & T4N2CM0 & IV & Moderadamente & Presente & Presente & Ausente & Moderado & Não \\
\hline СР1/0049 & M & 44 & Sim & No passado & Língua & T4N2CM0 & IV & Moderadamente & Presente & Presente & Presente & Moderado & Não \\
\hline CP1/0066 & M & 72 & Sim & Sim & Laringe & T4N2BM0 & IV & Bem diferenciado & Ausente & Presente & Ausente & Moderado & Pela neoplasia \\
\hline CP1/0065 & $\mathrm{M}$ & 46 & Sim & No passado & Faringe & T2NOM0 & II & Bem diferenciado & Ausente & Ausente & Ausente & Moderado & Não \\
\hline
\end{tabular}

ND - Não determinado 


\section{Extração de DNA}

O DNA das amostras de carcinomas epidermóides de cabeça e pescoço foi obtido pelo método de extração por TRIzol $^{\circledR}$ de RNA, DNA e proteínas (Invitrogen, Carlsbad - CA, E.U.A) seguindo protocolo fornecido pelo fabricante. Os DNAs das linhagens celulares utilizadas no presente trabalho foram gentilmente cedidos pelo Dr. Jean-Pierre Issa, MD Anderson Cancer Center, Houston, Texas.

\section{Conversão do DNA por Bisssulfito de Sódio}

Após a determinação da concentração por espectrofotometria, $2 \mu \mathrm{g}$ de DNA genômico foi ressuspendido em $20 \mu \mathrm{l}$ de DDW (Double Destilled Water). Em seguida, os DNAs foram tratados com bissulfito de sódio, que promove a desaminação de citosinas não metiladas em uracilas, posteriormente substituídas por timinas durante a síntese de uma nova fita de DNA. As citosinas metiladas (5-metilcitosinas), ao contrário, são mantidas intactas e permanecem como citosinas após a reação de amplificação. A reação foi realizada com a utilização do EZ DNA Methylation Gold $K_{i t}{ }^{\mathrm{TM}}$ (Zymo, Irvine - CA, E.U.A) de acordo com as instruções fornecidas pelo fabricante.

\section{Desenho de iniciadores para Nested PCR e Pirosequenciamento}

As regiões promotoras dos genes SLC15A3, MX1,CDH1, CDH13, DAPK, CDKN2A, RASSF1A, SOCS3, TIMP3 foram amplificadas por PCR Nested e posteriormente sequenciadas. Foram desenhados, com o auxílio do programa PyroMark Assay Design Software (Qiagen, Valencia - CA, E.U.A.), iniciadores externos e internos aos CpGs presentes nas regiões promotoras de cada gene, além de uma sonda de sequenciamento. Uma sequência universal de nucleotídeos (5' GGGACACCGCTGATCGTTTA - 3'), necessária para a ligação da biotina, foi adicionada a um dos iniciadores utilizados nas reações de nested PCR. Após amplificação dos fragmentos de interesse, a fita do DNA biotinilada foi purificada e, posteriormente, a porcentagem de metilação dessas regiões foi avaliada por pirosequenciamento. A Tabela 3 mostra a seqüência dos iniciadores externos, dos iniciadores internos e da sonda de sequenciamento de cada gene, bem como os tamanhos dos produtos de amplificação. 


\section{PCR e Nested PCR}

As reações da primeira PCR e da Nested PCR foram processadas em $25 \mu \mathrm{L}$, contendo 2,5 $\mu \mathrm{l}$ de tampão 10X, 4,0 $\mu \mathrm{l}$ de dNTP mix a 1,25 $\mu \mathrm{M}), 1 \mu \mathrm{lde} \mathrm{MgCl}^{2+}$ a $50 \mathrm{mM}, 0,4 \mu \mathrm{l}$ de oligonucleotídeos a 10 pmol e $0,2 \mu \mathrm{l}$ de polimerase de DNA a $5 \mathrm{U} / \mu \mathrm{l}$. Em todos os experimentos, um dos tubos não recebeu DNA, como controle de contaminação. Para a primeira PCR, foram utilizados cerca de 50 ng de DNA tratado e $1 \mu \mathrm{l}$ desse produto foi utilizado para a Nested PCR.

A reação da primeira PCR compreendeu um passo inicial de 10 minutos a $95^{\circ} \mathrm{C}$ para ativação da enzima Taq Platinum (Invitrogen), seguido de 30 ciclos de: 50 segundos a $95^{\circ} \mathrm{C}, 50$ segundos à temperatura de anelamento de cada seqüência, 1 minuto a $72^{\circ} \mathrm{C}$ e um passo final de cinco minutos a $72^{\circ} \mathrm{C}$ para extensão dos fragmentos. 
Tabela 3 - Iniciadores externos, iniciadores internos e sonda de sequenciamento de cada gene de interesse, bem como os tamanhos dos respectivos produtos de amplificação.

\begin{tabular}{|c|c|c|c|}
\hline Gene & Localização & Oligo & $5^{\prime} \rightarrow 3^{\prime}$ \\
\hline \multirow{5}{*}{$\begin{array}{c}\boldsymbol{M X 1} \\
\text { (Variante longa) }\end{array}$} & \multirow{5}{*}{$+289 /+317$} & F1 & TAGGGAGGATGGGTAGGTTGT \\
\hline & & R1 & САССАССAАAAAACAATATTACTC \\
\hline & & $\mathrm{F} 2$ & GATGGGTAGGTTGTGGGATGT \\
\hline & & RU & GGGACACCGCTGATCGTTTACACCACCAAAAAACAATATTACTC \\
\hline & & $\mathrm{S}$ & GTAGGTTGTGGGATGTT \\
\hline \multirow{10}{*}{$\begin{array}{c}\text { MXI } \\
\text { (Variante curta) }\end{array}$} & \multirow{5}{*}{$\begin{array}{c}+53 /+97 \\
\text { (região 1) }\end{array}$} & F1 & GAAGGGGGGAAGGATATGTTTA \\
\hline & & $\mathrm{R} 1$ & ССССААСССАААССТАСТАААТС \\
\hline & & $\mathrm{F} 2$ & GGGGGAAGGATATGTTTAGGTT \\
\hline & & RU & GGGACACCGCTGATCGTTTACCCCAACCCAAACCTACTAAATC \\
\hline & & $\mathrm{S}$ & GGATATGTTTAGGTTTAAGG \\
\hline & \multirow{5}{*}{$\begin{array}{c}+668 /+709 \\
\text { (região 2) }\end{array}$} & F1 & TTAGAGGTTTTTTTGTAGGAGAGG \\
\hline & & $\mathrm{R} 1$ & AAAAATCCACCAAAAACAATAATC \\
\hline & & $\mathrm{F} 2$ & TTTTTTGTAGGAGAGGTTGGGAAG \\
\hline & & RU & GGGACACCGCTGATCGTTTAAAAAATCCACCAAAAACAATAATC \\
\hline & & $\mathrm{S}$ & TGGGAAGGGGTGGGG \\
\hline \multirow{5}{*}{$S L C 15 A 3$} & \multirow{5}{*}{$+369 /+403$} & F1 & TTGTTGGTGGAGATGTTGGA \\
\hline & & $\mathrm{R} 1$ & СТАСТСССССАТССААТТАААА \\
\hline & & FU & GGGACACCGCTGATCGTTTATTGTTGGTGGAGATGTTGGA \\
\hline & & $\mathrm{R} 2$ & CCCATCCAATTAAAATTAATAC \\
\hline & & $\mathrm{S}$ & AAAATTAATACTATTAAAATACAA \\
\hline \multirow{5}{*}{$\mathrm{CDH1}$} & \multirow{5}{*}{$-33 /+2$} & F1 & TTAGGAGAGAGGAAGGGATTGG \\
\hline & & $\mathrm{R} 1$ & ССССАТтТСТСАТТССТАССА \\
\hline & & $\mathrm{F} 2$ & тTTATTTGGGGTTTTTGAGGGT \\
\hline & & RU & GGGACACCGCTGATCGTTTACCCCAтTTCTCATTCCTACCA \\
\hline & & $\mathrm{S}$ & TTTTAGTTTAGGTTTTATTTATAAG \\
\hline \multirow{5}{*}{$\mathrm{CDH13}$} & \multirow{5}{*}{$+74 /+102$} & F1 & TTTGGGAAGTTGGTTGGTTG \\
\hline & & $\mathrm{R} 1$ & AСААССССТСТTСССТАCсt \\
\hline & & $\mathrm{F} 2$ & AgTTTGGTTTTTAAGGAAAATATGTTTAGT \\
\hline & & RU & GGGACACCGCTGATCGTTTAACCAAATTCTCCACTACATTTTATCC \\
\hline & & $\mathrm{S}$ & TAAGGAAAATATGTTTAGTGTA \\
\hline \multirow{5}{*}{ RASSF1A } & \multirow{5}{*}{$+213 /+244$} & F1 & ATGTAGGGGGAGTTTGAGTTTATTGA \\
\hline & & $\mathrm{R} 1$ & CACCACCCCCCAAATAAAATC \\
\hline & & $\mathrm{F} 2$ & GTTGGGAGAGTTGGGAAGGGT \\
\hline & & RU & GGGACACCGCTGATCGTTTACACCACCCCCCAAATAAAATC \\
\hline & & $\mathrm{S}$ & AGGGTYGTATTYGGTTGGA \\
\hline \multirow{5}{*}{ DAPK1 } & \multirow{5}{*}{$-24 /+10$} & $\mathrm{~F} 1$ & AGAGAGGAGTTGGGAGGAGTAG \\
\hline & & $\mathrm{R} 1$ & СССАСАААССАССААТАААAАС \\
\hline & & $\mathrm{F} 2$ & GTAGAGTAGGTTTGGTAGGGTAGTT \\
\hline & & RU & GGGACACCGCTGATCGTTTACCCACAAACCACCAATAAAAAC \\
\hline & & $\mathrm{S}$ & GTAGGGTAGTTYGGAGGTG \\
\hline \multirow{5}{*}{$C D K N 2 A$} & \multirow{5}{*}{$-16 /+25$} & F1 & GGGGTAGGTGGGGAGGAGTT \\
\hline & & $\mathrm{R} 1$ & ссСстсстстттсттсстсС \\
\hline & & F2 & GGTTGTTTTAGGTTGGTGTTTT \\
\hline & & $* \mathrm{R}$ & *-АСССТАТСССТСАААТССТСТАAАA \\
\hline & & $\mathrm{S}$ & GATTTTAGGGGTGTTATATT \\
\hline \multirow{5}{*}{ SOCS3 } & \multirow{5}{*}{$-3 /+39$} & F1 & GGAGGGGATTAGGAGAGGGAT \\
\hline & & $\mathrm{R} 1$ & ACCCCCCAATTCCAAAAATC \\
\hline & & $\mathrm{F} 2$ & GAAGAGGTAGTAGAGGAGTAGGGAGTTTA \\
\hline & & RU & GGGACACCGCTGATCGTTTACCCCCCAATTCCAAAAATC \\
\hline & & $\mathrm{S}$ & AGAGGAGTAGGGAGTTTAAG \\
\hline & & $\mathrm{F} 1$ & GGTGGGTGGGTGTTAGTTGG \\
\hline & & $\mathrm{R} 1$ & САААСССТССТАССССТТСТС \\
\hline TIMP3 & $+538 /+619$ & $\mathrm{~F} 2$ & GGTTTTGGTTTGGGTTAGAGATA \\
\hline & & RU & GGGACACCGCTGATCGTTTACAAACCCTCCTACCCCTTCTC \\
\hline & & $\mathrm{S}$ & GGTTAGAGATATTTAGTGGTTTA \\
\hline
\end{tabular}


A reação de Nested PCR compreendeu um passo inicial de 10 minutos a $95^{\circ} \mathrm{C}$ para ativação da enzima Taq Platinum, seguido de 5 ciclos de: 50 segundos a $95^{\circ} \mathrm{C}, 50$ segundos à temperatura de anelamento de cada gene, 1 minuto a $72^{\circ} \mathrm{C}$ e um passo final de cinco minutos a $72^{\circ} \mathrm{C}$ para extensão dos fragmentos. Os produtos das amplificações foram submetidos à corrida eletroforética em gel de poliacrilamida $8 \%$ para visualização das bandas de interesse.

\section{Pirosequenciamento}

A metodologia de pirosequenciamento foi realizada neste trabalho por possibilitar a análise quantitativa de metilação do DNA em regiões promotoras dos genes de interesse. Essa técnica necessita que o produto de PCR esteja na forma de fita simples de DNA, o que permite à sonda de sequenciamento anelar-se à sequencia alvo. Diversos métodos têm sido descritos e mostraram-se eficientes na obtenção da fita molde de DNA para as reações de pirosequenciamento (Nordstrom, Nourizad et al. 2000; Nordstrom, Alderborn et al. 2002; Diggle and Clarke 2003). No presente trabalho, foi utilizado o método descrito por Ronaghy e colaboradores, 1996 (Ronaghi, Karamohamed et al. 1996), que produz um DNA de alta qualidade sem a necessidade de purificação prévia do produto de PCR. Nessa técnica, uma das fitas do produto de PCR é marcada com biotina. Essa fita é capturada em microesferas revestidas por estreptoavidina e o DNA não biotinilado é removido por tratamento com solução alcalina ( $\mathrm{NaOH}$ 0,2M). O DNA biotinilado é então lavado com uma solução de Tris $(10 \mathrm{mM}, \mathrm{pH} 7,6)$ para neutralizar o $\mathrm{pH}$ básico. Finalmente, a fita simples de DNA purificada é transferida para uma placa de pirosequencimento contendo um tampão de anelamento (20mM Tris acetato, $2 \mathrm{mM} \mathrm{Mg}$ acetato, $\mathrm{pH} 7,6)$ e a sonda de sequenciamento.

Estes últimos experimentos foram desenvolvidos no laboratório do Dr. JeanPierre Issa do departamento de Leucemia, MD Anderson Cancer Center, Universidade do Texas, Houston-TX.

\section{Cultivo Celular}

Os experimentos seguintes foram realizados no laboratório do Roger Chammas do departamento de Oncologia, Faculdade de Medicina, Universidade de São Paulo FMUSP. 
As linhagens celulares de carcinoma epidermóide de cabeça e pescoço ( $S C C-4$, $S C C-9, S C C$-15 e $S C C-25$ ) foram cultivadas em frascos plásticos de 25 ou $75 \mathrm{~cm}^{2} \mathrm{em}$ meio de cultura DMEM/F-12 (Invitrogen), suplementado com 10\% de soro fetal bovino (SFB), penicilina $(100 \mathrm{U} / \mathrm{mL})$, estreptomicina $(100 \mu \mathrm{g} / \mathrm{mL})$, glutamina $(4 \mathrm{mM})$, a $37^{\circ} \mathrm{C}$ em atmosfera contendo $5 \%$ de $\mathrm{CO} 2$ e $95 \%$ de umidade. As células utilizadas nos experimentos foram subcultivadas sempre que atingiram uma confluência de aproximadamente 60-70\%. Para isto, o meio de cultura foi removido, as células lavadas com $10 \mathrm{ml}$ de solução salina tamponada com fosfato pH 7,4 (PBS) e então incubadas a $37^{\circ} \mathrm{C}$ com $0,5 \mathrm{ml}$ ou $2 \mathrm{ml}$ de tripsina a $2 \%$, para frascos de $25 \mathrm{~cm}^{2}$ ou $75 \mathrm{~cm}^{2}$, respectivamente. Após um período que variou de 5 a 25 minutos, dependendo da linhagem, as células destacaram-se do soalho do frasco de cultura (o que foi determinado por observação em microscópio de contraste de fase), sendo então a ação da tripsina interrompida pela adição de meio de cultura DMEM (Invitrogen) com 10\% de SFB. A suspensão de células foi transferida para tubos falcon de $15 \mathrm{ml}$ estéreis e centrifugada a $1500 \mathrm{rpm}$ por 5 minutos. O sobrenadante foi removido e descartado e o pellet de células ressuspendido em $5 \mathrm{ml}$ de meio de cultura DMEM/F-12 com 10\% de $\mathrm{SFB}$, as células contadas e replaqueadas em novos frascos de $25 \mathrm{~cm}^{2}$ ou $75 \mathrm{~cm}^{2}\left(1 \mathrm{x} 10^{3}\right.$ células em $5 \mathrm{ml}$ de meio para frascos de $25 \mathrm{~cm}^{2}$ e $1 \times 10^{5}$ células em $10 \mathrm{ml}$ de meio para frascos de $75 \mathrm{~cm}^{2}$ ). O meio de cultura foi trocado a cada 48 horas. Com o objetivo de manter o estoque congelado em nitrogênio líquido e trabalhar sempre com as células em passagens semelhantes, várias amostras de cada linhagem celular foram congeladas antes da realização dos experimentos. Para isto, as células foram suspensas em solução 1/1 de DMEM/F-12 contendo 20\% de di-metilsulfóxido (DMSO - Sigma, Munich, Alemanha) e DMEM/F-12 com 50\% de SFB e congeladas em nitrogênio líquido.

\section{Curvas de proliferação celular}

O potencial proliferativo das linhagens SCC foi avaliado por curvas de proliferação. Um total de $5 \times 10^{3}$ células foi plaqueado em $1 \mathrm{ml}$ de meio DMEM/F12 contendo $10 \%$ de SFB em cada poço de uma placa para cultura celular de 24 poços (Nunc Brand Products, Roskilde, Dinamarca). Após 24 horas, o meio foi trocado por DMEM/F-12 livre de SFB e as células incubadas por mais 48 horas. Para estimular o crescimento celular, o meio foi substituído por DMEM/F-12 contendo $10 \%$ de FBS. Após 24, 48, 72, 96, 120, 144, 168 e 192 horas, as células de 2 poços de cada placa foram lavadas duas vezes com PBS a $37{ }^{\circ} \mathrm{C}$ e incubadas com $0,3 \mathrm{ml}$ de tripsina a $2 \%$, 
também a $37^{\circ} \mathrm{C}$ por $20-25$ minutos, até que estivessem completamente separadas do soalho da placa. A tripsina foi inativada com $2 \mathrm{ml}$ de meio DMEM com 10\% de FBS. O crescimento e a morfologia celular foram avaliados diariamente em microscópio invertido.

\section{Silenciamento de expressão gênica por RNA de interferência}

O silenciamento da expressão do gene $M X 1$ foi realizados nas linhagens $S C C$ 4, SCC-9, SCC-15 e SCC-25. Para tanto, foi utilizado o kit TriFECTa (Integrated DNA Technologies - Coralville, IA, E.U.A.) que contém três oligos duplex de 27mer, específicos para o gene $M X 1$, e um controle negativo (duplex Scrambled universal).

Para cada experimento, foi feito o plaqueamento de $2 \times 10^{4}$ células em placa de 24 poços. As células foram cultivadas até atingirem entre 40 e $60 \%$ de confluência e, 24 horas antes da realização dos experimentos de transfecção, o meio foi substituído por outro sem antibiótico. No momento da transfecção, o meio foi removido e as células lavadas com PBS e a transfecção foi realizada com meio Opti-MEM (Invitrogen). Durante a etapa de padronização, as células foram transfectadas com $1 \mathrm{nM}, 10 \mathrm{nM}$ e 20nM de duplex para $M X 1$ e 10nM para os controles, e os lipossomos foram utilizados como agentes de transfecção. Foram testados dois tipos de lipossomos; a Lipofectamine 2000 (Invitrogen) e a Lipofectamine RNAiMax (Invitrogen). As células foram mantidas em incubadora úmida a $37^{\circ} \mathrm{C}$ em atmosfera de $5 \%$ de $\mathrm{CO}_{2}$. Após um período de 24 horas, os RNAs das linhagens celulares foram extraídos, os cDNAs foram confeccionados e foram realizadas reações de PCR em tempo real para avaliação do nível de expressão do gene $M X 1$.

\section{Extração de RNA e síntese de cDNA}

O RNA total das amostras foi isolado com TRIzol ${ }^{\circledR}$ (Invitrogen) e sua qualidade e integridade foram avaliadas por espectrometria e eletroforese em gel de agarose. Depois de isolados, os RNAs foram utilizados para síntese de DNA complementar (cDNA) com a enzima transcriptase reversa e posterior amplificação e quantificação por PCR em tempo real.

O RNA total foi previamente tratado com RQ1 Rnase-Free Dnase (Promega Corporation, Madison - WI. E.U.A.), seguindo especificações do fornecedor, a fim de eliminar qualquer vestígio de DNA genômico. A síntese de cDNA foi realizada com o High Capacity cDNA Archive Kit (Applied Biosystems, Carlsbad - CA, E.U.A.), 
segundo protocolo do fornecedor. A qualidade da síntese foi avaliada por reação de RTPCR para o gene GAPDH.

\section{PCR em tempo real}

A metodologia de PCR em tempo real foi realizada segundo protocolo estabelecido no laboratório. Todas as reações de PCR em tempo real foram realizadas no aparelho 7500 Real-Time PCR System (Applied Biosystems). Foram desenhados iniciadores específicos para cada transcrito por meio da utilização da ferramenta Primer3 (http://frodo.wi.mit.edu/cgi-bin/primer3/primer3.cgi) e as reações de padronização para cada par de oligonucleotídeo foram realizadas com o objetivo de selecionar a concentração que garantisse sua saturação. As concentrações de oligonucleotídeos testadas foram $0,2 \mu \mathrm{M} ; 0,4 \mu \mathrm{M} ; 0,6 \mu \mathrm{M}$ e $0,8 \mu \mathrm{M}$.

As reações de padronização foram processadas em volumes de $20 \mu \mathrm{L}$, contendo 10ng de cDNA proveniente de pool de amostras tumorais de língua, $10 \mu \mathrm{L}$ de Power Master Mix SYBR Green ${ }^{\mathrm{TM}}$ (Applied Biosystems) e os oligonucleotídeos iniciadores nas concentrações referidas na Tabela 2. O Power Master Mix SYBR Green ${ }^{\mathrm{TM}}$ contém todos os componentes para a reação de PCR em tempo real, exceto o template, os oligonucleotídeos iniciadores e a água. Para uma melhor análise dos resultados, os ensaios de otimização de concentração de oligonucleotídeos foram realizados em duplicata para cada gene analisado. Além disso, todos os experimentos incluíram controles negativos sem cDNA.

As reações compreenderam uma etapa inicial de 2 minutos a $50^{\circ} \mathrm{C}$ para a ativação da enzima UNG, seguida de um passo de 10 minutos a $95^{\circ} \mathrm{C}$ para inativação da UNG, evitando, dessa forma, que a enzima degradasse os produtos da termociclagem a ser iniciada em seguida, e também para a ativação da enzima AmpliTaq Gold® (Applied Biosystems). Posteriormente, seguiram-se 40 ciclos de 15 segundos a $95^{\circ} \mathrm{C}$ e um minuto a $60^{\circ} \mathrm{C}$ para extensão. Foi acrescentado um passo de dissociação que compreende duas etapas de 15 segundos a $95^{\circ} \mathrm{C}$, intercaladas por uma etapa de 30 segundos a $60^{\circ} \mathrm{C}$. A curva de dissociação tem como objetivo a verificação de ocorrência de primer dimers, produtos inespecíficos e de contaminações.

As eficiências de amplificação dos iniciadores específicos para os transcritos alvos e para o gene normalizador foram calculadas de acordo com a equação:

$$
\mathrm{E}=10^{(-1 / \text { slope })}
$$


Nessa equação, o slope corresponde à inclinação da reta obtida quando se analisa a variação do $\mathrm{Ct}$ dos transcritos alvo e do normalizador em função do log de diferentes quantidades de cDNA. Para verificar a eficiência de amplificação, foram realizadas diluições seriadas de cDNA da linhagem celular $F a D u$, sendo as concentrações finais iguais a 20ng, 10ng, 5ng, 2,5ng e 1,25ng. As amostras de cDNA nas concentrações citadas foram submetidas à amplificação por PCR em tempo real. O teste foi realizado para cada gene, sendo a concentração de oligonucleotídeo otimizada previamente.

Para cálculo da expressão diferencial, foi utilizado o modelo matemático proposto por PFAFFL, 2001 (Pfaffl 2001) segundo a fórmula,

$$
\mathrm{R}=(\mathrm{E} \text { alvo })^{\Delta \mathrm{Ct} \text { alvo }} /(\mathrm{E} \text { normalizador })^{\Delta \mathrm{Ct} \text { normalizador }}
$$

Nessa fórmula, o "E alvo" corresponde à eficiência de amplificação dos iniciadores específicos para o transcrito alvo, o "E normalizador" corresponde à eficiência de amplificação dos iniciadores específicos para o gene normalizador, o " $\Delta \mathrm{Ct}$ alvo" corresponde à diferença entre o Ct do transcrito alvo obtido para a amostra em análise e o $\mathrm{Ct}$ do transcrito alvo obtido para a amostra referência, o " $\Delta \mathrm{Ct}$ normalizador" corresponde à diferença entre o $\mathrm{Ct}$ do gene endógeno obtido para a amostra em análise e o Ct do gene endógeno obtido para a amostra referência.

\section{PCR em tempo real}

Após a etapa de padronização, foi realizada a análise da expressão diferencial do gene $M X 1$. As amostras foram testadas em duplicata com controles negativos. Foram considerados como diferencialmente expressos os transcritos que exibiram expressão diminuída nas linhagens transfectadas com os duplex para o $M X 1$ em relação às linhagens transfectadas com o controle negativo (duplex Scrambled), com valor superior ao cut off $(\geq 3.0)$ com base nos dois controles endógenos (GAPDH e TUBA1C). 


\section{Avaliação de ciclo e morte celular}

As células $S C C$-15 e $S C C$-25 foram mantidas em cultura por um período de 36 horas após ensaio de silenciamento gênico. As células foram tripsinizadas e centrifugadas juntamente com o meio de cultura, e o pellet foi fixado em etanol $70 \%$ e mantido congelado até o momento da análise por citometria de fluxo (citômetro FACScalibur Becton \& Dickson ${ }^{\circledR}$, Franklin Lakes - NJ, E.U.A). A avaliação de ciclo e morte celular foi realizada por meio da marcação com iodeto de propídeo (PI, do inglês propidium iodide). O PI se incorpora estequiometricamente ao DNA, permitindo uma quantificação relativa do conteúdo de DNA.

A análise da citometria de fluxo foi realizada utilizando o programa Cell Quest Pro $\left(\right.$ Becton \& Dickson $\left.{ }^{\circledR}\right)$. Cada condição foi avaliada em triplicata, a porcentagem das células nas diferentes fases do ciclo celular foi quantificada e os dados foram apresentados em histogramas. Para avaliar o papel do gene $M X 1$ sobre a proliferação celular em linhagens celulares de CECP foi realizado o cálculo da fração proliferativa das células. Para tanto, foi utilizada a seguinte razão:

$\mathrm{SG}_{2} \mathrm{M} / \mathrm{G}_{0} \mathrm{G}_{1}$

" $\mathrm{SG}_{2} \mathrm{M}$ " corresponde à população de células contidas em $\mathrm{M} 3$ e " $\mathrm{G}_{0} \mathrm{G}_{1}$ " corresponde à população de células contidas em M2 dos histogramas obtidos por citometria de fluxo. Uma razão maior ou menor que 1 indica aumento ou redução de proliferação, respectivamente.

\section{Ensaio de migração celular}

O efeito do silenciamento do gene $M X 1$ sobre o processo de migração celular foi investigado por meio do ensaio de "cicatrização de ferida" em cultura de monocamada. As células foram semeadas sobre lamínulas de vidro de $13 \mathrm{~mm}$ em placas de 24 poços e em câmaras de cultura de 2 poços. $\mathrm{O}$ experimento de silenciamento gênico por RNA de interferência foi realizado quando as células atingiram aproximadamente $90 \%$ de confluência. Transcorridas $24 \mathrm{~h}$ após a transfecção, foram realizadas, com o auxílio de uma ponteira de micropipeta, descontinuidades na monocamada confluente, criando dessa forma uma área livre de células (ferida). Em seguida, o meio foi retirado e as células foram lavadas três vezes com PBS para 
remoção dos restos celulares. Após um novo período de incubação de $12 \mathrm{~h}$, as células foram lavadas com PBS e fixadas com paraformaldeído 4\%. Foi realizada então a marcação dos núcleos com DAPI (4',6-diamidino-2-phenylindole), segundo protocolo estabelecido no laboratório. Para determinação da taxa de migração celular, as imagens das feridas foram capturadas com câmera digital Nikon DXM 1200F (Nikon Corporation, Tokyo, Japão) acoplada ao microscópio de fluorescência Nikon Eclipse E600 (Nikon Corporation) utilizando objetiva de 10 vezes. Duas barras paralelas às feridas foram inseridas sempre na mesma posição em todas as imagens obtidas e os núcleos localizados no interior destas barras foram contados.

\section{Análise estatística}

O programa GraphPad prism (GraphPad Software Inc., San Diego - CA, E.U.A.) foi utilizado para a confecção dos gráficos e análises estatíticas. A comparação das porcentagens médias de metilação entre os grupos controle (sangue normal), margens cirúrgicas e tumores foi realizada pela análise de variância (one-way ANOVA). Utilizou-se o Teste exato de Fisher para comparar a proporção de metilação do gene SLC15A3 e variáveis clínicas dos pacientes. Para tanto, foram considerados metilados os casos que apresentaram uma porcentagem de metilação maior que a média de metilação do grupo controle (sangue normal). A análise estatística dos resultados dos ensaios funcionais (migração, morte e ciclo celular) foi realizada pelo Teste $t$ Student (não paramétrico).

A significância estatística foi definida para os valores de $p \leq 0,05$ em todas as etapas da análise. 


\section{RESULTADOS E DISCUSSÃO}

\section{Casuística}

Foram analisadas 54 amostras de carcinomas epidermóides de cabeça e pescoço, que incluíram 42 amostras procedentes de carcinoma de laringe, 6 de carcinoma de língua e 6 de faringe. Cinquenta pacientes eram do sexo masculino e 4 do sexo feminino, com idades variando de 44 a 79 anos (média $=57,4$ anos); 53 referiram exposição ao tabaco, sendo 13 ex-fumantes; 47 pacientes faziam uso de álcool, mas 20 haviam abandonado o hábito etílico; 24 relataram exposição ao fumo e ao álcool. A classe TNM mais frequente foi a T4N2CM0 (Tabela 4).

\section{Avaliação de metilação do DNA por pirosequenciamento}

O perfil de metilação dos genes $M X 1$ e $S L C 15 A 3$ e de outros genes conhecidamente metilados em cabeça e pescoço (CDH1, CDH13, RASSF1A, DAPK1, CDKN2A, SOCS3 e TIMP3) foi avaliado por pirosequenciamento. O perfil de metilação da ilha $\mathrm{CpG}$ associada ao promotor da variante curta do gene $M X 1$ já havia sido avaliado anteriormente por MSP-PCR (methyl-specific PCR) e foi comparado com dados de pirosequenciamento em um painel de amostras independentes. Uma pequena parcela das amostras analisadas pelo método de pirosequencimento também já havia sido avaliada previamente por MSP-PCR.

Diversas metodologias têm sido utilizadas para avaliar perfis anormais de metilação do DNA em tumores humanos (Herman, Graff et al. 1996; Colella, Shen et al. 2003; Ogino, Odze et al. 2006), sendo a mais frequentemente utilizada a técnica de MSP-PCR (Herman, Graff et al. 1996). A MSP-PCR é um método de baixo custo, altamente sensível e reprodutível. Apesar disto, a técnica de MSP-PCR apresenta algumas limitações, como a possibilidade de falsos positivos devido à conversão inadequada de citosinas não metiladas para uracila. Outras variáveis, como número de ciclos de PCR, iniciadores inadequados, bem como qualidade do DNA utilizado, podem gerar dados dúbios. Por esse motivo, foi utilizada a metodologia de pirosequenciamento para avaliação do perfil de metilação de possíveis biomarcadores. 
Tabela 4. Frequência dos parâmetros sexo, idade, exposição a fumo e álcool, sítio primário, classificação estadio e diferenciação histológica das lesões em 54 pacientes portadores de carcinomas epidermóides de cabeça e pescoço segundo tamanho (T), comprometimento de linfonodos (N1-3) ou não (N0).

Sexo

Idade*

Fumante

Etilista

Sítio Primário

Classificação

$\begin{array}{ll} & \mathrm{N} 0 \\ \mathrm{~N} 1 \\ \mathrm{~N} 2 \\ \mathrm{~N} 3 \\ \mathrm{~N}-\mathrm{ND} \\ \\ \text { I } \\ \text { II } \\ \text { III } \\ \text { IV } \\ \text { NDtadio } & \\ & \text { Pouco diferenciado } \\ & \text { Moderadamente diferenciado } \\ & \text { Bem diferenciado } \\ \text { Diferenciação histológica } & \text { ND }\end{array}$

$50(92,6)$

Masculino

Feminino

$4(7,4)$

$37(68,5)$

$17(31,5)$

$40(74,2)$

$13(24,0)$

$1(1,8)$

$27(50,0)$

$20(37,0)$

$7(13,0)$

$42(78,0)$

$6(11,0)$

$6(11,0)$

$3(5,5)$

$8(14,8)$

$5(9,2)$

$35(65)$

$3(5,5)$

$21(39,0)$

$7(13,0)$

$20(37,0)$

$3(5,5)$

$3(5,5)$

$1(1,8)$

$4(7,4)$

$5(9,3)$

$29(53,7)$

$15(27,8)$

$5(9,3)$

$27(50)$

$17(31,4)$

$5(9,3)$

ND - Não determinado 
Em estudo prévio, o perfil de metilação do gene $M X 1$ foi encontrado como diferencialmente metilado em linhagens de CECP, bem com em amostras primárias de CECP (Calmon, Rodrigues et al. 2009). São conhecidos três transcritos do gene MX1 derivados de splicing alternativo, duas variantes curtas e uma terceira recentemente descrita. Esta última apresenta uma ilha $\mathrm{CpG}$ próxima à sua região promotora e as duas primeiras compartilham uma outra ilha $\mathrm{CpG}$ que tem início no final do primeiro exon e engloba grande parte do intron adjacente. (Figura 3).

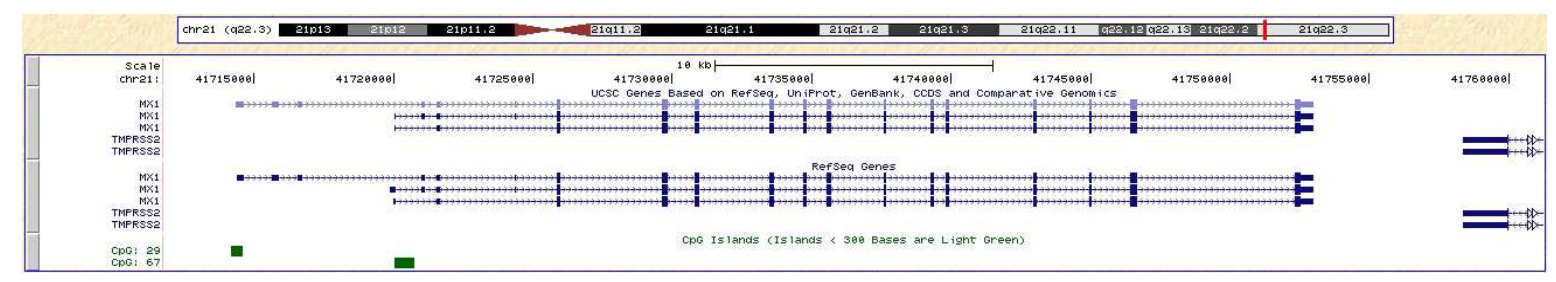

Figura 3 - Ferramenta BLAT mostrando localização e transcritos variantes do gene MXI. Caixas verdes - ilhas $\mathrm{CpG}$ analisadas no presente trabalho

Levando-se em conta as limitações técnicas do método de MSP-PCR, foi realizada a reavaliação de metilação do gene $M X 1$ por pirosequenciamento de DNA após tratamento com bissulfito de sódio. Para tanto, um ensaio de pirosequenciamento (sonda de pirosequencimento da região 2, isoformas curtas - Tabela 3 ) foi desenhado para a mesma região analisada pela técnica de MSP-PCR (Figura 4). Também foram desenhados dois outros ensaios próximos aos promotores associados a cada uma destes transcritos (Tabela 3).

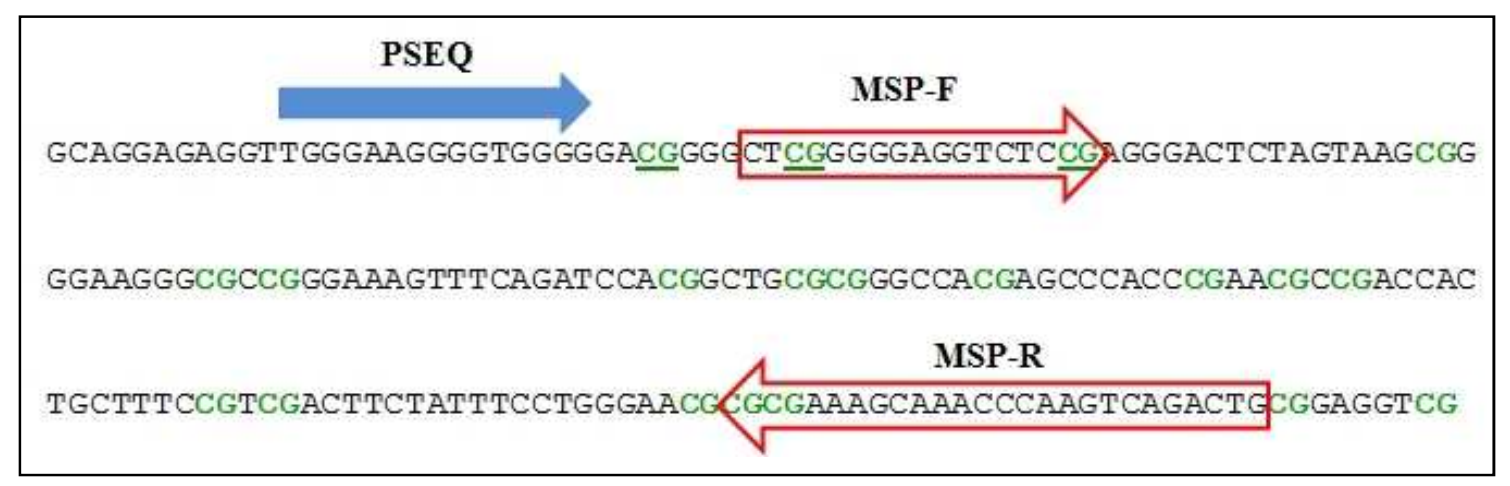

Figura 4 - Ensaios de pirosequenciamento e de MSP-PCR para detecção de metilação do DNA em dinucleotídeos CpGs no promotor do gene $M X 1$. Setas vermelhas - localização dos iniciadores utilizados nas reações de MSP-PCR. Seta azul - sonda de sequencimento utilizada no ensaio de pirosequenciamento. Verde - dinucleotídeos CpG. Sublinhado - dinucleotídeos $\mathrm{CpG}$ analisados nos ensaios de pirosequencimento. 
Como pode ser observado, a ilha $\mathrm{CpG}$ associada à variante longa não está metilada em amostras de indivíduos saudáveis, em tumores e suas respectivas margens cirúrgicas (Figura 5A). Os dinucleotídeos CpGs próximos ao sítio de início de transcrição da variante curta (região 1) também não estão metilados em amostras normais, margens cirúrgicas e tumores (Figura 5B). No entanto, a análise de dinucleotídeos CpGs distantes do promotor (região 2) mostrou que algumas amostras de CECP encontram-se metiladas (Figura 5C).

Como discutido acima, os resultados por pirosequenciamento mostraram muitas diferenças em relação aos dados obtidos pelo método de PCR-MSP. Um grupo de quinze amostras foi utilizado na comparação do perfil de metilação do gene $M X 1$ por estas duas metodologias. Dentre as amostras que apresentaram resultado positivo pelo método de PCR-MSP, apenas 10\% foram confirmadas pelo pirosequencimento. Essa enorme diferença deve-se, provavelmente, à característica qualitativa e à alta especificidade e sensibilidade do método de PCR-MSP. Por outro lado, o pirosequenciamento não possui a mesma especificidade e sensibilidade do MSP-PCR, pois seus iniciadores são desenhados fora de dinucleotídeos $\mathrm{CpG}$, o que favorece a amplificação de ambos os DNAs, metilado e não metilado. Dessa forma, caso a amostra tumoral apresente contaminação por DNA normal, a metilação presente no DNA tumoral pode ser mascarada pela presença de DNA não metilado proveniente da amostra normal.

O gene SLC15A3 foi encontrado como diferencialmente expresso e metilado em linhagens celulares tratadas com 5-AzadC, porém o seu perfil de metilação não foi avaliado anteriormente pela metodologia de MSP devido a dificuldades encontradas na padronização da reação de PCR. Por esse motivo, avaliamos o perfil de metilação deste gene apenas por pirosequencimento. Como pode ser observado, o gene encontra-se desmetilado em amostras de indivíduos sadios, porém o nível de metilação aumenta em margens cirúrgicas aparentemente livres de doença e está elevado em vários tumores (Figura 5D).

O perfil de metilação do DNA de alguns genes com papel importante na tumorigênese de cabeça e pescoço foi analisado com o objetivo de identificar uma assinatura molecular para esses tumores (Figura 6 A-G). Com exceção de uma pequena proporção de casos, a maioria desses genes encontra-se desmetilados nas amostras analisadas (Figura 6 A-G). 

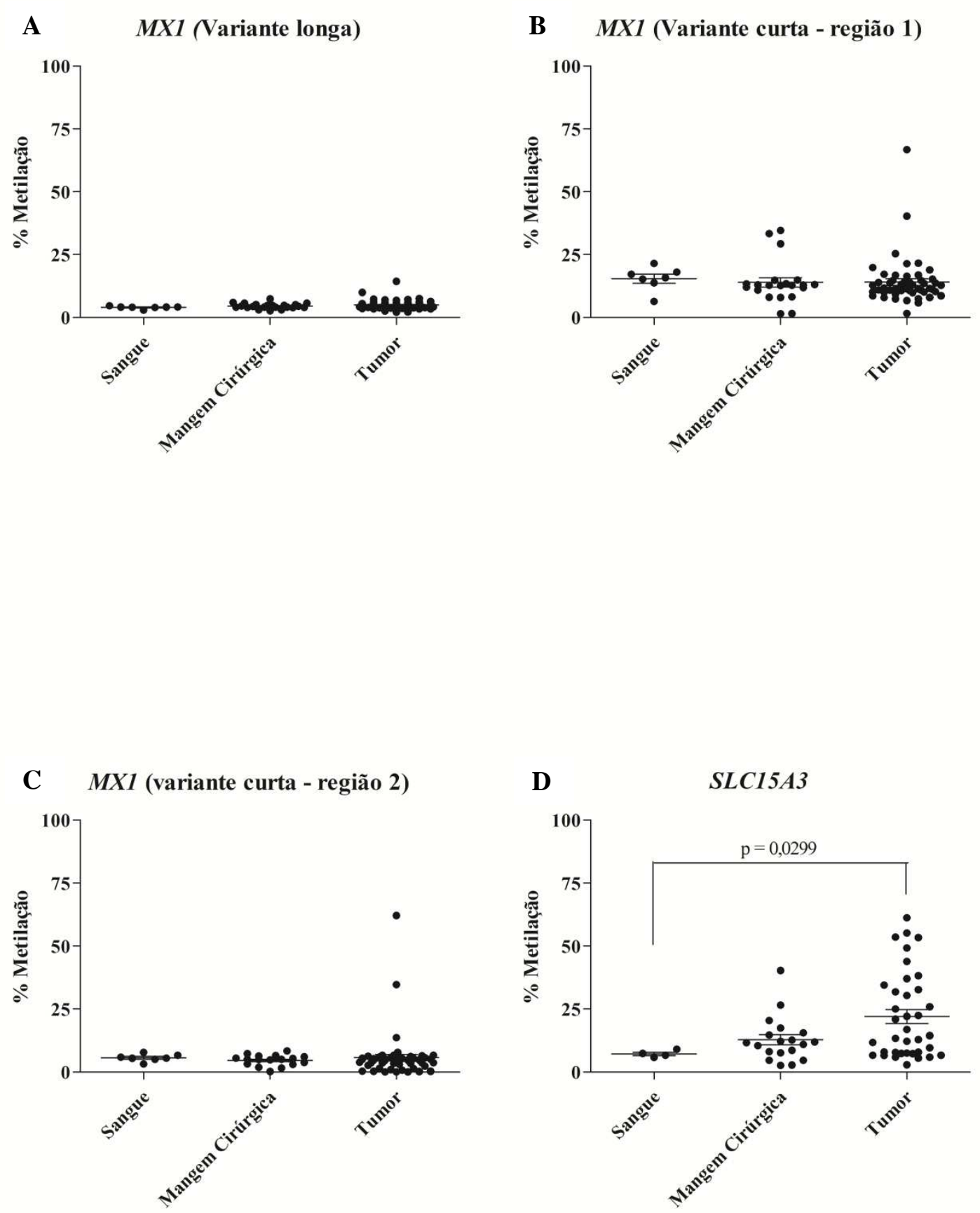

Figura 5. Metilação da ilha $\mathrm{CpG}$ associada às variantes do gene $M X 1$ e de dinucleotídeos $\mathrm{CpG}$ localizados na região promotora do gene SLC15A3 em amostras de indivíduos saudáveis, em tumores e suas respectivas margens cirúrgicas. 
A

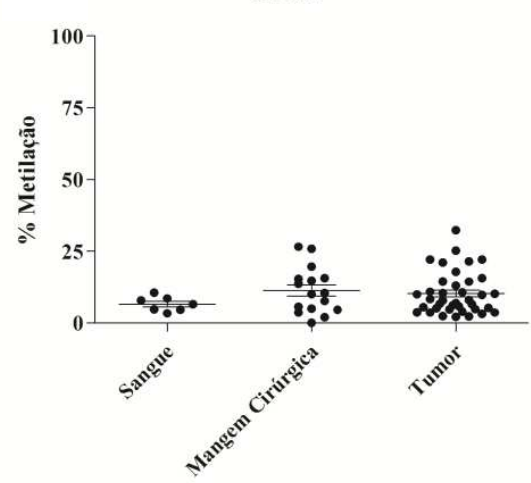

C

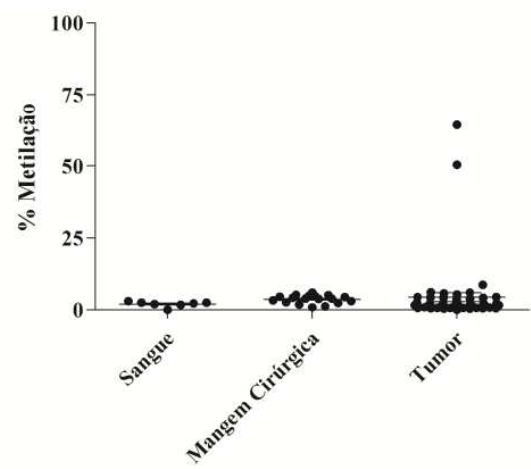

$\mathbf{E}$

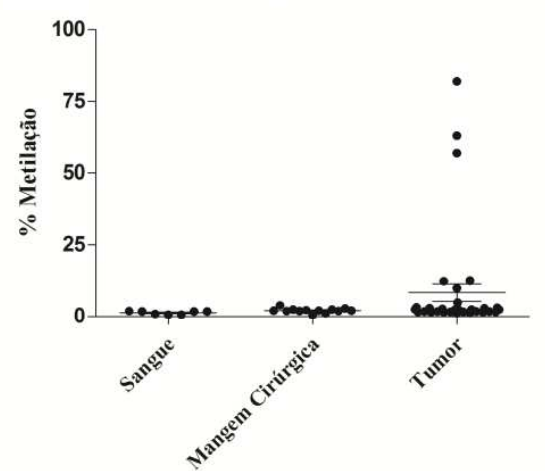

G

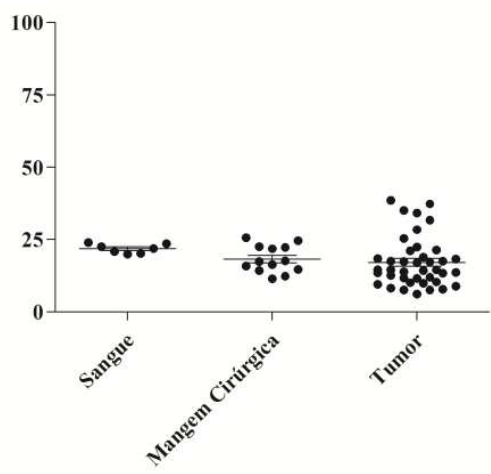

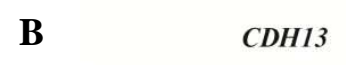

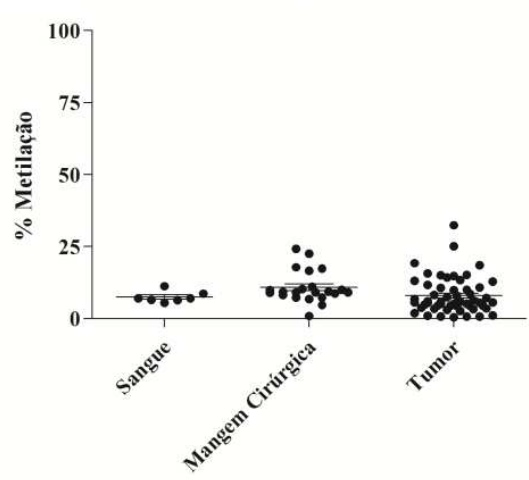

D DAPKI
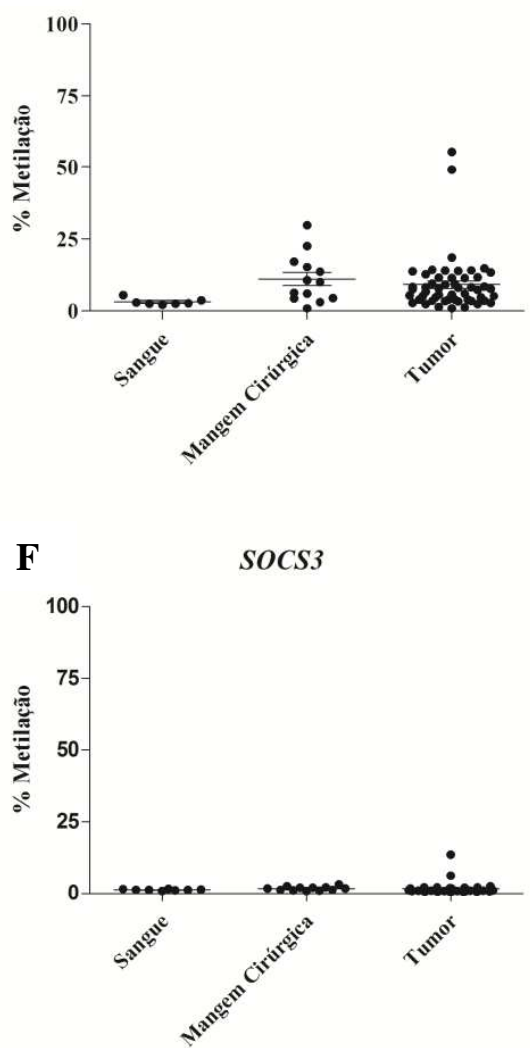

Figura 6. Metilação de ilhas CpGs associadas aos promotores dos genes CDH1, CDH13, RASSF1A, CDKN2A, DAPK1 e TIMP3 em amostras de indivíduos saudáveis, em tumores e suas respectivas margens cirúrgicas, bem como em linhagens. 
As análises estatísticas não mostraram diferenças significativas para a maioria dos genes analisados, com exceção do gene $S L C 15 A 3$, que apresentou diferença significativa $(\mathrm{p}<0,05)$ entre tumores e amostras de sangue de doadores saudáveis. No entanto, não houve diferença entre tumores e margens cirúrgicas aparentemente livres de doença. A Tabela 5 apresenta os dados da comparação de variáveis clínicas dos pacientes com o perfil de metilação do gene $S L C 15 A 3$, que mostrou associação com o grau de diferenciação dos tumores (Teste exato de Fisher; p<0,05).

O gene SLC15A3 faz parte de uma superfamília de transportadores de oligopeptídeos dependentes de prótons (POT), também denominados transportadores de peptídeos (PTR) (Steiner, Naider et al. 1995), que utilizam um mecanismo dependente de prótons para o transporte transmembrânico de pequenas cadeias peptídicas (HerreraRuiz and Knipp 2003; Daniel and Kottra 2004). As proteínas POT possuem entre 450 e 700 aminoácidos, com as variantes de procariotos sendo menores que as de eucariotos. As predições protéicas indicam que essas proteínas possuem 12 domínios transmenbrânicos (TMD) com as porções carboxi- e amino-terminais voltadas para o citosol (Steiner, Naider et al. 1995).

Em humanos, foram descritos primeiramente dois membros dessa família, PEPT1 (SLC15A1) e PEPT2 (SLC15A2), ambos com a capacidade de transportar uma ampla variedade de di e tripeptídeos. Entretanto, essa capacidade diminui drasticamente com o aumento do tamanho dos peptídeos (Liu, Liang et al. 1995). Posteriormente, foram descritos dois outros genes dessa família, PHT1 (SLC15A4) e PHT2 (SLC15A3), e suas isoformas derivadas de splincing alternativo (Botka, Wittig et al. 2000; HerreraRuiz, Wang et al. 2001).

Os genes da família POT possuem um padrão de expressão tecido-específico e, interessantemente, também estão relacionados com o transporte de diversas drogas peptídeo-miméticas (Terada, Sawada et al. 2000; Shu, Shen et al. 2001; Watanabe, Sawano et al. 2002; Wenzel, Kuntz et al. 2002). Isto faz com que sejam de particular interesse para o desenvolvimento de drogas tecido-específicas.

YAMASHITA et. al. (1997) (Yamashita, Shimada et al. 1997), analisando o perfil de expressão de PHT1 em tecidos de rato por Northern blot, obtiveram confirmação de expressão em cérebro, olho, pulmão e baço. As análises em tecidos humanos mostraram expressão de PHT1 em intestino delgado (Bhardwaj, Herrera-Ruiz et al. 2006) e expressão elevada de seu produto (proteína hPept1) (Qual gene? O PHT1 ou SLC15A4) em pancreatite (Gonzalez, Covitz et al. 1998) e na linhagem celular Caco- 
2 derivada de adenocarcinomas de cólon (Walker, Thwaites et al. 1998). Uma revisão recente sobre o gene SLC15A3 (peptide/histidine transporter 2) mostrou escassez de dados sobre sua função.

Tabela 5. Relação entre perfil de metilação do gene $S L C 15 A 3$ e variáveis clínicopatológicas de pacientes com CECP.

\begin{tabular}{|c|c|c|c|c|}
\hline Variáveis clinico - patológicas & Categoria & \multicolumn{3}{|c|}{ SLC15A3 } \\
\hline \multirow{3}{*}{ Idade } & & Não metilado & Metilado & $\mathrm{P}$ \\
\hline & $\leq 60$ & 11 & 26 & \multirow{2}{*}{0,4073} \\
\hline & $>60$ & 7 & 10 & \\
\hline \multirow{2}{*}{ Tamanho do tumor } & $\mathrm{T} 1+\mathrm{T} 2$ & 4 & 7 & \multirow{2}{*}{0,8112} \\
\hline & $\mathrm{T} 3+\mathrm{T} 4$ & 14 & 29 & \\
\hline \multirow{3}{*}{ Grau } & 1 & 4 & 1 & $0.0326 *(1-2)$ \\
\hline & 2 & 8 & 19 & $0.6945(2-3)$ \\
\hline & 3 & 6 & 11 & $0.0776(1-3)$ \\
\hline \multirow{3}{*}{ Sítio anatômico } & Laringe & 13 & 27 & $0.6761(1-2)$ \\
\hline & Faringe & 2 & 6 & $0.334(2-3)$ \\
\hline & Língua & 3 & 3 & $0.4013(1-3)$ \\
\hline \multirow{2}{*}{ Estadio } & $\mathrm{I}+\mathrm{II}$ & 3 & 2 & \multirow{2}{*}{0,1755} \\
\hline & $\mathrm{III+IV}$ & 10 & 24 & \\
\hline \multirow{2}{*}{ Comprometimento linfonodal } & N0 & 9 & 18 & \multirow{2}{*}{1,000} \\
\hline & $\mathrm{N}+$ & 9 & 18 & \\
\hline
\end{tabular}

$* \mathrm{p}<0,05$ (teste exato de Fisher) 


\section{Comparação do perfil de expressão gênica com o padrão de metilação do} promotor

Nesta etapa do trabalho, foi investigado se a expressão dos genes $M X 1 \mathrm{e}$ SLC15A3 está associada com o padrão de metilação do DNA em seus promotores. Para tanto, os perfis de expressão gênica e de metilação do DNA foram analisados em diversas linhagens celulares. Os transcritos dos genes MX1 e SLC15A3 apresentam expressão diminuída em linhagens celulares em relação aos linfócitos normais (Figura 7 A, C, E). Entretanto, a ilha $\mathrm{CpG}$ associada ao promotor da variante longa do gene $M X 1$ apresenta baixos níveis de metilação (Figura 7B) na maioria das linhagens celulares analisas. Ao contrário, a região do DNA próxima ao promotor da ilha CpG (+53/+97) associada aos transcritos curtos do gene $M X 1$ está altamente metilada em praticamente todas as linhagens celulares (Figura 7D), o que concorda com as análises de transcritos. O gene SLC15A3 também apresentou altos níveis de metilação do DNA próxima ao início sítio de transcrição (Figura 7F).

\section{Ensaios funcionais do gene $M X 1$ em linhagens celulares de cabeça e} pescoço

Para investigar o efeito do silenciamento da expressão do gene $M X 1 \mathrm{em}$ linhagens celulares de cabeça e pescoço, foram realizadas análises do índice de proliferação, migração e ciclo celular. Esses parâmetros forma avaliados após o silenciamento da expressão gênica por RNA de interferência contra o $M X 1$.

\section{Curvas de proliferação celular}

A morfologia e o potencial proliferativo das linhagens celulares de carcinomas epidermóides de cavidade oral (SCC-4, SCC-9, SCC-15, SCC-25) foram comparados. Essas linhagens, apesar de derivarem de CECs de língua, apresentam características biológicas bastante diferentes. As linhagens SCC-4 e SCC-15 mostraram-se similares no aspecto morfológico, ambas com células grandes e arredondadas com nucléolos evidentes, multinucleadas e crescimento formando redes (Figura 8A e 8C). 

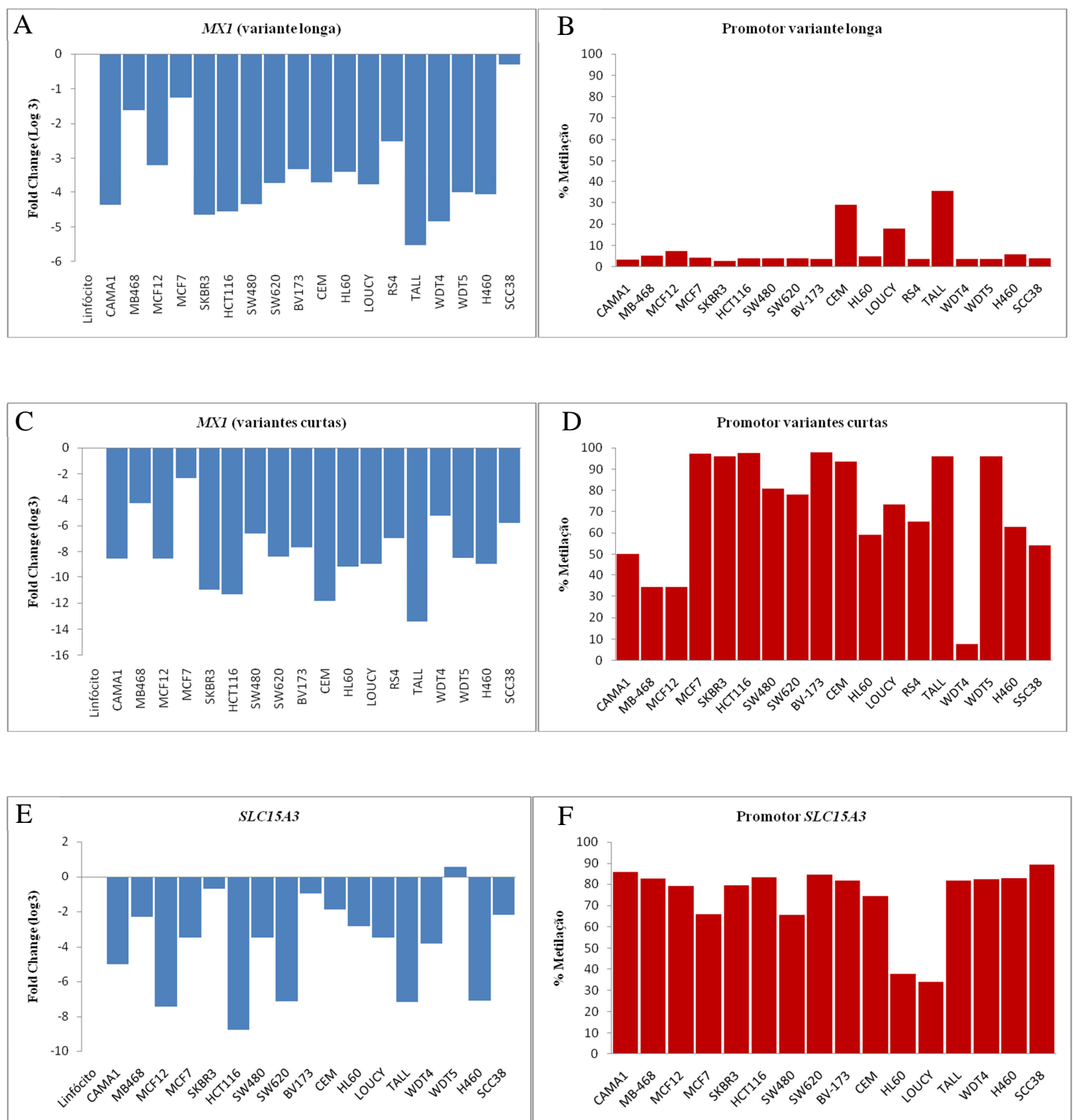

Figura 7. Perfis de expressão gênica e de metilação de ilhas CpGs associadas aos promotores dos genes $M X 1$ e $S L C 15 A 3$ em linhagens celulares provenientes de tumores de cabeça e pescoço, mama, cólon, leucemias e pulmão. A - qRT-PCR do gene MX1 ( transcrito variante longo), B - \% metilação da ilha $\mathrm{CpG}$ associada ao promotor da variante longa do gene $M X 1$. C - qRT-PCR do gene $M X 1$ ( transcritos curtos), D - \% metilação promotor ilha CpG associada ao promotor das variantes curtas do gene $M X 1$. E - qRT-PCR do gene $S L C 15 A 3$, F - \% metilação promotor ilha $\mathrm{CpG}$ associada ao promotor do gene $S L C 15 \mathrm{~A} 3$. 
A linhagem SCC-9 apresentou um padrão de crescimento em rede e suas células mostraram núcleos grandes com nucléolos bastante evidentes, também arredondadas, porém raramente multinucleadas, e menores que as observadas em SCC4 e SCC-15 (Figura 8B). A linhagem SCC-25 apresentou células pequenas, com aspecto variando de arredondado a fusiforme, citoplasma escasso, núcleo grande e nucléolos evidentes (Figura 8D). O padrão de crescimento desta linhagem foi diferente, sendo observada a formação de pequenos grumos.
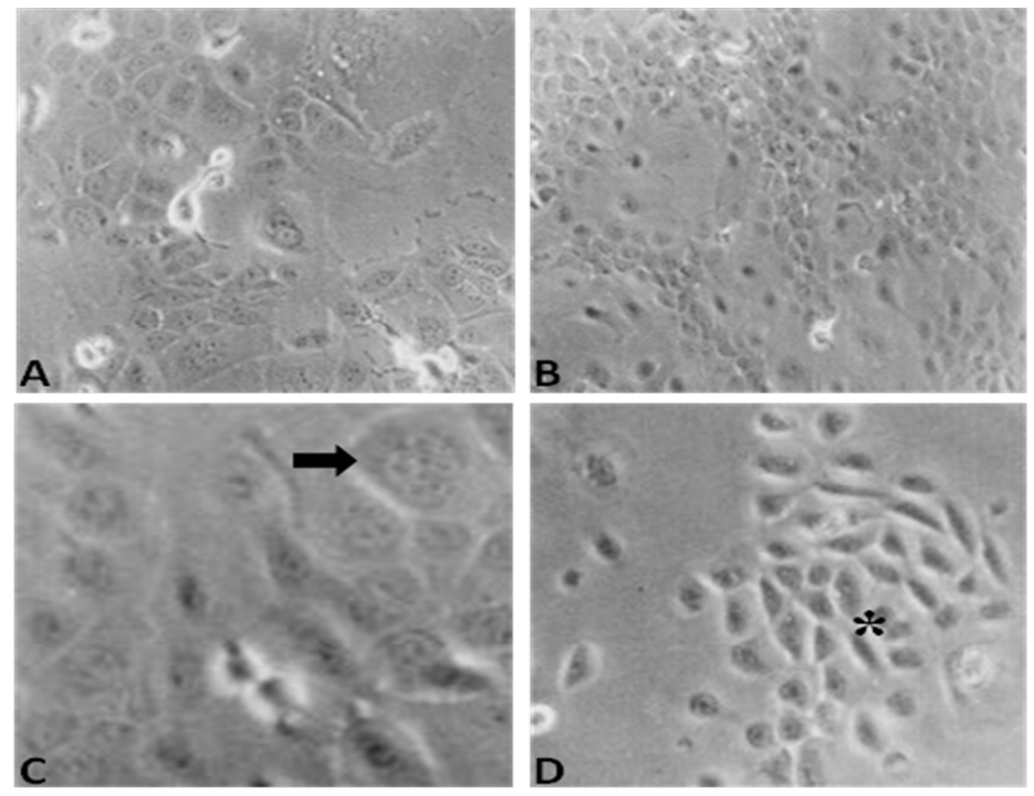

Figura 8. Aspecto morfológico das linhagens celulares $S C C-4$ (A), SCC-9 (B), SCC-15 (C) e SCC-25 (D) em culturas subconfluentes, observadas em aumento de 100x. Em A observase a presença de nucléolos evidentes, em $\mathbf{B}$ a formação de redes de células característica da linhagem SCC-9, em C células multinucleadas (seta) e em $\mathbf{D}$ células fusiformes presentes na linhagem $S C C$-25 com seu típico crescimento em grumos (*). 
A linhagem que apresentou maior potencial proliferativo foi a $S C C-25$, com maior número de células em todos os períodos. As linhagens $S C C-4$, SCC-9 e SCC-15 comportaram-se de maneira semelhante, não havendo grandes diferenças entre elas nos intervalos de tempo analisados. De maneira geral, o pico de proliferação variou entre 144 e 168 horas para todas as linhagens. No período de 192 horas após o plaqueamento, observou-se com freqüência um declínio no número de células, provavelmente por causas da proximidade da fase de confluência, o que provoca morte celular (Figura 9).

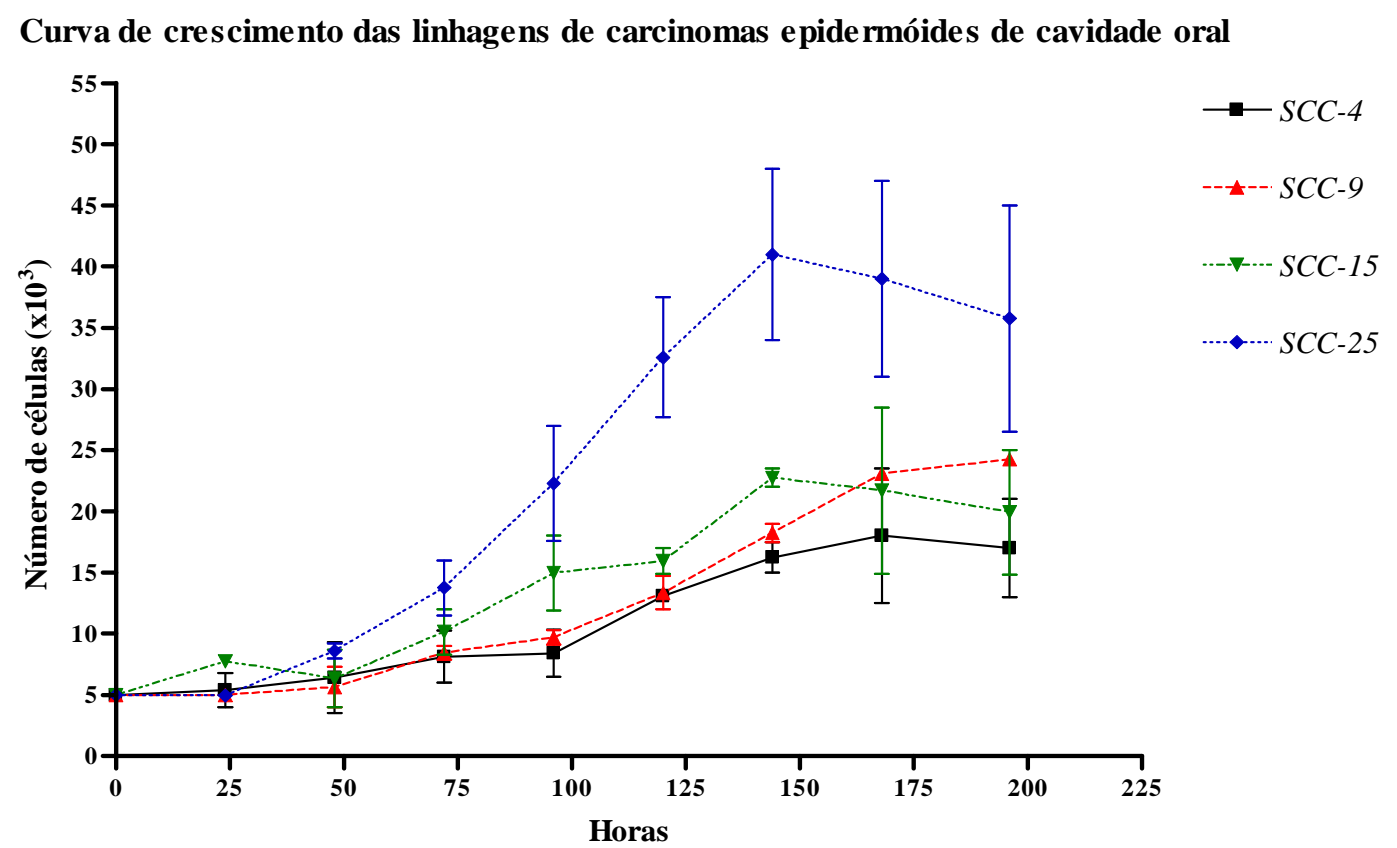

Figura 9. Curvas de proliferação das linhagens de carcinomas epidermóides de cabeça e pescoço $S C C$-4, SCC-9, SCC-15, SCC-25.

\section{Silenciamento da expressão do gene MX1 por RNA de interferência}

A padronização dos experimentos de silenciamento da expressão do gene $M X 1$ foi realizada, primeiramente, com a linhagem $S C C-9$, utilizando três oligos duplex de 27mer, específicos para o gene $M X 1$, em diferentes concentrações (1nM, 10nM e 20nM). O RNA foi isolado e serviu de molde para a síntese de cDNA. Os níveis dos transcritos do MX1 foram avaliados por PCR em tempo real. Nesses experimentos, foi verificado que a expressão do gene $M X 1$ está reduzida após tratamento com oligos 
específicos para esse transcrito. A lipofectamine RNAiMax apresentou menor toxicidade que a lipofectamine 2000 e mostrou-se mais eficiente no silenciamento do transcrito (Figura 10). Foram considerados como diferencialmente expressos os valores superiores ao cut off ( $\geq 3.0$ ) com base nos dois controles endógenos (GAPDH e TUBAIC). Os dados de eficiência de amplificação dos oligonucleotídeos utilizados nas reações de PCR em tempo real, bem como sua sequencias e concentrações, estão apresentados na Tabela 6.
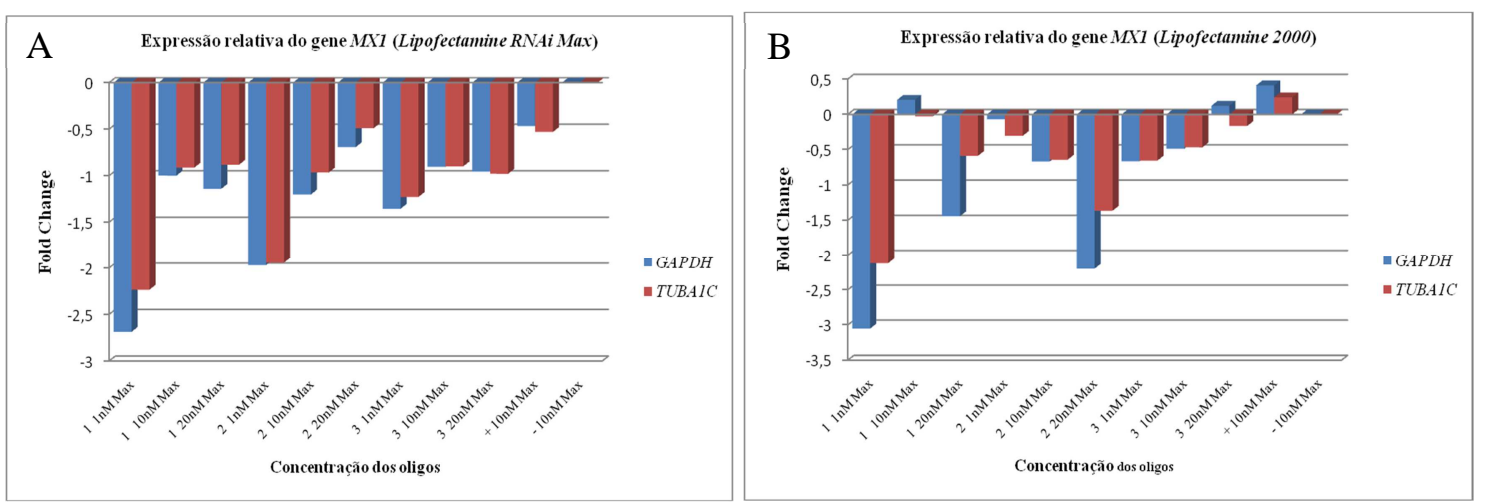

Figura 10 -Expressão relativa do gene $M X 1$ após ensaio de silenciamento com RNAi. A agente de transfecção Lipofectamine RNAi Max. B - agente de transfecção Lipofectamine 2000.

Tabela 6. Seqüência, concentração otimizada, slope e $R 2$ dos oligonucleotídeos utilizados para as amplificações por PCR em tempo real.

\begin{tabular}{|c|c|c|c|c|c|}
\hline Genes & & $5^{\prime} \rightarrow 3^{\prime}$ & Concentração & Slope & $R 2$ \\
\hline$M X 1$ & $\begin{array}{l}\text { senso } \\
\text { antisenso }\end{array}$ & $\begin{array}{c}\text { CAATCAGCCTGCTGACATTG } \\
\text { TGTCTCCTGCCTCTGGATG }\end{array}$ & 0,4 & $-3,450$ & 0,99 \\
\hline TUBA6 & $\begin{array}{l}\text { senso } \\
\text { antisenso }\end{array}$ & $\begin{array}{c}\text { TCAACACCTTCTTCAGTGAAACG } \\
\text { AGTGCCAGTGCGAACTTCATC }\end{array}$ & 0,6 & $-3,341$ & 0,99 \\
\hline GAPDH & $\begin{array}{l}\text { senso } \\
\text { antisenso }\end{array}$ & $\begin{array}{c}\text { ACCCACTCCTCCACCTTTGA } \\
\text { CTGTTGCTGTAGCCAAATTCGT }\end{array}$ & 0,4 & $-3,392$ & 0,99 \\
\hline
\end{tabular}




\section{Avaliação de ciclo e morte celular}

Para avaliar o efeito silenciamento do gene $M X 1$ sobre o processo de morte celular em linhagens celulares de cabeça e pescoço, foi realizada análise por citometria de fluxo, após incorporação de iodeto de propídeo, das células transfectadas com o oligo para o transcrito de $M X 1$ e com o controle negativo (Scrambled) após 36 horas da transfecção. Aparentemente, o silenciamento do gene $M X 1$ não interfere nos eventos de morte celular nas linhagens avaliadas, sendo a porcentagem de morte (M1) baixa em ambas as linhagens avaliadas e sem diferenças consideráveis entre os grupos controle e tratado (Tabelas 7-8) (Figuras 11-12).

Tabela 7. Porcentagem de eventos em cada fase na linhagem $S C C-15$

\begin{tabular}{ccccc}
\hline \multicolumn{5}{c}{ SCC-15 } \\
\hline Mcrambled & 3,79 & M2(\%) & M3(\%) & M4(\%) \\
MX1 & 3,19 & 24,51 & 37,45 & 6,45 \\
\hline
\end{tabular}
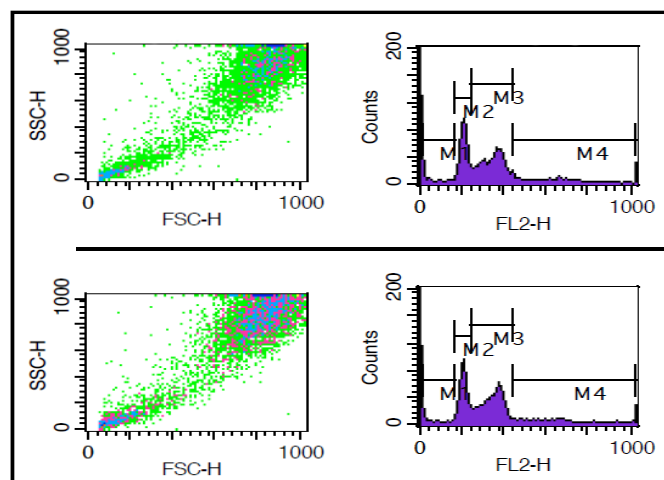

Figura 11. Exemplos de histogramas obtidos com as análises de morte e ciclo celular por citometria de fluxo na linhagem SCC-15.
Tabela 8. Porcentagem de eventos em cada fase na linhagem $S C C-25$

\begin{tabular}{ccccc}
\hline \multicolumn{5}{c}{ SCC-25 } \\
\hline \multirow{3}{*}{ Scrambled } & 2,31 & 43,01 & 46,76 & 2,96 \\
MX1 & 3,57 & 39,71 & 50,70 & 2,76 \\
\hline
\end{tabular}

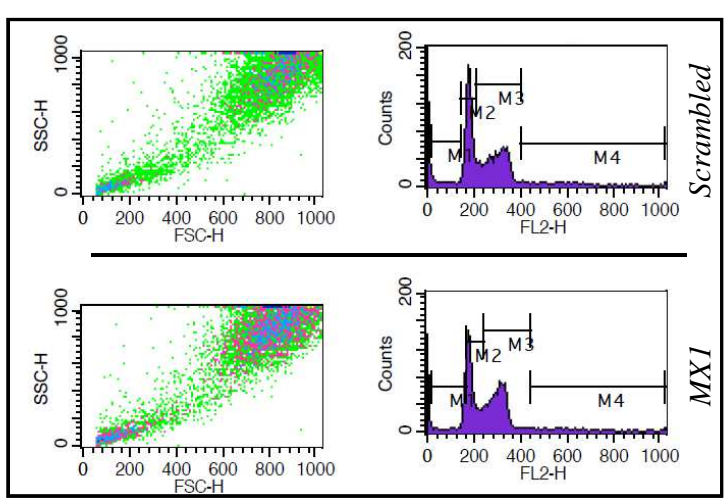

Figura 12. Exemplos de histogramas obtidos com as análises de morte e ciclo celular por citometria de fluxo na linhagem $S C C-25$. 
A avaliação da fração de células em estado proliferativo mostrou um aumento aparente do número de células em fase proliferativa quando o gene $M X 1$ está silenciado em ambas as linhagens (Figuras 13 A-B). A linhagem SCC-15 proliferou aproximadamente 1,31 vezes mais na amostra transfectada com o oligo para o MX1 do que o controle negativo (Figura 13A), enquanto a linhagem SCC-25 apresentou um aumento de 1,18 vezes (Figura 13B).

A

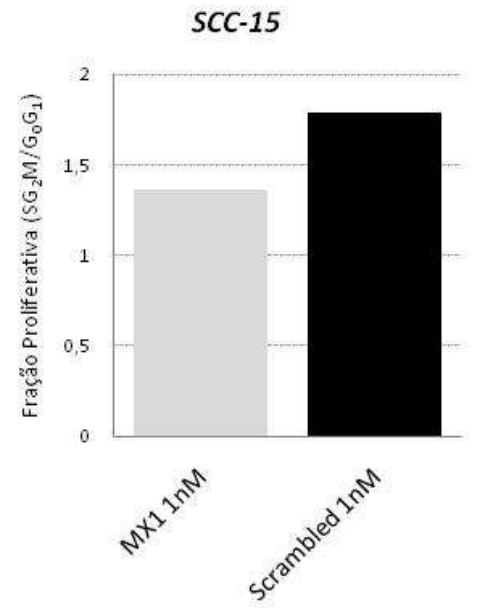

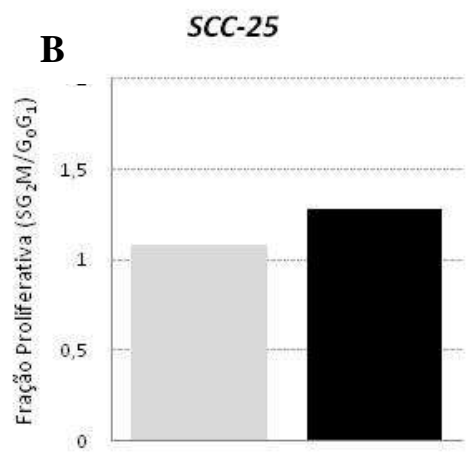

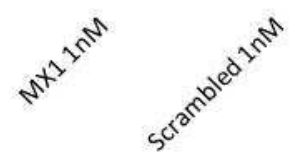

Figura 13. Gráficos da fração proliferativa, construídos a partir da análise dos resultados obtidos por citometria de fluxo, de linhagens celulares de carcinoma epidermóide de cabeça e pescoço após ensaios de RNAi . A - linhagem SCC-15. B - linhagem SCC25

Ensaio de migração celular (Ensaio de “cicatrização de ferida" em

\section{monocamada)}

O ensaio de migração celular foi realizado com as linhagens $S C C$-4 e $S C C-25$ transfectadas com oligo contra o transcrito do gene MXI (Figuras 14B-D) e com o controle negativo (Figura 14A-C). Foram capturadas imagens das "feridas" em cada uma das condições experimentais doze horas após a realização do ensaio de RNA de interferência.

A linhagem SCC-25 mostrou um aumento significativo da migração nas células tratadas com o oligo contra o gene $M X 1$ quando comparada com as células transfectadas com o controle negativo ( $\mathrm{p}<0,05$ ) (Figura 15B). A linhagem $S C C-4$ também apresentou um aumento número de células que migraram após transfecção com o oligo contra o MXI quando comparado com o controle. No entanto, esse aumento de migração não foi significativo $(\mathrm{p}=0,06)$ (Figura $15 \mathrm{~A})$. 


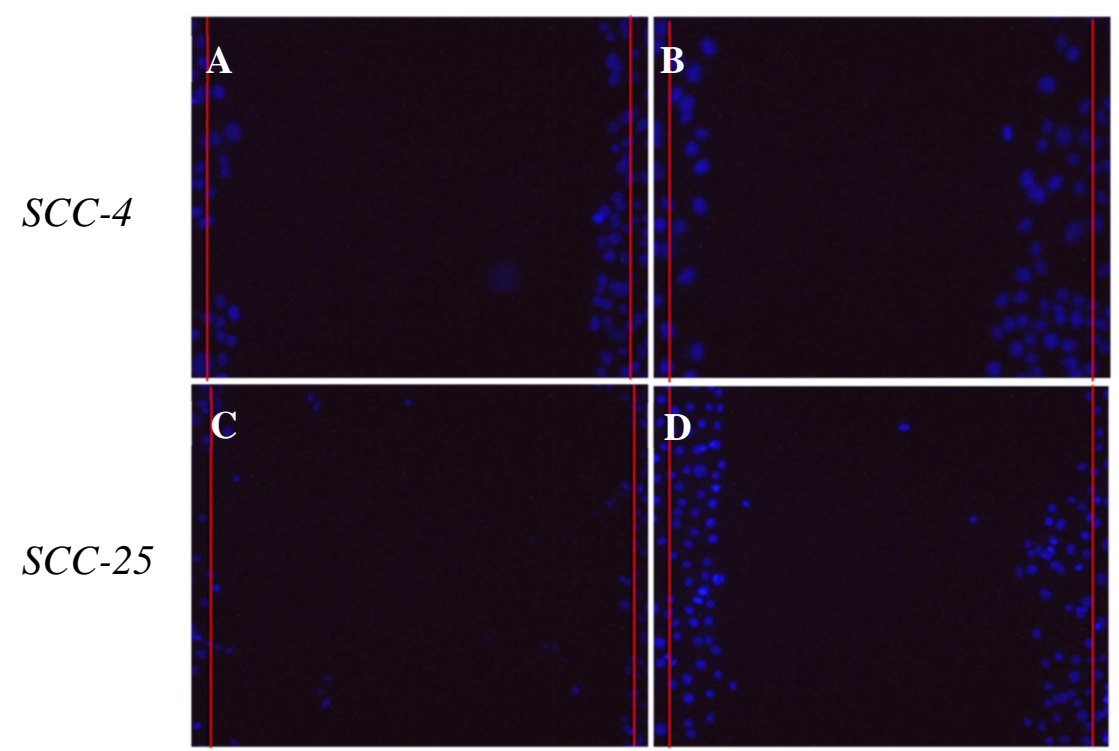

Figura 14. Fotomicrografias das regiões submetidas ao ensaio de ferida mostrando núcleos corados com DAPI. As barras paralelas vermelhas foram usadas como referencial para a contagem dos núcleos. Objetiva de 10X.

A

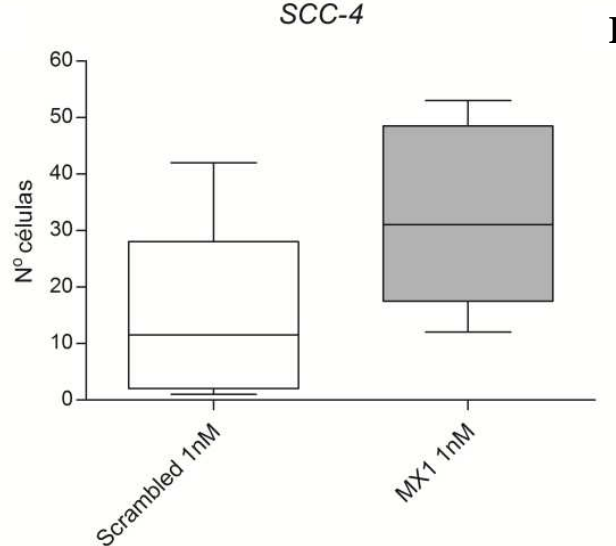

B

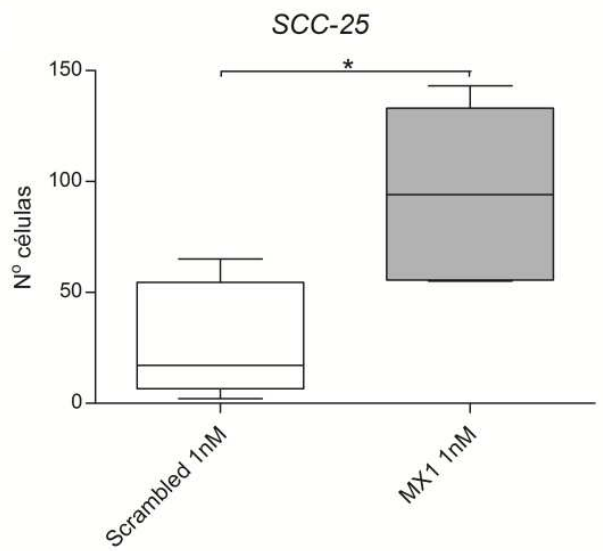

Figura 15. Gráficos comparativos da contagem de núcleos em experimentos de migração com linhagens celulares de carcinoma epidermóide de cabeça e pescoço após ensaios de transfecção de oligos para o gene $M X 1$ e controle negativo. A - linhagem $S C C-4$ ( $\mathrm{n}=8$ campos). B linhagem $S C C-25$ ( $\mathrm{n}=5$ campos) Teste $t$ Student (não paramétrico) - *p $<0,05$ 
O gene MX1 (myxovirus resistance 1) está mapeado no braço longo do cromossomo 21 na posição 22.3 e codifica um membro da superfamília de dinaminas de grandes GTPases, que modulam o tráfico de vesículas e homeostase de organelas (Haller, Staeheli et al. 2007). Similarmente a outras proteínas Mx, a proteína humana MX1 contém um domínio de GTPase na região amino-terminal, um domínio interativo no meio da molécula e um zíper de leucina na região C-terminal (Horisberger, McMaster et al. 1990).

A MX1 possui atividade antiviral contra diversos vírus de RNA e é transcricionalmente induzida por interferon pela via JAK/STAT (Holzinger, Jorns et al. 2007). Aparentemente, essa proteína citoplasmática reconhece e liga-se ao nucleocapsídeo viral e previne a transcrição e a replicação viral (Schwemmle, Richter et al. 1995; Kochs and Haller 1999). O MX1 mostra expressão elevada em células de alguns grupos de complementação da anemia de Fanconi e pode estar relacionado com algumas características fenotípicas dessa doença (Altschul, Madden et al. 1997). Por outro lado, exibe expressão reduzida em câncer de próstata (Schulz, Alexa et al. 2007) e encontra-se metilado em células de leucemia mielóide aguda (Desmond, Raynaud et al. 2007). Os dados do presente estudo mostraram que a região promotora do gene $M X 1$ também encontra-se metilada em linhagens celulares e tumores primários de carcinoma epidermóide de cabeça e pescoço (Calmon, Rodrigues et al. 2009), sugerindo uma provável ligação entre o silenciamento de $M X 1$ e a tumorigênese. Essa hipótese é reforçada pelos achados de MIBAYASHI e colaboradores (Mibayashi, Nakad et al. 2002), de que o $M X 1$ promove morte celular induzida por estímulos apoptóticos. Portanto, baixos níveis de MX1 devem contribuir para a resistência à apoptose durante o desenvolvimento do câncer.

NOSER e colaboradores (Noser, Mael et al. 2007) também apontam o silenciamento de $M X 1$ como um importante processo na tumorigênese. Esses autores observaram que células humanas com a via RAS/Raf1/MEK/ERK ativada e sensíveis à morte celular induzida pelo vírus da estomatite vesicular mostram baixa eficiência na indução da expressão de $M X 1$. No entanto, nos ensaios inicias de citometria de fluxo, não foram identificadas modificações significativas nos padrões de morte celular em linhagens celulares de cabeça e pescoço com o gene $M X 1$ silenciado.

Recentemente, MUSHINSKI e colaboradores (Mushinski, Nguyen et al. 2009), demonstraram que a proteína MX1 inibe a motilidade e a capacidade invasiva de linhagens celulares de próstata e seus dados sugerem que a indução da expressão dessa 
proteína pode ser usada na prevenção e no tratamento de metástases. Os resultados de experimentos de migração celular (“cicatrização de ferida"), obtidos no presente trabalho, apóiam essa hipótese e indicam que o $M X 1$ atua nos processos de migração celular e que sua ausência pode favorecer a progressão tumoral e a formação de metástases. 


\section{CONCLUSÕES}

O presente trabalho teve as seguintes conclusões:

1. A ilha $\mathrm{CpG}$ associada ao promotor da variante longa do gene $M X 1$ não está metilada em carcinomas epidermóides de cabeça e pescoço. Uma pequena parcela das amostras analisadas no presente trabalho está metilada na ilha $\mathrm{CpG}$ próxima ao sítio de início de transcrição dos transcritos curtos do gene $M X 1$. O promotor do gene SLC15A3 é frequentemente metilado em carcinomas epidermóides de cabeça e pescoço e está relacionado com o grau de diferenciação do tumor.

2. Os genes $C D H 1, C D H 13, D A P K, C D K N 2 A, R A S S F 1 A, S O C S 3$ e TIMP3 são metilados em uma pequena parcela dos tumores analisados no presente trabalho. Não existe um padrão de metilação destes genes entre as amostras analisadas.

3. A comparação dos níveis de expressão com o perfil de metilação do gene $M X 1$, em linhagens celulares tumorais, indicou que a metilação do promotor deste gene não regula sua expressão.

4. A comparação dos níveis de expressão com o perfil de metilação do gene SLC15A3, em linhagens celulares tumorais, indicou que a metilação do promotor deste gene não regula sua expressão.

5. A redução dos níveis dos transcritos do gene $M X 1$ modula a proliferação e ciclo celular, bem como aumenta a motilidade de linhagens celulares de carcinomas epidermóides de cabeça e pescoço. 


\section{RESUMO}

A programação epigenética do genoma por metilação do DNA, modificação das histonas e remodelamento da cromatina é crucial para o desenvolvimento e o crescimento normal dos mamíferos e alterações nesses mecanismos contribuem diretamente para a transformação maligna. Em função do papel relevante da metilação do DNA na carcinogênese, da importância e da necessidade de identificação de marcadores moleculares em tumores de cabeça e pescoço e dos resultados já obtidos pelo grupo, o presente trabalho teve por objetivo geral investigar o perfil de metilação de ilhas CpG em carcinomas primários de cabeça e pescoço (CECP), bem como identificar e iniciar estudos funcionais de biomarcadores candidatos para diagnóstico e prognóstico desses tumores. Alguns genes previamente descritos com padrões anormais de metilação em neoplasias humanas (CDH1, CDH13, DAPK, CDKN2A, RASSF1A, SOCS3 e TIMP3), além de outros dois genes (MX1 e SLC15A3) identificados em nosso estudo anterior, foram analisados em amostras normais e margens cirúrgicas de CECP por meio da técnica de pirosequencimento de DNA após tratamento com bissulfito de sódio. As análises estatísticas não mostraram diferenças significativas para a maioria dos genes analisados, com exceção do gene $S L C 15 A 3$, que apresentou diferença significativa $(\mathrm{p}<0,05)$ entre tumores e amostras de sangue de doadores saudáveis. Diferentemente, os resultados obtidos com a metodologia de PCR-MSP em nosso trabalho anterior mostraram que o gene $M X 1$ está metilado em CECP. Os estudos funcionais do $M X 1$, por RNA de interferência, ensaios de migração e citometria de fluxo mostraram que seu produto contribui para migração e proliferação celular, e talvez para resistência à apoptose. Os resultados sugeriram que o nível de expressão do $M X 1$ pode ser um preditor do potencial metastático em carcinoma epidermóide. 
The genome epigenetic programming by DNA methylation, histone modification and chromatin remodeling is crucial for normal growth and development in mammals and changes in these mechanisms contributes directly to malignant transformation. Regarding the role of DNA methylation in carcinogenesis, the importance and necessity for the identification of molecular markers in head and neck tumors, and the results already obtained by the group, this study was aimed at investigating the methylation profile of $\mathrm{CpG}$ islands in primary head and neck squamous cell carcinomas (HNSCC), and to identify and initiate functional studies of candidate biomarkers for diagnosis and prognosis of these tumors. Therefore, some genes previously described with abnormal methylation pattern in humans tumors (CDH1, CDH13, DAPK, CDKN2A, RASSF1A, and TIMP3 SOCS3), and two other genes (MX1 and SLC15A3) identified in our previous study were analyzed in normal samples, surgical margins, and in HNSCC by pyrosequencing after sodium bisulfite treatment. The statistical analysis showed no significant differences for most of analyzed genes, except for the SLC15A3, which showed significant difference $(\mathrm{p}<0.05)$ between tumors and blood samples from healthy donors. However, our earlier results showed a higher frequency of $M X 1$ hypermethylation in primary HNSCC using the PCR-MSP methodology. To gain a better understanding of the role $M X 1$ in cancer biology we investigated whether a downregulation of $M X 1$ by interference RNA contribute to apoptosis resistance and cell migration during cancer development. Wound healing and flow cytometry assays were performed to determine changes in cell motility, death and cell cycle in SCC cells. The results indicated that low levels of MXI could regulate the cell cycle, increase proliferation, and enhance tumor cell migration in HNSCC cell lines, but it might not contribute to apoptosis resistance. It also suggests that the level of $M X 1$ expression may be a predictor of metastatic potential in HNSCC. 


\section{REFERÊNCIAS BIBLIOGRÁFICAS}

Altschul, S. F., T. L. Madden, et al. (1997). "Gapped BLAST and PSI-BLAST: a new generation of protein database search programs." Nucleic Acids Res 25(17): 3389-402.

Ang, K. K., J. Harris, et al. (2010). "Human papillomavirus and survival of patients with oropharyngeal cancer." N Engl J Med 363(1): 24-35.

Argiris, A., M. V. Karamouzis, et al. (2008). "Head and neck cancer." Lancet 371(9625): 1695-709.

Bannister, A. J. and T. Kouzarides (2011). "Regulation of chromatin by histone modifications." Cell Res 21(3): 381-95.

Baylin, S. B., M. Esteller, et al. (2001). "Aberrant patterns of DNA methylation, chromatin formation and gene expression in cancer." Hum Mol Genet 10(7): 687-92.

Benedikt, A., S. Baltruschat, et al. (2011). "The leukemogenic AF4-MLL fusion protein causes P-TEFb kinase activation and altered epigenetic signatures." Leukemia 25(1): 135-44.

Bhardwaj, R. K., D. Herrera-Ruiz, et al. (2006). "The functional evaluation of human peptide/histidine transporter 1 (hPHT1) in transiently transfected COS-7 cells." Eur J Pharm Sci 27(5): 533-42.

Bird, A. (2002). "DNA methylation patterns and epigenetic memory." Genes Dev 16(1): 6-21.

Botka, C. W., T. W. Wittig, et al. (2000). "Human proton/oligopeptide transporter (POT) genes: identification of putative human genes using bioinformatics." AAPS PharmSci 2(2): E16. 
Boyes, J. and A. Bird (1992). "Repression of genes by DNA methylation depends on $\mathrm{CpG}$ density and promoter strength: evidence for involvement of a methyl-CpG binding protein." Embo J 11(1): 327-33.

Brasil. Ministério da Saúde, S. d. A. à. S. (2009). Estimativa 2010: Incidência de câncer no Brasil. I. 2009. Rio de Janeiro/RJ.

Bryan, J., E. Jabbour, et al. (2010). "Current and future management options for myelodysplastic syndromes." Drugs 70(11): 1381-94.

Califano, J., P. van der Riet, et al. (1996). "Genetic progression model for head and neck cancer: implications for field cancerization." Cancer Res 56(11): 2488-92.

Calmon, M. F., R. V. Rodrigues, et al. (2009). "Epigenetic silencing of CRABP2 and MX1 in head and neck tumors." Neoplasia 11(12): 1329-39.

Chen, M. W., K. T. Hua, et al. (2010). "H3K9 histone methyltransferase G9a promotes lung cancer invasion and metastasis by silencing the cell adhesion molecule EpCAM." Cancer Res 70(20): 7830-40.

Colella, S., L. Shen, et al. (2003). "Sensitive and quantitative universal Pyrosequencing methylation analysis of CpG sites." Biotechniques 35(1): 146-50.

Cooper, T. A., L. Wan, et al. (2009). "RNA and disease." Cell 136(4): 777-93.

Cork, D. M., T. W. Lennard, et al. (2008). "Alternative splicing and the progesterone receptor in breast cancer." Breast Cancer Res 10(3): 207.

Costa, F. F (2010). "Non-coding RNAs: Meet thy masters." Bioessays 32(7): 599-608.

Costa, R., H. Abdulhaq, et al. (2010). "Activity of azacitidine in chronic myelomonocytic leukemia." $\underline{\text { Cancer. }}$ 
Curado, M. P. and M. Hashibe (2009). "Recent changes in the epidemiology of head and neck cancer." Curr Opin Oncol 21(3): 194-200.

D'Souza, G., A. R. Kreimer, et al. (2007). "Case-control study of human papillomavirus and oropharyngeal cancer." N Engl J Med 356(19): 1944-56.

Daniel, H. and G. Kottra (2004). "The proton oligopeptide cotransporter family SLC15 in physiology and pharmacology." Pflugers Arch 447(5): 610-8.

Datta, J., K. Ghoshal, et al. (2009). "A new class of quinoline-based DNA hypomethylating agents reactivates tumor suppressor genes by blocking DNA methyltransferase 1 activity and inducing its degradation." Cancer Res 69(10): 4277-85.

de Camargo Cancela, M., L. Voti, et al. (2010). "Oral cavity cancer in developed and in developing countries: population-based incidence." Head Neck 32(3): 357-67.

Desmond, J. C., S. Raynaud, et al. (2007). "Discovery of epigenetically silenced genes in acute myeloid leukemias." Leukemia 21(5): 1026-34.

Diggle, M. A. and S. C. Clarke (2003). "A novel method for preparing single-stranded DNA for pyrosequencing." Mol Biotechnol 24(2): 221-4.

Egger, G., G. Liang, et al. (2004). "Epigenetics in human disease and prospects for epigenetic therapy." Nature 429(6990): 457-63.

Ellinger, J., P. Kahl, et al. (2010). "Prognostic relevance of global histone H3 lysine 4 (H3K4) methylation in renal cell carcinoma." Int J Cancer 127(10): 2360-6.

Esteller, M. (2007). "Cancer epigenomics: DNA methylomes and histone-modification maps." Nat Rev Genet 8(4): 286-98.

Esteller, M. and J. G. Herman (2002). "Cancer as an epigenetic disease: DNA methylation and chromatin alterations in human tumours." J Pathol 196(1): 1-7. 
Fang, J. Y., S. S. Zhu, et al. (1996). "Studies on the hypomethylation of c-myc, c-Ha-ras oncogenes and histopathological changes in human gastric carcinoma." $\underline{\mathrm{J}}$ Gastroenterol Hepatol 11(11): 1079-82.

Freedman, N. D., Y. Park, et al. (2008). "Fruit and vegetable intake and head and neck cancer risk in a large United States prospective cohort study." Int J Cancer 122(10): 2330-6.

Gallo, O. (1996). "Increasing evidence that Epstein-Barr virus may be involved in the pathogenesis of undifferentiated carcinoma of the salivary glands." $\underline{\text { Hum Pathol }}$ 27(12): 1381.

Gardiner-Garden, M. and M. Frommer (1987). "CpG islands in vertebrate genomes." J Mol Biol 196(2): 261-82.

Garinis, G. A., G. P. Patrinos, et al. (2002). "DNA hypermethylation: when tumour suppressor genes go silent." Hum Genet 111(2): 115-27.

Gaudet, F., J. G. Hodgson, et al. (2003). "Induction of tumors in mice by genomic hypomethylation." Science 300(5618): 489-92.

Goerner, M., T. Y. Seiwert, et al. (2010). "Molecular targeted therapies in head and neck cancer--an update of recent developments." Head Neck Oncol 2: 8.

Goldenberg, D., J. Lee, et al. (2004). "Habitual risk factors for head and neck cancer." Otolaryngol Head Neck Surg 131(6): 986-93.

Gonzalez, D. E., K. M. Covitz, et al. (1998). "An oligopeptide transporter is expressed at high levels in the pancreatic carcinoma cell lines AsPc-1 and Capan-2." Cancer Res 58(3): 519-25.

Ha, P. K. and J. A. Califano (2006). "Promoter methylation and inactivation of tumoursuppressor genes in oral squamous-cell carcinoma." Lancet Oncol 7(1): 77-82. 
Hagihara, A., K. Miyamoto, et al. (2004). "Identification of 27 5' CpG islands aberrantly methylated and 13 genes silenced in human pancreatic cancers." Oncogene 23(53): 8705-10.

Haller, O., P. Staeheli, et al. (2007). "Interferon-induced Mx proteins in antiviral host defense." Biochimie 89(6-7): 812-8.

Hanada, M., D. Delia, et al. (1993). "bcl-2 gene hypomethylation and high-level expression in B-cell chronic lymphocytic leukemia." Blood 82(6): 1820-8.

Hasegawa, M., H. H. Nelson, et al. (2002). "Patterns of gene promoter methylation in squamous cell cancer of the head and neck." Oncogene 21(27): 4231-6.

Hashibe, M., P. Boffetta, et al. (2006). "Evidence for an important role of alcohol- and aldehyde-metabolizing genes in cancers of the upper aerodigestive tract." $\underline{\text { Cancer }}$ Epidemiol Biomarkers Prev 15(4): 696-703.

Hashibe, M., P. Brennan, et al. (2009). "Interaction between tobacco and alcohol use and the risk of head and neck cancer: pooled analysis in the International Head and Neck Cancer Epidemiology Consortium." Cancer Epidemiol Biomarkers Prev 18(2): 541-50.

Hendrich, B. and A. Bird (2000). "Mammalian methyltransferases and methyl-CpGbinding domains: proteins involved in DNA methylation." Curr Top Microbiol Immunol 249: 55-74.

Herman, J. G., J. R. Graff, et al. (1996). "Methylation-specific PCR: a novel PCR assay for methylation status of CpG islands." Proc Natl Acad Sci U S A 93(18): 98216.

Herrera-Ruiz, D. and G. T. Knipp (2003). "Current perspectives on established and putative mammalian oligopeptide transporters." J Pharm Sci 92(4): 691-714. 
Herrera-Ruiz, D., Q. Wang, et al. (2001). "Spatial expression patterns of peptide transporters in the human and rat gastrointestinal tracts, Caco-2 in vitro cell culture model, and multiple human tissues." AAPS PharmSci 3(1): E9.

Hill, V. K., C. Ricketts, et al. (2011). "Genome-wide DNA methylation profiling of $\mathrm{CpG}$ islands in breast cancer identifies novel genes associated with tumorigenicity." Cancer Res.

Holzinger, D., C. Jorns, et al. (2007). "Induction of MxA gene expression by influenza A virus requires type I or type III interferon signaling." J Virol 81(14): 7776-85.

Horisberger, M. A., G. K. McMaster, et al. (1990). "Cloning and sequence analyses of cDNAs for interferon- and virus-induced human Mx proteins reveal that they contain putative guanine nucleotide-binding sites: functional study of the corresponding gene promoter." J Virol 64(3): 1171-81.

Hunter, K. D., E. K. Parkinson, et al. (2005). "Profiling early head and neck cancer." Nat Rev Cancer 5(2): 127-35.

IARC, W. G. o. t. E. o. C. R. t. H. (2007). "Human papillomaviruses." IARC Monogr Eval Carcinog Risks Hum 90: 1-636.

Issa, J. P., N. Ahuja, et al. (2001). "Accelerated age-related CpG island methylation in ulcerative colitis." Cancer Res 61(9): 3573-7.

Jaenisch, R. and A. Bird (2003). "Epigenetic regulation of gene expression: how the genome integrates intrinsic and environmental signals." Nat Genet 33 Suppl: 245-54.

Jemal, A., R. Siegel, et al. (2007). "Cancer statistics, 2007." CA Cancer J Clin 57(1): 43-66.

Jin, B., B. Yao, et al. (2009). "DNMT1 and DNMT3B modulate distinct polycombmediated histone modifications in colon cancer." Cancer Res 69(18): 7412-21. 
Jones, P. A. and S. B. Baylin (2002). "The fundamental role of epigenetic events in cancer." Nat Rev Genet 3(6): 415-28.

Jones, P. A. and P. W. Laird (1999). "Cancer epigenetics comes of age." Nat Genet 21(2): 163-7.

Jung, A. C., J. Briolat, et al. (2010). "Biological and clinical relevance of transcriptionally active human papillomavirus (HPV) infection in oropharynx squamous cell carcinoma." Int J Cancer 126(8): 1882-94.

Kaneda, A., T. Tsukamoto, et al. (2004). "Frequent hypomethylation in multiple promoter $\mathrm{CpG}$ islands is associated with global hypomethylation, but not with frequent promoter hypermethylation." Cancer Sci 95(1): 58-64.

Karamouzis, M. V., J. R. Grandis, et al. (2007). "Therapies directed against epidermal growth factor receptor in aerodigestive carcinomas." JAMA 298(1): 70-82.

Kochs, G. and O. Haller (1999). "Interferon-induced human MxA GTPase blocks nuclear import of Thogoto virus nucleocapsids." Proc Natl Acad Sci U S A 96(5): 2082-6.

Kresty, L. A., S. R. Mallery, et al. (2002). "Alterations of p16(INK4a) and p14(ARF) in patients with severe oral epithelial dysplasia." Cancer Res 62(18): 5295-300.

Kwong, J., K. W. Lo, et al. (2002). "Promoter hypermethylation of multiple genes in nasopharyngeal carcinoma." Clin Cancer Res 8(1): 131-7.

Leemans, C. R., B. J. Braakhuis, et al. (2011). "The molecular biology of head and neck cancer." Nat Rev Cancer 11(1): 9-22.

Li, E. (2002). "Chromatin modification and epigenetic reprogramming in mammalian development." Nat Rev Genet 3(9): 662-73.

Licatalosi, D. D., A. Mele, et al. (2008). "HITS-CLIP yields genome-wide insights into brain alternative RNA processing." Nature 456(7221): 464-9. 
Lingen, M., E. M. Sturgis, et al. (2001). "Squamous cell carcinoma of the head and neck in nonsmokers: clinical and biologic characteristics and implications for management." Curr Opin Oncol 13(3): 176-82.

Liu, W., R. Liang, et al. (1995). "Molecular cloning of PEPT 2, a new member of the $\mathrm{H}+/$ peptide cotransporter family, from human kidney." Biochim Biophys Acta 1235(2): 461-6.

Llewellyn, C. D., N. W. Johnson, et al. (2001). "Risk factors for squamous cell carcinoma of the oral cavity in young people--a comprehensive literature review." Oral Oncol 37(5): 401-18.

Lopez-Blanc, S. A., A. M. Collet, et al. (2009). "Nucleolar organizer regions (AgNOR) and subepithelial vascularization as field cancerization markers in oral mucosa biopsies of alcoholic and smoking patients." Oral Surg Oral Med Oral Pathol Oral Radiol Endod 108(5): 747-53.

Margueron, R. and D. Reinberg (2011). "The Polycomb complex PRC2 and its mark in life." Nature 469(7330): 343-9.

Martone, T., A. Gillio-Tos, et al. (2007). "Association between hypermethylated tumor and paired surgical margins in head and neck squamous cell carcinomas." $\underline{\text { Clin }}$ Cancer Res 13(17): 5089-94.

McMahon, S. and A. Y. Chen (2003). "Head and neck cancer." Cancer Metastasis Rev 22(1): 21-4.

Mibayashi, M., K. Nakad, et al. (2002). "Promoted cell death of cells expressing human MxA by influenza virus infection." Microbiol Immunol 46(1): 29-36.

Moriniere, S. (2006). "[Epidemiology of head and neck cancer]." Rev Prat 56(15): 1637-41. 
Mushinski, J. F., P. Nguyen, et al. (2009). "Inhibition of tumor cell motility by the interferon-inducible GTPase MxA." J Biol Chem 284(22): 15206-14.

Negri, E., P. Boffetta, et al. (2009). "Family history of cancer: pooled analysis in the International Head and Neck Cancer Epidemiology Consortium." Int J Cancer 124(2): 394-401.

Nguyen, C., G. Liang, et al. (2001). "Susceptibility of nonpromoter CpG islands to de novo methylation in normal and neoplastic cells." J Natl Cancer Inst 93(19): 1465-72.

Nordstrom, T., A. Alderborn, et al. (2002). "Method for one-step preparation of doublestranded DNA template applicable for use with Pyrosequencing technology." $\underline{\mathrm{J}}$ Biochem Biophys Methods 52(2): 71-82.

Nordstrom, T., K. Nourizad, et al. (2000). "Method enabling pyrosequencing on doublestranded DNA." Anal Biochem 282(2): 186-93.

Noser, J. A., A. A. Mael, et al. (2007). "The RAS/Raf1/MEK/ERK signaling pathway facilitates VSV-mediated oncolysis: implication for the defective interferon response in cancer cells." Mol Ther 15(8): 1531-6.

Ogi, K., M. Toyota, et al. (2002). "Aberrant methylation of multiple genes and clinicopathological features in oral squamous cell carcinoma." $\underline{\text { Clin Cancer Res }}$ 8(10): 3164-71.

Ogino, S., R. D. Odze, et al. (2006). "Correlation of pathologic features with CpG island methylator phenotype (CIMP) by quantitative DNA methylation analysis in colorectal carcinoma." Am J Surg Pathol 30(9): 1175-83.

Paluszczak, J., P. Misiak, et al. (2011). "Frequent hypermethylation of DAPK, RARbeta, MGMT, RASSF1A and FHIT in laryngeal squamous cell carcinomas and adjacent normal mucosa." Oral Oncol 47(2): 104-7. 
Pan, Q., O. Shai, et al. (2008). "Deep surveying of alternative splicing complexity in the human transcriptome by high-throughput sequencing." Nat Genet 40(12): 14135.

Park, Y. J., R. Claus, et al. (2011). "Genome-wide epigenetic modifications in cancer." Prog Drug Res 67: 25-49.

Parkin, D. M., F. Bray, et al. (2005). "Global cancer statistics, 2002." CA Cancer J Clin 55(2): 74-108.

Patel, S. C., W. R. Carpenter, et al. (2011). "Increasing Incidence of Oral Tongue Squamous Cell Carcinoma in Young White Women, Age 18 to 44 Years." J Clin Oncol.

Perez-Ordonez, B., M. Beauchemin, et al. (2006). "Molecular biology of squamous cell carcinoma of the head and neck." J Clin Pathol 59(5): 445-53.

Pfaffl, M. W. (2001). "A new mathematical model for relative quantification in realtime RT-PCR." Nucleic Acids Res 29(9): e45.

Poh, C. F., L. Zhang, et al. (2006). "Fluorescence visualization detection of field alterations in tumor margins of oral cancer patients." Clin Cancer Res 12(22): 6716-22.

Reichart, P. A. (2001). "Identification of risk groups for oral precancer and cancer and preventive measures." Clin Oral Investig 5(4): 207-13.

Reik, W., W. Dean, et al. (2001). "Epigenetic reprogramming in mammalian development." Science 293(5532): 1089-93.

Robertson, K. D. (2001). "DNA methylation, methyltransferases, and cancer." Oncogene 20(24): 3139-55.

Robertson, K. D. (2005). "DNA methylation and human disease." Nat Rev Genet 6(8): 597-610. 
Robertson, K. D. and A. P. Wolffe (2000). "DNA methylation in health and disease." Nat Rev Genet 1(1): 11-9.

Roblyer, D., C. Kurachi, et al. (2009). "Objective detection and delineation of oral neoplasia using autofluorescence imaging." Cancer Prev Res (Phila) 2(5): 42331.

Rodrigo, J. P., C. Suarez, et al. (2001). "Variability of genetic alterations in different sites of head and neck cancer." Laryngoscope 111(7): 1297-301.

Ronaghi, M., S. Karamohamed, et al. (1996). "Real-time DNA sequencing using detection of pyrophosphate release." Anal Biochem 242(1): 84-9.

Rosas, S. L., W. Koch, et al. (2001). "Promoter hypermethylation patterns of p16, O6methylguanine-DNA-methyltransferase, and death-associated protein kinase in tumors and saliva of head and neck cancer patients." Cancer Res 61(3): 939-42.

Sapkota, A., C. C. Hsu, et al. (2008). "Dietary risk factors for squamous cell carcinoma of the upper aerodigestive tract in central and eastern Europe." Cancer Causes Control 19(10): 1161-70.

Schulz, W. A., A. Alexa, et al. (2007). "Factor interaction analysis for chromosome 8 and DNA methylation alterations highlights innate immune response suppression and cytoskeletal changes in prostate cancer." Mol Cancer 6: 14.

Schwemmle, M., M. F. Richter, et al. (1995). "Unexpected structural requirements for GTPase activity of the interferon-induced MxA protein." J Biol Chem 270(22): 13518-23.

Shu, C., H. Shen, et al. (2001). "Mechanism of intestinal absorption and renal reabsorption of an orally active ace inhibitor: uptake and transport of fosinopril in cell cultures." Drug Metab Dispos 29(10): 1307-15. 
Silverman, L. R., E. P. Demakos, et al. (2002). "Randomized controlled trial of azacitidine in patients with the myelodysplastic syndrome: a study of the cancer and leukemia group B." J Clin Oncol 20(10): 2429-40.

Slaughter, D. P., H. W. Southwick, et al. (1953). "Field cancerization in oral stratified squamous epithelium; clinical implications of multicentric origin." $\underline{\text { Cancer }}$ 6(5): 963-8.

Smeets, S. J., R. H. Brakenhoff, et al. (2009). "Genetic classification of oral and oropharyngeal carcinomas identifies subgroups with a different prognosis." $\underline{\text { Cell }}$ Oncol 31(4): 291-300.

Smiraglia, D. J. and C. Plass (2003). "The development of CpG island methylation biomarkers using restriction landmark genomic scanning." Ann N Y Acad Sci 983: $110-9$.

Sneeringer, C. J., M. P. Scott, et al. (2010). "Coordinated activities of wild-type plus mutant EZH2 drive tumor-associated hypertrimethylation of lysine 27 on histone H3 (H3K27) in human B-cell lymphomas." Proc Natl Acad Sci U S A 107(49): 20980-5

Steiner, H. Y., F. Naider, et al. (1995). "The PTR family: a new group of peptide transporters." Mol Microbiol 16(5): 825-34.

Suarez, C., J. P. Rodrigo, et al. (2006). "Tumours of familial origin in the head and neck." Oral Oncol 42(10): 965-78.

Sultan, M., M. H. Schulz, et al. (2008). "A global view of gene activity and alternative splicing by deep sequencing of the human transcriptome." Science 321(5891): 956-60.

Suzuki, M. M. and A. Bird (2008). "DNA methylation landscapes: provocative insights from epigenomics." Nat Rev Genet 9(6): 465-76. 
Syrjanen, S. (2005). "Human papillomavirus (HPV) in head and neck cancer." J Clin Virol 32 Suppl 1: S59-66.

Tazi, J., N. Bakkour, et al. (2009). "Alternative splicing and disease." Biochim Biophys Acta 1792(1): 14-26.

Terada, T., K. Sawada, et al. (2000). "Inhibitory effect of novel oral hypoglycemic agent nateglinide (AY4166) on peptide transporters PEPT1 and PEPT2." Eur J Pharmacol 392(1-2): 11-7.

Testoni, B., V. Schinzari, et al. (2011). "p53-paralog DNp73 oncogene is repressed by IFNalpha/STAT2 through the recruitment of the Ezh2 polycomb group transcriptional repressor." Oncogene.

Tyler, J. K. and J. T. Kadonaga (1999). "The "dark side" of chromatin remodeling: repressive effects on transcription." Cell 99(5): 443-6.

Ushijima, T. (2005). "Detection and interpretation of altered methylation patterns in cancer cells." Nat Rev Cancer 5(3): 223-31.

Verma, M. and S. Srivastava (2002). "Epigenetics in cancer: implications for early detection and prevention." Lancet Oncol 3(12): 755-63.

Villar-Garea, A., M. F. Fraga, et al. (2003). "Procaine is a DNA-demethylating agent with growth-inhibitory effects in human cancer cells." Cancer Res 63(16): 49849.

Vire, E., C. Brenner, et al. (2006). "The Polycomb group protein EZH2 directly controls DNA methylation." Nature 439(7078): 871-4.

Wade, P. A. (2001). "Methyl CpG-binding proteins and transcriptional repression." Bioessays 23(12): 1131-7.

Walker, D., D. T. Thwaites, et al. (1998). "Substrate upregulation of the human small intestinal peptide transporter, hPepT1." J Physiol 507 ( Pt 3): 697-706. 
Wang, E. T., R. Sandberg, et al. (2008). "Alternative isoform regulation in human tissue transcriptomes." Nature 456(7221): 470-6.

Wang, Y. and F. C. Leung (2004). "An evaluation of new criteria for CpG islands in the human genome as gene markers." Bioinformatics 20(7): 1170-7.

Watanabe, K., T. Sawano, et al. (2002). "Studies on intestinal absorption of sulpiride (1): carrier-mediated uptake of sulpiride in the human intestinal cell line Caco2." Biol Pharm Bull 25(7): 885-90.

Wenzel, U., S. Kuntz, et al. (2002). "PEPT1-mediated cefixime uptake into human intestinal epithelial cells is increased by $\mathrm{Ca} 2+$ channel blockers." $\underline{\text { Antimicrob }}$ Agents Chemother 46(5): 1375-80.

Winquist, E., J. Knox, et al. (2006). "Phase II trial of DNA methyltransferase 1 inhibition with the antisense oligonucleotide MG98 in patients with metastatic renal carcinoma: a National Cancer Institute of Canada Clinical Trials Group investigational new drug study." Invest New Drugs 24(2): 159-67.

Wong, C. M., C. C. Wong, et al. (2011). "Transcriptional Repressive H3K9 and H3K27 Methylations Contribute to DNMT1-Mediated DNA Methylation Recovery." PLoS One 6(2): e16702.

Wong, N. A., M. P. Britton, et al. (2004). "Loss of CDX1 expression in colorectal carcinoma: promoter methylation, mutation, and loss of heterozygosity analyses of 37 cell lines." Proc Natl Acad Sci U S A 101(2): 574-9.

Worsham, M. J., K. M. Chen, et al. (2006). "Epigenetic events of disease progression in head and neck squamous cell carcinoma." Arch Otolaryngol Head Neck Surg 132(6): 668-77.

Wulfkuhle, J. D., C. P. Paweletz, et al. (2003). "Proteomic approaches to the diagnosis, treatment, and monitoring of cancer." Adv Exp Med Biol 532: 59-68. 
Yamashita, T., S. Shimada, et al. (1997). "Cloning and functional expression of a brain peptide/histidine transporter." J Biol Chem 272(15): 10205-11.

Yang, X., T. J. Tschaplinski, et al. (2011). "Discovery and annotation of small proteins using genomics, proteomics, and computational approaches." Genome Res.

Yoder, J. A., C. P. Walsh, et al. (1997). "Cytosine methylation and the ecology of intragenomic parasites." Trends Genet 13(8): 335-40. 


\section{CAPÍTULO 4}

\section{INTRODUÇÃO}

O carcinoma epidermóide de cabeça e pescoço (CECP) está entre as mais frequentes neoplasias em humanos. Esta doença afeta principalmente homens e tem como principal fator etiológico o consumo crônico de álcool e tabaco. A taxa de sobrevida em cinco anos é uma das mais baixas quando comparada à de outras neoplasias, permanecendo praticamente inalterada ao longo das últimas décadas.

Esses tumores possuem prognóstico favorável quando detectados precocemente mas, nas fases iniciais da doença, os pacientes apresentam poucos sintomas. A maioria destes tumores é diagnosticado tardiamente, quando muitos possuem metástases. Não há dúvidas, portanto, de que marcadores de diagnóstico e prognóstico são particularmente importantes para o carcinoma epidermóide de cabeça e pescoço.

Várias técnicas de análise de expressão gênica global têm fornecido uma lista crescente de biomarcadores potenciais. Entre essas técnicas, estão a de microarranjos de cDNA e de análise serial de expressão gênica (SAGE - do inglês, Serial Analysis of Gene Expression), ambas capazes de avaliar a expressão de milhares de genes simultaneamente. No entanto, poucos destes genes têm sido utilizados efetivamente na prática clínica ou como alvos terapêuticos.

\section{MATERIAIS E MÉTODOS}

Com o objetivo de identificar genes envolvidos no desenvolvimento e na progressão de carcinomas epidermóides de laringe, foi realizada a análise de expressão gênica diferencial por meio do método de SAGE. Para tanto, foram construídas duas bibliotecas, uma a partir de tumor com metástase em linfonodos regionais $(\mathrm{N}+)$ e outra de tumor sem evidência de metástases (N0), além de uma biblioteca gerada de um pool de duas amostras de mucosa normal de laringe. Dentre os genes que apresentaram expressão diferencial nos experimentos de SAGE, foram selecionados quatro para validação por PCR em tempo real. Tais validações foram realizadas em um conjunto de 26 amostras de tumores primários de laringe ( $15 \mathrm{~N} 0$ and $11 \mathrm{~N}+)$ e em 36 amostras de tumores primários de língua (18 N0 and $18 \mathrm{N+}$ ), além de dois pools de margens cirúrgicas normais de laringe e língua. 


\section{RESULTADOS E DISCUSSÃO}

O sequenciamento do material obtido a partir das três bibliotecas SAGE gerou aproximadamente 54 mil tags únicas. As análises estatísticas identificaram um conjunto de 1.216 tags com expressão diferencial entre as bibliotecas de tumores e amostras normais e 894 tags entre carcinomas metastáticos e não metastáticos. Três genes que apresentaram expressão diferencial entre tumores e amostras normais foram selecionados para validações por PCR em amostras de CECP: um deles com expressão reduzida $(K R T 31)$ e dois outros com expressão aumentada (BST2, MFAP2). Além desses, um quarto gene (GNA15) sem diferenças significativas de expressão em relação ao tecido normal foi escolhido como controle negativo.

Os resultados dos experimentos por PCR em tempo real foram consistentes com as análises estatísticas dos dados de SAGE. Estes resultados confirmaram a expressão elevada dos transcritos BST2 e MFAP2 e diminuída no caso de KRT31 nas amostras de $\mathrm{CECP}$ em relação às margens cirúrgicas normais. Como esperado, o gene GNA15 não mostrou diferenças significativas de expressão em tumores, quando comparados com amostras normais.

Este estudo foi o primeiro a utilizar a metodologia de SAGE em amostras de CECP que, após o tratamento estatístico empregado, mostrou-se efetiva na identificação de genes diferencialmente expressos e potencialmente envolvidos no desenvolvimento do câncer. Os dados gerados por este trabalho sugerem a existência de um conjunto de biomarcadores potenciais para prognóstico e de possíveis alvos para o desenvolvimento de terapias específicas para esse tipo de tumor. 


\section{Searching for molecular markers in head and neck squamous cell carcinomas (HNSCC) by statistical and bioinformatic analysis of larynx-derived SAGE libraries}

Nelson JF Silveira ${ }^{\dagger 1}$, Leonardo Varuzza ${ }^{\dagger 2}$, Ariane Machado-Lima ${ }^{3}$,

Marcelo S Lauretto ${ }^{2}$, Daniel G Pinheiro ${ }^{4}$, Rodrigo V Rodrigues ${ }^{5,6}$,

Patrícia Severino7, Francisco G Nobrega ${ }^{8}$, Head and Neck Genome Project

GENCAPO ${ }^{9}$, Wilson A Silva $\mathrm{Jr}^{4}$, Carlos A de B Pereira*2 and

Eloiza H Tajara*5,6

Address: ${ }^{1}$ Instituto de Pesquisa e Desenvolvimento, Universidade do Vale do Paraíba, UNIVAP, São José dos Campos, SP, Brazil, ${ }^{2}$ Instituto de Matemática e Estatística, USP, São Paulo, SP, Brazil, ${ }^{3}$ BIOINFO-USP Núcleo de Pesquisas em Bioinformática, USP, SP, Brazil, ${ }^{4}$ Departamento de Genética, Faculdade de Medicina de Ribeirão Preto-USP, Centro de Terapia Celular, Centro Regional de Hemoterapia, SP, Brazil, ${ }^{5}$ Departamento de Biologia Molecular, Faculdade de Medicina de São José do Rio Preto, FAMERP, São José do Rio Preto, SP, Brazil, "6epartamento de Genética e Biologia Evolutiva, Instituto de Biociências, USP, São Paulo, SP, Brazil, 7Instituto de Ensino e Pesquisa Albert Einstein, São Paulo, SP, Brazil, ${ }^{8}$ Departamento de Biociências e Diagnóstico Bucal, Faculdade de Odontologia, UNESP, São José dos Campos, SP, Brazil and ${ }^{9}$ Complete authors list and addresses is presented in the Appendix

Email: Nelson JF Silveira - nelsonjfs@univap.br; Leonardo Varuzza - varuzza@gmail.com; Ariane Machado-Lima - ariane.machado@gmail.com; Marcelo S Lauretto - marcelo.lauretto@gmail.com; Daniel G Pinheiro - dgpinheiro@gmail.com; Rodrigo V Rodrigues - rvieira@ib.usp.br; Patrícia Severino - psever@einstein.br; Francisco G Nobrega - fgdnobre@univap.br; Head and Neck Genome Project

GENCAPO - gencapo@yahoogrupos.com.br; Wilson A Silva - wilsonjr@usp.br; Carlos A de B Pereira* - cadebp@gmail.com;

Eloiza H Tajara* - tajara@famerp.br

* Corresponding authors †Equal contributors

\footnotetext{
Abstract

Background: Head and neck squamous cell carcinoma (HNSCC) is one of the most common malignancies in humans. The average 5-year survival rate is one of the lowest among aggressive cancers, showing no significant improvement in recent years. When detected early, HNSCC has a good prognosis, but most patients present metastatic disease at the time of diagnosis, which significantly reduces survival rate. Despite extensive research, no molecular markers are currently available for diagnostic or prognostic purposes.

Methods: Aiming to identify differentially-expressed genes involved in laryngeal squamous cell carcinoma (LSCC) development and progression, we generated individual Serial Analysis of Gene Expression (SAGE) libraries from a metastatic and non-metastatic larynx carcinoma, as well as from a normal larynx mucosa sample. Approximately 54,000 unique tags were sequenced in three libraries.

Results: Statistical data analysis identified a subset of 1,216 differentially expressed tags between tumor and normal libraries, and 894 differentially expressed tags between metastatic and nonmetastatic carcinomas. Three genes displaying differential regulation, one down-regulated (KRT3I) and two up-regulated (BST2, MFAP2), as well as one with a non-significant differential expression
} 


\begin{abstract}
pattern (GNA/5) in our SAGE data were selected for real-time polymerase chain reaction (PCR) in a set of HNSCC samples. Consistent with our statistical analysis, quantitative PCR confirmed the upregulation of BST2 and MFAP2 and the downregulation of KRT3I when samples of HNSCC were compared to tumor-free surgical margins. As expected, GNA/5 presented a non-significant differential expression pattern when tumor samples were compared to normal tissues.

Conclusion: To the best of our knowledge, this is the first study reporting SAGE data in head and neck squamous cell tumors. Statistical analysis was effective in identifying differentially expressed genes reportedly involved in cancer development. The differential expression of a subset of genes was confirmed in additional larynx carcinoma samples and in carcinomas from a distinct head and neck subsite. This result suggests the existence of potential common biomarkers for prognosis and targeted-therapy development in this heterogeneous type of tumor.
\end{abstract}

\section{Background}

Head and neck squamous cell carcinoma (HNSCC) is one of the most common malignancies in humans, affecting distinct head and neck topologies including oral cavity, oropharynx, hypopharynx, larynx and nasopharynx. HNSCC is associated with high alcohol and tobacco consumption, and represents a major international health problem with approximately 650,000 cases and 90,000 deaths per year worldwide [1]. In Brazil, over 13,000 new cases are expected in 2008 [2]. Currently, advances in both surgical and nonsurgical therapeutics have led to increased local tumor control. However, overall mortality rates have not improved due to tumor recurrences in regional and distant sites of the aerodigestive tract [3]. When detected early, HNSCC has a 75\% 5-year survival rate, but most patients present metastatic disease at the time of diagnosis, which reduces survival rate to $35 \%$ [4]. This 5 -year survival rate is one of the lowest among aggressive cancers and has shown no significant improvement in recent years $[5,6]$.

Currently, there are very few molecular markers that can be used with accuracy and reliability as indicators of head and neck carcinomas with potential for metastatic progression, and therefore as indicators of a more aggressive tumor behavior. A pre-operative marker, for example, could significantly help in determining the most appropriate treatment for a particular patient [7]. Moreover, changes in the gene expression profile arising exclusively or preferentially in cancer can be used as molecular markers [8]. In fact, these markers may provide us with new means for the early detection of cancer and cancer risk assessment, as discussed by Hunter et al. (2005) [9] for HNSCC.

In order to investigate molecular markers that may be relevant for prognosis and therapy in cancer disease, largescale transcriptomic approaches such as SAGE and microarrays have been extensively reported in the literature [1012]. In the present study, we decided to use SAGE since this technique allows an unbiased global view of all the transcripts expressed in a tissue sample at a given time point. Despite its appropriateness for such studies, SAGE is an expensive and complex technique, thus commonly involving few and often rare biological samples.

We generated individual SAGE libraries from metastatic $(\mathrm{N}+)$ and non-metastatic (NO) larynx carcinomas, and from normal mucosa samples. A database was created to provide absolute frequency tags for each gene in metastatic and non-metastatic tumors, and for the normal tissues. For the statistical analysis of differentially expressed tags, the Poisson distribution was used as the basic probabilistic model. The Cox partial likelihood combined with Dempster p-values allowed us to consider an efficient significance test to compare the Poisson means of the three groups. Also, the choice of critical level depended on the expression power of the tag been tested. The analysis of the data by our statistical approach revealed subsets of differentially expressed genes between tumor and normal tissues, and between metastatic and non-metastatic carcinomas. These differentially expressed genes deserve further consideration as potential biomarkers for metastatic progression, and therefore as indicators of a more aggressive tumor behavior.

\section{Methods}

\section{Sample preparation for SAGE and real time PCR} experiments

Samples were frozen in liquid nitrogen and stored at $80^{\circ} \mathrm{C}$. Total RNA was extracted using TRIzol Reagent and treated with DNase (Invitrogen Corporation, Carlsbad, CA, USA). CDNA synthesis was performed using the High Capacity cDNA Archive kit (Applied Biosystems, Forster City, CA, USA) as described by the manufacturer.

The study protocol was approved by the National Committee of Ethics in Research (CONEP 1763/05, 18/05/ 2005) and informed consent was obtained from all patients enrolled. 


\section{SAGE}

SAGE was carried out using the I-SAGE ${ }^{\mathrm{ru}}$ Kit (Invitrogen Corporation, Carlsbad, CA, USA). Briefly, mRNA was captured from total RNA by binding to oligo (dT) magnetic beads, and reverse transcribed with SuperScript ${ }^{\mathrm{TM}}$ II reverse transcriptase and E. coli DNA polymerase. Bound CDNA was cleaved with Nla III (anchoring enzyme), divided in two fractions and ligated to adapters A and B, both containing a $B s m F$ I restriction site followed by a CATG 3 'overhang, with different primer anchoring sequences at the 5 'end. Adapter linked cDNA from both fractions were cleaved with BsmF I (tagging enzyme) to generate adapter linked tags that were filled in by Klenow polymerase and then mixed and ligated to form adapter linked ditags. This mixture was used as template, in three 96-well $50 \mu \mathrm{l} \mathrm{PCR}$ reactions using primers complementary to the adapters, and the 100-bp products were PAGE purified. Adapters were eliminated by digestion with Nla III and PAGE purification of the $26 \mathrm{bp}$ ditags that were ligated to form concatamers. Concatamers were submitted to polyacrylamide gel electrophoresis and regions ranging from $300-500 \mathrm{bp}$, $500-800$ bp and $800-1000$ bp were purified and ligated to pZero $^{-1}$ cloning vector. Ligation reactions were used to transform One Shot ${ }^{\circledR}$ TOP10 Eletrocomp ${ }^{\mathrm{TM}}$ E. coli cells using $0.2 \mathrm{~cm}$ cuvettes and a Gene Pulser II electroporator (Bio-Rad Laboratories, Hercules, CA, USA) set at $2.5 \mathrm{kV}$, $25 \mathrm{mF}$ and $200 \Omega$. Cells were plated on low salt LB agar containing Zeocin ${ }^{*}$, in plates compatible with the automated colony picker QPix2 (Genetix, New Milton, Hampshire, UK). Picked colonies were grown separately on 96well plates containing 2XYT media. An aliquot of each well was then used directly in a PCR reaction, with forward and reverse M13 primers. Amplified inserts were checked and sequenced with forward M13 primer in a MegaBACE ${ }^{\mathrm{TM}} 1000$ sequencer (Amersham Biosciences, Piscataway, NJ, USA) and the DYEnamic ET Dye Terminator Sequencing Kit (Amersham Biosciences, Piscataway, NJ, USA), or alternatively, an ABI PRISM 377 DNA Sequencer (Applied Biosystems, Foster City, CA) and the ABI PRISM ${ }^{*}$ BigDye $^{\mathrm{Tn}}$ Primer Cycle Sequencing Kit (Applied Biosystems, Foster City, CA, USA).

Three SAGE libraries were generated using two larynx cancer samples (one with lymph node metastasis or $\mathrm{N}+$ and one with no lymph node metastasis or $\mathrm{NO}$ ) and a normal control library pooled from two normal samples (surgical margins from one $\mathrm{N}+$ and one N0 larynx cancer). For each library, 6,000 sequencing reactions were performed and tags were extracted to yield approximately 100,000 tags per library.

The raw data files are available at the Gene Expression Omnibus database (GEO) under the accession numbers: GSM303325 (pool of normal samples); GSM303340 (NO tumor), GSM303349 ( $\mathrm{N}+$ tumor).

\section{SAGE database}

Tag frequency tables, composed of a "tag" column (10 bp sequences) and a "count" column (number of times that the tag appears in the library) were obtained by the SAGE $^{\mathrm{rm}}$ Analysis 2000 Software 4.0, with minimum tag count set to 1 and maximum di-tag length set to $28 \mathrm{bp}$, whereas other parameters were set on default. A relational MySQL database [13] was developed to store data from SAGE experiments. The datasets contained information on: gene name, accession number, UniGene code, gene symbol, absolute frequency tags in metastatic and nonmetastatic tumors and normal tissues. Other tables were generated to store information on metabolic pathways and gene ontology. Scripts developed in Perl [14] integrated with the MySQL database allowed the identification of genes and their respective frequencies in the three libraries which were used as input data in the program that performed statistical analysis. A schematic representation of databases, data analysis, and experimental validation representing our approach is shown in Figure 1.

\section{Statistical Method}

Before starting the statistical analysis, we decided to exclude very low expression tags from the study. The inclusion criterion considered only tags with total normalized frequencies larger than 3 . In order to obtain normalized frequencies, the absolute frequencies in each library were divided by the total number of tags of this library and multiplied by the total number of tags of the smallest library. For each tag, we observed the sum of its three normalized frequencies. If this sum was larger than 3 , it was kept in the study; otherwise, it was excluded. The remaining tags, after this exclusion procedure, are the object of our study (Additional file 1, Supplementary Table 1).

Returning to the absolute frequencies of the remaining tags, we observed that all frequencies were low in relation to the size of the libraries. In such rare cases, the Poisson distribution is the adequate statistical model for the analysis. In fact, the three absolute frequencies for each tag are considered independent Poisson distributed variables. The statistical objective at this point, for a specific tag, is to decide whether there are differences in expression among the libraries. We should perform statistical tests for every tag in the data bank.

Comparing Poisson distribution is not an easy task. We then used the Partial Likelihood method as developed by Cox (1975) [15]. Briefly, the procedure considers the three frequencies of a specific tag as forming an observation of a trinomial distribution, where the sample size is now the total tag abundance, $\mathrm{S}$. Representing now the unknown trinomial probabilities of a specific tag by $\left(p_{1}\right.$, $\left.p_{2}, p_{3}\right)$ and the total library sizes by $\left(N_{1}, N_{2}, N_{3}\right)$, homoge- 


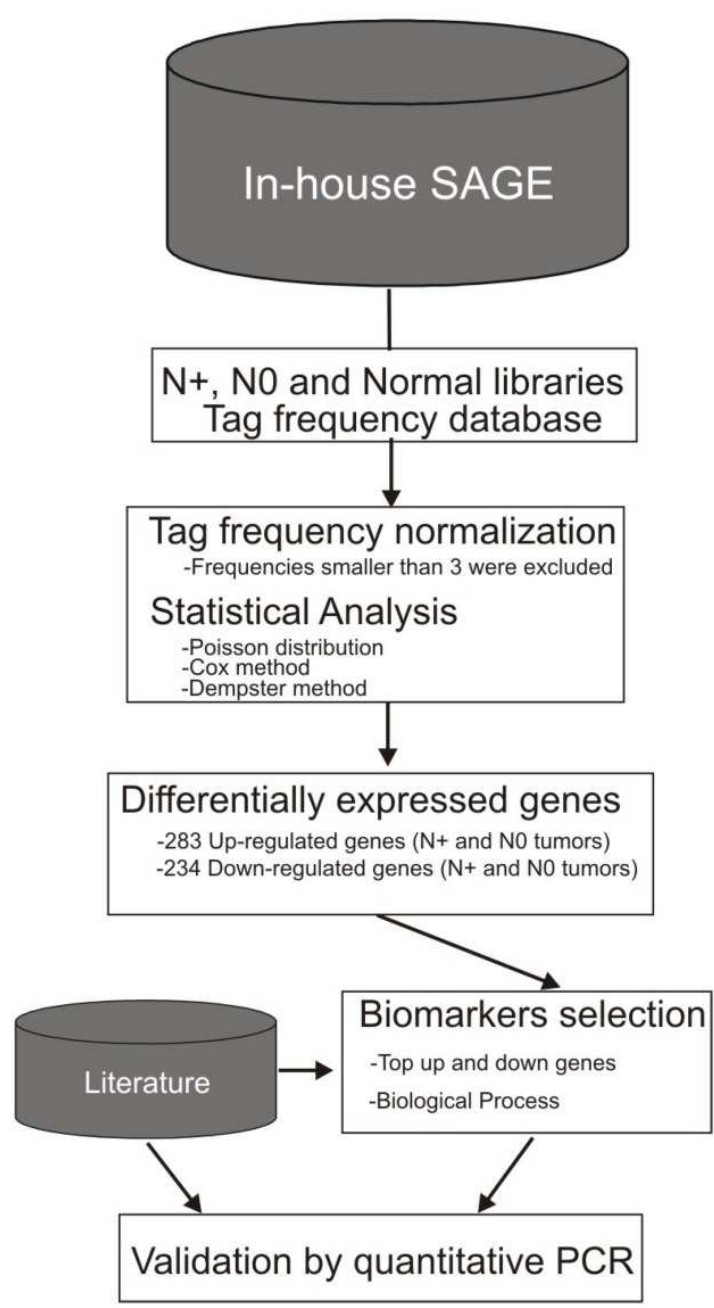

Figure I

Fluxogram showing the strategy used in SAGE data analysis.

neity among the original three Poisson averages can be tested by testing, in the trinomial model, the hypothesis

$$
\mathrm{H}:\left(p_{1}, p_{2}, p_{3}\right)=\left(N_{1}, N_{2}, N_{3}\right) / \mathrm{N} \text { where } \mathbf{N}=N_{1}+N_{2}+N_{3} \text {. }
$$

Again, we have a difficult task to compute a $p$-value in a tri-dimensional sample space. Since we have distinct tag abundances, which can go from 4 to more than one thousand tags, we have to be very precise in defining the p-values. For this task, we decided to use the method developed by Dempster (1997) [16]. The method consists of ordering the sample space by the likelihood ratios. To compute the p-value, the tail area was considered as the set of all points that have likelihood ratios smaller than those of the observed frequencies.

Finally, as mentioned before, the tag abundances can be very different, and considering the same significance level would be inappropriate for the tags with low frequencies. Following the recommendations of DeGroot (1975) [17], we used the decision theory optimum procedure that minimizes the risk function $\mathbf{a} \alpha+\mathbf{b} \beta$. Here, $\alpha$ and $\beta$ are the first and second kind of errors. In our case, we decided to choose $\mathbf{a}=4$ and $\mathrm{b}=1$ since we believe that the first type of error (deciding in favor of differentially expressed when it is not) is more dangerous than the second type of error (deciding against differentially expressed when it is). Using simulated samples, we found that the level of significance is a function of S, the tag abundance: $\alpha=0.07 \mathrm{~S}$ $1 / 2$.

A detailed description of the statistical method is presented in Varuzza and Pereira (2008) [18].

\section{Functional classification of differentially expressed genes and online gene expression analysis}

Gene ontology (GO) annotation was used for the functional classification of up- and down-regulated genes. This task was performed using terms from the Gene Ontology database [19].

Additionally, we used the Oncomine database [20] in order to search for a previous association of differentially expressed genes found in this study with head and neck cancer.

\section{Real Time PCR}

Three genes displaying down (KRT31) or upregulation (BST2, MFAP2) were selected for validation in additional tissues using real-time polymerase chain reaction. One gene (GNA15) that did not present differential expression was also selected for this validation. Their expression was checked in 26 larynx SCC samples ( $15 \mathrm{NO}$ and $11 \mathrm{~N}+$ ) relative to matched normal samples and in 36 tongue SCC samples ( $18 \mathrm{~N} 0$ and $18 \mathrm{~N}+$ ). The primers were manually designed using the following parameters: $19-23$ bp length, 30-70\% GC content, a short amplicon size (66$110 \mathrm{bp}$ ), and at least one primer of each pair flanking an intron-exon boundary to prevent genomic amplification (Table 1). All primers were purchased from Invitrogen (Brazil).

Real time PCR was carried out in a 7500 Real-Time PCR System (Applied Biosystems). Reactions were performed in $20 \mu \mathrm{l}$ with $10 \mu \mathrm{l}$ of Power SYBR ${ }^{\star}$ Green PCR Master Mix (Applied Biosystems), and $400 \mathrm{nM}$ of each primer. For every experiment, 10 ng cDNA were used, and each sam- 
Table I: Primers for real time PCR, amplicon size, values of slope, PCR efficiency and linearity (R2).

\begin{tabular}{|c|c|c|c|c|c|c|}
\hline Genes & Primers & $5^{\prime} \rightarrow 3^{\prime}$ & Amplicon size (bp) & Slope & PCR Efficiency & $\mathbf{R 2}$ \\
\hline \multirow[t]{2}{*}{ GNAI5 } & Forward & GAGAACCGCATGAAGGAGAG & 84 & -3.312 & 100.0 & 0.991 \\
\hline & Reverse & AAAGAGGATGACGGATGTGC & & & & \\
\hline \multirow[t]{2}{*}{ KRT3। } & Forward & TGAGCAGGAGGTCAATACCC & 110 & -2.913 & 120.4 & 0.990 \\
\hline & Reverse & GACTCCTGGTCTCGTTCAGC & & & & \\
\hline \multirow[t]{2}{*}{ BST2 } & Forward & GGAGGAGCTTGAGGGAGAG & 75 & -3.476 & 93.9 & 0.991 \\
\hline & Reverse & CTCAGTCGCTCCACCTCTG & & & & \\
\hline \multirow[t]{2}{*}{ MFAP2 } & Forward & GCCGTGAGGAACAGTACCC & 91 & -3.152 & 107.6 & 0.990 \\
\hline & Reverse & CGGAGGCTGTAGAAGCAGAC & & & & \\
\hline \multirow[t]{2}{*}{ TUBA6 } & Forward & TCAACACCTTCTTCAGTGAAACG & 101 & -3.341 & 99.2 & 0.991 \\
\hline & Reverse & AGTGCCAGTGCGAACTTCATC & & & & \\
\hline \multirow[t]{2}{*}{ GAPDH } & Forward & ACССАСТССТССАССТTTGA & 101 & -3.392 & 97.1 & 0.990 \\
\hline & Reverse & CTGTTGCTGTAGCCAAATTCGT & & & & \\
\hline \multirow[t]{2}{*}{ ACTB } & Forward & GGCACCCAGCACAATGAAG & 66 & -3.255 & 102.8 & 0.994 \\
\hline & Reverse & CCGATCCACACGGAGTACTTG & & & & \\
\hline
\end{tabular}

ple was tested in triplicate. The PCR conditions were $50^{\circ} \mathrm{C}$ for $2 \mathrm{~min}, 95^{\circ} \mathrm{C}$ for $10 \mathrm{~min}$ followed by 40 cycles at $95^{\circ}$ for $15 \mathrm{sec}, 60^{\circ} \mathrm{C}$ for $1 \mathrm{~min}, 65^{\circ} \mathrm{C}$ for $34 \mathrm{sec}$. Following the PCR, dissociation curve analysis was performed to confirm the desired single gene product.

For each primer set, the efficiency of the PCR reaction (linear equation: $\mathrm{y}=$ slope + intercept) was measured in triplicate on serial dilutions of the same cDNA sample (a pool of 10 samples).

The PCR efficiency (E) was calculated by the formula $E=$ $\left[10^{(-1 / \text { slope })}\right]$ and ranged from 1.96 to 2.02 in the different assays. The slope and $R 2$ values for target and reference genes are shown in Table 1.

Initially, five control genes were used (TUBA6, АCTB, GAPDH, BCR, HPRT). The GeNorm program [21] calculated stability and assumed that three genes (TUBAG, ACTB, GAPDH) were the most appropriate.

The relative expression ratio (fold change) of the target genes was calculated according to Pfaffl (2001) [22]. Sta- tistical analysis was calculated by a two-tailed unpaired $t$ test using GraphPad prism software.

\section{Results and discussion}

Statistical analysis of SAGE data

We constructed three SAGE libraries from two larynx carcinoma samples and a pooled control sample aiming to identify global events involved in tumorigenesis and potential biomarkers in HNSCC.

Given the huge amount of data generated by SAGE, events that play a consistent role in cancer phenotype may be undistinguished from those that are random events, leading to false positive and false negative results. Statistical analysis and bioinformatic tools are used to overcome these limitations and improve the identification of a gene expression signature of biological and therapeutic interest. In the present study, we propose a statistical approach to analyze SAGE data through the use of Poisson probabilistic model and the conditional test of Cox partial likelihood. A Dempster methodology for ordering the sample points of the sample spaces throughout the likelihood ratio was also considered to compute the p-values. As the 
sample size differs considerably, we obtain the significance critical level as a function of the tag abundance. To order the differentially expressed genes we consider the relative distance of the p-values against the critical level.

A total of 53,898 SAGE unique tags were obtained: 8,979 were only found in the metastatic larynx carcinoma library, 17,588 only in the non-metastatic carcinoma library, 15,102 only in the control library, and 12,229 tags were expressed in at least two libraries (Additional file 1, Tables 2, 3, 4-5). The sequences were stored in a MySQL relational database and analyzed as shown in Figure 1. Statistical analysis identified subsets of 1,216 differentially expressed tags between tumor and normal libraries, and 894 differentially expressed tags between metastatic and non-metastatic carcinomas. Sixty top-up and 60 topdownregulated tags in aggressive versus non-aggressive tumors and in both these tumors versus normal tissues, as well as their normalized frequencies, and the corresponding genes according to SAGE Genie and SAGEmap databases $[23,24]$ are presented in Supplementary Tables $6-11$ (Additional file 2).

Since several authors have reported that chi-square test is the most appropriate for SAGE experiments [25-28], we compared the performance of our statistical approach (named here as Kemp method) with that of chi-square test. For this comparison, the SAGE data set was divided into two groups: the low-abundance tags with counts equal and lower than 50, and the high abundance tags expressed at higher levels $(>50)$. Good correspondence between the data obtained by both tests was found for the latter tag group (Figure 2), indicating that they are equivalent for the analysis of highly expressed sequences. A similar result was not observed for low-abundance tags (Figure 3).

Using a proposed tag-customized critical level for both tests, we found 341 discordant tags, which represent $4.8 \%$ of total differentially expressed tags: $100(29.3 \%)$ were considered differentially expressed by chi-square test but not by Kemp method, and $241(70.7 \%)$ by Kemp but not by chi-square test. Most discordant cases were low-abundance tags (Additional file 3 ).

A tag presenting a differential expression pattern but low counts may be considered as statistically non-significant by methods that use fixed critical levels. Although a number of these tags probably have biological relevance, their selection from the SAGE data sets remains a challenge. To circumvent this limitation, Kemp's method calculates the critical level of each particular tag taking into account its total frequency, thus making the method applicable for detecting differences in expression of tags with counts ranging from 20 to 50 . In addition, the use of a tag-customized critical level minimizes both type I and type II errors. Conversely, most of the statistical tests currently used to detect differentially expressed genes are based on asymptotic results, and perform poorly for low expression tags. Another feature of these tests is the common use of a single canonical cutoff for the significance level (p-value) of all tags, without taking into account the type II error.

\section{Differentially expressed genes: biological functions and} potential involvement in HNSCC

Information on biological processes was obtained from the Gene Ontology (GO) database [19] for the top upand down-regulated genes identified by the statistical approach (Tables 2 and 3 ). The data may be helpful for evaluating their potential as drug targets and molecular markers of cancer. Although some GO terms are not directly related to tumorigenesis, as lipid metabolism process and viral genome replication, they provide evidence of some important changes in cell metabolism coupled to energy generation and cell growth [29].

The functions of up-regulated genes in tumors include signal transduction (BST2, FLNB, GNAI2), transcription (NRG1), anti-apoptosis (ANGPTL4, CCL2, IFI6), cell adhesion (SAA1), cell migration and angiogenesis (MYH9), epidermis development and keratinization (COL1A1, COL7A1, KRT14, LAMC2, S100A7), and proteolysis (MYH9). Down-regulated genes are also involved in signaling (CD24, DBNL, ECM1, TNFSF10, TSPAN6), transcription (EHF, PTRF), anti-apoptosis (SERPINB2), keratinocyte differentiation, keratinization and epidermis development (EHF, KRT13, SPRR3, TGM3, CRABP2), and inflammatory response (ANXA1, S100A9). Comparison of aggressive $(\mathrm{N}+$ ) and non-aggressive (N0) larynx tumors also showed interesting differences, including up-regulation of NRG1, a ligand for the receptor tyrosine kinase ErbB3 and $4[30,31]$, and down-regulation of IGFBP3 and keratin $6 \mathrm{~A}($ KRT6A) in $\mathrm{N}+$ tumor. The latter result is interesting since K6-null mice exhibit changes in the oral mucosa resembling those of congenital pachyonychia [32]. In addition, K6a/K6b double-null mice also show localized disintegration of the dorsal tongue epithelium [33]. In relation to IGFBP-3, which has pro-apoptotic properties [34], reduced expression has already been found in tongue SCC cases, and associated with significantly shorter disease-specific and disease-free survival [35]. The authors have suggested that its down-regulation is an early event in head and neck tumorigenesis, with adverse prognostic significance in tongue cancer, and may represent a marker of aggressive disease, reinforcing the results of the present study. 
Table 2: Information on biological processes based on Gene ontology.

\begin{tabular}{|c|c|}
\hline Biological Process & Up-regulated genes \\
\hline \multicolumn{2}{|l|}{ Cell communication } \\
\hline signal transduction & ARHGAP29, BST2, CCL2, CXCLI4, CMIP, FLNB, GNAI2, LY6E \\
\hline cell-cell signaling & BST2, CCL2 \\
\hline Transcription & MZFI, NRGI, RPI3-I22B23.3, ZNF452 \\
\hline Translation & RPS 15, RPS 23 \\
\hline Apoptosis & INCA \\
\hline induction & $B I D$ \\
\hline anti-apoptosis & ANGPTL4, CCL2, IFI6, XAFI \\
\hline Cell adhesion & AJAPI, CCL2, MSLN, SAAI \\
\hline Cell migration & MYH9, SAAI, LUM \\
\hline Cell cycle & PLKI \\
\hline Cell division & MYH9 \\
\hline Cell proliferation & BOLA2, BST2, PLKI \\
\hline \multicolumn{2}{|l|}{ Cellular development process } \\
\hline cell differentiation & MYH9 \\
\hline keratinocyte differentiation & SIOOA7, SPRR2F \\
\hline Cellular structure morphogenesis & MYH9 \\
\hline Developmental process & BST2, SPRR2F \\
\hline organ development & CCL2, MEPE, SPARC \\
\hline epidermis development & COLIAI, COL7AI, KRTI4, LAMC2, SIOOA7, SPRR2F \\
\hline keratinization & SPRR $2 F$ \\
\hline \multicolumn{2}{|l|}{ Response to stimulus } \\
\hline \multicolumn{2}{|l|}{ defense response } \\
\hline inflammatory response & ILIF5, SERPINA3 \\
\hline immune response & BST2, CCL2, IFI6, IFITM2, ILIF5, SEMA3C \\
\hline response to stress & DTL, SGK \\
\hline response to oxidative stress & S100A7 \\
\hline response to external stimulus & CXCLI4, CCL2, GNAI2, SIOOA7, SAAI, SEMA3C, TOPBP \\
\hline Angiogenesis & ANGPTL4, MYH9 \\
\hline Transport & MYH9, NEFL, RBPI, SGK, SLCI5A3, SLC6A8 \\
\hline Metabolic process & NADK \\
\hline protein metabolic process & INCA, LEPRELI, MYH9, NRGI, PRSS2I, PSMCI \\
\hline protein modification process & CCL2, DTL, FKBP9L, HSPEI, ISGI5, SGK, TOR3A \\
\hline lipid metabolic process & APOCI, APOLI, CEL, PLA2G4E, PTGSI, SERPINA3 \\
\hline carbohydrate metabolic process & NANS \\
\hline DNA metabolic process & $D T L, H 3 F 3 B$ \\
\hline nucleic acid metabolic process & OERH \\
\hline RNA processing & LSM4, SNRPD3 \\
\hline Cytoskeleton organization & FLNB, MYH9, NEFL, PLEK2 \\
\hline Extracellular structure organization & LUM \\
\hline
\end{tabular}


Table 2: Information on biological processes based on Gene ontology. (Continued)

\begin{tabular}{ll}
\hline Viral genome replication & CCL2 \\
\hline Cellular homeostasis & CCL2, IFI6, SAAI, SELT \\
\hline No classification & BASPI, CCNYLI, F8AI, FGFBP2, GRAMDIB, IFI27, KIAA I 467, KIAAI 799, KRTDAP, MFAP2, MSMB, NOL6, \\
& OLFML2A, SNCG \\
\hline
\end{tabular}

\section{Down-regulated genes}

\begin{tabular}{|c|c|}
\hline \multicolumn{2}{|l|}{ Cell communication } \\
\hline signal transduction & ANXAI, ARHGAP27, CD24, CRABP2, DBNL, ECMI, GPRI26, IL6R, MAL, TNFSFI0, TSPAN6, TYRO3 \\
\hline cell-cell signaling & CD24, MAL, SIO0A9, TNFSFIO \\
\hline Transcription & CRABP2, EHF, HOP, PTRF \\
\hline \multicolumn{2}{|l|}{ Apoptosis } \\
\hline induction & CLU, MAL, TNFSFIO \\
\hline anti-apoptosis & ANXAI, SERPINB2 \\
\hline Cell adhesion & CLDN4, TYRO3 \\
\hline Cell migration & ANXAI, CD24, PRSS3 \\
\hline Cell proliferation & IL6R, EHF \\
\hline positive regulation & CLU, TSPAN3I, CD24 \\
\hline \multicolumn{2}{|l|}{ Cellular development process } \\
\hline cell differentiation & CLU, HOP, KRTI9, MAL \\
\hline keratinocyte differentiation & A2MLI, ANXAI, SPRR3, TGM3 \\
\hline epithelial cell differentiation & EHF \\
\hline Developmental process & $E H F, I L 6 R, M A L$ \\
\hline organ development & $C L U, H O P, M A L$ \\
\hline ectoderm development & KRT6A \\
\hline epidermis development & CRABP2, KRTI3, SPRR3, TGM3 \\
\hline \multicolumn{2}{|l|}{ epidermal cell differentiation } \\
\hline keratinization & CNFN, PPL, SPRR3 \\
\hline \multicolumn{2}{|l|}{ Response to stimulus } \\
\hline defense response & $\mathrm{NCFI}$ \\
\hline inflammatory response & ANXAI, LYZ, MGLL, SIOOA8, SIOOA9 \\
\hline immune response & $C L U, C R I, G B P 6, I L I R N, I L 6 R$ \\
\hline response to stress & CD24, CLU \\
\hline response to external stimulus & CAT, CD24, CSTB, KRT8, PDE6B, SPRR3 \\
\hline Transport & ALDH3AI, AQP5, ARHGAP27, CAT, CD24, KIFIC, PGD, PLLP, RHCG, SPNS2 \\
\hline Metabolic process & ALDH3AI, CD24, ECHDC3, TPII \\
\hline protein metabolic process & PRSS3, RANBP9, TMPRSSI IE, UBR4, USPIO \\
\hline protein modification process & ANXAI, PRSS3, TGM 3, USPIO \\
\hline lipid metabolic process & AKRIC2, ANXAI, APOD, CLU, LTB4DH, MGLL, PIGF, TPII \\
\hline carbohydrate metabolic process & $P G D, T P I I$ \\
\hline Lymphocyte activation & CD24 \\
\hline Homeostasis & RHCG, CD24 \\
\hline
\end{tabular}


Table 2: Information on biological processes based on Gene ontology. (Continued)

No classification C20orf149, C6orf205, C9orf58, CAPNS2, CRCTI, DIS3L2, FAMI29B, GPRASP2, HPCALI, IER2, IGHAI,
KRT78, LOC342897, LOC643008, LYPD2, LYPD3, MGC59937, MUCI, NUCKSI, PRHI, TMEM59, TPPP3,
ZFANDI

Top up- and down-regulated genes selected from SAGE in tumor samples compared to normal samples.

Table 3: Information on biological processes based on Gene ontology.

\begin{tabular}{|c|c|}
\hline Biological Process & Up-regulated genes \\
\hline \multicolumn{2}{|l|}{ Cell communication } \\
\hline signal transduction & CXCLI4, OR4S2, RPS6KAI, TNFRSFI8, TNFSFIO \\
\hline cell-cell signaling & TOLLIP \\
\hline Transcription & NRGI, SUMOI \\
\hline Apoptosis & INCA \\
\hline induction & TNFSFIO \\
\hline anti-apoptosis & PRKCZ, TNFRSFI8 \\
\hline Cell-adhesion & MSLN \\
\hline Cell cycle & CCNDI, UBE2C \\
\hline \multicolumn{2}{|l|}{ Cell proliferation } \\
\hline negative regulation & EMP3 \\
\hline \multicolumn{2}{|l|}{ Cellular development process } \\
\hline cell differentiation & KRTI9 \\
\hline \multicolumn{2}{|l|}{ Developmental process } \\
\hline $\begin{array}{l}\text { organ development } \\
\text { epidermis development }\end{array}$ & KRTI9 \\
\hline \multicolumn{2}{|l|}{ Response to stimulus } \\
\hline \multicolumn{2}{|l|}{ defense response } \\
\hline inflammatory response & SERPINA3 \\
\hline \multicolumn{2}{|l|}{ response to stress } \\
\hline response to oxidative stress & GPX2 \\
\hline response to external stimulus & CXCLI4, OR4S2 \\
\hline Transport & $H B B$ \\
\hline Metabolic process & NADK \\
\hline protein metabolic process & DKFZP586H2I23, INCA, NRGI, SULF2, UBE2C, USP9X \\
\hline protein modification process & CCNDI, POMT2, PRKCZ, SUMOI, USPI 4 \\
\hline lipid metabolic process & SERPINA3 \\
\hline carbohydrate metabolic process & $D C X R$ \\
\hline RNA metabolic process & PCBP2 \\
\hline RNA processing & RBMI7 \\
\hline DNA repair & SUMOI \\
\hline No classification: & $\begin{array}{l}\text { ANXA7, BRD9, C6orf148, CMIP, FLI23577, LOC283516, LOC28373I, LOC388796, MFAP2, RRPI5, SNCG, } \\
\text { TMEMI09, ZC3H7B }\end{array}$ \\
\hline
\end{tabular}


Table 3: Information on biological processes based on Gene ontology. (Continued)

\begin{tabular}{|c|c|}
\hline & Down-regulated genes \\
\hline Apoptosis & KLK8 \\
\hline induction & IGFBP3 \\
\hline anti-apoptosis & ANGPTL4 \\
\hline Cell adhesion & SAAI \\
\hline Cell migration & SAAI \\
\hline \multicolumn{2}{|l|}{ Cell cycle } \\
\hline Negative regulation & KLKIO \\
\hline \multicolumn{2}{|l|}{ Cell proliferation } \\
\hline Negative regulation & FGFBPI \\
\hline keratynocyte proliferation & KLK8 \\
\hline \multicolumn{2}{|l|}{ Cellular development process } \\
\hline cell differentiation & IGFBP3, KLK8, SPON2 \\
\hline keratinocyte differentiation & SPRR2E, SPRR2F, SPRR 3 \\
\hline $\begin{array}{l}\text { Developmental process } \\
\text { organ development }\end{array}$ & SPRR2E, SPRR2F \\
\hline ectoderm development & KRT6A \\
\hline epidermis development & SPRR2E, SPRR2F, SPRR3 \\
\hline keratinization & SPRR2E, SPRR2F, SPRR3 \\
\hline \multicolumn{2}{|l|}{ Response to stimulus } \\
\hline defense response & NCFI \\
\hline inflammatory response & PI3, SIOOA8, SIOOA9, \\
\hline immune response & DEFB4, HLA-A, PI3, TAPBP \\
\hline response to stress & HIG2, KLK8 \\
\hline response to external stimulus & KLKB, SAAI \\
\hline Angiogenesis & ANGPTL4 \\
\hline Transport & $A L D H 3 A 1, H B A 2, P G D$ \\
\hline Metabolic process & ALDH3AI, TPII \\
\hline protein metabolic process & TAPBP \\
\hline protein modification process & CCT3, FKBP9L, HSPEI, IGFBP3 \\
\hline lipid metabolic process & PLA2G4E, TPII \\
\hline carbohydrate metabolic process & $P G D, T P I I$ \\
\hline Cellular homeostasis & SAAI \\
\hline No classification & $\begin{array}{l}\text { CIOorf99, C9orf58, CAPNS2, FAMI29B, GPRASP2, IGHAI, LMNA, LOC645960, LYPD2, MUCI, NOL6, PSME2, } \\
\text { SLFN13, SNHG8, TJP2, TnCRNA }\end{array}$ \\
\hline
\end{tabular}

Top up- and down-regulated genes selected from SAGE in N+ tumor sample compared to N0 sample.

\section{Potential molecular markers identified by SAGE:}

Validation by Real-Time PCR

The selection of genes for validation by real-time RT-PCR was carried out after an extensive literature analysis of gene expression studies of head and neck carcinomas [3,4,36-66]. The following criteria were used for gene selection: (i) potential involvement in cancer development or aggressiveness and a yet unclear role in HNSCC tumorigenesis, and (ii) similar expression pattern in data reported in the literature as well as in our SAGE experiments.

Using these criteria as guidelines, four genes were selected: two with a pronounced overexpression in SAGE tumor libraries (BST2 and MFAP2), one with an intermediate downregulation profile (KRT31, also referred to as 


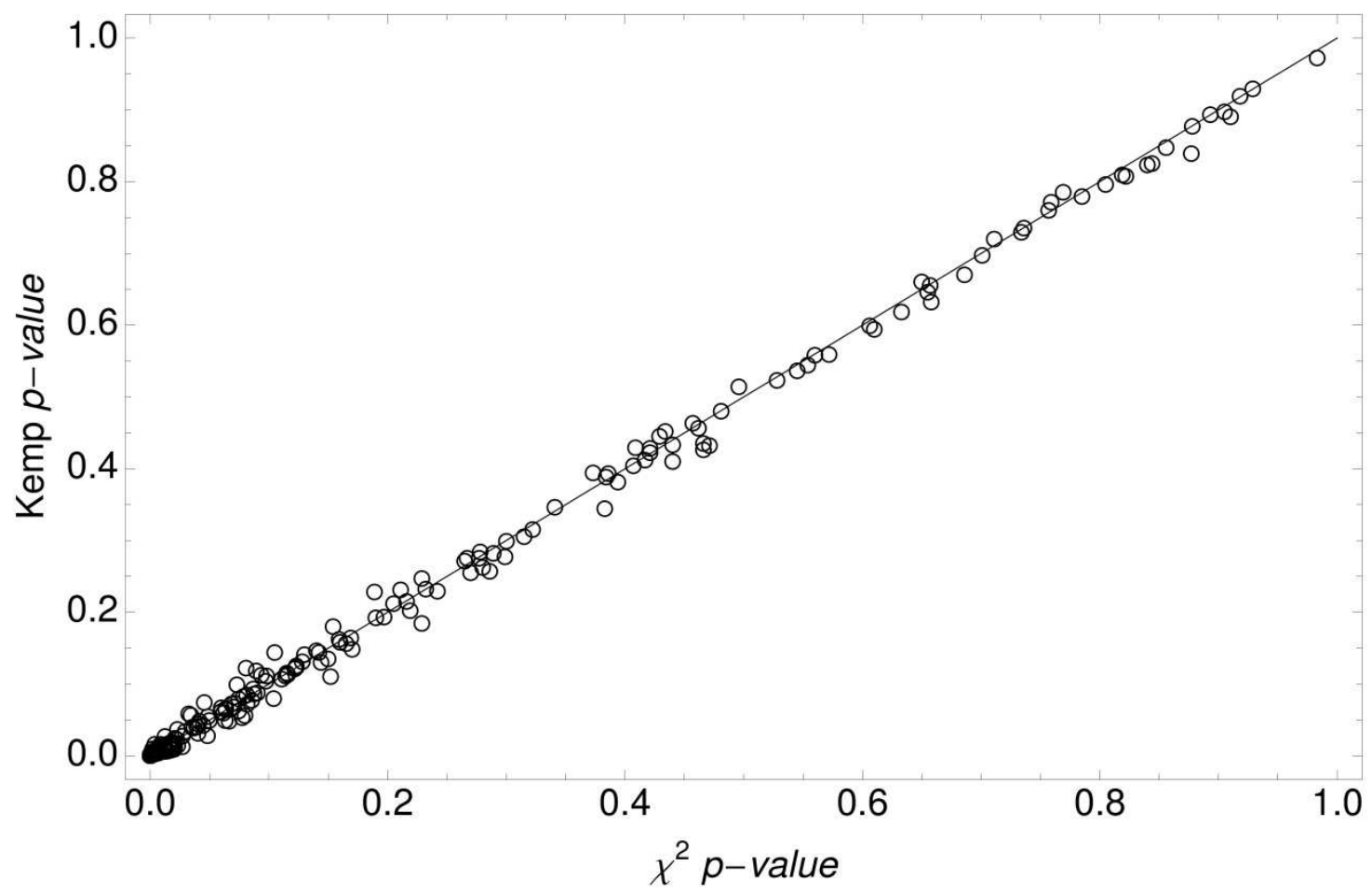

Figure 2

Chi-square p-value versus Kemp value for high-abundance tags.

KRTHA1) and one with a non-significant differential expression pattern (GNA15).

According to the statistical analysis performed, BST2 and MFAP2 tags were expressed at high levels in tumors compared to normal tissues (at least 13-fold or higher), the latter also exhibiting a remarkable overexpression in $\mathrm{N}+$ samples in relation to N0 samples. The normalized frequencies of BST2 tags showed N+ tumor/normal and N0 tumor/normal ratios of 15.8 and 24.3, respectively. For MFAP2, N+ tumor/NO tumor and $\mathrm{N}+$ tumor/normal ratios were 25.3 and 13.5 , respectively. In contrast to these genes, GNA15 showed no differences in gene expression between samples analyzed by SAGE and was selected as a negative control. Although classified as a relevant underexpressed candidate marker in tumors by the statistical analysis of SAGE data, KRT31 displayed less expressive differences between $\mathrm{N}+$ or $\mathrm{N} 0$ tumors and normal tissues. The normalized frequencies of tags are shown in Supplementary Tables 6-11 (Additional file 2). Similar expression patterns of BST2, MFAP2, KRT31 and GNA15 tags were observed by using a chi-square test.
The expression data for the selected genes were validated in 15 pairs of tumor and matched normal tissues from $\mathrm{NO}$ LSCC and 11 pairs from N+ LSCC. The data were also validated in another head and neck subsite by using 36 pairs of tumor and matched normal tissues from tongue squamous cell carcinomas ( $18 \mathrm{~N}+$ and $18 \mathrm{~N}$ ). MFAP2 was upregulated ( $\geq 2$ fold) and KRT31 was downregulated ( $\geq$ 2 -fold) in both $\mathrm{N}+$ and N0 laryngeal tumors versus normal samples, the former also in tongue tumors. BST2 gene was also upregulated but only in NO tumors versus normal tissues. No difference between $\mathrm{N}+$ and $\mathrm{N} 0$ carcinomas was detected for these genes, except for MFAP2 in tongue samples. According to SAGE expression profiles, GNA15 exhibited a non-significant differential expression pattern in carcinomas versus normal tissues, except between $\mathrm{N}+$ and N0 tumors (Figure 4).

The results of the real time PCR experiments were, therefore, in agreement with SAGE data. However, as PCR experiments were performed using a larger number of cases than SAGE, we observed high variability of gene expression among the samples. This finding suggests 


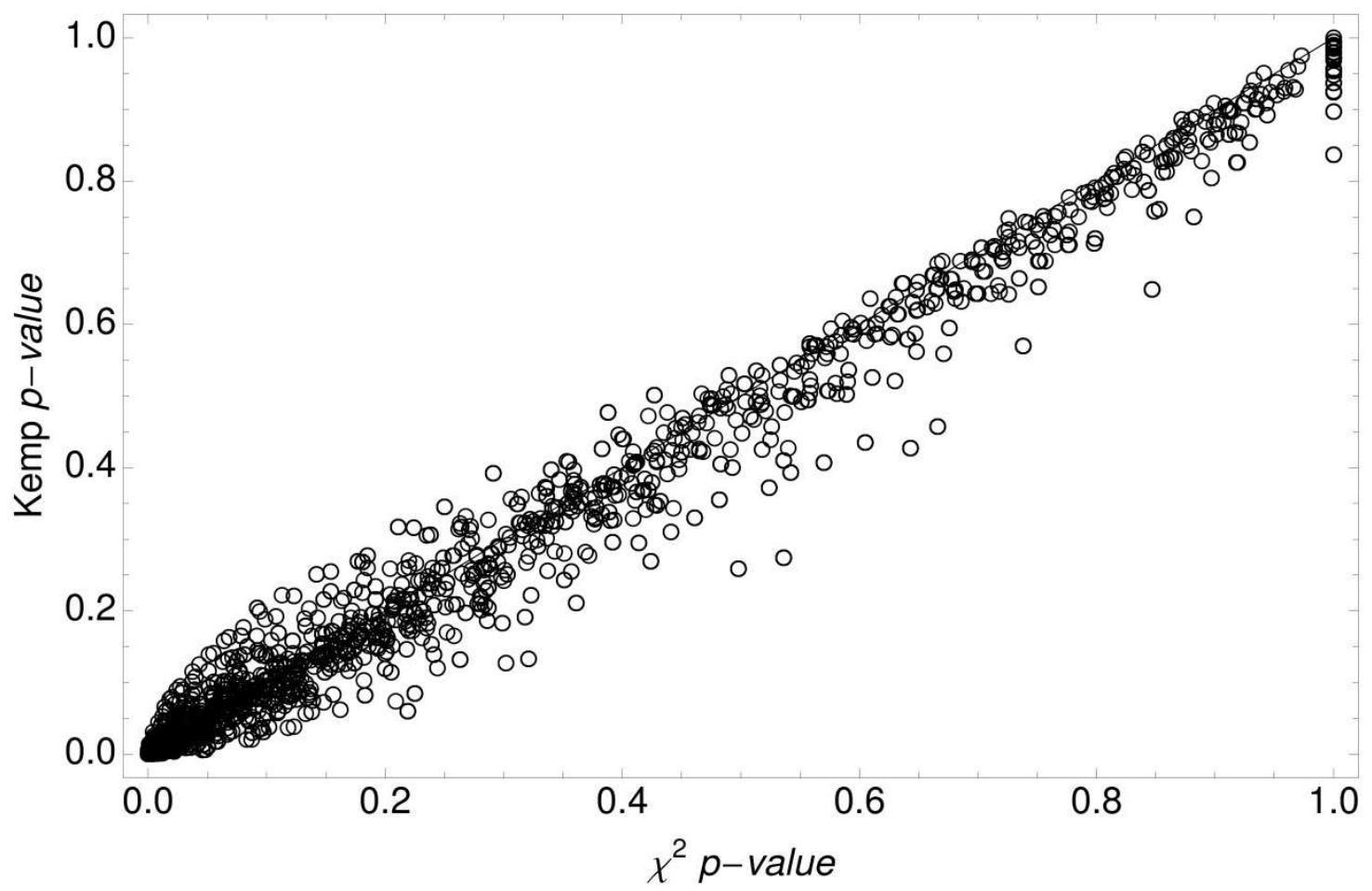

Figure 3

Chi-square p-value versus Kemp value for low-abundance tags.

molecular heterogeneity in HNSCC, as previously stated by Mendez et al. (2002) [55].

The selected genes present intriguing functions related to normal and neoplastic development. KRT31 gene, for example, encodes a type I hair keratin, which is specifically expressed in hair and nails but has been previously observed in normal keratinocytes from buccal mucosa [67]. In cancer, loss of differentiation-specific hair keratins was found in late-stage pilomatrixoma, a skin tumor of follicular origin [68]. Since, keratin 31 has been detected in normal oral mucosa, a similar change in its expression pattern may occur in mucosa-derived squamous carcinomas.

The BST2 gene encodes the bone marrow stromal cell antigen 2, a transmembrane glycoprotein potentially involved in interactions between cancer cells and bone marrow stromal cells and related to angiogenesis, cell proliferation and chromosomal instability [69]. The BST2 promoter region contains putative cis elements for
GATA1, STAT 3 and 1 transcription factors, the latter overexpressed in HNSCCs [70]. BST2 up-regulation has been observed in multiple myeloma, non-Down syndrome (DS) acute megakaryocytic leukemia, tamoxifen-resistant breast cancer [71-73] and, in the present study, was upregulated in HNSCC samples. Stromal cells prevent chemotherapy-induced apoptosis of leukemia cells [74]. The findings of Ge et al. (2006) [73] suggest that BST2 could potentially participate in the leukemia-cell protection from ara-C-induced cytotoxicity mediated by bone marrow stromal cells. These data and the findings of Becker $e t$ al. (2005) [72] on BST2 overexpression in tamoxifenresistant breast cancer indicate that BST2 may possibly represent a new therapeutic target for leukemia as well as for other types of cancer, including HNSCC.

The MFAP2 or MAGP-1 gene encodes the microfibrillarassociated protein 2, a small molecular weight component of extracellular microfibrils, which are structural elements of elastic tissues in the lungs, skin, and vasculature. Miyamoto et al. (2006) [75] showed that MAGP-1 protein 
A

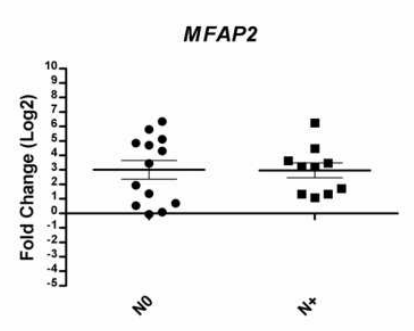

BST2

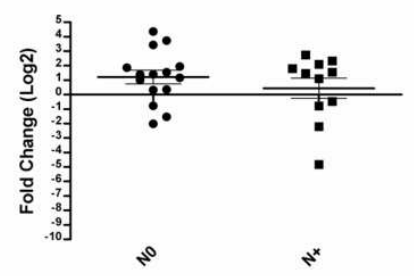

KRT31

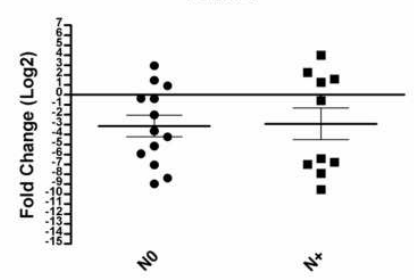

GNA15

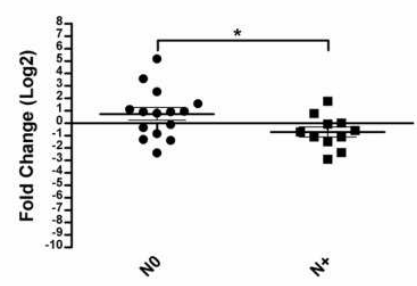

B

\section{Tongue}

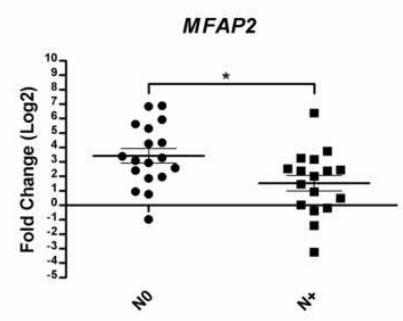

BST2

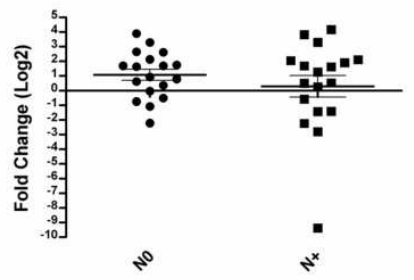

KRT31

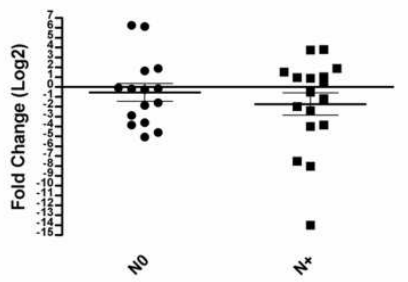

GNA15

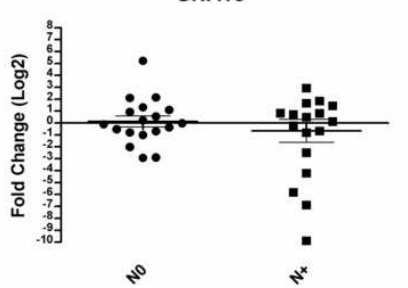

Figure 4

Gene expression in metastatic (N+) and non metatastic (N0) tumors. Expression of BST2, MFAP2, KRT3I and

GNAI 5 was determined by real-time PCR in (A) 26 pairs of larynx tumors and matched normal tissues (I5 N0 and II N+) and (B) 36 pairs of tongue tumor and matched normal samples ( $18 \mathrm{~N}+$ and $18 \mathrm{~N} 0)$. Relative quantitation of target gene expression for each sample was calculated according to Pfaffl [22]; GAPDH was used as the internal reference and normal sample as the calibrator. Values were Log2 transformed (y-axis) so that all values below - I indicate down-regulation in gene expression while values above I represent up-regulation in tumor samples compared to normal samples. Differences in gene expression

between groups ( $\mathrm{N} 0$ and $\mathrm{N}+$ ) were calculated by unpaired $t$ test using GraphPad prism software and were considered statistically significant at $\mathrm{P}<0.05(*)$. The error bar represents the mean \pm S.E.M (standard error of the mean). 
can bind to the Notch1 receptor, leading to a subsequent signaling cascade. In self-renewing tissues and during tumorigenesis, Notch signaling may inhibit differentiation, lineage specification at developmental branch points and induction of differentiation. For example, Notch signaling regulates binary cell fate decisions in the development of the peripheral nervous system in flies. Equipotent precursors give rise to two alternative cell fates: epidermal or neuronal, depending on whether a progenitor cell receives a strong or weak Notch signal. In the skin, Notch induces terminal differentiation of keratinocytes. Therefore, the Notch pathway may lead to different and sometimes opposing outcomes. One explanation is that Notch function is context-dependent [76]. Abnormal Notch activation has been observed in different tumors [77-80] although growth suppression has also been noticed after constitutively over-expressed active Notch1 [81]. Thus, Notch signaling can function as both an oncogene and a tumor suppressor, even within a single tumor, supporting the idea that the Notch 1 pathway is cell-type specific and context-dependent [82].

It is noteworthy that all these three genes (BST2, KRT31, MFAP2) and 27 differentially expressed genes referred to above (ANGPTL4, ANXA1, CCL2, CD24, COL1A1, COL7A1, CRABP2, DBNL, ECM1, EHF, FLNB, GNAI2, IFI6, KRT13, KRT14, LAMC2, MYH9, NRG1, PTRF, S100A7, S100A9, SAA1, SERPINB2, SPRR3, TGM3, TNFSF10, TSPANG) presented the same expression pattern in Oncomine data sets and in our analysis, except two genes which exhibited a different pattern (NRG1, TNFSF10) and five genes with no information in head and neck data sets available through Oncomine (ANGPTL4, FLNB, DBNL, IGFBP3, PTRF).

Overall, the results of the real time PCR experiments showed consistent patterns in HNSCC patients and were in agreement with SAGE analysis. However, little is known about changes at the protein level, and the relationship between gene expression and tumor phenotype as well as the potential value of these genes as biomarkers for HNSCC tumorigenesis should be evaluated in future studies.

\section{Conclusion}

To the best of our knowledge, this is the first study reporting SAGE data in head and neck squamous cell tumors. The analysis of SAGE data by our statistical approach was effective in identifying differentially expressed genes reportedly involved in cancer development. In agreement with our statistical analysis, three genes (BST2, MFAP2 and KRT31) selected for validation experiments were differentially expressed in an independent subset of HNSCCs compared to normal tissues or in metastatic versus nonmetastatic samples. The selected genes have not been pre- viously implicated in head and neck tumorigenesis. In addition, our data suggest a role for Notch signaling in HNSCC tumorigenesis, together with factors involved in keratinocyte differentiation, keratinization and epidermis development. The confirmation of the differential expression of this subset of genes selected from LSCC SAGE libraries in other HNSCC sites reinforce the existence of potential common biomarkers for prognosis and targeted therapy of such tumors.

\section{Competing interests}

The authors declare that they have no competing interests.

\section{Authors' contributions}

NJFS participated in the design of the study and analysis of the data, developed the expression database and bioinformatic tools and drafted the manuscript. LV participated in the analysis of the data, developed the expression database and statistical tools. AM-L, ML, PS carried out the analysis and interpretation of the data and drafted the manuscript, DGP carried out the SAGE database. RVR performed the real time PCR experiments and data analysis. FGN and GENCAPO team members were responsible for sample and data collection and initial on-site sample processing, sequencing SAGE libraries, provided the pathological analysis of the cases, obtained informed consent and discussed the findings. WASJ carried out the SAGE experiments and analysis and helped in the interpretation of data. CABP participated in the study design and coordination, carried out the analysis and interpretation of the data and drafted the manuscript. EHT participated in the study design and coordination, was responsible for sequencing SAGE libraries, carried out the analysis and interpretation of the data and drafted the manuscript. All authors read and approved the final manuscript.

\section{Appendix}

The GENCAPO (Head and Neck Genome) Project authors are the following: Cury $\mathrm{PM}^{7}$, de Carvalho $\mathrm{MB}^{8}$, Dias-Neto $\mathrm{E}^{3}$, Figueiredo DLA9, Fukuyama $\mathrm{EE}^{5}$, Góis-Filho $\mathrm{JF}^{5}$, Leopoldino $\mathrm{AM}^{15}$, Mamede $\mathrm{RCM}^{9}$, Michaluart-Junior $\mathrm{P}^{6}$, Moreira-Filho $\mathrm{CA}^{1}$, Moyses $\mathrm{RA}^{6}$, Nóbrega $\mathrm{FG}^{4}$, Nóbrega $\mathrm{MP}^{4}$, Nunes $\mathrm{FD}^{13}$, Ojopi EPB 3 , Okamoto $\mathrm{OK}^{14}$, Serafini $\mathrm{LN}^{10}$, Severino $\mathrm{P}^{1}$, Silva $\mathrm{AMA}^{8}$, Silva Jr WA ${ }^{11}$, Silveira $\mathrm{NJF}^{16}$, Souza SCOM${ }^{13}$, Tajara $\mathrm{EH}^{2}$, Wünsch-Filho $\mathrm{V}^{12}$, Zago MA ${ }^{17}$, Amar A ${ }^{8}$, Arap SS6, Araújo NSS6, Araújo-Filho $\mathrm{V}^{6}$, Barbieri RB 8 , Bandeira $\mathrm{CM}^{4}$, Bastos $\mathrm{AU}^{8}$, Braconi $\mathrm{MA}^{4}$, Brandão $\mathrm{LG}^{6}$, Brandão RM ${ }^{11}$, Canto $\mathrm{AL}^{4}$, Carmona-Raphe $\mathrm{J}^{2}$, Carvalho-Neto $\mathrm{PB}^{8}$, Casemiro $\mathrm{AF}^{8}$, Cerione $\mathrm{M}^{5}$, Cernea $\mathrm{CR}^{6}$, Cicco R5, Chagas $\mathrm{MJ}^{4}$, Chedid $\mathrm{H}^{8}$, Chiappini $\mathrm{PBO}^{8}$, Correia $\mathrm{LA}^{8}$, Costa $\mathrm{A}^{12}$, Costa $\mathrm{ACW}^{8}$, Cunha $\mathrm{BR}^{2}$, Curioni $\mathrm{OA}^{8}$, Dias $\mathrm{THG}^{3}$, Durazzo $\mathrm{M}^{6}$, Ferraz $\mathrm{AR}^{6}$, Figueiredo $\mathrm{RO}^{12}$, Fortes $\mathrm{CS}^{12}$, Franzi $\mathrm{SA}^{8}$, Frizzera $\mathrm{APZ}^{7}$, Gallo $\mathrm{J}^{6}$, Gazito $\mathrm{D}^{8}$, Guimarães $\mathrm{PEM}^{6}$, Gutierres $\mathrm{AP}^{8}$, Inamine $\mathrm{R}^{12}$, Kaneto $\mathrm{CM}^{11}$, Lehn $\mathrm{CN}^{8}$, López $\mathrm{RVM}^{12}$, Macarenco $\mathrm{R}^{4}$, 
Magalhães $\mathrm{RP}^{6}$, Martins $\mathrm{AE}^{8}$, Meneses $\mathrm{C}^{4}$, Mercante $\mathrm{AMC}^{8}$, Montenegro FLM ${ }^{6}$, Pinheiro DG ${ }^{11}$, Polachini GM ${ }^{2}$, Porsani $\mathrm{AF}^{8}$, Rapoport $\mathrm{A}^{8}$, Rodini $\mathrm{CO}^{13}$, Rodrigues $\mathrm{AN}^{12}$, Rodrigues-Lisoni $\mathrm{FC}^{2}$, Rodrigues $\mathrm{RV}^{2}$, Rossi $\mathrm{L}^{8}$, Santos $\mathrm{ARD}^{11}$, Santos $\mathrm{M}^{8}$, Settani $\mathrm{F}^{5}$, Silva FAM ${ }^{15}$, Silva $\mathrm{IT}^{11}$, Silva-Filho $\mathrm{GB}^{6}$, Smith $\mathrm{RB}^{6}$, Souza $\mathrm{TB}^{8}$, Stabenow E6, Takamori JT ${ }^{8}$, Tavares $\mathrm{MR}^{6}$, Turcano $\mathrm{R}^{6}$, Valentim $\mathrm{PJ}^{5}$, Vidotto $\mathrm{A}^{2}$, Volpi $\mathrm{EM}^{6}$, Xavier FCA ${ }^{13}$, Yamagushi F5, Cominato $\mathrm{ML}^{5}$, Correa $\mathrm{PMS}^{4}$, Mendes $\mathrm{GS}^{5}$, Paiva R ${ }^{5}$, Ramos $\mathrm{O}^{6}$, Silva $\mathrm{C}^{6}$, Silva $\mathrm{MJ}^{5}$, Tarlá MVC ${ }^{11}$.

Affiliations: ${ }^{1}$ Instituto de Ensino e Pesquisa Albert Einstein, São Paulo; ${ }^{2}$ Departamento de Biologia Molecular, Faculdade de Medicina de São José do Rio Preto; ${ }^{3}$ Departamento e Instituto de Psiquiatria, Faculdade de Medicina, Universidade de São Paulo (USP), São Paulo; ${ }^{4}$ Departamento de Biociências e Diagnóstico Bucal, Faculdade de Odontologia, Universidade Estadual Paulista, São José dos Campos, São Paulo, ${ }^{5}$ Serviço de Cirurgia de Cabeça e Pescoço, Instituto do Câncer Arnaldo Vieira de Carvalho, São Paulo; ${ }^{6}$ Departamento de Cirurgia de Cabeça e Pescoço, Faculdade de Medicina, USP, São Paulo; ${ }^{7}$ Departamento de Patologia, Faculdade de Medicina de São José do Rio Preto; ${ }^{8}$ Hospital Heliópolis, São Paulo; 'Serviço de Cirurgia de Cabeça e Pescoço, Faculdade de Medicina de Ribeirão Preto, USP; ${ }^{10}$ Departamento de Patologia, Faculdade de Medicina de Ribeirão Preto, USP; ${ }^{11}$ Departamento de Genética, Faculdade de Medicina de Ribeirão Preto, USP; 12Departamento de Epidemiologia, Faculdade de Saúde Pública, USP, São Paulo; ${ }^{13}$ Departamento de Estomatologia, Faculdade de Odontologia da USP, São Paulo; ${ }^{14}$ Departamento de Neurologia/Neurocirurgia, UNIFESP, São Paulo; ${ }^{15}$ Departamento de Análises Clínicas, Toxicológicas e Bromatológicas, Faculdade de Ciências Farmacêuticas de Ribeirão Preto, USP; ${ }^{16}$ Instituto de Pesquisa e Desenvolvimento, UNIVAP, São José dos Campos; ${ }^{17}$ Departamento de Clínica Médica, Faculdade de Medicina de Ribeirão Preto, USP, SP, Brazil.

\section{Additional material}

\section{Additional file 1}

Supplementary Table 1. Tags with different frequencies between larynx SAGE libraries according to the criteria described in the Materials and Methods section. Supplementary Table 2. A total of 8,979 tags expressed in the N+ tumor SAGE library. Supplementary Table 3. A total of 17,588 tags expressed in the NO tumor SAGE library. Supplementary Table 4. A total of 15,102 tags expressed in the control SAGE library. Supplementary Table 5. A total of 12,229 tags expressed in at least two SAGE libraries. Click here for file

[http://www.biomedcentral.com/content/supplementary/17558794-1-56-S1.xls]

\section{Additional file 2}

Supplementary Table 6. Sixty top-up regulated tags in aggressive versus non-aggressive larynx library. Supplementary Table 7. Sixty top-down regulated tags in aggressive versus non-aggressive larynx library. Supplementary Table 8. Sixty top-up regulated tags in aggressive versus normal larynx library. Supplementary Table 9. Sixty top-down regulated tags in aggressive versus normal larynx library. Supplementary Table 10. Sixty top-up regulated tags in non-aggressive versus normal larynx library. Supplementary Table 11. Sixty top-down regulated tags in non-aggressive versus normal larynx library.

Click here for file

[http://www.biomedcentral.com/content/supplementary/17558794-1-56-S2.xls]

\section{Additional file 3}

Supplementary Table 12. Discrepancies between Kemp and chi-square analysis of SAGE data set.

Click here for file

[http://www.biomedcentral.com/content/supplementary/17558794-1-56-S3.xls]

\section{Acknowledgements}

We thank Anne Murray (Ludwig Institute for Cancer Research, NY Branch) for critically reading the English manuscript. We also acknowledge the financial support from Fundação de Amparo à Pesquisa do Estado de São Paulo/FAPESP (Grants 05/5 |467-0, 04/I2054-9 and 07/50894-7) and from The Ludwig Institute for Cancer Research, and the researcher fellowships from FAPESP (AM-L), Conselho Nacional de Pesquisas/CNPq (CABP, EHT) and Coordenação de Aperfeiçoamento do Pessoal do Ensino Superior/ CAPES.

\section{References}

I. Parkin DM, Bray F, Ferlay J, Pisani P: Global cancer statistics, 2002. CA Cancer J Clin 2005, 55:74-108.

2. Brasil: Estimativa 2008: Incidência de Câncer no Brasil. In Rio de Janeiro: Ministério da Saúde. Secretaria de Atenção à Saúde Instituto Nacional do Câncer; 2007.

3. Marcus B, Arenberg D, Lee J, Kleer C, Chepeha DB, Schmalbach CE, Islam M, Paul S, Pan Q, Hanash S, et al.: Prognostic factors in oral cavity and oropharyngeal squamous cell carcinoma. Cancer cavity and orophary
2004, 101:2779-2787.

4. Chin D, Boyle GM, Williams RM, Ferguson K, Pandeya N, Pedley J, Campbell CM, Theile DR, Parsons PG, Coman WB: Novel markers for poor prognosis in head and neck cancer. Int J Cancer 2005, I I 3:789-797.

5. Greenlee RT, Hill-Harmon MB, Murray T, Thun M: Cancer statistics, 2001. CA Cancer J Clin 200I, 5I:15-36.

6. Jemal A, Siegel R, Ward E, Murray T, Xu J, Smigal C, Thun MJ: Cancer statistics, 2006. CA Cancer / Clin 2006, 56: 106-130.

7. Gollin SM: Chromosomal alterations in squamous cell carcinomas of the head and neck: window to the biology of disease. Head Neck 200I, 23:238-253.

8. Sidransky D: Emerging molecular markers of cancer. Nat Rev Cancer 2002, 2:210-219.

9. Hunter KD, Parkinson EK, Harrison PR: Profiling early head and neck cancer. Nat Rev Cancer 2005, 5:127-135.

10. Velculescu VE, Zhang L, Vogelstein B, Kinzler KW: Serial analysis of gene expression. Science 1995, 270:484-487.

II. van Baal JW, Milana F, Rygiel AM, Sondermeijer CM, Spek CA, Bergman JJ, Peppelenbosch MP, Krishnadath KK: A comparative analy$s$ s by SAGE of gene expression profiles of esophageal adenocarcinoma and esophageal squamous cell carcinoma. Cell Oncol 2008, 30:63-75.

12. DeRisi J, Penland L, Brown PO, Bittner ML, Meltzer PS, Ray M, Chen $\mathrm{Y}$, Su YA, Trent JM: Use of a cDNA microarray to analyse gene 
expression patterns in human cancer. Nat Genet 1996, 1 4:457-460.

13. DuBois P: MySQL. Indianapolis: New Riders Publishing; 2000.

14. Wall L, Christiansen T, Orwant J: Programming Perl. 3rd edition. Sebastopol: O'Reilly Associates Inc; 2000.

15. Cox DR: Partial Likelihood. Biometrika 1975, 62:269-276.

16. Dempster AP: The direct use of likelihood for significance testing. Statist Comput 1997, 7:247-252.

17. DeGroot MH: Probability and Statistics. New York: Addison Wesley; 1975

18. Varuzza L, Pereira CAB: Comparative Enumeration Gene Expression. Nature Precedings; . 23 June 2008.

19. GeneOntology [http://www.geneontology.org/]

20. Oncomine [http://www.oncomine.org/]

21. Vandesompele J, De Preter K, Pattyn F, Poppe B, Van Roy N, De Paepe A, Speleman F: Accurate normalization of real-time quantitative RT-PCR data by geometric averaging of multiquantitative RT-PCR data by geom

22. Pfaff MW: A new mathematical model for relative quantification in real-time RT-PCR. Nucleic Acids Res 2001, 29:e45.

23. SAGEGenie [http://cgap.nci.nih.gov/SAGE]

24. SAGEmap [http://www.ncbi.nlm.nih.gov/SAGE/]

25. Man MZ, Wang X, Wang Y: POWER_SAGE: comparing statistical tests for SAGE experiments. Bioinformatics 2000 I6(II):953-959.

26. Romualdi C, Bortoluzzi S, Danieli GA: Detecting differentially expressed genes in multiple tag sampling experiments: comparative evaluation of statistical tests. Hum Mol Genet 2001 . 10(19):2133-2141.

27. Ruijter JM, Van Kampen AH, Baas F: Statistical evaluation of SAGE libraries: consequences for experimental design. Physiol Genomics 2002, II(2):37-44.

28. Romualdi C, Bortoluzzi S, D'Alessi F, Danieli GA: IDEG6: a web tool for detection of differentially expressed genes in multiple tag sampling experiments. Physiol Genomics 2003, 12(2): 159-162.

29. Holloway DT, Kon M, Delisi C: Classifying transcription factor targets and discovering relevant biological features. Biol Direct 2008, 3:22

30. Sliwkowski MX, Schaefer G, Akita RW, Lofgren JA, Fitzpatrick VD, Nuijens A, Fendly BM, Cerione RA, Vandlen RL, Carraway KL 3rd: Coexpression of erbB2 and erbB 3 proteins reconstitutes a Coexpression of erbB2 and erbB3 proteins reconstitutes a
high affinity receptor for heregulin. I Biol Chem 1994, 269: $14661-14665$.

31. Plowman GD, Green JM, Culouscou JM, Carlton GW, Rothwell VM, Buckley S: Heregulin induces tyrosine phosphorylation of HER4/p 1 80erbB4. Nature 1993, 366:473-475.

32. Wong P, Colucci-Guyon E, Takahashi K, Gu C, Babinet C, Coulombe PA: Introducing a null mutation in the mouse K6alpha and K6beta genes reveals their essential structural role in the oral mucosa. J Cell Biol 2000, 150:921-928.

33. Wojcik SM, Longley MA, Roop DR: Discovery of a novel murine keratin 6 (K6) isoform explains the absence of hair and nail defects in mice deficient for K6a and K6b. J Cell Biol 200I, 154:619-630.

34. Rajah R, Lee KW, Cohen P: Insulin-like growth factor binding protein-3 mediates tumor necrosis factor-alpha-induced apoptosis: role of $\mathrm{Bcl}-2$ phosphorylation. Cell Growth Differ 2002, 13:163-171.

35. Papadimitrakopoulou VA, Brown EN, Liu DD, El-Naggar AK, Jack Lee J, Hong WK, Lee HY: The prognostic role of loss of insulin-like growth factor-binding protein-3 expression in head and neck carcinogenesis. Cancer Lett 2006, 239:136-143.

36. Alevizos I, Mahadevappa M, Zhang X, Ohyama H, Kohno Y, Posner M, Gallagher GT, Varvares M, Cohen D, Kim D, et al:: Oral cancer in vivo gene expression profiling assisted by laser capture microdissection and microarray analysis. Oncogene 2001, 20:6196-6204.

37. Al Moustafa AE, Alaoui-Jamali MA, Batist G, Hernandez-Perez M, Serruya C, Alpert L, Black MJ, Sladek R, Foulkes WD: Identification of genes associated with head and neck carcinogenesis by cDNA microarray comparison between matched primary normal epithelial and squamous carcinoma cells. Oncogene 2002, $21: 2634-2640$
38. Banerjee AG, Bhattacharyya I, Vishwanatha JK: Identification of genes and molecular pathways involved in the progression of premalignant oral epithelia. Mol Cancer Ther 2005, 4:865-875.

39. Belbin TJ, Singh B, Barber I, Socci N, Wenig B, Smith R, Prystowsky $\mathrm{MB}$, Childs G: Molecular classification of head and neck squamous cell carcinoma using cDNA microarrays. Cancer Res mous cell carcinoma

40. Belbin TJ, Singh B, Smith RV, Socci ND, Wreesmann VB, Sanchez-Carbayo M, Masterson J, Patel S, Cordon-Cardo C, Prystowsky MB, et al: Molecular profiling of tumor progression in head and neck cancer. Arch Otolaryngol Head Neck Surg 2005, 131:10-18.

41. Carinci F, Lo Muzio L, Piattelli A, Rubini C, Palmieri A, Stabellini G, Maiorano E, Pastore A, Laino G, Scapoli L, et al.: Genetic portrait of mild and severe lingual dysplasia. Oral Oncol 2005, 41:365-374.

42. Cromer A, Carles A, Millon R, Ganguli G, Chalmel F, Lemaire F, Young J, Dembele D, Thibault C, Muller D, et al.: Identification of genes associated with tumorigenesis and metastatic potential of hypopharyngeal cancer by microarray analysis. Oncotial of hypopharyngeal

43. Dasgupta S, Tripathi PK, Qin H, Bhattacharya-Chatterjee M, Valentino J, Chatterjee SK: Identification of molecular targets for immunotherapy of patients with head and neck squamous cell carcinoma. Oral Oncol 2006, 42:306-316.

44. El-Naggar AK, Kim HW, Clayman GL, Coombes MM, Le B, Lai S, Zhan F, Luna MA, Hong WK, Lee J]: Differential expression profiling of head and neck squamous carcinoma: significance in their phenotypic and biological classification. Oncogene 2002, 21:8206-8219.

45. Ginos MA, Page GP, Michalowicz BS, Patel KJ, Volker SE, Pambuccian $\mathrm{SE}$, Ondrey FG, Adams GL, Gaffney PM: Identification of a gene expression signature associated with recurrent disease in expression signature associated with recurrent disease in
squamous cell carcinoma of the head and neck. Cancer Res 2004, 64:55-63

46. Gonzalez HE, Gujrati M, Frederick M, Henderson Y, Arumugam J, Spring PW, Mitsudo K, Kim HW, Clayman GL: Identification of 9 genes differentially expressed in head and neck squamous cell carcinoma. Arch Otolaryngol Head Neck Surg 2003, I 29:754-759.

47. Ha PK, Benoit NE, Yochem R, Sciubba J, Zahurak M, Sidransky D, Pevsner J, Westra WH, Califano J: A transcriptional progression model for head and neck cancer. Clin Cancer Res 2003, 9:3058-3064.

48. Hwang D, Alevizos I, Schmitt WA, Misra J, Ohyama H, Todd R, Mahadevappa M, Warrington JA, Stephanopoulos G, Wong DT, et al.: Genomic dissection for characterization of cancerous oral epithelium tissues using transcription profiling. Oral Oncol 2003, 39:259-268.

49. Irie $T$, Aida $T$, Tachikawa $T$ : Gene expression profiling of oral squamous cell carcinoma using laser microdissection and cDNA microarray. Med Electron Microsc 2004, 37:89-96.

50. Jeon GA, Lee JS, Patel V, Gutkind JS, Thorgeirsson SS, Kim EC, Chu IS, Amornphimoltham P, Park MH: Global gene expression profiles of human head and neck squamous carcinoma cell lines. Int J Cancer 2004, I I 2:249-258.

51. Kuriakose MA, Chen WT, He ZM, Sikora AG, Zhang P, Zhang ZY, Qiu WL, Hsu DF, McMunn-Coffran C, Brown SM, et al.: Selection and validation of differentially expressed genes in head and neck cancer. Cell Mol Life Sci 2004, 61: 1372-1383.

52. Leethanakul C, Knezevic V, Patel V, Amornphimoltham P, Gillespie J, Shillitoe EJ, Emko P, Park MH, Emmert-Buck MR, Strausberg RL, et al: Gene discovery in oral squamous cell carcinoma through the Head and Neck Cancer Genome Anatomy Project: confirmation by microarray analysis. Oral Oncol 2003, 39:248-258.

53. Leethanakul C, Patel V, Gillespie J, Pallente M, Ensley JF, Koontongkaew S, Liotta LA, Emmert-Buck M, Gutkind JS: Distinct pattern of expression of differentiation and growth-related genes in squamous cell carcinomas of the head and neck revealed by the use of laser capture microdissection and cDNA arrays. Oncogene 2000, 19:3220-3224.

54. Li Y, St John MA, Zhou X, Kim Y, Sinha U, Jordan RC, Eisele D, Abemayor E, Elashoff D, Park NH, et al.: Salivary transcriptome diagnostics for oral cancer detection. Clin Cancer Res 2004, 10:8442-8450.

55. Mendez E, Cheng C, Farwell DG, Ricks S, Agoff SN, Futran ND, Weymuller EA Jr, Maronian NC, Zhao LP, Chen C: Transcriptional 
expression profiles of oral squamous cell carcinomas. Cancer 2002, 95: $1482-1494$

56. Moriya T, Seki N, Shimada K, Kato M, Yakushiji T, Nimura Y, Uzawa $\mathrm{K}$, Takiguchi M, Tanzawa H: In-house cDNA microarray analysis of gene expression profiles involved in SCC cell lines. Int J Mol Med 2003, I 2:429-435

57. Nagata M, Fujita $H$, Ida H, Hoshina H, Inoue T, Seki Y, Ohnishi M, Ohyama T, Shingaki S, Kaji M, et al.: Identification of potential biomarkers of lymph node metastasis in oral squamous cell carcinoma by cDNA microarray analysis. Int $\mathrm{J}$ Cancer 2003 , 106:683-689.

58. Schlingemann J, Habtemichael N, Ittrich C, Toedt G, Kramer H, Hambek M, Knecht R, Lichter P, Stauber R, Hahn M: Patient-based cross-platform comparison of oligonucleotide microarray expression profiles. Lab Invest 2005, 85:1024-1039.

59. Schmalbach CE, Chepeha DB, Giordano TJ, Rubin MA, Teknos TN, Bradford CR, Wolf GT, Kuick R, Misek DE, Trask DK, et al:: Molecular profiling and the identification of genes associated with ular profiling and the identification of genes associated with
metastatic oral cavity/pharynx squamous cell carcinoma. metastatic oral cavity/pharynx squamous cell
Arch Otolaryngol Head Neck Surg 2004, I 30:295-302

60. Sok JC, Kuriakose MA, Mahajan VB, Pearlman AN, DeLacure MD, Chen FA: Tissue-specific gene expression of head and neck squamous cell carcinoma in vivo by complementary DNA microarray analysis. Arch Otolaryngol Head Neck Surg 2003, 129:760-770.

61. Squire JA, Bayani J, Luk C, Unwin L, Tokunaga J, MacMillan C, Irish J, Brown D, Gullane P, Kamel-Reid S: Molecular cytogenetic analysis of head and neck squamous cell carcinoma: By comparative genomic hybridization, spectral karyotyping, and tive genomic hybridization, spectral karyotyping,

62. Tsai WC, Tsai ST, Ko IY, Jin YT, Li C. Huang W Young KC, Lai MD Liu HS, Wu LW: The mRNA profile of genes in betel quid chewing oral cancer patients. Oral Oncol 2004, 40:418-426.

63. Villaret DB, Wang T, Dillon D, Xu J, Sivam D, Cheever MA, Reed SG: Identification of genes overexpressed in head and neck squamous cell carcinoma using a combination of complementary DNA subtraction and microarray analysis. Laryngoscope 2000 I 10:374-38I.

64. Roepman P, Wessels LF, Kettelarij N, Kemmeren P, Miles AJ, Lijnzaad P, Tilanus MG, Koole R, Hordijk G], Vliet PC van der, et al.: An expression profile for diagnosis of lymph node metastases from primary head and neck squamous cell carcinomas. Nat from primary head and

65. O'Donnell RK, Kupferman M, Wei SJ, Singhal S, Weber R, O'Malley B, Cheng Y, Putt M, Feldman M, Ziober B, et al:: Gene expression signature predicts lymphatic metastasis in squamous cell carcinoma of the oral cavity. Oncogene 2005, 24:|244-|25|.

66. Rhodes DR, Yu J, Shanker K, Deshpande N, Varambally R, Ghosh D Barrette T, Pandey A, Chinnaiyan AM: Large-scale meta-analysis of cancer microarray data identifies common transcriptional profiles of neoplastic transformation and progression. Proc Natl Acad Sci USA 2004, 101:9309-9314.

67. Hansson A, Bloor BK, Sarang Z, Haig Y, Morgan PR, Stark HJ, Fusenig NE, Ekstrand J, Grafstrom RC: Analysis of proliferation, apoptosis and keratin expression in cultured normal and immortalsis and keratin expression in cultured normal and immortal-

68. Cribier B, Peltre B, Langbein L, Winter H, Schweizer J, Grosshans E: Expression of type I hair keratins in follicular tumours. $\mathrm{Br}$ J Dermatol 200I, 144:977-982.

69. Wong YF, Cheung TH, Lo KW, Yim SF, Siu NS, Chan SC, Ho TW, Wong KW, Yu MY, Wang WW, et al:: Identification of molecular markers and signaling pathway in endometrial cancer in Hong Kong Chinese women by genome-wide gene expression profiling. Oncogene 2007, 26:1971-1982.

70. Nikitakis NG, Siavash H, Sauk Jj: Targeting the STAT pathway in head and neck cancer: recent advances and future prospects. Curr Cancer Drug Targets 2004, 4:637-65I.

71. Ohtomo T, Sugamata $Y$, Ozaki $Y$, Ono K, Yoshimura $Y$, Kawai S, Koishihara Y, Ozaki S, Kosaka M, Hirano T, et al:: Molecular cloning and characterization of a surface antigen preferentially overexpressed on multiple myeloma cells. Biochem Biophys Res Commun 1999, 258:583-591.

72. Becker M, Sommer A, Kratzschmar JR, Seidel H, Pohlenz HD, Fichtner I: Distinct gene expression patterns in a tamoxifen-sensitive human mammary carcinoma xenograft and its tamoxifen-resistant subline MaCa 3366/TAM. Mol Cancer Ther 2005, 4:|5|-168.

73. Ge Y, Dombkowski AA, LaFiura KM, Tatman D, Yedidi RS, Stout ML, Buck SA, Massey G, Becton DL, Weinstein HJ, et al: Differential gene expression, GATAI target genes, and the chemotherapy sensitivity of Down syndrome megakaryocytic leukemia. apy sensitivity of Down synd

74. Konopleva M, Konoplev S, Hu W, Zaritskey AY, Afanasiev BV, Andreeff M: Stromal cells prevent apoptosis of AML cells by up-regulation of anti-apoptotic proteins. Leukemia 2002, 16:1713-1724

75. Miyamoto A, Lau R, Hein PW, Shipley JM, Weinmaster G: Microfibrillar proteins MAGP-I and MAGP-2 induce NotchI extracellular domain dissociation and receptor activation. I Biol Chem 2006, 28I: 10089-10097.

76. Wilson A, Radtke F: Multiple functions of Notch signaling in self-renewing organs and cancer. FEBS Lett 2006, 580:2860-2868.

77. Nickoloff BJOB, Miele L: Notch signaling as a therapeutic target in cancer: a new approach to the development of cell fate modifying agents. Oncogene 2003, 22:6598-6608.

78. Fan X, Mikolaenko I, Elhassan I, Ni X, Wang Y, Ball D, Brat DJ, Perry $A$, Eberhart CG: Notch I and notch2 have opposite effects on embryonal brain tumor growth. Cancer Res 2004, 64:7787-7793.

79. Houde C, Li Y, Song L, Barton K, Zhang Q, Godwin J, Nand S, Toor A, Alkan S, Smadja NV, et al.: Overexpression of the NOTCH ligand JAG2 in malignant plasma cells from multiple myeloma patients and cell lines. Blood 2004, 104:3697-3704.

80. Liu ZJ, Xiao M, Balint K, Smalley KS, Brafford P, Oiu R, Pinnix CC, Li $X$, Herlyn M: NotchI signaling promotes primary melanoma progression by activating mitogen-activated protein kinasel progression by activating mitogen-activated protein kinase/
phosphatidylinositol 3-kinase-Akt pathways and up-regulatphosphatidylinositol 3-kinase-Akt pathways and up-regulat.

81. Duan L, Yao J, Wu X, Fan M: Growth suppression induced by Notchl activation involves Wnt-beta-catenin down-regulation in human tongue carcinoma cells. Biol Cell 2006, 98:479-490.

82. Leong KG, Karsan A: Recent insights into the role of Notch signaling in tumorigenesis. Blood 2006, 107:2223-2233.

\section{Pre-publication history}

The pre-publication history for this paper can be accessed here:

http://www.biomedcentral.com/1755-8794/1/56/prepub

Publish with BioMed Central and every scientist can read your work free of charge

"BioMed Central will be the most significant development for disseminating the results of biomedical research in our lifetime."

Sir Paul Nurse, Cancer Research UK

Your research papers will be:

- available free of charge to the entire biomedical community

- peer reviewed and published immediately upon acceptance

- cited in PubMed and archived on PubMed Central

- yours - you keep the copyright 


\section{CAPÍtulo 5}

\section{INTRODUÇÃ̃O}

As proteínas RIP (receptor-interacting proteins) compreendem uma família de cinases de serina/treonina que integram sinais de estresse extra e intracelulares causados por diferentes fatores, incluindo infecções, inflamação e lesões no DNA. Respostas prósobrevivência, inflamatórias e imune, bem como padrões de sinalização indutores de morte celular dependem das cinases RIP.

A proteína RIP2 (também conhecida como RICK ou CARDIAK), assim como outras RIPs, ativa o NF- $\kappa \mathrm{B}$ (nuclear factor $\kappa B$ ) interagindo com os fatores associados ao receptor do fator de necrose tumoral (TNFR). A RIP2 mostra isoformas geradas por splicing alternativo, cujas funções e significados ainda não foram completamente esclarecidos. Essa proteína interage especificamente com o domínio CARD da caspase1, uma caspase pró-inflamatória, e ativa diretamente o padrão de sinalização ERK 1 / 2. Existem também evidências de sua participação em imunidade inata e adaptativa e em sinais iniciados por receptores de ambas as cascatas imunes: receptores toll-like (TLRs) e intracelulares NOD (nucleotide-binding and oligomerization domain) para imunidade inata, e receptores antígeno-específicos para imunidade adaptativa.

Nosso grupo identificou previamente uma variante do gene RIPK2 gerada por splicing alternativo (AY562996), combinando análise por ferramentas de bioinformática e pela reação em cadeia da polimerase via transcriptase reversa (RT-PCR) de sequências ORESTES (open reading frame expressed sequence tags). Essa nova variante apresenta remoção do exon 2 , que gera um código de parada prematuro e, consequentemente, um produto truncado com a perda dos domínios CARD e cinase.

A utilização de sítios de splicing alternativo difere entre tipos celulares, tecidos e fases do desenvolvimento e parece ser afetada por condições fisiológicas e estresse, tais como choque térmico, oxidativo e osmótico. Dado que as cinases RIP integram sinais de estresse extra e intracelulares e participam do início de diferentes cascatas de sinalização relacionadas tanto com proliferação como com morte celular, mudanças ambientais afetando sua expressão podem ter importantes implicações na fisiologia normal e em doenças. 


\section{MATERIAIS E MÉTODOS}

No presente estudo, a expressão de duas isoformas RIP2 derivadas de splicing alternativo foi investigada em células normais humanas procedentes de autópsia e em amostras de carcinoma epidermóide de cavidade oral. Para avaliar se a variante menor é conservada entre espécies, o cDNA de tumores de mama caninos foi amplificado utilizando condições de baixa estringência.

Com a finalidade de determinar se ambas as variantes são reguladas no nível pré-traducional por condições de estresse, sua expressão foi analisada sob exposição ao frio e ao calor e sob choque osmótico e acídico em três linhagens celulares tumorais humanas (FaDu/HTB-43, SiHa/HTB-35 and HeLa/CCL-2).

As linhagens celulares foram descongeladas e colocadas em meio MEM EARLE suplementado com soro fetal bovino, aminoácidos não essenciais, piruvato de sódio, penicilina e estreptomicina, sendo mantidas a $37^{\circ} \mathrm{C}$ em atmosfera de $5 \%$ de $\mathrm{CO}_{2}$. Quando a densidade celular mostrava-se próxima ao estado de confluência, o material dos frascos foi tripsinizado e subdividido em réplicas. Para choque ácido, as células foram submetidas, imediatamente após a troca do meio, a uma atmosfera com $\mathrm{CO}_{2} 10 \%$ por $24 \mathrm{~h}$ e $72 \mathrm{~h}$, e mantidas a $37^{\circ} \mathrm{C}$ em atmosfera de $\mathrm{CO}_{2} 5 \%$ por $24 \mathrm{~h}$ e $72 \mathrm{~h}$. O pH do meio foi rigorosa e repetidamente verificado a cada $6 \mathrm{~h}$. Para choque osmótico, as culturas foram alimentadas com meio MEM completo contendo glicerol 0,4M e 0,8M (soluto eletricamente neutro), enquanto os respectivos controles foram mantidos em ausência desse soluto. O bloqueio das culturas foi efetuado duas ou cinco horas após iniciado o experimento. Para choque térmico, as linhagens celulares foram submetidas, após a troca do meio, a temperaturas de $17^{\circ} \mathrm{C}$ ou $5^{\circ} \mathrm{C}$ por períodos de $64 \mathrm{~h}$, ou a 39$40^{\circ} \mathrm{C}$ por aproximadamente $3 \mathrm{~h}$. Os controles foram mantidos por períodos idênticos a $37^{\circ} \mathrm{C}$. Um segundo experimento de choque térmico foi realizado com dez réplicas, duas para cada condição.

\section{RESULTADOS E DISCUSSÃO}

Foi observado que as duas variantes RIP2 são expressas em todos os tecidos analisados e que a razão variante 1 / variante 2 é regulada em resposta à temperatura. A variante 2 também foi detectada em amostras de tecidos caninos, evidenciando sua conservação entre espécies relativamente distantes.

Como as cinases RIP possuem um papel crítico na integração de sinais de estresse, a elucidação dos fatores que atuam na regulação dessas proteínas é importante. 
A mudança de expressão das isoformas RIP pode levar a respostas opostas proliferação ou morte celular - com consequências importantes em diferentes condições patológicas. Seria interessante determinar o papel fisiológico de cada isoforma na adaptação ao estresse em células normais e tumorais. Entretanto, o desafio é integrar os achados in vitro e in vivo. 
Trabalho em fase de submissão

\section{TEMPERATURE REGULATES ALTERNATIVE SPLICING IN RIPK2}

\section{GENE}

Mancini $\mathrm{UM}^{1,2}$, Rodrigues $\mathbf{R V}^{1,2}$, Cunha $\mathrm{BR}^{1,2}$, Souza $\mathrm{CF}^{1,2}$, Head and Neck Genome Project GENCAPO ${ }^{4}$, Tajara $\mathrm{EH}^{1,2}$

${ }^{1}$ Departamento de Biologia Molecular, Faculdade de Medicina de São José do Rio Preto, FAMERP, São José do Rio Preto, SP, Brazil.

${ }^{2}$ Departamento de Genética e Biologia Evolutiva, Instituto de Biociências, USP, São Paulo, SP, Brazil

${ }^{4}$ http://ctc.fmrp.usp.br/clinicalgenomics/cp/group.asp. Complete authors list and addresses are also presented in the Appendix.

${ }^{\S}$ Corresponding author: Eloiza Helena Tajara, PhD, Department of Molecular Biology, School of Medicine/FAMERP, São José do Rio Preto, CEP 15090-000, SP, Brazil. Phone: +55 17 3201-5737, e-mail: tajara@famerp.br

\section{RUNNING TITLE}

Alternative splicing in $R I P K 2$ gene

\section{KEY WORDS}

Alternative splicing, RIPK2, temperature regulation, gene expression. 


\begin{abstract}
Receptor-interacting proteins (RIP) are a family of serine/threonine kinases which integrate extra- and intracellular stress signals caused by different factors, including infections, inflammation and DNA damage. Pro-survival, inflammatory and immune responses as well as death-inducing signaling pathways can all be initiated by the RIP kinases.

RIP2 is an important component of the nuclear factor $\kappa \mathrm{B}(\mathrm{NF}-\kappa \mathrm{B})$ activation by tumor necrosis factors and shows isoforms generated by alternative splicing, whose precise functions and significance remain to be determined. In the present study, the expression of RIPK2 transcripts was investigated in normal human tissues and in human and canine tumor samples. In order to determine if both variants are regulated at the pretranslational level in response to stress conditions, we analyzed their expression upon heat/cold exposure and acidic and osmotic shock in three human tumor cell lines.

We observed that both variants are expressed in all tissues analyzed and demonstrated that the variant 1/variant 2 ratio is regulated in response to temperature stress. As the RIP have a critical role in the integration of stress signals, the elucidation of factors involved in the regulation of these proteins is important. The change in RIP2 isoforms expression may lead to opposite responses - proliferation or cell death - with important consequences in different pathological conditions. It would be interesting to determine the physiological role of each isoform in the adaptation to stress in normal and tumor cells. However, the challenge is to integrate the findings in vitro and in vivo.
\end{abstract}




\section{INTRODUCTION}

Receptor-interacting proteins (RIP) are a family of serine/threonine kinases, which integrate extra and intracellular stress signals caused by different factors, including infections, inflammation, cellular differentiation and DNA damage. Pro-survival, inflammatory and immune responses as well as death-inducing signaling pathways can all be initiated by the RIP proteins (Meylan and Tschopp 2005).

RIP1, the best-characterized member of the RIP family, is an important component of the nuclear factor $\mathrm{kB}$ (NF-kB) activation by tumor necrosis factors (TNFs). TNFs and related cytokines initiate different signaling cascades that can result in opposite responses, both cell proliferation and cell death. Binding of TNF to its receptor leads to the recruitment and assembling of a signaling complex containing death domain proteins and the TNF receptor-associated factor 2 (TRAF2), triggering pro-apoptotic responses. The additional recruitment of RIP1 to this complex as well as its polyubiquitination through the lysine at position 63 (Lys63) of ubiquitin activate the mitogen-activated protein kinases (MAPKs) and the IkB kinase (IKK), which phosphorylates NF-kB inhibitors, targeting these proteins for proteasomal degradation. NF-kB transcription factors are thereby released and may induce expression of proinflammatory, prosurvival and immunomodulatory genes (Zhang, Kovalenko et al. 2000; Ea, Deng et al. 2006; O'Donnell, Legarda-Addison et al. 2007).

Besides its pro-survival role, RIP1 can act as a pro-death molecule, forming a complex with caspase-8 to initiate apoptosis (Lin, Devin et al. 1999; Kim, Choi et al. 2000; Martinon, Holler et al. 2000; O'Donnell, Legarda-Addison et al. 2007). RIP1 interacts with RIP3, another member of the RIP family, which promotes apoptosis in various cell types when overexpressed (Sun, Yin et al. 2002).

RIP4, unlike RIP3, induces the activation of NF-kB and AP-1 pathways when overexpressed. This member of the RIP kinase family is a modulator of keratinocyte differentiation and, as RIP5, is characterized by the presence of ankyrin repeats in their Cterminal domain (Meylan, Martinon et al. 2002; Zha, Zhou et al. 2004; Meylan and Tschopp 2005; Adams, Pankow et al. 2007). RIP6 (or LRRK1) and RIP7 (or LRRK2) are additional RIP kinases that have a leucine-rich repeat (LRR) motif and may be involved in pathogen-, damage- or stress-associated molecular patterns (Festjens, Vanden Berghe et al. 2007). 
RIP2 (also called RICK or CARDIAK), like other RIPs, activates NF-kB, interacting with the TNFR-associated factors. This RIP specifically interacts with the CARD of caspase-1, a pro-inflammatory caspase, and directly activates ERK1/2 signaling (Inohara, del Peso et al. 1998; Thome, Hofmann et al. 1998; Navas, Baldwin et al. 1999). Some reports claim the participation of RIP2 in innate and adaptive immunity, and in transducing signals from receptors of both immune cascades: Toll-like receptors (TLRs) and nucleotide-binding and oligomerization domain (NOD) intracellular receptors for innate immunity and antigen-specific receptors for adaptive immunity (Chin, Dempsey et al. 2002; Kobayashi, Inohara et al. 2002). Otherwise, the studies of Park et al (Park, Kim et al. 2007) and Hall et al (Hall, Wilhelm et al. 2008) indicated that the absence of RIP2 causes reduced cytokine production and are defective in their responses to NOD but does not affect $\mathrm{T}$ cell proliferation, $\mathrm{T}$ helper differentiation or TLR responses. In addition, RIP2 has been demonstrated to have an important role for the healing process, either as a regulator of keratinocyte proliferation, migration or differentiation (Adams, Valchanova et al. 2010).

Similar to RIP1 in the TNF signaling cascade, Lys63-linked polyubiquitination of RIP2 induces NF-kB activation after NOD stimulation. The polyubiquitin chains are linked at lysine 209 in RIP2 kinase domain (Hasegawa, Fujimoto et al. 2008) whereas, in RIP1, are linked at lysine 377, in an intermediate region between the N-terminal kinase and Cterminal death domain (Ea, Deng et al. 2006; Li, Kobayashi et al. 2006). In NOD signaling pathway, the interaction of RIP2 and NEMO, a regulatory subunit of IKK, is also essential for NF-kB activation (Inohara, Koseki et al. 2000). Recently, Clark and collaborators (Clark, Marinis et al. 2008) demonstrated that MAP3K4, a MAPK kinase kinase that is a major mediator of environmental stress, sequesters RIP2 from the NOD signaling inhibiting NF-kB cascades.

We previously described a new alternative splicing variant of the RIPK2 gene (AY562996), using a combined bioinformatic and reverse transcription polymerase chain reaction (RT-PCR) analysis of open reading frame expressed sequence tags (ORESTES) (Mancini and Tajara). This new variant presents skipping of exon 2 and is characterized by extensive truncation of the the $\mathrm{C}$-terminus resulting in a frameshift that generates a premature termination codon (PTC). Recently, Krieg et al (2009) (Krieg, Le Negrate et al. 2009) showed the loss of the CARD domain and intermediate region as well as truncation of the kinase domain make this shortened form RIPK2 unable to activate NF-KB and caspase pathways, and loss of autophosphorylation and kinase activity. 
The use of alternative splice sites may differ among cell types, tissues and phases of development (Clarke, Jordan et al. 2000; Sun, Yin et al. 2002; Zeng, Sharpe et al. 2006) and has been shown to be affected by physiologic and stress conditions, such as heat shock, oxidative and osmotic stress (Shen, Beall et al. 1993; Takechi, Hosokawa et al. 1994; Tomasini, Samir et al. 2001; Hashimoto, Zhang et al. 2002; Gray, Iglesias et al. 2003; Matsuzaki, Manabe et al. 2004; Nurmi, Puolakkainen et al. 2005; Wakasugi, Nakano et al. 2005; Bond, Patel et al. 2006; Kim and Gladyshev 2006; Fiol, Mak et al. 2007). For example, Fujikake and collaborators (Fujikake, Nagai et al. 2005) identified three new variants of the Drosophila heat shock transcription factor gene $(H s f)$ regulated in response to heat/cold stress. In mouse, one alternatively spliced mRNA of the HSP47 (heat shock protein 47) gene is temperature-induced (Takechi, Hosokawa et al. 1994). A similar event was observed for the "readthrough" transcript (type R) of the acetylcholinesterase gene (Ache) in mouse neuroblastoma N18TG2 cells (Perrier, Salani et al. 2005).

In humans, an interesting case of temperature-dependent alternative splicing was observed in fibroblasts of a patient with Ehlers-Danlos Syndrome type VII (Weil, D'Alessio et al. 1989). The patient showed a mutation in the last nucleotide of exon 6 of the COL1A1 gene, which produced an aberrant spliced transcript not detectable at $31^{\circ} \mathrm{C}$ but present at $39^{\circ} \mathrm{C}$. The insertion of a cryptic exon in the neurofibromatosis type $1 \mathrm{mRNA}$ induced by cold-shock conditions was also observed by Ars and collaborators (Ars, Serra et al. 2000).

RIPK1, 2, 3 and 5 genes show variants generated by alternative splicing of the primary transcripts whose precise functions and significance remain to be determined. Since RIP kinases integrate extra and intracellular stress signals and initiate different signaling cascades that can result both in cell proliferation and cell death, environmental changes may affect their expression with important implications.

In the present study, the expression of two RIPK2 isofoms was investigated in normal and tumor cells. In order to determine if both variants are regulated at the pretranslational level in response to stress conditions, we analyzed their expression upon heat/cold exposure and acidic and osmotic shock in human tumor cell lines. 


\section{Samples}

Nine samples of normal human tissues removed at autopsy (brain, testis, heart, lung, stomach, kidney, larynx, liver and tongue) and samples from 32 patients with squamous cell carcinoma of the oral cavity and 4 dogs (Canis lupus familiaris) with mammary tumors (matched tumor/surgical margins) were used to evaluate the expression of two splicing variants of the RIPK2 gene using RT-PCR and quantitative PCR.

For the stress experiments, we utilized the human ATCC cell lines HeLa/CCL-2, (adenocarcinoma of the cervix), FaDu/HTB-43 (squamous cell carcinoma of the pharynx), and $\mathrm{SiHa} / \mathrm{HTB}-35$ (squamous cell carcinoma of the cervix). All three cell lines were cultured in Modified Eagle's Medium (Cultilab, Campinas, Brazil) supplemented with $10 \%$ fetal bovine serum (Cultilab), 10mM of non-essential amino acids (Invitrogen), $0.11 \mathrm{~g} / \mathrm{L}$ of sodium pyruvate, $100 \mathrm{units} / \mathrm{ml}$ penicillin (Cultilab), and $90 \mu \mathrm{g} / \mathrm{ml}$ streptomycin (Cultilab), in a humidified atmosphere with $5 \% \mathrm{CO}_{2}$ at $37^{\circ} \mathrm{C}$.

The study protocol was approved by the National Committee of Ethics in Research (CONEP 1763/05, 18/05/2005) and informed consent was obtained from all patients enrolled.

\section{Heat, osmotic and acidic shock}

Prior to stress treatment, replicas from each cell line were allowed to grow to $80-90 \%$ confluence. The medium was replaced with $15 \mathrm{~mL}$ of fresh medium at 0 hour. For the heat shock experiments, cultures were maintained at $40^{\circ} \mathrm{C}$ for $3 \mathrm{~h}$, and at $17^{\circ} \mathrm{C}$ or $5^{\circ} \mathrm{C}$ for $64 \mathrm{~h}$. Osmotic shock was achieved by incubation of cell line cultures in medium containing $0.4 \mathrm{M}$ or $0.8 \mathrm{M}$ ultrapure glycerol (hypertonic stress) for 2 or $5 \mathrm{~h}$ at $37^{\circ} \mathrm{C}$. Acidic shock was performed by maintaining the cultures in an atmosphere with elevated $\mathrm{CO}_{2}\left(10 \% \mathrm{CO}_{2}\right)$ for $24 \mathrm{~h}$ or $72 \mathrm{~h}$. Ten replicas were cultured under each stress condition, and ten control replicas were cultured without addition of glycerol, in a humidified atmosphere with 5\% $\mathrm{CO}_{2}$ at $37^{\circ} \mathrm{C}$ for the same time periods.

Cells were immediately lysed after the incubation period by adding TRIzol (Invitrogen), and stored at $-80^{\circ} \mathrm{C}$ until RNA extraction. 
Total RNAs from tissue samples and cell lines were obtained using TRIzol reagent and and treated with DNase. One microgram of total RNA was converted to cDNA using the ThermoScript ${ }^{\mathrm{TM}}$ RT-PCR System or SuperScript ${ }^{\mathrm{TM}}$ III Reverse Transcriptase (Invitrogen), according to the manufacturer's instructions. Integrity of the RNA was confirmed by agarose gel electrophoresis, and the concentration was determined by obtaining the ratio of absorbance values at 260 and $280 \mathrm{~nm}$, following standard procedures.

\section{Detection of RIPK2 variants by semiquantitative PCR and sequencing}

The PCR amplification of both longer and shorter RIPK2 variants was performed using the oligonucleotides 5'-CGCCTCTGGCACTGTGTCGT-3' (sense) and 3'CGTGACTGTGAGAGGGACAT-3' (anti-sense). The total reaction volume was $25 \mu \mathrm{l}$ and contained 1X PCR buffer, $1 \mathrm{mM} \mathrm{MgCl} 2,2 \mu \mathrm{M}$ of each RIPK2 primer, $2 \mu \mathrm{M}$ of GAPDH primers, $5 \mathrm{mM}$ dNTPs mix, $1 \mathrm{U}$ Taq DNA polymerase (Invitrogen) and 50ng of cDNA. After pre-incubation for $5 \mathrm{~min}$ at $94^{\circ} \mathrm{C}$ (initial denaturation), amplification was carried out through 35,28 or 21 cycles at $94^{\circ} \mathrm{C}$ for $50 \mathrm{~s}, 58^{\circ} \mathrm{C}$ for $40 \mathrm{~s}, 72^{\circ} \mathrm{C}$ for $50 \mathrm{~s}$, and $72^{\circ} \mathrm{C}$ for 10 min, using a thermal cycler (9700 GeneAmp PCR System - Applied Biosystems, Foster City, CA, USA). PCR amplification of the endogenous control gene, glyceraldehyde-3phosphate dehydrogenase $(G A P D H)$, was carried out using sense (5'CTGCACCACCAACTGCTTA-3' or 5'- ACCCACTCCTCCACCTTTGA-3') and antisense (5'-CTAGACGGCAGGTCAGGTC-3' or 5'-CTGTTGCTGTAGCCAAATTCGT3') primers. The PCR products from RIPK2 variant 1 (457 bp), variant 2 (303 bp), and GAPDH (296 bp and $101 \mathrm{bp)}$ were separated on 2\% agarose gels in the presence of ethidium bromide and quantified by an imager system (EDAS 290, Kodak, New Haven, CT). The PCR bands were cut out of the agarose gel and directly sequenced in both directions with sense and antisense primers, using a 377 ABI Prism Sequencer (Applied Biosystems). The sequences were analyzed using BLAST similarity search against a Nucleotide Database (www.ncbi.nlm.nih.gov/BLAST/).

\section{Splice variant-specific real time PCR}

The expression of RIPK2 variant 1 and variant 2 following stress treatment of FaDu cells was investigated by real time PCR. The reaction was performed in quadruplicate using an ABI Prism 7500 Sequence Detection System (Applied Biosystems). The primers were manually designed using the following parameters: 19-24 bp length, 30-70\% GC content and a short amplicon size (66-104 bp), as follows, RIPK2 variant 1, sense (5'- 
AGAAGCTGAAATTTTACACAAAGC-3')

$\begin{array}{ccc}\text { and } & \text { antisense } & \left(5^{\prime}-\right. \\ \text { RIPK2 variant } & 2, \quad \text { sense } & \left(5^{\prime}-\right. \\ \text { and } & \text { antisense } & \left(5^{\prime}-\right. \\ \text { GAPDH, } & \text { sense } & \left(5^{\prime}-\right. \\ \text { and } & \text { antisense } & \left(5^{\prime}-\right. \\ \text { TUB6A, } & \text { sense } & \left(5^{\prime}-\right. \\ \text { and } & \text { antisense } & \left(5^{\prime}-\right.\end{array}$

CCATTTGGCATGTATTCAGTAAC-3');

TGCTCGACAGAAAACTGAATATC-3')

AAGGAGGAGTCATATTGTGCAG-3');

ACCCACTCCTCCACCTTTGA-3')

CTGTTGCTGTAGCCAAATTCGT-3');

TCAACACCTTCTTCAGTGAAACG-3')

$\left(5_{1}-\right.$

AGTGCCAGTGCGAACTTCATC-3'); ACTB, sense (5'-GGCACCCAGCACAATGAAG-

3') and antisense (5'-CCGATCCACACGGAGTACTTG-3'). All primers were purchased from Invitrogen. Briefly, the reactions were carried out in a total volume of $20 \mu \mathrm{l}$, with 10 $\mu \mathrm{l}$ of Power SYBR Green PCR Master Mix (Applied Biosystems), $250 \mathrm{nM}$ of each primer and $10 \mathrm{ng}$ cDNA. The PCR conditions were $50^{\circ} \mathrm{C}$ for $2 \mathrm{~min}, 95^{\circ} \mathrm{C}$ for $10 \mathrm{~min}$, followed by 40 cycles of $95^{\circ} \mathrm{C}$ for $15 \mathrm{sec}, 58^{\circ} \mathrm{C}$ for $10 \mathrm{sec}, 60^{\circ} \mathrm{C}$ for $1 \mathrm{~min}$. Following the PCR, dissociation curve analysis was performed to confirm the desired single gene product.

The gene expression stability over different samples was analyzed using the geNorm software (http://medgen.ugent.be/ jvdesomp/genorm). Each transcript level was normalized by division with the expression values of $G A P D H, A C T B$ and TUBA6, used as internal controls.

The transcript level was calculated using the $2^{-\Delta \Delta \mathrm{Ct}}$ method (Livak and Schmittgen 2001). The fold difference (relative abundance) was calculated using the formula $2^{-\triangle \triangle C T}$ and was plotted as means $\pm \mathrm{SD}$, with $n=3$ technical replicates. Fold differences of $>3$ were considered to be significant.

All reactions were performed with a negative control. One sample without treatment was chosen to be used as the calibrator control for the reactions. Experiments were repeated whenever the coefficient of variation was higher than 5\%. After each reaction, the products were analyzed on a $2 \%$ agarose gel stained with ethidium bromide.

\section{RESULTS}

\section{Identification and Expression Patterns of RIPK2 variants}

The open reading frame expressed sequence tags (ORESTES, (Dias Neto, Correa et al. 2000) generated by the Human Cancer Genome Project (HCGP); (Camargo, Samaia et al. 2001; Brentani, Caballero et al. 2003); were matched to the RefSeq and mRNA public data sets (www.ncbi.nlm.nih.gov). Genomic mapping of the ORESTES sequences revealed the existence of a putative new RIPK2 splice variant. RT-PCR and cDNA sequencing were 
performed to confirm the splicing event, using normal and tumor tissues. This approach revealed the expression of both longer RIPK2 variant 1 (NM_003821) and shorter variant 2 (AY562996) in different samples. The latter is generated by skipping of exon 2 (154bp), which alters the reading frame, producing several premature stop codons.

Normal tissue samples from brain, testis, heart, lung, stomach, kidney, larynx, liver and tongue, and matched tumor/surgical margins samples from 32 patients with oral cancer co-expressed RIPK2 variants 1 and 2 (Figure 1A and B). The co-expression of both isoforms was reinforced by database analysis (UCSC Genome Browser http://genome.ucsc.edu/) of ESTs covering the exon 2 of RIPK2. This analysis showed the skipping of exon 2 in 33 of the 80 ESTs covering this transcript region. To investigate whether splice variant 2 is conserved across species, we amplified cDNA from canine mammary tumors by using low stringent conditions. Again, a putative splice variant was detected (Figure 1C).

\section{Splicing patterns of RIPK2 under stress conditions}

To investigate whether alternative splicing of RIPK2 is induced or inhibited by stress conditions, three cell lines ( $\mathrm{FaDu}, \mathrm{SiHa}$ and $\mathrm{HeLa})$ were exposed to severe heat shock $\left(40^{\circ} \mathrm{C}, 17^{\circ} \mathrm{C}\right.$ or $5^{\circ} \mathrm{C}$ ), osmotic shock (hypertonic medium) or acidic shock (atmosphere of $10 \% \mathrm{CO}_{2}$ ). Only heat shock altered the splicing pattern. The semi-quantitative RT-PCR results showed an increase in the transcription of variant 1 at $40^{\circ} \mathrm{C}$ and an increase in the transcription of variant 2 at $17^{\circ} \mathrm{C}$ compared to that at $37^{\circ} \mathrm{C}$ (Figure $2 \mathrm{~B}$ ). In all replicas of the Fadu cell line at $40^{\circ} \mathrm{C}$, the result was confirmed by quantitative PCR, and in most replicas at $17^{\circ} \mathrm{C}$, variant 2 showed higher expression than variant 1 (Figure $2 \mathrm{~A}$ ). These results suggest that alternatively spliced exon 2-containing mRNA may be transcribed more efficiently at higher temperatures than the variant without exon 2.

\section{DISCUSSION}

In the present study, we detected the expression of two RIPK2 variants in normal tissues and tumor cells. We found evidence that transcript 2 is conserved across species, since it was also detected in canine mammary tissue. At the protein level, a western blot band, which may correspond to isoform 2, was detected in the samples analyzed.

We observed a shift in the expression of RIPK2 variants 1 and 2 as a response to temperature stress in vitro. Hyperthermia accompanies some pathophysiological processes, such as infection, injury and inflammation, and may lead to enhancement of immune 
responses to the causal stimuli. A beneficial effect of hyperthermia has also been observed when used therapeutically together with cancer treatment (Wust, Hildebrandt et al. 2002; Yoo and Lee 2007). However, the molecular mechanisms that mediate the effects of hyperthermia are not completely known so far.

Yan and collaborators (Yan, Xiu et al. 2007) found evidence that hyperthermia induces TLR expression and TLR signaling-mediated activation of NF- $\kappa \mathrm{B}$ and MAPK pathways, resulting in increased synthesis of pro- and anti-inflammatory cytokines. Zhao et al (Zhao, An et al. 2007) also observed TLR activation and significantly increased cytokine production when TLR stimulation was accompanied by a hyperthermia pretreatment. These data suggest that fever may modulate innate immune responses by TLR pathway and, although the role of RIP2 in this signaling remains controversial (Chin, Dempsey et al. 2002; Kobayashi, Inohara et al. 2002; Park, Kim et al. 2007; Hall, Wilhelm et al. 2008), provide a possible link to RIPK2 expression changes depending on the temperature variation.

RIP2 integrates extra and intracellular stress signals and is an important component of the NF- $\mathrm{KB}$ signaling cascade, transducing signals from innate immune system proteins, including cytoplasmic NOD proteins, which are involved in detecting pathogens in intracellular compartments. In addition, RIP2 has been suggested to be required for T-cellreceptor signaling and therefore may also participate of the adaptive immune response (Kobayashi, Inohara et al. 2002).

Hasegawa and collaborators (Hasegawa, Fujimoto et al. 2008) demonstrated that Lys63-linked polyubiquitination at Lys209 within the kinase domain of RIP2 is essential for NOD-mediated NF-kB activation. The authors also showed that the interaction between NEMO and the intermediate region spanning residues 293-319 of RIP2 is required for NOD signaling. Otherwise, the residue critical for kinase activity of RIP2 (Lys47) is important but not essential for NF-kB activation (Inohara, del Peso et al. 1998; Inohara, Koseki et al. 2000) and apparently does not participate in polyubiquitination and interaction with NEMO. The kinase domain may mediate other functions, such as regulation of ERKs, p38 kinases, and own degradation (Navas, Baldwin et al. 1999; Chin, Dempsey et al. 2002; Hasegawa, Fujimoto et al. 2008). Considering these data, it is reasonable to suppose that isoform 2 of RIP2 may exhibit some impaired functions, other than polyubiquitination and interaction with NEMO, since its kinase domain is partially deleted. 
In the present study, RIPK2 variants 1 and 2 were observed in all normal and tumor tissues investigated, including human and canine samples. Variant 2 showed a tendency to have increased expression at low temperatures than variant 1, whereas the opposite occurred at $40^{\circ} \mathrm{C}$.

This variability - a shift in the expression of RIPK2 variants 1 and 2 as a response to temperature changes - suggests that stress signals caused by conditions such as infections and inflammation may affect the expression and splicing of RIPK2. We hypothesize that, under stress conditions, a putative mechanism would induce higher or lower expression of the exon 2-containing RIPK2 product, which clearly affects the sequence of the encoded protein. If isoform 2 is a non-functional protein, the balance of isoforms 1 and 2 would change, with consequences on signaling both NF-kB and caspase pathways related to RIP2. For instance, hyperthermia would increase the turnover rate of RIP2 or affect ERK pathways, whereas hypothermia might trigger proapoptotic responses. However, this hypothesis obviously requires experimental confirmation.

Recently, Dasgupta and collaborators (Dasgupta, Agarwal et al. 2008) described a Cterminal fragment of another member of RIP family, RIP1, which can activate signaling events, including NF-kB and TNF pathways, and consequently, induce survival and apoptotic responses. They concluded that short RIP1 affects the long isoform levels and may represent a new regulation mechanism. Albeit exhibiting some differences, RIP1 and 2 participate in the same regulatory net and are probably derived from a common ancestry. Therefore, it is tempting to hypothesize that short RIP2 may reduced production of long RIP2 under different conditions.

As RIP kinases play a critical role in integrating stress signals, the elucidation of the factors that take part in the regulation of these proteins is of major importance. The change in expression of RIP isoforms may lead to opposite responses - cell proliferation or cell death - with important consequences in different pathological conditions. It would be interesting to determine the physiological roles of each isoform for stress adaptation of normal and cancer cells. However, the challenge will be to link in vitro and in vivo findings. 


\section{ACKNOWLEDGMENT}

The authors acknowledge support from FAPESP/Fundação de Amparo à Pesquisa do Estado de São Paulo (Grants 04/12054-9 and 03/07802-3), Conselho Nacional de Desenvolvimento Científico e Tecnológico/CNPq (Grant 401043/05-3) and LICR/Ludwig Institute for Cancer Research.

\section{APPENDIX}

The GENCAPO (Head and Neck Genome Project) authors are the following:

Alves $\mathrm{JL}^{\mathrm{h}}$, Amar $\mathrm{A}^{\mathrm{h}}$, Arap SS ${ }^{\mathrm{f}}$, Araújo-Filho $\mathrm{V}^{\mathrm{f}}$, Barbieri $\mathrm{RB}^{\mathrm{h}}$, Brandão LG ${ }^{\mathrm{f}}$, Brandão $\mathrm{RM}^{\mathrm{k}}$, Canto $\mathrm{AL}^{\mathrm{d}}$, Carmona-Raphe $\mathrm{J}^{\mathrm{b}}$, Carvalho $\mathrm{A}^{\mathrm{h}}$, Carvalho-Neto $\mathrm{PB}^{\mathrm{h}}$, Cerione $\mathrm{M}^{\mathrm{e}}$, Cernea $\mathrm{CR}^{\mathrm{f}}$, Chedid $\mathrm{H}^{\mathrm{h}}$, Chiappini $\mathrm{PBO}^{\mathrm{h}}$, Cominato $\mathrm{ML}^{\mathrm{e}}$, Correa PMS ${ }^{\mathrm{d}}$, Correia $\mathrm{LA}^{\mathrm{h}}$, Costa $\mathrm{A}^{1}$, Curioni $\mathrm{OA}^{\mathrm{h}}$, Cury $\mathrm{PM}^{\mathrm{g}}$, de Carvalho $\mathrm{MB}^{\mathrm{h}}$, Dias Neto $\mathrm{E}^{\mathrm{c}}$, Dias $\mathrm{THG}^{\mathrm{c}}$, Durazzo $\mathrm{M}^{\mathrm{f}}$, Dutra $\mathrm{RL}^{\mathrm{h}}$, Ferraz $\mathrm{AR}^{\mathrm{f}}$, Figueiredo DLA ${ }^{\mathrm{i}}$, Figueiredo $\mathrm{RO}^{1}$, Fortes $\mathrm{CS}^{1}$, Franzi $\mathrm{SA}^{\mathrm{h}}$, Fukuyama $\mathrm{EE}^{\mathrm{e}}$, Gazito $\mathrm{D}^{\mathrm{h}}$, Góis-Filho $\mathrm{JF}^{\mathrm{e}}$, Gutierres $\mathrm{AP}^{\mathrm{h}}$, Henriques $\mathrm{S}^{\mathrm{h}}$, Inamine $\mathrm{R}^{1}$, Kaneto $\mathrm{CM}^{\mathrm{k}}$, Lehn $\mathrm{CN}^{\mathrm{h}}$, Leopoldino $\mathrm{AM}^{\mathrm{o}}$, Lisoni $\mathrm{FCCR}^{\mathrm{b}}$, López $\mathrm{RVM}^{1}$, Macarenco $\mathrm{R}^{\mathrm{d}}$, Magalhães $\mathrm{RP}^{\mathrm{f}}$, Mamede $\mathrm{RCM}^{\mathrm{i}}$, Mancini $\mathrm{UM}^{\mathrm{b}}$, Martins $\mathrm{GS}^{\mathrm{e}}$, Meneses $\mathrm{C}^{\mathrm{d}}$, Mercante $\mathrm{AMC}^{\mathrm{h}}$, Michaluart-Junior $\mathrm{P}^{\mathrm{f}}$, Montenegro $\mathrm{FLM}^{\mathrm{f}}$, Moreira-Filho $\mathrm{CA}^{\mathrm{a}}$, Mota $\mathrm{AJ}^{\mathrm{d}}$, Moyses RA ${ }^{\mathrm{f}}$, Nóbrega $\mathrm{FG}^{\mathrm{d}}$, Nóbrega $\mathrm{MP}^{\mathrm{d}}$, Nunes $\mathrm{FD}^{\mathrm{m}}$, Ojopi $\mathrm{EPB}^{\mathrm{c}}$, Okamoto $\mathrm{OK}^{\mathrm{n}}$, Oliveira $\mathrm{FB}^{\mathrm{g}}$, Oliveira MIS ${ }^{\mathrm{h}}$, Paiva $\mathrm{R}^{\mathrm{e}}$, Paraventi $\mathrm{C}^{\mathrm{f}}$, Pinheiro $\mathrm{DG}^{\mathrm{k}}$, Polachini $\mathrm{GM}^{\mathrm{b}}$, Ramos $\mathrm{O}^{\mathrm{f}}$, Rapoport $\mathrm{A}^{\mathrm{h}}$, Rodini $\mathrm{CO}^{\mathrm{m}}$, Rodrigues $\mathrm{AN}^{1}$, Rodrigues $\mathrm{RV}^{\mathrm{b}}$, Santos $\mathrm{ARD}^{\mathrm{k}}$, Santos $\mathrm{M}^{\mathrm{h}}$, Santos $\mathrm{VPP}^{\mathrm{h}}$, Secco $L^{\mathrm{e}}$, Serafini $\mathrm{LN}^{\mathrm{j}}$, Settani $F^{\mathrm{e}}$, Severino $\mathrm{P}^{\mathrm{a}}$, Silva $A M A^{\mathrm{h}}$, Silva $A M N^{\mathrm{h}}$, Silva $C^{\mathrm{f}}$, Silva $\mathrm{IT}^{\mathrm{k}}$, Silva $\mathrm{MJ}^{\mathrm{e}}$, Silva-Filho $\mathrm{GB}^{\mathrm{f}}$, Silva-Junior $\mathrm{WA}^{\mathrm{k}}$, Silveira $\mathrm{NJF}^{\mathrm{p}}$, Smith $\mathrm{RB}^{\mathrm{f}}$, Souza $\mathrm{SCOM}^{\mathrm{m}}$, Souza $\mathrm{TB}^{\mathrm{h}}$, Stabenow $\mathrm{E}^{\mathrm{f}}$, Tajara $\mathrm{EH}^{\mathrm{b}}$, Takamori $\mathrm{JT}^{\mathrm{h}}$, Tarlá MVC ${ }^{\mathrm{k}}$, Tavares $\mathrm{MR}^{\mathrm{f}}$, Teixeira $\mathrm{AP}^{\mathrm{b}}$, Turcano $\mathrm{R}^{\mathrm{f}}$, Valentim $\mathrm{PJ}^{\mathrm{e}}$, Vidotto $\mathrm{A}^{\mathrm{b}}$, Volpi $\mathrm{EM}^{\mathrm{f}}$, Wanderley $\mathrm{AC}^{\mathrm{h}}$, WünschFilho $\mathrm{V}^{1}$, Xavier $\mathrm{FCA}^{\mathrm{m}}$, Yamagushi $\mathrm{F}^{\mathrm{e}}$, Zago $\mathrm{MA}^{\mathrm{q}}$.

Affiliations: ${ }^{a}$ Instituto de Ensino e Pesquisa Albert Einstein, São Paulo, SP; ${ }^{b}$ Departamento de Biologia Molecular, Faculdade de Medicina de São José do Rio Preto, SP; ' Instituto de Psiquiatria, Faculdade de Medicina, USP, São Paulo, SP; ${ }^{\mathrm{d}}$ Instituto de

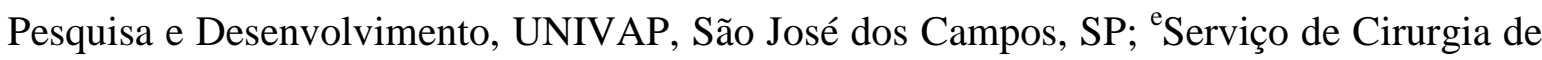
Cabeça e Pescoço, Instituto do Câncer Arnaldo Vieira de Carvalho, São Paulo, SP; ${ }^{\mathrm{f}}$ Departamento de Cirurgia de Cabeça e Pescoço, Faculdade de Medicina, USP, São Paulo, SP; ${ }^{\mathrm{g}}$ Departamento de Patologia, Faculdade de Medicina de São José do Rio Preto, SP;

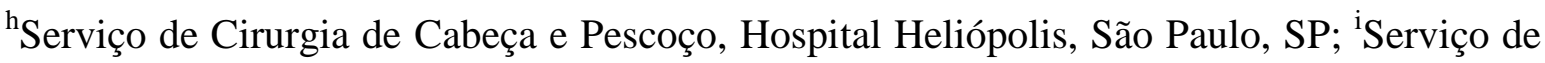


Cirurgia de Cabeça e Pescoço, Faculdade de Medicina de Ribeirão Preto, USP, SP; ${ }^{\mathrm{j} D e p a r t a m e n t o ~ d e ~ P a t o l o g i a, ~ F a c u l d a d e ~ d e ~ M e d i c i n a ~ d e ~ R i b e i r a ̃ o ~ P r e t o, ~ U S P, ~ S P ; ~}$ ${ }^{k}$ Departamento de Genética, Faculdade de Medicina de Ribeirão Preto, USP, SP; l'Departamento de Epidemiologia, Faculdade de Saúde Pública, USP, São Paulo, SP; ${ }^{\mathrm{m}}$ Departamento de Estomatologia, Faculdade de Odontologia da USP, São Paulo, SP; ${ }^{\mathrm{n}}$ Departamento de Neurologia/Neurocirurgia, UNIFESP, São Paulo, SP; ${ }^{\circ}$ Departamento de Análises Clínicas, Toxicológicas e Bromatológicas, Faculdade de Ciências Farmacêuticas de Ribeirão Preto, USP, SP; ${ }^{\mathrm{P} C i e ̂ n c i a s ~ d a ~ C o m p u t a c ̧ a ̃ o, ~ U N I V A P, ~ S a ̃ o ~ J o s e ́ ~ d o s ~ C a m p o s, ~}$ SP; ${ }^{9}$ Departamento de Clínica Médica, Faculdade de Medicina de Ribeirão Preto, USP, SP; Brasil. 

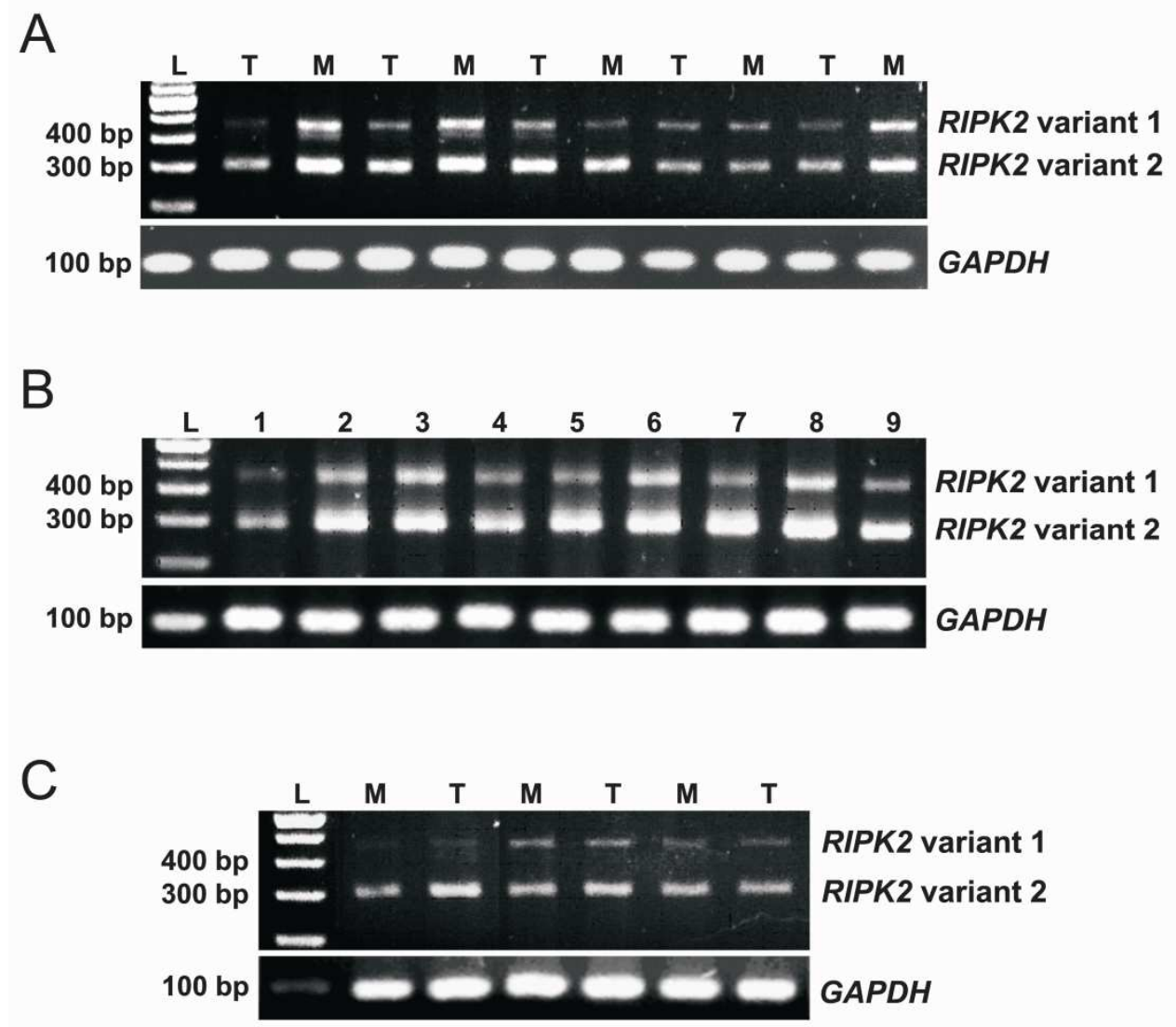

Figure 1. Expression of RIPK2 $\mathrm{mRNA}$ and RIP2 protein in normal and tumor tissues. RT-PCR products from RIPK2 variant 1 (456bp), variant 2 (302bp), and GAPDH (305 bp) in (A) samples from patients with oral cancer, $(\mathbf{B})$, normal human tissues and $(\mathbf{C})$ canine mammary tumor samples. $\mathrm{T}=$ tumor; $\mathrm{M}=$ surgical margin; 1=brain; 2=testis; 3=heart; 4=lung; 5=stomach; 6=kidney; 7=larynx; 8=liver; 9=tongue; $\mathrm{L}=100 \mathrm{bp}$ fragment size marker. GAPDH mRNA was included as a control. 


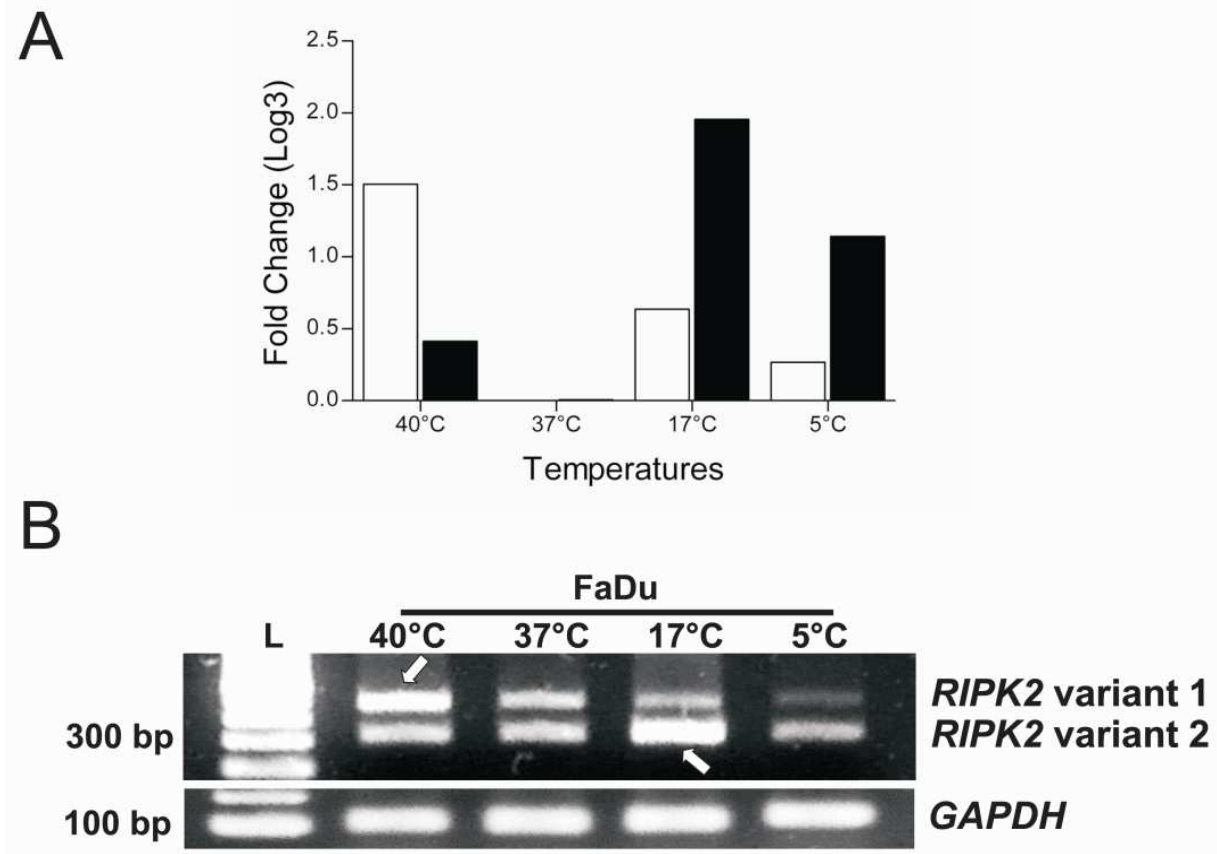

Figure 2. A. Splicing patterns of RIPK2 under temperature stress. RIPK2 splice variants in FaDu cell line cultures maintained at $40^{\circ} \mathrm{C}$ for $3 \mathrm{~h}$ and at $17^{\circ} \mathrm{C}$ or $5^{\circ} \mathrm{C}$ for $64 \mathrm{~h}$. A. Quantification of RIPK2 splice variant 1 (white) and 2 (black) expression by real time PCR. B. RT-PCR products from RIPK2 variant 1 (456 bp), variant 2 (302 bp), and GAPDH (101 bp). Arrows indicate shifted bands. 


\section{REFERENCES}

Adams, S., S. Pankow, et al. (2007). "Regulation of NF-kappaB activity and keratinocyte differentiation by the RIP4 protein: implications for cutaneous wound repair." J Invest Dermatol 127(3): 538-44.

Adams, S., R. S. Valchanova, et al. (2010). "RIP2: a novel player in the regulation of keratinocyte proliferation and cutaneous wound repair?" Exp Cell Res 316(5): 728-36.

Ars, E., E. Serra, et al. (2000). "Cold shock induces the insertion of a cryptic exon in the neurofibromatosis type 1 (NF1) mRNA." Nucleic Acids Res 28(6): 1307-12.

Bond, C. E., P. Patel, et al. (2006). "Astroglia up-regulate transcription and secretion of 'readthrough' acetylcholinesterase following oxidative stress." Eur J Neurosci 24(2): 381-6.

Brentani, H., O. L. Caballero, et al. (2003). "The generation and utilization of a canceroriented representation of the human transcriptome by using expressed sequence tags." Proc Natl Acad Sci U S A 100(23): 13418-23.

Camargo, A. A., H. P. Samaia, et al. (2001). "The contribution of 700,000 ORF sequence tags to the definition of the human transcriptome." Proc Natl Acad Sci U S A 98(21): 12103-8.

Chin, A. I., P. W. Dempsey, et al. (2002). "Involvement of receptor-interacting protein 2 in innate and adaptive immune responses." Nature 416(6877): 190-4.

Clark, N. M., J. M. Marinis, et al. (2008). "MEKK4 sequesters RIP2 to dictate NOD2 signal specificity." Curr Biol 18(18): 1402-8.

Clarke, L. A., P. Jordan, et al. (2000). "Cell type specificity in alternative splicing of the human mismatch repair gene hMSH2." Eur J Hum Genet 8(5): 347-52. 
Dasgupta, M., M. K. Agarwal, et al. (2008). "Transposon-based mutagenesis identifies short RIP1 as an activator of NFkappaB." Cell Cycle 7(14): 2249-56.

Dias Neto, E., R. G. Correa, et al. (2000). "Shotgun sequencing of the human transcriptome with ORF expressed sequence tags." Proc Natl Acad Sci U S A 97(7): 3491-6.

Ea, C. K., L. Deng, et al. (2006). "Activation of IKK by TNFalpha requires site-specific ubiquitination of RIP1 and polyubiquitin binding by NEMO." Mol Cell 22(2): 245-57.

Festjens, N., T. Vanden Berghe, et al. (2007). "RIP1, a kinase on the crossroads of a cell's decision to live or die." Cell Death Differ 14(3): 400-10.

Fiol, D. F., S. K. Mak, et al. (2007). "Specific TSC22 domain transcripts are hypertonically induced and alternatively spliced to protect mouse kidney cells during osmotic stress." FEBS J 274(1): 109-24.

Fujikake, N., Y. Nagai, et al. (2005). "Alternative splicing regulates the transcriptional activity of Drosophila heat shock transcription factor in response to heat/cold stress." FEBS Lett 579(17): 3842-8.

Gray, S. G., A. H. Iglesias, et al. (2003). "Modulation of splicing events in histone deacetylase 3 by various extracellular and signal transduction pathways." Gene Expr 11(1): 13-21.

Hall, H. T., M. T. Wilhelm, et al. (2008). "RIP2 contributes to Nod signaling but is not essential for $\mathrm{T}$ cell proliferation, $\mathrm{T}$ helper differentiation or TLR responses." Eur J Immunol 38(1): 64-72.

Hasegawa, M., Y. Fujimoto, et al. (2008). "A critical role of RICK/RIP2 polyubiquitination in Nod-induced NF-kappaB activation." EMBO J 27(2): 37383. 
Hashimoto, Y., C. Zhang, et al. (2002). "An alternatively spliced isoform of transcriptional repressor ATF3 and its induction by stress stimuli." Nucleic Acids Res 30(11): 2398-406.

Inohara, N., L. del Peso, et al. (1998). "RICK, a novel protein kinase containing a caspase recruitment domain, interacts with CLARP and regulates CD95mediated apoptosis." J Biol Chem 273(20): 12296-300.

Inohara, N., T. Koseki, et al. (2000). "An induced proximity model for NF-kappa B activation in the Nod1/RICK and RIP signaling pathways." $\underline{\mathrm{J} \text { Biol Chem }}$ 275(36): 27823-31.

Kim, H. Y. and V. N. Gladyshev (2006). "Alternative first exon splicing regulates subcellular distribution of methionine sulfoxide reductases." BMC Mol Biol 7: 11.

Kim, J. W., E. J. Choi, et al. (2000). "Activation of death-inducing signaling complex (DISC) by pro-apoptotic C-terminal fragment of RIP." Oncogene 19(39): 44919.

Kobayashi, K., N. Inohara, et al. (2002). "RICK/Rip2/CARDIAK mediates signalling for receptors of the innate and adaptive immune systems." Nature 416(6877): 194-9.

Krieg, A., G. Le Negrate, et al. (2009). "RIP2-beta: a novel alternative mRNA splice variant of the receptor interacting protein kinase RIP2." Mol Immunol 46(6): 1163-70.

Li, H., M. Kobayashi, et al. (2006). "Ubiquitination of RIP is required for tumor necrosis factor alpha-induced NF-kappaB activation." J Biol Chem 281(19): $13636-43$.

Lin, Y., A. Devin, et al. (1999). "Cleavage of the death domain kinase RIP by caspase-8 prompts TNF-induced apoptosis." Genes Dev 13(19): 2514-26. 
Livak, K. J. and T. D. Schmittgen (2001). "Analysis of relative gene expression data using real-time quantitative PCR and the 2(-Delta Delta C(T)) Method." Methods 25(4): 402-8.

Mancini, U. and E. H. Tajara. "www.ncbi.nlm.gov/nuccore/45685662."

Martinon, F., N. Holler, et al. (2000). "Activation of a pro-apoptotic amplification loop through inhibition of NF-kappaB-dependent survival signals by caspasemediated inactivation of RIP." FEBS Lett 468(2-3): 134-6.

Matsuzaki, S., T. Manabe, et al. (2004). "Metals accelerate production of the aberrant splicing isoform of the presenilin-2." J Neurochem 88(6): 1345-51.

Meylan, E., F. Martinon, et al. (2002). "RIP4 (DIK/PKK), a novel member of the RIP kinase family, activates NF-kappa B and is processed during apoptosis." EMBO Rep 3(12): 1201-8.

Meylan, E. and J. Tschopp (2005). "The RIP kinases: crucial integrators of cellular stress." Trends Biochem Sci 30(3): 151-9.

Navas, T. A., D. T. Baldwin, et al. (1999). "RIP2 is a Raf1-activated mitogen-activated protein kinase kinase." J Biol Chem 274(47): 33684-90.

Nurmi, J. T., P. A. Puolakkainen, et al. (2005). "Intron 1 retaining cyclooxygenase 1 splice variant is induced by osmotic stress in human intestinal epithelial cells." Prostaglandins Leukot Essent Fatty Acids 73(5): 343-50.

O'Donnell, M. A., D. Legarda-Addison, et al. (2007). "Ubiquitination of RIP1 regulates an NF-kappaB-independent cell-death switch in TNF signaling." Curr Biol 17(5): 418-24.

Park, J. H., Y. G. Kim, et al. (2007). "RICK/RIP2 mediates innate immune responses induced through Nod1 and Nod2 but not TLRs." J Immunol 178(4): 2380-6. 
Perrier, N. A., M. Salani, et al. (2005). "The readthrough variant of acetylcholinesterase remains very minor after heat shock, organophosphate inhibition and stress, in cell culture and in vivo." J Neurochem 94(3): 629-38.

Shen, J., C. J. Beall, et al. (1993). "Tissue-specific alternative splicing of the Drosophila dopa decarboxylase gene is affected by heat shock." Mol Cell Biol 13(8): 454955.

Sun, X., J. Yin, et al. (2002). "Identification of a novel homotypic interaction motif required for the phosphorylation of receptor-interacting protein (RIP) by RIP3." J Biol Chem 277(11): 9505-11.

Takechi, H., N. Hosokawa, et al. (1994). "Alternative 5' splice site selection induced by heat shock." Mol Cell Biol 14(1): 567-75.

Thome, M., K. Hofmann, et al. (1998). "Identification of CARDIAK, a RIP-like kinase that associates with caspase-1." Curr Biol 8(15): 885-8.

Tomasini, R., A. A. Samir, et al. (2001). "Molecular and functional characterization of the stress-induced protein (SIP) gene and its two transcripts generated by alternative splicing. SIP induced by stress and promotes cell death." J Biol Chem 276(47): 44185-92.

Wakasugi, K., T. Nakano, et al. (2005). "Oxidative stress-responsive intracellular regulation specific for the angiostatic form of human tryptophanyl-tRNA synthetase." Biochemistry 44(1): 225-32.

Weil, D., M. D'Alessio, et al. (1989). "Temperature-dependent expression of a collagen splicing defect in the fibroblasts of a patient with Ehlers-Danlos syndrome type VII." J Biol Chem 264(28): 16804-9.

Wust, P., B. Hildebrandt, et al. (2002). "Hyperthermia in combined treatment of cancer." Lancet Oncol 3(8): 487-97.

www.ncbi.nlm.nih.gov. "www.ncbi.nlm.nih.gov." 
www.ncbi.nlm.nih.gov/BLAST/. "www.ncbi.nlm.nih.gov/BLAST/."

Yan, X., F. Xiu, et al. (2007). "Fever range temperature promotes TLR4 expression and signaling in dendritic cells." Life Sci 80(4): 307-13.

Yoo, J. and Y. J. Lee (2007). "Effect of hyperthermia on TRAIL-induced apoptotic death in human colon cancer cells: development of a novel strategy for regional therapy." J Cell Biochem 101(3): 619-30.

Zeng, Z., C. R. Sharpe, et al. (2006). "The expression and alternative splicing of alphaneurexins during Xenopus development." Int J Dev Biol 50(1): 39-46.

Zha, J., Q. Zhou, et al. (2004). "RIP5 is a RIP-homologous inducer of cell death." Biochem Biophys Res Commun 319(2): 298-303.

Zhang, S. Q., A. Kovalenko, et al. (2000). "Recruitment of the IKK signalosome to the p55 TNF receptor: RIP and A20 bind to NEMO (IKKgamma) upon receptor stimulation." Immunity 12(3): 301-11.

Zhao, W., H. An, et al. (2007). "Hyperthermia differentially regulates TLR4 and TLR2mediated innate immune response." Immunol Lett 108(2): 137-42. 